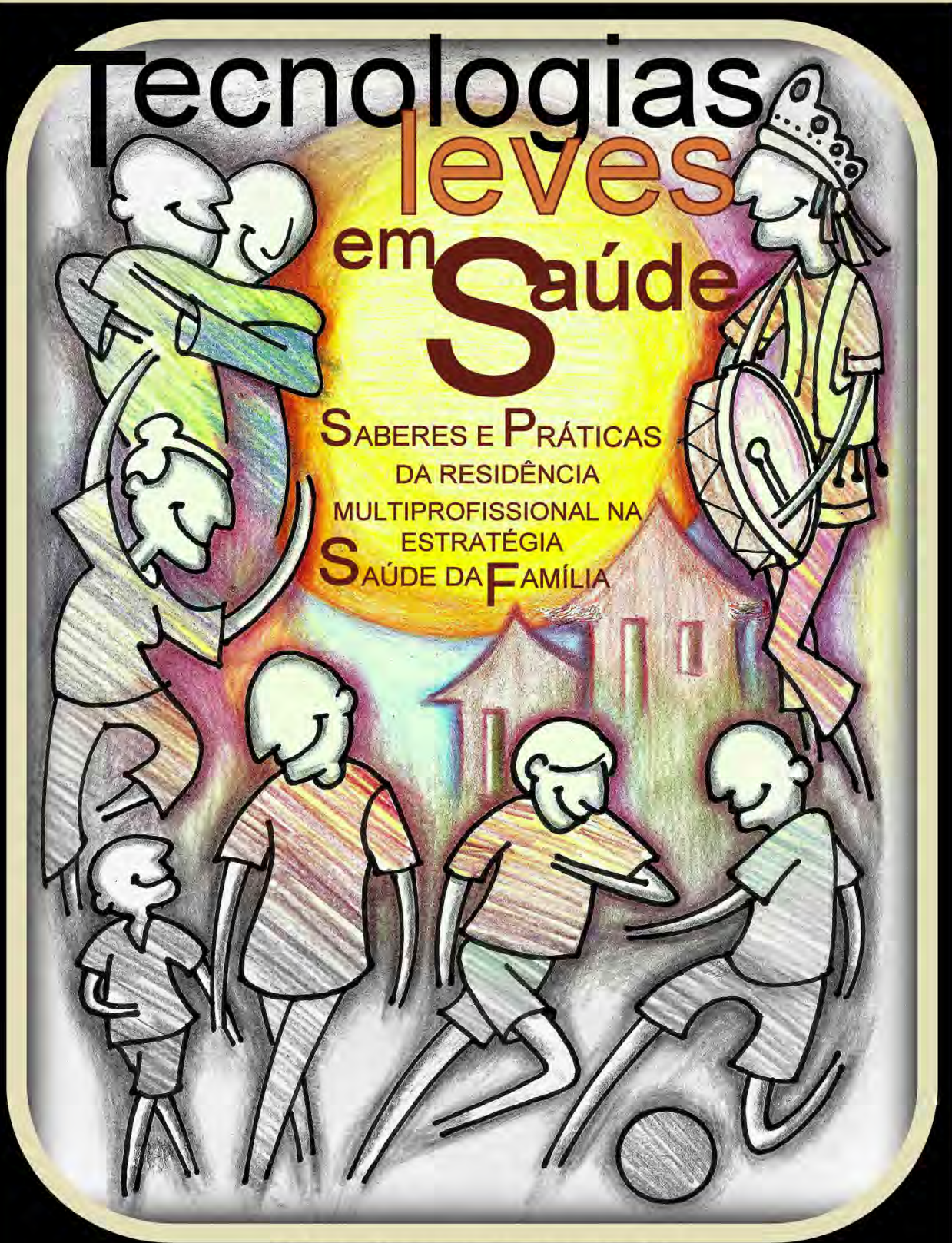

Maria Socorro de Araújo Dias Márcia Maria Santos da Silva Francisca Lopes de Souza Ana Karina de Sousa Gadelha Elyudienne Andressa Silva Alves ORGANIZADORAS

editora

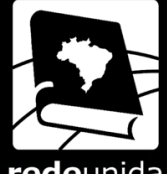




\section{Alcindo Antônio Ferla}

Coordenação Editorial

Alcindo Antonio Ferla

Conselho Editorial

Adriane Pires Batiston - Universidade Federal de Mato Grosso do Sul, Bras

Alcindo Antônio Ferla - Universidade Federal do Rio Grande do Sul, Brasil

Àngel Martínez-Hernáez - Universitat Rovira i Virgili, Espanha

Angelo Steffani - Universidade de Bolonha, Itália

Ardigó Martino - Universidade de Bolonha, Itália

Celia Beatriz Iriart - Universidade do Novo México, Estados Unidos da América

Dora Lucia Leidens Correa de Oliveira - Universidade Federal do Rio Grande do Sul, Brasil Emerson Elias Merhy - Universidade Federal do Rio de Janeiro, Brasil Izabella Barison Matos - Universidade Federal da Fronteira Sul, Brasil

João Henrique Lara do Amaral - Universidade Federal de Minas Gerais, Brasi Julio César Schweickardt - Fundação Oswaldo Cruz/Amazonas, Brasil

Laura Camargo Macruz Feuerwerker - Universidade de São Paulo, Brasil

Laura Serrant-Green - University of Wolverhampton, Inglaterra

Leonardo Federico - Universidade de Lanus, Argentina

Lisiane Böer Possa - Universidade Federal do Rio Grande do Sul, Brasil Liliana Santos - Universidade Federal da Bahia, Brasil

Mara Lisiane dos Santos - Universidade Federal de Mato Grosso do Sul, Brasil

Márcia Regina Cardoso Torres - Secretaria Municipal de Saúde do Rio de Janeiro, Brasil Marco Akerman - Universidade de São Paulo, Brasil

Maria Luiza Jaeger - Associação Brasileira da Rede UNIDA, Brasil

Maria Rocineide Ferreira da Silva - Universidade Estadual do Ceará, Brasil

Ricardo Burg Ceccim - Universidade Federal do Rio Grande do Sul, Brasil

Rossana Staevie Baduy - Universidade Estadual de Londrina, Brasil

Sueli Goi Barrios - Ministério da Saúde - Secretaria Municipal de Saúde de Santa Maria/RS, Brasi Túlio Batista Franco - Universidade Federal Fluminense, Brasil

Vanderléia Laodete Pulga - Universidade Federal da Fronteira Sul, Brasil

Vera Lucia Kodjaoglanian - Fundação Oswaldo Cruz/Pantanal, Brasil

Vera Rocha - Associação Brasileira da Rede UNIDA, Brasil

Comissão Executiva Editorial

Janaina Matheus Collar

João Beccon de Almeida Neto

Arte Gráfica - Capa

Martônio Holanda

Projeto Gráfico

Revisora de Língua Portuguesa

Silvana Regina Silva Vieira Arruda

Diagramação

Luciane de Almeida Collar

DADOS INTERNACIONAIS DE CATALOGAÇÃO NA PUBLICAÇÃO-CIP

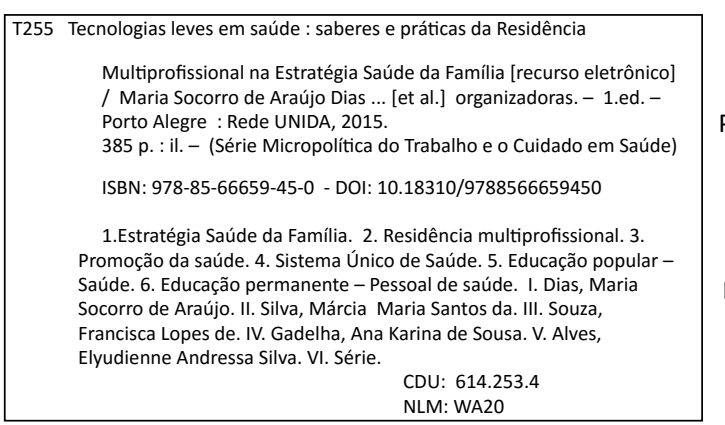

Grafia atualizada segundo o Acordo Ortográfico da Língua Portuguesa de 1990, que entrou em vigor no Brasil em 2009.

Copyright (C 2015 by Maria Socorro de Araújo Dias, Márcia Maria Santos da Silva, Francisca Lopes de Souza, Ana Karina de Sousa Gadelha e Elyudienne Andressa Silva Alves.

\section{Tecnologias Leves em Saúde: \\ Saberes e Práticas da Residência Multiprofissional na Estratégia Saúde da Família}

Maria Socorro de Araújo Dias

Márcia Maria Santos da Silva

Francisca Lopes de Souza

Ana Karina de Sousa Gadelha

Elyudienne Andressa Silva Alves

Organizadoras

NLM: WA2O 10.463

Todos os direitos desta edição reservados à Associação Brasileira Rede UNIDA

Rua São Manoel, no 498 - CEP 90620-110, Porto Alegre - RS Fone: (51) 3391-1252 www.redeunida.org.br 


\section{PREFÁCIO}

O presente livro é resultado de um trabalho produzido por coletivo(s) que foram se configurando no trabaIho em saúde. O município de Sobral vem acumulando, ao longo dos tempos, muitas reflexões sobre esse movimento que tem se revelado no campo do ensino no trabalho. 0 que ensinar? Como Ensinar? Quem são esses sujeitos, que estão nos territórios da Estratégia Saúde da Família? Que sentidos têm sido produzidos? Muitas respostas a essas questões, leitores e leitoras deste livro encontrarão. São trilhas singulares que, com escuta e esforço, foram sendo construídas.

A força das ações realizadas, reveladas na descrição de cada capítulo, vai nos mostrando que o caminho da educação permanente é potente para fortalecimento do Sistema Único de Saúde por fazer apostas nas transformações necessárias no(a) trabalhador(a) que está inserido num mundo que se produz pelos encontros de sujeitos a partir de agenciamentos realizados. É preciso investimento nas vidas que habitam a diversidade dessas trilhas.

Sim, um outro mundo é Possível! A Residência como experiência de formações nos ensina que o conhecimento que precisa ser produzido no mundo contemporâneo é aquele que nos garanta a produção de sentidos e de onde possamos garantir um mundo do trabalho com outras referências, que ao invés de excluírem, incluem. No 
campo da saúde, um dos aprendizados é que vivências nos territórios devem ser realizadas e que esses territórios são atravessados pelo vivido, pulsante e marcador das vidas. Os saberes são diversos e transitam entre aquilo que foi disciplinado, mas também no que cada um(a) traz consigo, fabricado a partir dos acontecimentos do que se vive, individual e coletivamente, em multiplicidade.

Sim, um outro mundo é Possível! Cada capítulo vai nos revelando que a formação precisa de diálogos em permanência nos campos da gestão, formação e participação popular, que a aprendizagem precisa fazer sentido para quem nela está envolvida e que isso é revelado com a mudança necessária nas práticas que precisam ser transformadas, a fim de garantir a integralidade da atenção com respostas às questões que se retratam cotidianamente. Como nos diz Freire, homens e mulheres aprendem mediatizados pelo mundo, visto que é dele que se extraem as perguntas com suas situações-limite e várias/diversas respostas, a partir das potencialidades que existem localmente para superação de muitas das situações encontradas.

Rachel de Queiroz, escritora cearense, tem uma expressão que nos apresenta bem o que encontramos ao realizar a leitura deste livro e é com essa expressão que convido você para realizar essa viagem de produção de saberes e práticas no mundo do trabalho na saúde: "Eu sou gente que se dói inteira porque não vive só na superfície das coisas". É assim que você vai sentir-se ao ler: aprendendo e ensinando em uma conversa sobre produções de outros modos de aprender, ensinar, cuidar, viver no mundo do trabalho em saúde que é atravessado pela educação.

Boa leitura! Múltiplas Vivências!

Profa. Dra. Maria Rocineide Ferreira da Silva Universidade Estadual do Ceará

\section{SUMÁRIO}

\section{APRESENTAÇÃO}

Maria Socorro de Araújo Dias, Márcia Maria Santos da Silva, Francisca Lopes de Souza, Ana Karina de Sousa Gadelha e Elyudienne Andressa Silva Alves.

\section{A PRODUÇÃO DE TECNOLOGIAS ENQUANTO EFETIVIDADE DA RESIDÊNCIA MULTIPROFISSIONAL EM SAÚDE DA FAMÍLIA \\ Márcia Maria Santos da Silva, Maria Socorro de Araújo Dias, Maria José Galdino Saraiva, Maria Rocineide Ferreira da Silva e Maristela Inês Osawa Vasconcelos. .13 \\ PARTICIPAÇÃO SOCIAL JUVENIL NA PROMOÇÃO DA SAÚDE NO TERRITÓRIO}

Ana Karina de Sousa Gadelha e Francisca Lopes de Souza 39

\section{O ESPORTE EDUCACIONAL COMO ESTRATÉGIA NA CULTURA DE PAZ}

Igor Carneiro Gomes, Léo Barbosa Nepomuceno e Bráulio Nogueira de Oliveira. .65

PRÁTICAS CORPORAIS E PROMOÇÃO DA SAÚDE EM UM GRUPO DE MULHERES DA ESTRATÉGIA SAÚDE DA FAMÍLIA Manoel Artur Ferreira Sousa Filho, Ana Helena Araújo Bomfim Queiroz, André Luis Façanha da Silva e Fátima Café Ribeiro dos Santos.. .91 
INSPIRE, EXPIRE E NÃO PIRE: GINÁSTICA LABORAL COMO PROMOTORA DE SAÚDE DOS TRABALHADORES DO SUS

Odemir Pires Cardoso Júnior e Maria Lidiany Tributino de Sousa...

EDUCAÇÃO POPULAR EM SAÚDE E PRÁTICAS CORPORAIS: CONTRIBUIÇÕES PARA O DEBATE

Bráulio Nogueira de Oliveira, Felipe Wachs, Igor Carneiro Gomes e Gláucia Almeidada Mapurunga de Paiva.

ENTRE MÃOS, GESTOS E OLHOS: A COMUNICAÇÃO ENTRE O ENFERMEIRO E O DEFICIENTE AUDITIVO NA ESTRATÉGIA SAÚDE DA FAMÍLIA

Danilo Sampaio Souza, Cilene Maria Freitas e André Luis Façanha da Silva......................................................................157

PUERICULTURA NA ATENÇÃO PRIMÁRIA EM SAÚDE: DESAFIOS NA ATUAÇÃO MULTIPROFISSIONAL

Janayna dos Santos Moura e Hermínia Maria Sousa da

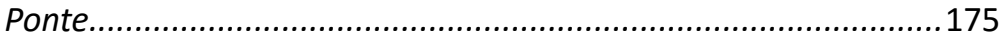

SAÚDE E ENVELHECIMENTO: A PERSPECTIVA DE IDOSOS PARTICIPANTES DE UM GRUPO DE CONVIVÊNCIA DA ESTRATÉGIA SAÚDE DA FAMÍLA

Elyudienne Andressa Silva Alves, Diana Cris Macedo Rodrigues, Carla Silvino de Oliveira e Israel Rocha Brandão.....

MUITO ALÉM DO PESO: REFLEXÕES SOBRE CORPO, OBESIDADE E SAÚDE EM MULHERES USUÁRIAS DA ESTRATÉGIA SAÚDE DA FAMÍLIA

Fátima Café Ribeiro dos Santos, Ana Helena Araújo Bomfim Queiroz e Manoel Artur Ferreira Sousa Filho...

VIOLÊNCIA DOMÉSTICA E SUAS INTERFACES COM AS QUESTÕES DE IDENTIDADE E GÊNERO

Maria da Glória dos Santos Ribeiro e Maria Michelle Bispo Cavalcante. .245
PRESERVANDO A VIDA DOS HOMENS: GRUPOS DE AUTOCUIDADO COM USUÁRIOS DE BEBIDA ALCOÓLICA

Gláucia Almeida Mapurunga de Paiva, Bráulio Nogueira de Oliveira e Adriano Ferreira Martins... .275

\section{ACOLHIMENTO INTERDISCIPLINAR EM SAÚDE MENTAL NA} ATENÇÃO PRIMÁRIA À SAÚDE

Maria das Graças Sousa e Maria Lidiany Tributino de Sousa.........293

PROMOÇÃO DE SAÚDE AMBIENTAL NA ESTRATÉGIA SAÚDE DA FAMÍLIA

Flávia Pinheiro da Costa, Márcio Anderson Cardozo Paresque e Adriano Ferreira Martins............................................................315

SATISFAÇÃO PROFISSIONAL DO AGENTE COMUNITÁRIO DE SAÚDE NA ESTRATÉGIA SAÚDE DA FAMÍLIA

Liduina Joyce Prado Linhares, Andréa Carvalho Araújo Moreira, Maria Michelle Bispo Cavalcante e Thamyrys Prado

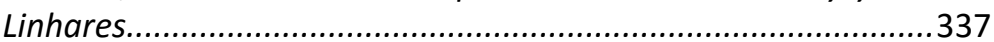

SISTEMA DE INFORMAÇÃO DA RESIDÊNCIA MULTIPROFISSIONAL (SIREMU): TECNOLOGIA PEDAGÓGICA E DE GESTÃO NA FORMAÇÃO MULTIPROFISSIONAL EM SAÚDE DA FAMÍLIA

Márcia Maria Santos da Silva, Maria Socorro de Araújo Dias, André Luis Façanha da Silva e Maristela Inês Osawa

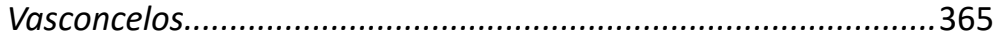

SOBRE OS AUTORES. .381 


\title{
APRESENTAÇÃO
}

\author{
"O que se opõe ao descuido e ao descaso \\ é o cuidado. Cuidar é mais que um ato; \\ é uma atitude. Portanto, abrange mais \\ que um momento de atenção. Representa \\ uma atitude de ocupação, preocupação, \\ de responsabilização e de envolvimento \\ afetivo com o outro." Leonardo Boff
}

Os programas de Residência Multiprofissional em Saúde (RMS) propõem a formação em serviço. Nesta, a educação conecta-se às práticas dos profissionais, potencializando-as, pelo meio do uso de metodologias ativas, participativas, dialógicas e a aprendizagem significativa como eixo pedagógico. Assim, as RMS devem operar a formação interdisciplinar, proporcionando, concomitantemente, o desenvolvimento dos núcleos específicos de saberes de cada área profissional e, também, o campo do cuidado comum a todas as profissões da saúde.

No município de Sobral, em 1999, foi criada a Residência Multiprofissional em Saúde da Família (RMSF), com o desafio de responder às necessidades do sistema local de saúde quanto à qualificação dos profissionais, a partir de um novo paradigma de saúde. A RMSF tem como referencial teórico-metodológico os princípios da Educação Permanente, Educação Popular e Educação por Competência, 
através dos quais busca desenvolver competências sociais, políticas, técnicas e humanas para as diversas categorias profissionais da Estratégia Saúde da Família. Ressaltamos nesse cenário, a construção de tecnologias em saúde, compreendidas como os processos de trabalho e intervenções realizadas nas práticas profissionais no SUS.

Ao longo desses 15 anos, a RMSF do município de Sobral tem contribuído significativamente, de modo instigador, de uma prática crítico-reflexiva sobre os avanços e desafios para a consolidação da ESF. Essas experiências no campo do ensino, da gestão, da atenção e do controle social têm impulsionado processos educacionais e de investigações produtoras de tecnologias leves em saúde.

Com o apoio da Secretaria da Saúde de Sobral (através da Escola de Formação em Saúde da Família Visconde de Sabóia), da Universidade Estadual Vale do Acaraú (UVA) e da Rede Unida, sistematizamos as experiências da IX turma de RMSF, em especial, aquelas sistematizadas nos Trabalhos de Conclusão, que apresentaram como foco de estudo as tecnologias desenvolvidas no contexto da Estratégia Saúde da Família. Esperamos que essa publicação contribua com a difusão de tais experiências e sinalize pistas na construção de conhecimentos e ressignificação de práticas no SUS.

As Organizadoras.

\title{
A PRODUÇÃO DE TECNOLOGIAS ENQUANTO EFETIVIDADE DA RESIDÊNCIA MULTIPROFISSIONAL EM SAÚDE DA FAMÍLIA
}

\author{
Márcia Maria Santos da Silva \\ Maria Socorro de Araújo Dias \\ Maria José Galdino Saraiva \\ Maria Rocineide Ferreira da Silva \\ Maristela Inês Osawa Vasconcelos
}

Introdução

O Sistema Único de Saúde (SUS), criado a partir da Constituição Brasileira de 1988 e regulamentado através da Lei 8.080/90, tem princípios defendidos pelo ideal do movimento de Reforma Sanitária e traz uma perspectiva de inovação no modelo de atenção à saúde. A reversão da lógica de assistência à saúde trata sobre a defesa do direito à saúde para todos os cidadãos; a integração das ações de saúde (preventivas e curativas) em um único sistema acessível a toda a população; a descentralização da gestão administrativa e financeira para estados e municípios; além da promoção da participação e controle pelos cidadãos nas ações de saúde. (BAPTISTA, 2007) A efetivação de mudanças nos modos de produção da atenção à saúde no 
Brasil tem exigido uma reorientação das práticas por parte dos trabalhadores do SUS, sendo esse um dos desafios que necessitam ser enfrentados pelos gestores do sistema de saúde e instituições formadoras.

$\mathrm{Na}$ busca de superação do cuidado, até então orientado por uma perspectiva eminentemente curativa e hospitalocêntrica, evidencia-se a necessidade da ressignificação dos processos de trabalho por parte dos profissionais de saúde, de forma que se tornem significativos para os trabalhadores e os impulsionem a vivenciar uma nova prática. É nesse contexto que as Residências Multiprofissionais ganham visibilidade, reconhecidas pela Portaria Interministerial no 45/2007 ${ }^{1}$, a qual determina que as residências em saúde sejam orientadas pelos princípios do SUS, a partir das necessidades e realidades locais e regionais.

Em Sobral/CE, a Residência Multiprofissional em Saúde da Família (RMSF) caracteriza-se pela imersão de profissionais egressos dos cursos de graduação na área da saúde, em sua maioria recém-formados na Estratégia Saúde da Família, com o objetivo de formar profissionais qualificados para o SUS, tendo em vista a compreensão de que os cursos de graduação ainda estão muito distantes dessa realidade. Além disso, coaduna com a necessidade de transformação de práticas e reorientação do modelo tecnoassistencial de atenção à saúde:

Promove não só o contato entre 0 mundo do trabalho e o mundo da formação, mas possibilita mudanças no modelo tecnoassistencial a partir da atuação multiprofissional ou integrada

${ }^{1}$ Portaria interministerial no 45, de 12 de janeiro de 2007: dispõe sobre a Residência Multiprofissional em Saúde e a Residência em Área Profissional da Saúde, e institui a Comissão Nacional de Residência Multiprofissional em Saúde. adequada às necessidades locorregionais, constituinte de um processo de Educação Permanente em Saúde. (CECCIM, 2010, p.20)

A residência multiprofissional em saúde, enquanto estratégia de mudança na formação dos trabalhadores da saúde, numa perspectiva interdisciplinar, foi idealizada para desencadear processos de formação ancorados na Educação Permanente com vistas à reorientação das lógicas tecnoassistenciais. A Educação Permanente, como prática de ensino-aprendizagem "(...) significa a produção de conhecimentos no cotidiano das instituições de saúde, a partir da realidade vivida pelos atores envolvidos, tendo os problemas enfrentados no dia a dia do trabalho e as experiências desses atores como base de educação e mudança." (CECCIM; FERLA, 2008, p.162)

A educação permanente em saúde vem contribuir com a superação de uma lacuna na formação dos profissionais que mantém um distanciamento das reflexões críticas sobre os modos de atenção à saúde. É exatamente nessa lacuna que se inserem os ideais do Quadrilátero da Formação para a Saúde, proposto por Ceccim e Feuerwerker (2004). Os autores apontam a existência de modelos formativos conservadores e estruturas de processos de trabalho que não convergem com a proposta de mudança do modelo trazida pelo SUS, inclusive quanto à participação popular. Sem deixar de valorizar a esfera técnica como um dos aspectos da qualificação, Ceccim e Feuerwerker (2004) propõem que a política de formação na saúde contemple os diversos atores que contribuem para uma postura crítica e de mudança na lógica programática das ações em saúde, quais sejam: gestores, profissionais, instituições formadoras e usuários dos serviços: 
Dessa reflexão nasceu, em 2003, o conceito de quadrilátero da formação: ensino - gestão - atenção - controle social. A qualidade da formação passa a resultar da apreciação de critérios de relevância para o desenvolvimento tecnoprofissional, o ordenamento da rede de atenção e a alteridade com os usuários. (CECCIM; FEUERWERKER, 2004, p.47)

A RMSF, enquanto estratégia de formação, mantém coerência com os pressupostos da Educação Permanente, favorecendo ainda, a articulação de atores preconizada no quadrilátero da formação em saúde.

No município de Sobral, região norte do Estado do Ceará, a RMSF é desenvolvida pela Escola de Formação em Saúde da Família Visconde de Sabóia (instituição formadora vinculada à Secretaria da Saúde do Município) em parceria com a Universidade Estadual Vale do Acaraú.

Compreendemos que os programas de residência, inclusive em virtude do significativo investimento por parte do Ministério da Saúde e de gestores locais, representam uma das estratégias potenciais para repensar o processo de formação em saúde. Em decorrência disso, evidencia-se a necessidade de que esses programas produzam resultados efetivos quanto à contribuição para a melhoria do fazer profissional no âmbito do SUS. Ao se pensar em resultados, é importante considerar que o programa de RMSF, pela essência da multidisciplinaridade e pela gama de possibilidades de atuação que favorece, caracteriza-se como um processo formativo de resultados que se manifestam em variadas esferas (técnica, humana, social, política, dentre outras).

A perspectiva de atuação docente e de gestão junto à RMSF possibilitou-nos a ampliação do olhar quanto aos processos formativos para o SUS, e trouxe-nos algumas inquietações, sobretudo quanto à efetividade dos resultados desse processo formativo, uma vez que nos foi possível acompanhar as discussões teóricas e suas interfaces com a realidade dos serviços de saúde. Efetividade é entendida por Mallet (2005, p.450) como "[...] a melhora alcançada, ou que se espera seja alcançada, em condições reais da prática diária."

Para fins deste estudo, entenderemos a efetividade como o efeito ou o impacto transformador, ou seja, capacidade de se promover resultados sobre uma realidade que se pretende modificar, apresentada pelos benefícios, efeitos ou impactos diretos ou indiretos. Consideraremos que a efetividade diz respeito à capacidade de se promover resultados pretendidos. (MARINHO; FAÇANHA, 2011) Entendemos, portanto, que a efetividade ou não da RMSF poderá ser identificada a partir de evidências relatadas e/ ou demonstradas pelo quadrilátero da formação na saúde.

Neste sentido, desdobrou-se o seguinte questionamento: Quais evidências são identificadas, em consonância com o quadrilátero da formação para a área da saúde, que expressam a efetividade da RMSF? Os dados e informações gerados com esse questionamento apontaram, dentre outros aspectos, a produção de tecnologias em saúde como uma das contribuições mais singulares da RMSF no município de Sobral.

A expressão "tecnologias" vem sendo utilizada no campo da saúde para designar a sistematização dos diversos modos de produzir saúde:

[...] a tecnologia deve ser compreendida como conjunto de ferramentas, entre elas as ações de trabalho, que põem em movimento uma ação transformadora da natureza. Sendo assim, além dos equipamentos, devem ser incluídos os 
conhecimentos e ações necessárias para operá-los: o saber e seus procedimentos. O sentido contemporâneo de tecnologia, portanto, diz respeito aos recursos materiais e imateriais dos atos técnicos e dos processos de trabalho, sem, contudo, fundir essas duas dimensões. (SCHRAIBER; MOTA; NOVAES, 2008, p.382)

Ancorado numa concepção marxista sobre o trabalho humano, em que se considera não somente sua dimensão operativa, mas enquanto práxis da relação homem/mundo, num processo de mútua produção, Merhy e Feuwerker (2009) refletem o trabalho em saúde como um trabalho vivo, permanente.

O trabalho vivo em ato é o trabalho criador, que possibilita a fabricação de um novo produto. O homem, no processo produtivo, pode utilizar com uma certa autonomia os elementos que já estão dados e esse autogoverno está marcado pela ação do seu trabalho vivo em ato sobre o que lhe é ofertado. (MERHY; FEUWERKER, 2009, p.03)

Nesta compreensão, Merhy (2005) considera que as tecnologias de produção do cuidado em saúde subdividemse em três categorias: as tecnologias leves, referentes a relações de produção de vínculo, acolhimento e gestão dos processos de trabalho; as tecnologias leve-duras, relacionadas aos saberes já estruturados, tais como a clínica médica e a epidemiologia; e as tecnologias duras, representadas pelos equipamentos tecnológicos, normas e estruturas organizacionais.

Concernente ao exposto, anunciamos como objetivo orientador deste estudo: analisar a produção de tecnologias em saúde enquanto efetividade da RMSF de Sobral/CE. Tomaremos como referência para tanto, o ideário do quadrilátero da formação para a área da saúde, para que essa análise contemple evidências de efetividade de tecnologias na RMSF sob o prisma da reorientação das práticas em saúde, na perspectiva de usuários, de profissionais da ESF, de gestores da saúde, de docentes e egressos da Residência.

\section{Metodologia}

Pesquisa do tipo exploratório-descritiva, de natureza qualitativa. Na concepção de Gil $(1996$, p.45) as pesquisas exploratórias "têm como objetivo proporcionar maior familiaridade com o problema, com vistas a torná-lo mais explícito ou a construir hipóteses. Pode-se dizer que estas pesquisas têm como objetivo principal o aprimoramento de ideias ou a descoberta de intuições".

Os pressupostos da abordagem qualitativa nortearam a análise do objeto, sendo que tomamos como referência neste estudo a concepção apresentada por Minayo (2012, p.21): "a pesquisa qualitativa trabalha com o universo de significados, motivos, aspirações, crenças, valores e atitudes [...] o que corresponde a um espaço mais profundo das relações, dos processos e dos fenômenos que não podem ser reduzidos à operacionalização de variáveis". No entanto, consideramos a possibilidade de articular eventuais dimensões quantitativas identificadas no decorrer da pesquisa, desde que elas contribuíssem na contextualização do objeto e colaborassem para a produção de evidências.

A abordagem utilizada no estudo, desenvolvido no período de Maio/2012 a Abril/2014, foi orientada pela Triangulação de Métodos proposta por Minayo (2006) e consistiu em uma alternativa de diálogo entre diferentes 
áreas do conhecimento, capaz de agregar distintos pontos de vista sobre um mesmo tema. O estudo adotou as seguintes estratégias metodológicas: o itinerário de consulta a documentos (entre eles, o Projeto Político-Pedagógico da RMSF, o Regimento Interno da RMSF e Relatórios do SIREMU), entrevista semiestruturada e grupo focal. O uso de cada técnica ocorreu conforme descrito no Quadro 1:

\section{Quadro 1 - Distribuição das Técnicas de Coleta de Dados por Sujeito/Objetos}

\begin{tabular}{|c|c|c|}
\hline COMPONENTE & SUJEITOS/ OBJETOS & TÉCNICA \\
\hline Ensino & $\begin{array}{l}\text { Tutor, preceptor e } \\
\text { egressos da RMSF }\end{array}$ & Entrevista \\
\hline Gestão & $\begin{array}{l}\text { Secretário de Saúde, } \\
\text { coordenador Atenção } \\
\text { Primária, gerentes dos } \\
\text { CSF, coordenador da } \\
\text { RMSF }\end{array}$ & Entrevista \\
\hline Atenção & Profissionais da ESF & Grupo Focal \\
\hline Controle Social & $\begin{array}{l}\text { Usuários dos territórios } \\
\text { de atuação da RMSF }\end{array}$ & Grupo Focal \\
\hline \multirow{3}{*}{$\begin{array}{c}\text { Transversal ao } \\
\text { Quadrilátero } \\
\text { para a } \\
\text { Formação na } \\
\text { área da Saúde }\end{array}$} & $\begin{array}{l}\text { Projeto Político- } \\
\text { Pedagógico }\end{array}$ & $\begin{array}{l}\text { Exame Analítico } \\
\text { de Documentos }\end{array}$ \\
\hline & Regimento Interno & $\begin{array}{l}\text { Exame Analítico } \\
\text { de Documentos }\end{array}$ \\
\hline & SIREMU & $\begin{array}{l}\text { Exame Analítico } \\
\text { de Documentos }\end{array}$ \\
\hline
\end{tabular}

Fonte: Elaborado pelas autoras, 2015.

Para a identificação dos sujeitos tomamos como referência a realização da 8a turma de Residência Multiprofissional em Saúde da Família em Sobral. No componente Ensino, optamos por considerar o olhar de docentes e discentes. Para a representação docente foram convidados 01 tutor e 01 preceptor. Como representação discente, convidamos 09 egressos da 8a turma de RMSF, sendo 01 de cada categoria profissional que compunha a referida turma. No componente Gestão, foram convidados a participar da pesquisa profissionais que atuassem ou tivessem atuado na gestão da RMSF ou de serviços da Atenção Primária à Saúde (APS) do município, os quais estivessem relacionados com a prática do residente multiprofissional em saúde da família. Quanto ao componente Atenção, convidamos 01 (um) profissional que atuasse em cada Centro de Saúde da Família que tenha sido campo de aprendizagem para residentes da $8^{a}$ turma de RMSF. Já o componente Controle Social, para fins de pesquisa, foi representado por moradores dos bairros, sendo 01 morador de cada bairro que se configurasse como área adscrita dos CSF em que os residentes tivessem atuado no período de 2010 a 2012, ou seja: 10 bairros.

No percurso de coleta das informações vimos a necessidade de organizá-las para que fossem, então, analisadas e interpretadas. Ao processo de organização das informações chamamos aqui de categorização, onde reconhecemos as informações, agregamos e as classificamos em categorias para análise. Para tanto, realizamos as seguintes etapas: 1) Transcrição das entrevistas e dos grupos focais; 2) Identificação das categorias; 3) Elaboração dos instrumentos de agrupamento; 4) Elaboração dos instrumentos de tematização; 5) Definição dos núcleos de sentidos; 6) Elaboração dos espelhos dos discursos.

Quanto aos dados colhidos em fontes documentais, a partir do roteiro previamente elaborado, identificamos as informações que mais se relacionavam ao objetivo do estudo e, ao passo que os Espelhos dos Discursos ${ }^{2}$ foram

$\overline{2}$ A denominação Espelhos dos Discursos foi utilizada pelas autoras para denominar quadros descritivos com os fragmentos de falas que 
sendo construídos, articulamos os recortes documentais que mais se aproximavam dos sentidos identificados.

A pesquisa foi orientada pelos preceitos da Resolução 466/12, de 12 de dezembro de 2012, do Conselho Nacional de Saúde, assegurando-se a premissa do respeito à dignidade humana, à participação livre e esclarecida dos sujeitos, à confidencialidade e à privacidade dos indivíduos, bem como o sigilo na utilização de informações institucionais referentes à pesquisa.

As categorias de análise foram identificadas a partir da categorização dos discursos dos sujeitos. Essas foram consideradas a partir do olhar de sujeitos que compõem o quadrilátero para a formação na área da saúde: docentes e egressos (Ensino); gestores do sistema de saúde e do Programa de Residência (Gestão); profissionais da Estratégia Saúde da Família (Atenção) e usuários (Controle Social).

\section{Análise e Discussão dos Resultados}

Dentre as categorias de análise identificadas na pesquisa, trazemos aqui os resultados referentes à produção de tecnologias na RMSF, evidenciados nos conjuntos de sentidos denominados Contribuições da RMSF e Evidências de Efetividade da RMSF. Os Conjuntos de Sentidos expressam o olhar dos quatro componentes que compõem o quadrilátero da formação para a área da saúde, quanto à efetividade da RMSF no município de Sobral, a partir dos discursos dos sujeitos e da análise de documentos referentes ao Programa de RMSF nesse mesmo município.
As Contribuições da Residência Multiprofissional em Saúde da Família

\section{Quadro 2 - Conjunto de Sentidos das Contribuições da RMSF}

\begin{tabular}{|l|l|}
\hline CONJUNTO DE SENTIDOS DAS CONTRIBUIÇÕES DA RMSF \\
\hline \multirow{4}{*}{ Núcleos de Sentido } & Produção de Tecnologias \\
\cline { 2 - 2 } & Novo Olhar \\
\cline { 2 - 2 } & Multiprofissionalidade \\
\cline { 2 - 2 } & $\begin{array}{l}\text { Potencialização da Educação } \\
\text { Permanente }\end{array}$ \\
\cline { 2 - 2 } & Politicidade \\
\hline
\end{tabular}

Fonte: Elaborado pelas autoras, 2015.

Nesse Conjunto de Sentidos verificamos nos discursos dos sujeitos a predominância de cinco contribuições que o programa de RMSF agrega ao sistema municipal de saúde: a Produção de Tecnologias; um Novo Olhar para a ESF, permeado de criticidade, estranhamento, pluralidade e inovação; a Multiprofissionalidade, expressa, sobretudo em ações coletivas e grupos; a Potencialização da Educação Permanente; e a Politicidade que emana nas expressões dos residentes nos espaços coletivos. Sobre estas contribuições, destacamos aqui a Produção de Tecnologias, sobre a qual teceremos algumas ideias, a partir do Espelho dos Discursos e do aporte teórico adotado na pesquisa.

subsidiaram a análise das informações. 


\begin{tabular}{|c|c|}
\hline \multicolumn{2}{|r|}{ PRODUÇÃO DE TECNOLOGIAS } \\
\hline & (Continuação) \\
\hline ENSINO & $\begin{array}{l}\text { Eu acho que a primeira coisa que ela pode } \\
\text { contribuir (...) é no sentido de buscar } \\
\text { desenvolver novas tecnologias para o Saúde } \\
\text { da Família a partir das categorias e a partir } \\
\text { das necessidades de saúde que existem, e a } \\
\text { partir das condições de trabalho que o Saúde } \\
\text { da Familia hoje nos coloca (E1) } \\
\text { Outra coisa que a Residência pode contribuir } \\
\text { bastante com o sistema, que é a questão } \\
\text { das tecnologias leves, as estratégias, os } \\
\text { grupos, sabe, a gente tem muita coisa legal, } \\
\text { interessante, ou sendo resgatada, ou sendo } \\
\text { criada. (E9) }\end{array}$ \\
\hline GESTÃO & $\begin{array}{l}\text { Mas eu entendo que a residência é muito um } \\
\text { espaço de laboratório, onde você oportuniza } \\
\text { um desenvolvimento de experiências e } \\
\text { práticas que de outro modo isso seria muito } \\
\text { pouco provável de acontecer. Então pra mim } \\
\text { uma das grandes contribuições da residência } \\
\text { é a questão dela operar nessa perspectiva de } \\
\text { construir o novo, a originalidade, a tendência... } \\
\text { (G2) }\end{array}$ \\
\hline ATENÇÃO & $\begin{array}{l}\text { E ela fica querendo envolver os agentes } \\
\text { de saúde. Chamando pra ajudar, pra ficar } \\
\text { também, participar. Eles, uma vez por mês, } \\
\text { eles tinham uma sexta-feira pra cuidar dos } \\
\text { agentes de saúde. (...) ali tinha relaxamento, } \\
\text { tinha conversa paralela, tinha massagem, } \\
\text { cuidando mesmo dos agentes de saúde. Eles se } \\
\text { juntavam, não era só um, não. Todos ficavam } \\
\text { na sala com a gente. Ali tinha dinâmica, era } \\
\text { muito bom. Era o "Cuidando do cuidador". (A2) }\end{array}$ \\
\hline
\end{tabular}

Porque nós se sentimos muito bem com a ginástica do lgor, ele deixou muita amizade. Quando ele saiu o pessoal ficou triste. É assim, ele chegava, nós se juntava com ele, CONTROLE na quadra, nós fazia atividade física, nós

SOCIAL caminhava, nós jogava bola, nós fazia exercício mesmo, foi muito bom. (...) Tinha gente que tinha problema de depressão, que até falava que depois que chegava no grupo, ai pronto. Melhorou total, sabe? (C1)

- Desenvolvimento de tecnologias para a ESF a partir das necessidades de saúde.

-A RMSF agrega a perspectiva de construir o novo, a tendência... Traz a originalidade.

A RMSF desenvolve tecnologias leves como os grupos com os usuários, e com profissionais (cuidando do cuidador).

Fonte: Elaborado pelas autoras, 2015.

A compreensão de que a RMSF vem incorporando ao sistema municipal de saúde, em especial à ESF, novas formas de produzir saúde, é comum aos quatro componentes do quadrilátero da formação para essa área, ainda que a denominação "tecnologias em saúde" não seja utilizada por todos os sujeitos da pesquisa. Essas "novas formas de produzir saúde" são cognominadas tecnologias de cuidado e são desenvolvidas a partir das necessidades identificadas. Neste sentido, a RMSF opera na perspectiva de construir o novo, de trazer inovações para as práticas em saúde.

A dimensão criativa, materializada pela postura de construir e desenvolver novas tecnologias, está prevista no Projeto Político-Pedagógico da $8^{a}$ turma de RMSF, que estabelece como principal objetivo do programa: 
Desenvolver tecnologias para a ESF, a partir da construção de competências teórico-metodológicas, técnicooperativas, sociais, políticas e humanas para as diversas categorias profissionais da saúde, de modo orgânico, participativo e alimentador da prática, na perspectiva da Promoção da Saúde, com vistas à transformação de práticas para a consolidação do SUS. (EFSFVS, 2010, p.18)

As tecnologias em saúde expressam novas formas de produzi-la. Ancoradas na criatividade, são desenvolvidas a partir de demandas da realidade e podem ser subdivididas em três categorias: leves, leve-duras e duras. (MERHY, 2005) A inserção da RMSF nos territórios, especialmente nos Centros de Saúde da Família, possibilita a interface das categorias tecnológicas leves e leve-duras.

Contudo, observamos que os discursos dos sujeitos apontam uma predominância no desenvolvimento de tecnologias aqui classificadas como "leves", quais sejam: os grupos, as ações de educação em saúde e os espaços de autocuidado para profissionais da ESF. A produção de tais tecnologias, tanto nos territórios da ESF, quanto nos espaços institucionais do programa, tem se tornado uma característica do Programa em Sobral.

Contemplado no discurso de todos os componentes, o desenvolvimento de tecnologias foi destacado pela Gestão como uma prática que confere à Residência a condição de "laboratório", na perspectiva de espaço onde a inventividade é fomentada de maneira propositiva para ampliar a gama de tecnologias do cuidado na ESF. A liberdade criativa da Residência foi ainda relacionada às condições de trabalho, uma vez que a sobrecarga de serviços ou mesmo condições de infraestrutura podem oferecer limitações ao desenvolvimento de novas práticas ou técnicas.
Ao incorporar a produção de tecnologias como foco prioritário a partir da formação de profissionais para atuar no SUS, a RMSF deixa transparecer sua opção pedagógica, bem como reafirma a propositura de transformação de práticas para fortalecimento da ESF. Assim, lança o desafio aos sujeitos do processo formativo, com ênfase nos discentes e docentes ${ }^{3}$ : "Entendemos que a consolidação da ESF como modelo de atenção primária do SUS está condicionada a inovações no que diz respeito ao modo de pensar, ser e agir dos profissionais da saúde que atuam na atenção primária." (EFSFVS, 2010 p.25)

Do ponto de vista do componente Ensino, a produção detecnologias na Residência ocorre a partir das necessidades de saúde dos territórios, seja na ótica de criar ou de resgatar algo já deflagrado anteriormente, conferindo à Residência ora um papel protagonista, ora de coadjuvante no desenvolvimento de tecnologias de cuidado nos territórios de atuação. Merhy e Feuerwerck registram que "é nesse território que se produzem os encontros e a possibilidade de uma construção efetivamente negociada." (MERHY; FEUERWERCK, 2009, p.10) Logo, o compromisso com demandas locais deve estar alicerçado nas compreensões de vínculo, de determinantes sociais da saúde, bem como numa postura ética que inclua, sobretudo, o cuidado com a vida.

Vimos, então, que a produção de tecnologias vem sendo apontada como um diferencial trazido pela inserção da RMSF na ESF, o que requer aproximação com o território, curiosidade e criatividade quanto a outras possibilidades de cuidado ao se deparar com determinadas situações, com vistas a inovar ou transformar práticas na ESF.

${ }^{3}$ Compreendemos como sujeitos do processo formativo os docentes, os discentes, os gestores, trabalhadores do SUS, usuários dos serviços e todos os parceiros (inclusive intersetoriais) que contribuem para o desenvolvimento da RMSF. 


\section{As Evidências de Efetividade}

\section{Quadro 4 - Conjunto de Sentidos das Evidências de Efetividade}

\begin{tabular}{|l|l|}
\hline \multicolumn{2}{|c|}{ CONJUNTO DE SENTIDOS DAS EVIDÊNCIAS DE EFETIVIDADE } \\
\hline \multirow{4}{*}{ Núcleos de Sentido } & Produção de Tecnologias \\
\cline { 2 - 2 } & Grupos \\
\cline { 2 - 2 } & Reorganização das Práticas em Saúde \\
\cline { 2 - 2 } & $\begin{array}{l}\text { Fortalecimento da Participação } \\
\text { Social }\end{array}$ \\
\hline
\end{tabular}

Fonte: Elaborado pelas autoras, 2015.

Este Conjunto de Sentidos apresenta as evidências de efetividade apontadas pelos sujeitos da pesquisa. Consideramos o ápice do estudo, pois aponta a convergência dos discursos quanto ao cerne do objeto em análise.

Para fins desse estudo, consideramos efetividade como a capacidade de se promover resultados pretendidos, a qual pode ser apresentada pelos benefícios, efeitos ou impactos diretos ou indiretos promovidos. Portanto, exporemos os elementos que, na ótica do quadrilátero da formação para a área da saúde, representam a efetividade da RMSF no município de Sobral.

Nesse Conjunto de Sentidos, porém, não pretendemos iniciar novas discussões teóricas, apenas revisitar alguns conceitos anteriores, de forma a possibilitar um espaço eminente de socialização de evidências, que nos permita vislumbrar aspectos intrínsecos à realidade vivenciada pela Residência na ESF em Sobral. Por isso, iremos favorecer um intenso "mergulho na realidade" por meio dos sentidos de efetividade de: tecnologias, grupalidade, reorganização de práticas e fortalecimento à participação social, nesse Conjunto de Sentidos, do qual destacamos o Sentido da Efetividade de Tecnologias.

\section{Quadro 5 - Espelho dos Discursos - Evidências de} Efetividade

\begin{tabular}{|c|c|}
\hline \multicolumn{2}{|r|}{ Produção de Tecnologias } \\
\hline & (Continuação) \\
\hline ENSINO & $\begin{array}{l}\text { A produção dessastecnologias comoo SIREMU, } \\
\text { como o acolhimento em saúde mental, que já } \\
\text { foi implantado em outros territórios dentro } \\
\text { do município e já foi levado para outros } \\
\text { programas de Residência fora do município, } \\
\text { devido às vivências de extensão. (E4) } \\
\text { Teve a construção do projeto Academia da } \\
\text { Saúde, que foi outra política lançada pelo } \\
\text { Ministério da Saúde especificamente de } 2011 \\
\text { pra cá. Então, com o apoio dos residentes, (...) } \\
\text { a gente começou a desenhar essa proposta, } \\
\text { como éque seria essa Academia da Saúde. (E1) } \\
\text { o perfil profissional; criação dessas novas } \\
\text { tecnologias. Eu vejo que criam-se estratégias } \\
\text { que não estão necessariamente protocoladas } \\
\text { pelo MS, aquela coisa que vem de cima para } \\
\text { baixo... Não, aqui mesmo criam-se soluçães, } \\
\text { criam-se formas de contato interdisciplinar, } \\
\text { que é uma coisa difícil. Geralmente é cada um } \\
\text { encaminhando para o outro, separadamente. } \\
\text { E eu vi na Residência essas estratégias } \\
\text { interdisciplinares. (E10) }\end{array}$ \\
\hline
\end{tabular}




\section{Quadro 5 - Espelho dos Discursos - Evidências de Efetividade}

\begin{tabular}{|c|c|}
\hline & Produção de Tecnologias \\
\hline GESTÃO & $\begin{array}{l}\text { A ideia, como já falei aqui, do desenvolvimento } \\
\text { de tecnologias no contexto da saúde, eu } \\
\text { acho que isso é uma importante evidência. } \\
\text { Aqui mesmo a gente tem o SIREMU, mas } \\
\text { assim, o próprio Projeto Político-Pedagógico } \\
\text { da Residência, a proposta, o desenho da } \\
\text { Residência, que é um desenho extremamente } \\
\text { original e que se diferencia muito dos } \\
\text { programas tradicionais de formação. (G2) } \\
\text { Incorporação de estratégias, eu vou recuperar } \\
\text { um pouco do que eu já disse né, a incorporação } \\
\text { de metodologias, de tecnologias leves no } \\
\text { processo de trabalho da ESF (...) a ampliação } \\
\text { do acesso considerando as diferentes formas } \\
\text { do cuidar e aí talvez já como produto da } \\
\text { incorporação de novas tecnologias e a } \\
\text { contribuição para o fortalecimento do sistema } \\
\text { Saúde Escola. (G3) }\end{array}$ \\
\hline ATENÇÃO & $\begin{array}{l}\text { Inclusive teve esse trabalho de saúde mental } \\
\text { que foi começado por uma residente. Foi ela } \\
\text { que começou com essa preocupação, dessas } \\
\text { pessoas que estavam tomando remédio } \\
\text { controlado e a gente foi achando que alguma } \\
\text { coisa tinha de errada. (...) E aí foi quando ela } \\
\text { tomou essa atitude e disse: "Gente, vamos } \\
\text { fazer um trabalho", e juntou nós ACS e os } \\
\text { residentes. (...) E aí foi feito um levantamento. } \\
\text { Eu fui chamando pessoa por pessoa pra saber } \\
\text { qual era a causa. Daí a gente foi fazendo um } \\
\text { diagnóstico, passando para a médica, pra } \\
\text { ver se tinha necessidade ou não. Eu sei que } \\
\text { diminuiu. Hoje nós temos pessoas tomando } \\
\text { remédio controlado, mas não é mais por conta } \\
\text { de depressão. É por uma dor. (A4) }\end{array}$ \\
\hline
\end{tabular}

(Conclusão)

\begin{tabular}{|c|l|}
\hline CONTROLE & $\begin{array}{l}\text { Por que nós se sentimos muito bem com a } \\
\text { ginástica do Igor, ele deixou muita amizade. } \\
\text { Quando ele saiu o pessoal ficou triste. É } \\
\text { assim, ele chegava, nós se juntava com ele, } \\
\text { na quadra, nós fazia atividade física, nós } \\
\text { caminhava, nós jogava bola, nós fazia exercício } \\
\text { mesmo, foi muito bom. (...) Tinha gente que } \\
\text { tinha problema de depressão, que até falava } \\
\text { que depois que chegava no grupo, aí pronto. } \\
\text { Melhorou total, sabe? (C1) }\end{array}$ \\
\hline SÍNTESE & $\begin{array}{l}\text { Observa-se a produção de tecnologias leves } \\
\text { e leve-duras pela RMSF. } \\
\text { - Alguns resultados } \\
\text { desenvolvimento do Sistema de Informação } \\
\text { da Residência Multiprofissional em } \\
\text { Saúde; Projetos Político-Pedagógicos das } \\
\text { Residências Multiprofissionais de Sobral; } \\
\text { Projeto Academia da Saúde. } \\
\text { A RMSF contribui para a ampliação do acesso } \\
\text { ao sistema de saúde, considerando as diversas } \\
\text { formas de cuidar que desenvolve. }\end{array}$ \\
\hline
\end{tabular}

Fonte: Elaborado pelas autoras, 2015.

Na RMSF a produção de tecnologias foi apontada como uma evidência de efetividade do Programa, contemplada no discurso dos quatro componentes do quadrilátero da formação para a saúde. As tecnologias apontadas nos discursos foram:

- Acolhimento em Saúde Mental no CSF UVA

Trata-se de uma estratégia de acolhimento diferenciado às pessoas em situação de sofrimento mental no território do CSF UVA. A proposta foi idealizada por uma 
residente da categoria de Enfermagem no ano de 2009, a qual mobilizou agentes comunitários de saúde, residentes, médicos e outros enfermeiros da equipe. Os profissionais atuaram de maneira compartilhada, tanto na busca quanto na implantação de estratégias de enfrentamento ao problema. Atualmente a estratégia permanece, inclusive sendo disseminada para outros territórios.

\section{- Grupos de Práticas Corporais}

São espaços coletivos de cuidado, onde são desenvolvidas atividades corporais, geralmente de modo interdisciplinar. Tais grupos, além de atividades físicas em si, fomentam o autocuidado por parte da comunidade e favorecem a criação de vínculo - tanto dos participantes entre si quanto destes com os residentes. Observa-se, em alguns casos, uma articulação com os profissionais do NASF para a realização de tais atividades.

\section{- Projeto Político-Pedagógico da RMSF}

É a sistematização escrita da proposta formativa da Residência Multiprofissional em Saúde da Família no município. Seu caráter diferenciado vem sendo reconhecido por outros programas, conforme temos verificado em experiências de intercâmbio vivenciadas pelos residentes. O PPP da RMSF é inacabado, pois a cada turma é reformulado em algum aspecto, sempre com vistas a melhor adequação à realidade local, a partir do feedback interno (discentes e docentes) e externo (CSF, instituições parceiras, comunidade).

\section{- Projeto Academia da Saúde}

O Programa Academia da Saúde foi implantado pelo Ministério da Saúde em 2011 e visa contribuir para a promoção da saúde da população a partir da implantação de espaços públicos que ofertem infraestrutura, equipamentos e profissionais qualificados. A contribuição da RMSF concretizou-se na elaboração de projeto local para participar do processo de seleção aberto para os municípios, sendo Sobral contemplado com a implantação de três academias da saúde.

- Sistema de Informação da Residência Multiprofissional em Saúde da Família (SIREMU)

É um sistema de informação que se configura como um conjunto de dados originados das ações desenvolvidas pelos residentes, organizados de maneira informatizada, para subsidiar a elaboração de indicadores de monitoramento e avaliação de processo e resultados, como uma tecnologia de gestão e de educação na Residência. (SILVA et al., 2012) O SIREMU é uma tecnologia de caráter extremamente inovador, tendo sido reconhecido nacionalmente este aspecto em 2014, com a premiação em 1 ㅇ lugar no Concurso InovaSUS 4 .

A partir das tecnologias mencionadas nos discursos, podemos inferir que a RMSF tem produzido tecnologias leves e tecnologias leve-duras, as quais direta ou indiretamente contribuem para o crescimento do sistema local de saúde. Acreditamos que a Proposta Pedagógica da Residência (considerando o referencial teórico, a dialogicidade presente e a busca pela efetivação da práxis) é a mola propulsora na abertura para a produção de tais tecnologias. Contudo, percebemos uma predominância na produção de tecnologias leves quando constatamos a incidência de muitos grupos no fazer cotidiano dos residentes (os quais certamente favorecem a ampliação do acesso ao sistema de saúde).

${ }^{4}$ InovaSUS é um concurso para premiação nacional de experiências no SUS, com os objetivos de identificar, valorizar e premiar experiências inovadoras implementadas pelas esferas municipais e estaduais. 


\section{Considerações Finais}

A opção por uma pesquisa sobre a RMSF em Sobral representa uma reflexão sobre um processo formativo que pretende agregar saberes e transformar práticas, a partir de iniciativas inovadoras na ESF: que evidências apontam os protagonismos, os conhecimentos e as transformações possíveis neste cenário?

Os resultados da pesquisa revelam que a produção de tecnologias do cuidado emerge como um diferencial da RMSF no município. A criatividade, a ousadia e o olhar inovador são marcas que a Residência Multiprofissional tem agregado nos territórios onde está inserida. Vimos que tecnologias leves e leve-duras vêm sendo desenvolvidas. Superar os limites institucionais, conciliar a crescente demanda por ações de caráter clínico e suscitar outra visão do processo saúde-doença (com enfoque na promoção de hábitos saudáveis, de vida saudável) não é uma tarefa simples. O choque entre essa realidade e as reflexões entrelaçadas nos momentos teórico-práticos da Residência figura como a mola propulsora para a busca de novas estratégias de cuidado.

Após elencarmos os aspectos mais intrínsecos ao Programa, e refletirmos sobre as contribuições apontadas pelos quatro componentes do quadrilátero da formação para a saúde, verificamos que a RMSF contribui para a ampliação do acesso aos serviços de saúde, considerando as diversas formas de cuidar que desenvolve. As tecnologias efetivadas na ESF, com a ESF e para a ESF, são fomentadas a partir das necessidades de saúde identificadas nos territórios. Assim, verificamos que a RMSF atua na perspectiva de construir o novo, originando novas tecnologias de cuidado. Contudo, observamos uma fragilidade no que concerne à sistematização de tais experiências, de forma a disseminálas e aprimorá-las.
O desafio proposto na RMSF vai além de formar profissionais; a pretensão é formar (ou transformar) sujeitos de um processo social onde práticas de saúde precisam ser constantemente revisitadas. Considerando isso, uma inquietação que emerge é quanto ao alcance que esse processo formativo pode ter (em termos de aprendizagem, de produção de tecnologias em saúde e de transformações que pode suscitar nos serviços de saúde).

Neste sentido, compreendemos que o presente estudo trilhou um longo e reflexivo caminho, mas que há ainda muito a ser percorrido. Não intencionamos esgotar aqui o aprendizado, tampouco as reflexões. Ensejamos que o presente estudo amplie o banco de pesquisas sobre a temática, instigue novos estudos e contribua para que a RMSF efetivamente consiga levar os profissionais a vivenciar uma nova práxis e desenvolver novas formas de cuidar.

\section{Referências}

BAPTISTA, T.V. História das Políticas de Saúde no Brasil: a trajetória do direito à saúde. In: MATTA, G.C.; PONTES, A.L.M. (Org.). Políticas de saúde: a organização e operacionalização do Sistema Único de Saúde. Rio de Janeiro: EPSJV/Fiocruz, 2007.

CECCIM, R.B.; FEUERWERKER, L.C.M. O quadrilátero da formação para a saúde: ensino, gestão, atenção e controle social. In: Physis. Rio de Janeiro, v.14 n.1, p.41-65. jan./ jun. 2004.

CECCIM, R.B.; FERLA, A.A. Educação Permanente em Saúde. In: PEREIRA, I.B.; LIMA, J.C.F. Dicionário da Educação Profissional em Saúde. Rio de Janeiro: EPSJV, 2008. p.162168 
CECCIM, R.B. Residências em saúde: as muitas faces de uma especialização em área profissional integrada ao SUS. In: BRASIL. Ministério da Saúde. Grupo Hospitalar Conceição. Residências em saúde: fazeres $\&$ saberes na formação em saúde. Organização de Ananyr Porto Fajardo, Cristianne Maria Famer Rocha, Vera Lúcia Pasini. Porto Alegre: Hospital Nossa Senhora da Conceição, 2010.

EFSFVS. Projeto Político Pedagógico da RMSF. Sobral, 2010.

GIL, A.C. Como elaborar projetos de pesquisa. São Paulo: Atlas, 1996.

MALLET, A.L.R. Qualidade em Saúde: tópicos para discussão. Revista da SOCERJ. Rio de Janeiro, p. 449-456. set/out. 2005.

MARINHO, A.; FAÇANHA, L.O. Programas Sociais: efetividade, eficiência e eficácia como dimensões operacionais da avaliação. IPEA, 2001.

MERHY, E.E. Saúde: a cartografia do trabalho vivo. São Paulo: Hucitec, 2005.

MERHY, E.E.; FEUERWERKER, L.C.M. Novo olhar sobre as tecnologias de saúde: uma necessidade contemporânea. In: MANDARINO, A.C.S.; GOMBERG, E. (Orgs.). Leituras de novas tecnologias e saúde. São Cristóvão: Editora UFS, 2009. p.29-74.

MINAYO, M.C.S. O desafio do conhecimento: pesquisa qualitativa em saúde. São Paulo: Hucitec, 2006.

Pesquisa social: teoria, método e criatividade. Petrópolis: Vozes, 2012.

SCHRAIBER, L.B.; MOTA, A.; NOVAES, H.M.D. Tecnologias em saúde. In: PEREIRA, I.B. Dicionário da educação profissional em saúde. 2.ed. rev./ ampl. Rio de Janeiro: EPSJV, 2008.
SILVA, A.L.F.; CARVALHO, W.R.L.; SANTOS, L.R.; SOUZA, F.L.; CHAGAS, M.I.O. Sistema de Informação da Residência Multiprofissional em Saúde da Família de Sobral-CE: em busca de indicadores de efetividade dos programas de formação em serviço. In: FALCÃO SOBRINHO, J.; BRANDÃO, I.R.; CHAGAS, M.I.O. Semiárido: Estado, Políticas Públicas e Saúde. Coleção Mossoroense, Edições Universitárias, 2012. 


\title{
PARTICIPAÇÃO SOCIAL JUVENIL NA PROMOÇÃO DA SAÚDE NO TERRITÓRIO
}

\author{
Ana Karina de Sousa Gadelha
} Francisca Lopes de Souza

\section{Introdução}

O Sistema Único de Saúde (SUS) surgiu como produto da reforma sanitária brasileira, originada do movimento sanitário, processo político que mobilizou a sociedade brasileira a propor novas políticas e novos modelos de organização de sistemas, serviços e práticas de saúde. Vasconcelos e Pache (2009) o consideram um arranjo organizacional do Estado que dá suporte à efetivação das políticas de saúde do país.

A regulamentação do SUS ocorreu pela Constituição Federal de 1988, pelas Leis Federais no 8.080 e 8.142 de 1990 , pelas legislações estaduais e municipais, e pelas normas operacionais nas três esferas do governo. A partir dessa regulamentação foram estabelecidos os princípios e diretrizes, bem como seus objetivos, atribuições e competências, sua abrangência, seu financiamento e as orientações detalhadas da operacionalização da política de saúde. 
No que tange à participação social, a lei 8.142/90 dispõe sobre a participação da comunidade na gestão do SUS, através de instâncias de deliberação e discussão nas três esferas de governo, com distribuição paritária entre trabalhadores, gestores e usuários. Essas instâncias são os Conselhos e Conferências de Saúde, que tanto são propositores de estratégias de controle e execução como avaliam e sugerem mudanças nas políticas de saúde. (BRASIL. PRESIDÊNCIA DA REPÚBLICA, 1990)

A participação social é a forma de assegurar a garantia dos direitos dos cidadãos e os espaços de decisão popular. Nesses espaços, os sujeitos influenciam e são influenciados a tomar decisões importantes dentro de um contexto sociocultural. Conforme Escorel (2008), a participação social é conceituada como:

\begin{abstract}
Um conjunto de relações culturais, sociopolíticas e econômicas em que os sujeitos, individuais ou coletivos, diretamente ou por meio de seus representantes, direcionam seus objetivos para o ciclo de políticas públicas, procurando participar ativamente da formulação, implementação, implantação, execução, avaliação e discussão orçamentária das ações, programas e estratégias que regulam a distribuição dos bens públicos e, por isso, interferem diretamente nos direitos de cada cidadão. (ESCOREL, 2008, p.986)
\end{abstract}

Contudo, é possível vislumbrar formas de participação de maneira dialogada e não necessariamente institucionalizada, uma vez que os espaços de participação estão para além das instituições formais de controle social. Dentro desses espaços existem condições favoráveis para trocas de conhecimento e compartilhamento de informações de interesse comum. Trata-se de um processo de luta por direitos e cidadania que está fortemente ligado ao diálogo libertador, que preconiza uma transformação cultural, em que a pessoa passa a se ver como sujeito ativo e social, capaz de problematizar e modificar sua própria realidade. (SORATTO; WITT, 2010) Nesse sentido, a problematização através do diálogo visa gerar mais autonomia e criticidade nos sujeitos, tornando-os protagonistas de suas próprias vidas através da compreensão da sua história, dos seus valores, da política e da cultura, promovendo assim, uma releitura da realidade e a implementação de ações concretas na direção da mudança.

Partindo do conceito mais ampliado de saúde, que leva em conta a melhoria da qualidade de vida dentro de um contexto sócio-histórico e político-cultural, considerando os determinantes sociais de saúde e a participação social, chega-se ao conceito de promoção da saúde.

Propõe-se, então, que as intervenções em saúde ampliem seu escopo, tomando como objeto os problemas e as necessidades de saúde, além de seus determinantes e condicionantes, de modo que a organização da atenção e do cuidado envolva, ao mesmo tempo, as ações e os serviços que operem sobre os efeitos do adoecer e aqueles que visem ao espaço para além dos muros das unidades de saúde e do sistema de saúde, incidindo sobre as condições de vida e favorecendo a ampliação de escolhas saudáveis por parte dos sujeitos e das coletividades no território onde vivem e trabalham. (BRASIL. MINISTÉRIO DA SAÚDE. SECRETARIA DE VIGILÂNCIA EM SAÚDE. SECRETARIA DE ATENÇÃO À SAÚDE, 2010)

Ressalta-seaimportância de uma corresponsabilização da saúde, por parte dos gestores, trabalhadores e usuários, segundo a qual haja um compromisso ético-político, além da construção e gestão de políticas de saúde compartilhadas, 
que se direcionem para formas de viver mais saudáveis. Nesse compartilhamento de responsabilidades faz-se necessário o envolvimento também de outros setores, uma vez que a promoção da saúde extrapola o setor saúde ao apresentar-se como proposta de cidadania e de garantia de direitos da pessoa humana.

As políticas públicas de juventude, bastante recentes no país, também enfatizam a importância da intersetorialidade, uma vez que o público jovem representa uma parcela considerável da população economicamente ativa e portadora de direitos e cidadania. (BRASIL. SECRETARIA NACIONAL DE JUVENTUDE, 2013b) Conforme classificação de faixa etária jovem, estabelecida pelo Conselho Nacional de Juventude - Conjuve na Cartilha de Políticas Públicas e Juventude da Secretaria Nacional de Juventude (BRASIL. SECRETARIA NACIONAL DE JUVENTUDE, 2013b), consideram-se jovens pessoas com idade entre 15 e 29 anos.

Para além da classificação a partir de faixa etária, Novaes e Vital (2005) apresentam o conceito de juventude na sociedade moderna como "um tempo de construção de identidades e de definição de projetos de futuro". Elas também enfatizam a existência de "juventudes", pois existem inúmeras formas de viver esse período de transição. Trata-se de um conceito dinâmico no tempo e no espaço, mas que apresenta singularidades, uma vez que toda experiência intergeracional é única.

As experiências intergeracionais e o cenário político em que o jovem está inserido influenciam nas formas diferentes de participação juvenil ao longo da História. Novaes e Vital (2005) apresentam essas diferenças e ressaltam características das "juventudes" variando conforme o tempo e organização societária, sugerindo a emergência de uma nova forma de participação política juvenil nos últimos anos, em que os objetivos e formas são diversos e não necessariamente vinculados a instituições ou partidos políticos.

É importante ainda ressaltar o conceito de território, pois trata do lócus onde a participação social acontece de fato. Esse espaço possui múltiplos significados, por ser dinâmico e complexo de interações onde a vida em comunidade acontece. (MONKEN et al. apud PONTE et al., 2010) compreendem território como uma base para a organização dos serviços, considerando o contexto saúdedoença e bem-estar da população e os vínculos desta com os profissionais de saúde. Na Estratégia Saúde da Família, os territórios são divididos com o objetivo de organizar o serviço e atender uma determinada clientela adscrita àquela área. Entretanto, levam-se em conta as interações sociais e o contexto comunitário, requerendo constante (re) territorialização por parte da equipe, a fim de inserir-se na dinâmica local e otimizar ações. Além disso, a compreensão de território para os moradores também é bastante relativa por abranger as diferentes formas de interagir e viver aquele espaço.

Para fins desta pesquisa, foram utilizados todos esses conceitos prévios, pois o objetivo principal era investigar o impacto da participação social dos jovens moradores de um bairro de Sobral-CE, na promoção da saúde no território, considerando o protagonismo no grupo Projovem Adolescente e a participação dos jovens no Conselho Local de Saúde e Desenvolvimento Social (CLDSS) do bairro.

\section{Aproximando a Temática}

Conforme o Ministério do Desenvolvimento Social e Combate à Fome (BRASIL. MINISTÉRIO DO DESENVOLVIMENTO SOCIAL E COMBATE À FOME. 
ASSISTÊNCIA SOCIAL. PROTEÇÃO BÁSICA, 2013a), o Projovem Adolescente era um Serviço de Convivência e Fortalecimento de Vínculos (SCFV) para adolescentes de 15 a 17 anos, frequentadores da escola, com famílias beneficiárias do Programa Bolsa Família ou em situação de risco pessoal e social, encaminhados pelos serviços de proteção social. Os grupos eram constituídos por cerca de 30 participantes que desenvolviam atividades promotoras de fortalecimento de vínculos familiares e comunitários, através da facilitação de um orientador social e da supervisão de um profissional técnico de referência do Centro de Referência em Assistência Social (CRAS).

Em 2013, houve um reordenamento dos SCFV no âmbito do Sistema Único de Assistência Social (SUAS), buscando aperfeiçoar a oferta de serviços para as diversas faixas etárias, bem como a consolidação e organização do serviço socioassistencial. Com o novo reordenamento, o cofinanciamento para o trabalho com crianças, adolescentes e idosos, antes repassado através de três pisos, foi unificado e o antigo Projovem Adolescente passou a configurar o SCFV para adolescentes de 13 a 17 anos. Esta pesquisa abrange os adolescentes que participaram de coletivos de Projovem Adolescente no bairro.

Os grupos de Projovem do bairro iniciaram, em meados de 2012, um movimento de tentativa de reativação do CLDSS. A ideia surgiu com a proposta de unir o protagonismo juvenil, traço marcante do grupo Projovem, com o movimento de participação local vinculado à saúde. Além disso, ao final do ano letivo no Projovem é necessário que os jovens elaborem e executem algum projeto de intervenção na comunidade. A orientadora social sugeriu e negociou com o grupo a possibilidade de transformar o projeto deles na reativação do CLDSS e todos foram favoráveis.
Os Conselhos Locais de Saúde surgiram no município de Sobral-CE no final da década de 90 através de mobilização das equipes do Programa de Saúde da Família, contando com apoio da gestão municipal. Foram denominados Conselhos Locais de Desenvolvimento Social e Saúde (CLDSS) por configurarem-se como movimentos contrahegemônicos, onde há efetiva participação comunitária que não necessariamente esteja vinculada ao CSF. (PONTE et al., 2012)

Conforme relato dos próprios jovens, o contato deles com o Centro de Saúde da Família (CSF) do bairro só ocorre quando estão doentes precisando de atenção médica, ou para acompanhar familiares em sofrimento ou nas campanhas programáticas, como as de vacinação, por exemplo.

A equipe de Residência Multiprofissional em Saúde da Família (RMSF), apoiada pelo Núcleo de Apoio à Saúde da Família (NASF), pelo Centro de Referência em Assistência Social (CRAS) e pelo CSF, propôs e realizou uma oficina sobre sexualidade como programação extra, mas dentro das atividades do Projovem. Naquele momento, iniciou-se a criação de vínculo entre jovens, profissionais de saúde e a ideia de reativação do Conselho de Saúde, como projeto de conclusão de curso deles, configurou o que Soratto, Witt e Faria (2010) denominam conhecimento situacional do grupo.

Ainda como parte da etapa de conhecimento situacional, foi realizado um breve resgate da história do Conselho, a partir de relatos de pessoas que participaram do Conselho anteriormente (profissionais de saúde e moradores) e do resgate de documentos de territorialização da RMSF. Nesse resgate, evidenciou-se que o Conselho estava inativo há algum tempo, mas que mesmo na época de atividade, a participação era praticamente só 
dos profissionais de saúde. Tanto que nem os jovens do grupo nem a facilitadora sabiam da existência do Conselho de saúde, mesmo realizando os encontros na mesma associação onde ocorriam as reuniões do antigo Conselho.

Para esclarecer melhor a proposta, tanto para os profissionais de saúde como para os jovens do grupo, ocorreu um encontro com o Gerente do CSF e com o articulador social do Conselho Municipal de Saúde, em que foi apresentado um breve histórico do movimento no bairro e feita uma explanação sobre a participação social. Nesse momento, surgiu a ideia de realizar um evento dentro da comunidade para dar mais visibilidade à atuação dos jovens e para propor uma conversa sobre conselho de saúde. Surgiu então, a ideia de organizar o "III Saúde no Parque do Mucambinho: Projovem em prol da Comunidade", com o intuito de realizar uma roda de conversa sobre Conselho e participação, prestigiar apresentações culturais locais e ofertar alguns serviços de saúde à comunidade.

Após a realização do evento, o grupo ganhou visibilidade na comunidade e após alguns encontros de formação e articulação política, finalmente, o Conselho do bairro foi reativado, tendo lideranças jovens na presidência e vice-presidência. Entretanto, o protagonismo juvenil do grupo que compõe o Projovem Adolescente do bairro não se limita à participação no Conselho local. A partir daí, formularam-se os seguintes questionamentos - base deste estudo: a participação dos jovens moradores do bairro promove saúde no território? Esses jovens percebem-se como sujeitos ativos e transformadores da realidade em que vivem? A comunidade e os trabalhadores da saúde consideram a participação dos jovens uma forma de promoção de saúde na comunidade?

Oestudo pretendedialogar comessas perguntas, tendo como objetivo geral investigar o impacto da participação social dos jovens moradores de um bairro de Sobral/CE, na promoção da saúde no território. Os objetivos específicos foram: a) investigar a percepção dos jovens a respeito da sua experiência pessoal de participação social dentro do território; b) investigar de que forma a participação social juvenil é promotora de saúde no território; c) apontar eventuais ganhos pessoais destacados pelos jovens com a experiência; d) descrever potencialidades e limitações na experiência de participação social juvenil no território.

\section{Percurso Metodológico}

A pesquisa foi realizada no período de outubro de 2013 a janeiro de 2014, totalizando um período de quatro meses. Conforme os objetivos, a pesquisa classifica-se como exploratória, pois busca constatar intuições e apurar ideias prévias. (GIL, 2002) Trata-se de uma pesquisa qualitativa com enfoque principal na observação-participante $e$ interação em campo, classificando o estudo como pesquisa participante e estudo de campo. Segundo Gil (2002), nesse tipo de pesquisa, faz-se necessária a imersão do pesquisador no campo de estudo, vivenciando o cotidiano dos sujeitos pesquisados, bem como observando e discutindo o tema com os mesmos, para posterior análise.

O local de realização do estudo foi um bairro do município de Sobral atendido por um Centro de Saúde da Família, cuja responsabilidade sanitária é de aproximadamente 7.463 pessoas no território. (SIAB/2012)

Os sujeitos da pesquisa são jovens moradores do bairro, entre 15 e 29 anos, conforme classificação de faixa etária jovem estabelecida pelo Conselho Nacional de Juventude - Conjuve. (BRASIL. SECRETARIA NACIONAL 
DE JUVENTUDE, 2013b) A escolha dessa faixa etária levou em conta a participação e interação dos sujeitos em diferentes locais de interação social dentro e fora do território, sugerindo uma abrangência mais expressiva das ações difundidas, em relação as outras faixas etárias. Para fins dessa pesquisa, utilizou-se apenas amostra de jovens participantes de espaços comunitários do bairro com potencial de promoção de saúde no território, como o Grupo Projovem Adolescente e o Conselho Local de Saúde e Desenvolvimento Social.

Os aspectos éticos e legais desta pesquisa têm como base os princípios da Resolução no 466 de 12 de dezembro de 2012 do Conselho Nacional de Saúde, que destaca as diretrizes e normas regulamentadoras de pesquisas envolvendo seres humanos. Todos os sujeitos participantes da investigação concederam aceite de participação na pesquisa mediante esclarecimento prévio do processo e assinatura de Termo de Consentimento Livre e Esclarecido (TCLE), Termo de Assentimento e Termo de Consentimento para os pais ou responsáveis (para menores de 18 anos).

Para a coleta de dados do estudo foram utilizados alguns instrumentos de pesquisa, a fim de facilitar a compreensão das impressões e sentidos dos sujeitos participantes. Dentro do contexto dessa pesquisa, destacamse: Observação-Participante, Pesquisa Documental e Grupo Focal.

$\mathrm{Na}$ pesquisa qualitativa, a observação-participante configura uma interação direta entre pesquisador e pesquisados, na qual o pesquisador insere-se na realidade em que vivem os sujeitos da pesquisa, vivenciando essa realidade de uma forma empírica. Conforme aponta Minayo (2007), quando o pesquisador participa da vida dos sujeitos da pesquisa, tornando-se parte do contexto do estudo, ele acaba modificando e sendo modificado por esse contexto.
Foram utilizados também documentos relevantes para a pesquisa que não possuem tratamento analítico prévio, como atas e relatórios do CLDSS. Para tanto, a presidente do referido Conselho autorizou a utilização dos documentos mediante assinatura de Termo de Fiel Depositário.

O grupo focal é uma técnica que busca obter informações da pesquisa em grupos menores, gerando discussão norteada por roteiro previamente estabelecido e levando em consideração as falas e a interação em grupo; podendo apresentar consenso ou divergência em relação ao tema da pesquisa. (MINAYO, 2007) Nessa pesquisa foram realizados dois grupos focais. Para o primeiro grupo, composto apenas pelos jovens sujeitos da pesquisa, foi utilizado um roteiro baseado nos objetivos específicos: "a" e "c". Já para o segundo grupo, foram convidados outros atores da comunidade e trabalhadores da saúde com discussão mais voltada para os objetivos específicos " $b$ " e "d".

Para a análise e compreensão do material coletado, foi utilizada uma das formas mais frequentes em pesquisas qualitativas: a análise de conteúdo. Essa técnica de pesquisa configura-se como uma análise das comunicações através de procedimentos sistemáticos, visando a compreender as informações para dedução de conhecimentos referentes às condições de produção. (BARDIN, 1979) Dentro das modalidades de análise de conteúdo nas pesquisas qualitativas, destaca-se a análise temática, que foi a metodologia de análise usada nessa pesquisa.

Uma análise temática trabalha com a noção de temas principais apreendidos através da coleta de dados, buscando formular sentidos a partir dessa categorização. Segundo Minayo, "a análise temática consiste em descobrir os núcleos de sentido que compõem uma comunicação cuja presença ou frequência signifique alguma coisa para 
o objetivo analítico visado." (MINAYO, 2007, p.316) Ainda conforme a autora, a análise temática divide-se em três fases, que foram seguidas nesse estudo: 1) pré-análise, em que se realiza uma leitura geral para exploração inicial do material; 2) exploração do material, onde primeiro realiza-se um recorte do texto, depois definem-se regras de classificação e por último, é feita a divisão em categorias; 3) tratamento dos resultados, destacando as informações obtidas para apreciação.

\section{Resultados e discussão}

Durante a inserção nos grupos, realização de visitas domiciliares e outras vivências comunitárias, no exercício de observação-participante, evidenciou-se que as principais experiências de participação social juvenil existentes no bairro estiveram atreladas a projetos sociais, como o Projovem, os grupos de esporte, dança e de outras manifestações culturais. Geralmente, a noção de participação social está vinculada diretamente à política eleitoral ou às instâncias de controle social institucionalizadas. Entretanto, o que se percebe é que nas comunidades, no local de moradia das pessoas, são desenvolvidas atividades que mobilizam e envolvem os sujeitos daquele lugar, buscando combater as dificuldades e fortalecer o poder popular, promovendo assim, o desenvolvimento comunitário. Gois (2008) ressalta que o desenvolvimento comunitário não se reduz somente ao preconizado pelas políticas públicas, pois trata-se de uma cooperação entre agentes internos e externos à comunidade, uma vez que considera a vontade dos moradores, sua cultura e suas possibilidades.

Nas falas dos diversos atores da comunidade (jovens, trabalhadores de saúde, pais, lideranças comunitárias), tanto durante os grupos focais, quanto em outros momentos, evidenciou-se a falta de apoio por parte das políticas públicas, o que fragiliza as atividades desenvolvidas na comunidade. A participação popular deve partir da comunidade, mas também necessita de apoio governamental, numa lógica de cooperação. A falta de estrutura física, de equipamentos e projetos sociais dentro do bairro acaba limitando a participação comunitária e, consequentemente, a juvenil:

Lá no meu bairro lá é muito carente, porque você vê que tem educadores só no poliesportivo. $O$ educador era pra ser dentro da comunidade das periferias. Porque lá dentro ele só vê aquele quadrado lá do poliesportivo. [...] tem o educador do primeiro tempo, segundo tempo... acho que acabou até o segundo tempo, né? Esse povo aí era pra trabalhar dentro da comunidade, praticando esporte com os meninos na localidade, tá tendo psicólogo nas comunidades do bairro também, pra poder colocar as reuniões com os meninos. Ter um psicólogo e um analista, pra indicar alguns conhecimentos pra aqueles jovens pra que eles saibam o que é uma ação social. (Morador A)

Os serviços eles realmente precisam ser descentralizados, eles irem realmente pra onde está a comunidade. Porque não adianta eu ter uma escola de música, ter uma casa do papai noel lá no centro, eu ter um monte coisa concentrada num espaço, que nem transporte eu tenho pra chegar até lá. Então a gente precisa tá lutando pra essas políticas tá dentro da comunidade. (Trabalhador A) 
Novaes e Vital (2005) apontam que há uma visão negativa ligada à participação juvenil por conta da baixa adesão na participação política. No entanto, essa característica estende-se as diversas faixas etárias, mostrando que a "condição juvenil" apenas reflete o que ocorre na sociedade em geral. As autoras afirmam ainda, que essa característica em muitos segmentos juvenis gera uma reapropriação da noção de cidadania, implicada com a inclusão social, a valorização dos espaços coletivos e dos direitos, apresentando ações concretas em diferentes espaços de participação, que não necessariamente os classificados como políticos.

Para investigar o impacto da participação social dos jovens moradores do bairro, na promoção da saúde no território, foram definidos objetivos específicos que facilitaram a coleta de dados, através de grupos focais norteados por perguntas baseadas nesses objetivos. Após leituras e análise do material coletado, foram categorizados os principais núcleos temáticos evidenciados pelas falas. As regras de classificação utilizadas para a categorização, durante a fase de exploração do material, foram: a frequência de alguns núcleos de sentidos nas falas e sua relevância para os objetivos.

Em relação à percepção dos jovens acerca da sua experiência pessoal de participação no território, bem como ganhos pessoais percebidos pelos mesmos, foram identificados os seguintes núcleos temáticos: aprendizado, melhoria das relações familiares, oportunidades, conhecer pessoas, entretenimento e bem-estar. A partir desses núcleos já se começa a perceber alguns impactos da participação na promoção da saúde no território, bem como alguns desafios e potencialidades da experiência.

Conforme o discurso dos jovens, as experiências de participação agregam bastante conhecimento, pois quando eles reúnem-se em grupos ocorrem trocas de experiências e aprendizado, o que promove uma melhor compreensão acerca do mundo e da realidade em que estão inseridos. Relatam:

Depois que eu entrei no Projovem é que eu fui conhecer as políticas públicas voltadas pro jovem, as políticas públicas voltadas pros idosos também e pras crianças. E aí foi mesmo assim, uma elevação de grau, foi mesmo bem massa mesmo pra mim e acredito que pros meninos também, porque a gente passou a conhecer coisas que a gente não conhecia, direitos enquanto... muitos eram adolescentes, né? Num sabiam seus direitos e deveres, e com o Projovem a gente passou a conhecer os nossos direitos e deveres. (Jovem A)

Para fundamentar a categoria melhoria das relações familiares, é importante atentar para a existência de novos arranjos familiares na atualidade, pois as relações estabelecidas na contemporaneidade refletem-se diretamente no que podemos conceituar como família. Estudos apontam que a família brasileira, apesar de vir sofrendo enfraquecimento e desagregação, ainda é um importante espaço de socialização e de exercício de cidadania. Serapioni (2005) conceitua família como um intercâmbio simbólico de gêneros e gerações, mediados pela cultura e natureza, tanto na esfera pública como na privada. Segundo os relatos nos grupos focais, conhecer pessoas diversas e diferentes facilita a maneira de se relacionar com as famílias e constrói vínculos de amizades que são importantes na cooperação em prol da comunidade e na promoção da saúde: 
O conceito de saúde é muito abrangente, aí tipo você conhecendo algumas coisas melhora o seu ambiente familiar, melhora sua relação com os amigos... $E$ isso o Projovem fez muito bem! Porque tipo lá a gente interagia com outras pessoas que a gente não conhecia... Muito legal! (Jovem B)

Assim e eu era de uma família que não era bem estruturada, né? Os meus pais se separaram e aí era um momento de distração pra mim. Eu tive um ponto de vista melhor da vida. Porque eu tava na associação e minha vó não podia ir, as pessoas sempre convidavam ela... E eu trabalhava diretamente com idosos e eu queria muito bem que a minha avó estivesse lá pra poder tá trabalhando também com ela, mas não dava. Mas foi assim uma transformação muito boa mesmo trabalhar com essas faixas etárias, com crianças, idosos e aí tinha a minha participação no Projovem adolescente. (Jovem A)

Ave Maria, me sentia muito bem quando meus filhos tavam no Projovem! Aquela participação, a festa de mães, aquele grupo de pais que a gente participava duas vezes no mês, meus filhos... Aquele sorriso chegava, meus filhos diziam assim: mãe, eu te amo! Uma mãe dá de tudo prum filho, mas ter uma participação de uma moça pra educar mais sabe, ele se sente muito melhor! Então eu queria que nosso bairro, na nossa comunidade tivesse mais assistente social, mais psicólogo, nós precisamos muito! Então o jovem caminha cada vez mais! Aí se nós num tem nesse bairro o jovem vai ver o que no mundo dele? Ele vai ver o que vier pela frente, na visão dele, ele num vai saber o que é certo e errado não. (Morador C)
Os grupos frequentados pelos jovens também são destacados como importantes espaços de entretenimento e distração, uma vez que retiram os jovens da ociosidade e os afastam da possibilidade de envolvimento com drogas e violência, elementos muito presentes no bairro. Onde, inclusive, há expressiva participação juvenil em grupos de movimentos populares de rua, como o hip hop e o basquete de rua, como forma de prevenir o envolvimento com a dependência e o crime, além de fortalecer a cultura de rua, com apoio de movimentos sociais. Nos grupos focais, destacaram-se ganhos tanto para o jovem, quanto para a comunidade, pois eles associam esses espaços à saúde e bem-estar, uma vez que ali sentem-se bem e úteis para a comunidade:

Eu acho que foi assim, foi importante pra comunidade porque puderam ver que dentro da nossa comunidade tinha algo pra entreter os adolescentes, porque no mundo de hoje, né? Tem muito adolescente envolvido com drogas, esse tipo de coisa. E com algo desse na comunidade era mais uma oportunidade pra tirar esse jovem dessas drogas e levar pro meio assim, mais do estudo, do caminho certo, né? Então eu acho que isso, foi sim importante pra comunidade. $E$ acho que isso eles veem que foi importante por conta disso, porque a gente poderia sim tá fazendo outro tipo de coisa errada na rua. Mas não, a gente tava ganhando conhecimentos, vendo valores... Acho que isso foi importante pra comunidade!

[...]

Que eu gosto muito de dançar, né? Danço swingueira, danço quadrilha... $E$ eu me sinto muito bem dançando, então eu vejo que antes quando eu não dançava era 
assim diferente. Já hoje, eu já me sinto bem, já me sinto uma pessoa até mais leve e mais, digamos, bem mais feliz. Porque dançar faz bem, né? E isso eu vejo a diferença de antes pra agora. (Jovem C)

Em relação às oportunidades geradas a partir das experiências de participação juvenil, os jovens destacaram em suas falas tanto o desenvolvimento pessoal como o comunitário. Alguns jovens recusaram a participação nos momentos de grupo focal pela falta de disponibilidade de horário, em decorrência de emprego ou de atividades extras, ambos proporcionados através de oportunidades geradas pelos coletivos do Projovem, conforme relatos durante o convite para essa dinâmica. Também nas falas dos trabalhadores e moradores, destacaram-se os jovens engajados em atividades comunitárias e a consequente conquista de oportunidades de crescimento.

Eu participava como voluntário na associação e lá eu desenvolvia atividades com crianças, com adolescentes, com idosos, né? Mas pra poder a juventude ter esse espaço as pessoas teriam que dar as oportunidades, que tipo foi-me dado. Foime dado oportunidade e aí gostaram do meu trabalho, viram que eu era dedicado, e aí me deram umas... faz isso, pode fazer aquilo, me deram total liberdade pra poder tá desenvolvendo essas atividades, tá interagindo com a comunidade em si... (Jovem A)

Eu acho que o jovem, se eles tiverem engajado num projeto desses né? Seja Projovem, ou seja no esporte, eles vão tá aprendendo, vão tá vendo exemplos de outras pessoas que foram bem sucedidas.

[...] Eles são jovens participativos que tão no meio de alguma ação da comunidade e aquele jovem vai ser visto de outro modo, de outro olhar, por conta que ele está inserido nos movimentos sociais e que dali ele aprendeu algo que vai passar pra outras pessoas e no ambiente do trabalho vai ser uma coisa saudável que ele já tem o convívio né? Com diferentes opiniões, com diferentes pessoas. Acredito que é muito importante ele estar inserido num projeto social. O que teve de mudança é que ele se sobressai. Como teve vários exemplos de meninos que saíram do Projovem foram pra guarda-mirim, muitos deles completaram o ciclo com 18 anos, foram pra entrevista de emprego e hoje tão empregados com carteira assinada. Acho que só tem a contribuir! (Morador B)

As falas dos profissionais e moradores do bairro corroboram com as categorias evidenciadas nas falas dos jovens, porém, demonstram mais a percepção desses atores acerca das formas como a participação juvenil promove saúde no território. É importante ressaltar aqui que promover saúde é entendê-la como parte da cultura, dos modos de viver e das condições políticas e sociais da comunidade. Não é apenas responsabilidade das instâncias de gestão em saúde, mas também das pessoas que vivem na comunidade, num movimento de cooperação direcionado para o desenvolvimento comunitário. A partir da compreensão dos determinantes sociais em saúde, o sujeito torna-se consciente da sua condição dentro de determinado contexto social, promovendo saúde para si e para seu entorno, conforme declaração de um dos trabalhadores de saúde:

Quando eu tenho o conhecimento de algo, quando eu tenho coisas determinadas na minha vida do que é saúde, do que é educação, do que é esporte, do que é lazer, 
então, a importância disso na minha vida, eu já 'tou promovendo saúde. E aí isso vai se espalhando pra dentro da minha casa, como eu já falei, de tudo começar dentro da família, dentro da comunidade. Porque ali eu vou ser um jovem que eu posso estar buscando espaços que eu possa realmente me emancipar, exercer meu protagonismo juvenil, buscar de repente uma visão de futuro melhor. Eu vou ser menos um jovem que vou tá inserido num espaço que tem pessoas usando drogas, vou estar sendo um bom exemplo até.

[...]

E assim pra promover saúde mesmo precisa que essas políticas que existem sejam mais no sentido de emancipatórias. Porque a gente tem muitas políticas que: aí eu dou bolsa família, mas eu não tenho uma equipe suficiente pra acompanhar as condicionalidades, pra desenvolver as potencialidades da família inteira. Porque o jovem ou uma mãe não é só uma pessoa como eu falei, ela está dentro de uma família, dentro de um bairro, dentro de uma comunidade. Essas interrelações precisam ser mais fortalecidas. Aí nossa saúde vai melhorar. (Trabalhador $A$ )

A análise das informações trouxe à tona alguns desafios evidenciados nas falas, principalmente no que tange à dificuldade de participação comunitária, à falta de apoio governamental e políticas públicas na comunidade. Para que os sujeitos sejam mais autônomos é preciso também que haja apoio governamental, promovendo a cooperação entre entes internos e externos à comunidade, e construindo melhorias de forma conjunta e com os recursos básicos necessários. Entretanto, deve-se atentar para a forma como essas políticas são implementadas no território, para que não sejam meros mecanismos burocráticos e de dominação, mas sim, uma construção conjunta na direção da potencialização da comunidade a partir da realidade local. (GÓIS, 2008)

Dentre os desafios apontados nas falas, também se ressalta a importância do cuidado e do fortalecimento das famílias para que haja promoção da saúde, de fato, no território, afinal, é na unidade familiar onde se constituem os sujeitos comunitários. Aliado a isso, a família moderna e as comunidades vêm apresentando maior envolvimento em suas próprias demandas sociais. (SERAPIONI, 2005) Nas falas apreendidas nos grupos focais, um dos trabalhadores de saúde destacou tanto a importância do trabalho de base familiar como da conscientização dos jovens, sujeitos constituintes das famílias e comunidade, e também responsáveis pelas demandas sociais e transformação da vida comunitária:

Porque assim, eu olho a base familiar em tudo, ele tá reproduzindo esses comportamentos. A família não tá sendo trabalhada, orientada no sentido de ser responsável pelos seus filhos. As famílias não querem mais ter trabalho, não querem mais... Assim eles nem têm estrutura, porque geralmente eles vêm de pais que vêm repetindo a mesma coisa, filhos e pais de mães solteiras. Precisa haver esse trabalho pra tentar mudar as novas gerações.

[...]

Eu acredito que vai começar a haver mudanças a partir do momento que a geração nova começar a se apropriar. Eles fazem parte da comunidade, né? Eles podem ajudar a construir uma comunidade melhor, né? Eles desde cedo precisam 
ter essa conscientização, né? Que eles têm que participar, que eles têm que ter voz, ter vez, reivindicar seus direitos, né? Reivindicar o que eles acham, não assim colocar nas mãos de outras pessoas, mas eles já têm consciência de que eles podem se apresentar e reivindicar, né? Melhorias pra comunidade, pra própria vida dele. (Trabalhador B)

Com isso, percebe-se a importância de investir esforços no fortalecimento da participação juvenil no território, desenvolvendo uma tecnologia leve ${ }^{1}$ em saúde como importante estratégia de promoção da saúde e desenvolvimento comunitário. Thompson (2005) destaca que, atualmente, há uma necessidade de reconhecimento do jovem como protagonista do desenvolvimento local e por isso, a importância de "associar-se à juventude" como estratégia de transformação da realidade, pois esses atores são capazes de intervir nas comunidades, famílias, escolas, nos seus pares e na sociedade em geral. Portanto, ao se pensar em políticas públicas para juventude é importante levar em conta a característica participativa.

\footnotetext{
${ }^{1}$ Segundo Merhy (2003) as tecnologias leves em saúde enfocam elementos relacionais entre trabalhadores e usuários na produção do cuidado em detrimento das tecnologias duras, que tratam dos instrumentais de trabalho e das leve-duras, que dizem respeito aos campos científicos de saberes.
}

\section{Considerações Finais}

Percebendo a promoção da saúde como uma importante estratégia para o desenvolvimento pessoal e comunitário, ressalta-se a relevância do envolvimento e mobilização social no território. Os moradores como principais atores da comunidade, na busca de condições mais justas de saúde e de vida, ao se apropriarem das suas próprias demandas sociais, de forma consciente e implicada, conseguem mobilizar-se e realizar atividades que fortalecem o desenvolvimento local. A importância do segmento juvenil nessa empreitada fundamenta-se, principalmente, no fato de grande parte da população ativa no mundo integrar a faixa da juventude e essa faixa transitar por diversos lócus da sociedade.

A pesquisa mostrou que ainda existem inúmeras dificuldades na mobilização e participação comunitária, por conta, sobretudo, da falta de incentivos através de políticas públicas. Entretanto, a apatia por parte dos moradores acaba restringindo bastante as atividades comunitárias e o consequente desenvolvimento local. É necessário um trabalho de cooperação entre sujeitos e políticas, de forma integrativa, visando a conscientização para transformação das condições de vida locais.

Atualmente, no bairro, são desenvolvidas poucas atividades comunitárias, sendo parte delas atreladas a projetos sociais desenvolvidos por políticas governamentais e assistencialistas, interessadas somente na manutenção do status quo, em que pouco se trabalha o empoderamento e autonomia dos sujeitos. Por isso, neste estudo, a maioria dos relatos voltou-se para experiências exitosas passadas em projetos sociais, somada à ênfase na falta de participação da comunidade do bairro. Com a extinção de alguns projetos, também decaiu o interesse na participação 
em atividades comunitárias de forma independente. Ainda assim, mesmo com algum caráter assistencialista, os poucos espaços de participação identificados no território revelam grande importância no fortalecimento de vínculos e na promoção da saúde, porém, necessitam de práticas mais voltadas para a conscientização e valorização das pessoas e da comunidade. Reconhecer o jovem como protagonista do desenvolvimento comunitário pode ser uma importante estratégia de transformação da realidade para a emergência de formas mais saudáveis, belas e justas de vida.

\section{Referências}

BARDIN, L. Análise de conteúdo. Lisboa: Ed. 70, 1979.

BRASIL. Presidência da Repúbica. Lei 8142/90, 28 de dezembro de 1990. Dispõe sobre a participação da comunidade na gestão do Sistema Único de Saúde (SUS) e sobre as transferências intergovernamentais de recursos financeiros na área da saúde e dá outras providências. Brasília, 28 de dezembro de 1990.

BRASIL. Ministério da Saúde. Secretaria de Vigilância em Saúde. Secretaria de Atenção à Saúde. Política Nacional de Promoção da Saúde. Ministério da Saúde, Secretaria de Vigilância em Saúde, Secretaria de Atenção à Saúde. 3ed. Brasília: Ministério da Saúde, 2010.

BRASIL. Ministério do Desenvolvimento Social e Combate à Fome. Assistência Social. Proteção Básica. Serviços. Projovem Adolescente. Site do Ministério do Desenvolvimento Social e Combate à Fome, 2013a. Disponível em: <http://www. mds.gov.br/assistenciasocial/protecaobasica/servicos/ projovem>. Acesso em: 19 mai 2013.
BRASIL. Secretaria Nacional de Juventude. Cartilha de Políticas Públicas de Juventude. Brasília, 2013b. Disponível em: <http://www.juventude.gov.br/guia>. Acesso em: 05 abr 2013.

ESCOREL, S.; MOREIRA, M.R. Participação Social. In: GIOVANELLA, L.; ESCOREL, S.; LOBATO, L.V.C.; NORONHA, J.C.; CARVALHO, A.I. (Org.). Políticas e sistema de saúde no Brasil. Rio de Janeiro: Fiocruz/Cebes, 2008. p.979-1010.

GIL, A.C. Como elaborar projetos de pesquisa. 4ed. São Paulo: Atlas, 2002.

GÓIS, C.W.L. Saúde Comunitária: pensar e fazer. São Paulo: Hucitec, 2008.

MERHY, E.E.; FRANCO, T.B. Por uma Composição Técnica do Trabalho Centrada nas Tecnologias Leves e no Campo Relacional. In: Saúde em Debate, Ano XXVII, v.27, n. 65, Rio de Janeiro, Set/Dez de 2003.

MINAYO, M.C.S. O desafio do conhecimento: pesquisa qualitativa em saúde. 10ed. São Paulo: Hucitec, 2007.

NOVAES, R.; VITAL, C. A juventude de hoje: (re)invenções da participação social. In: Associando-se à juventude para construir o futuro. Organizador Andrés A. Thompson et al. Revisão e tradução do espanhol Fernando Legoni. São Paulo: Petrópolis, 2005. Disponível em: <http://www.espm. br/>. Acesso em: 18 abr 2013.

PONTE et al. Território e a Estratégia Saúde da Família: uma reflexão e um desafio. In. Território, Cultura e Identidade. Fernando Antonio Cavalcante Dias e Maria Socorro de Araújo Dias (Orgs). Rio de Janeiro-RJ: Editora Abrasco, 2010.

PONTE, H.M.S. et al. O caminho se faz ao caminhar: processo de reativação de conselhos locais de saúde em Sobral, a 
partir do protagonismo cidadão. In: Saúde soc. [online], 2012, v.21, supl.1, p.234-243.

SERAPIONI, M. O papel da família e das redes primárias na reestruturação das políticas sociais. In: Ciência \& Saúde Coletiva, 10(sup.), p.243-53, 2005.

SORATTO, J.; WITT, R.R; FARIA, E.M. Participação popular e Controle Social em Saúde: Desafios da Estratégia Saúde da Família. In: Physis, Rio de Janeiro, v.20, n.4, 2010.

THOMPSON, A.A. Associando-se à juventude para construir o futuro. In: Associando-se à juventude para construir o futuro. Organizador Andrés A. Thompson, et al. Revisão e tradução do espanhol Fernando Legoni. São Paulo: Peirópolis, 2005. Disponível em: <http://www.espm.br/>. Acesso em: 18 abr 2013.

VASCONCELOS, C.M.; PASCHE, D.F. O Sistema Único de Saúde. In: CAMPOS, G.W.S. et al. (Org.). Tratado de Saúde Coletiva. São Paulo/Rio de Janeiro: Hucitec/Fiocruz, p.531562, 2009.

\section{O ESPORTE EDUCACIONAL COMO ESTRATÉGIA NA CULTURA DE PAZ}

Igor Carneiro Gomes Leo Barbosa Nepomuceno Braulio Nogueira de Oliveira

\section{Introdução}

Este estudo pretende contribuir com a Estratégia Saúde da Família (ESF) trazendo reflexões sobre a experiência vivida na Residência Multiprofissional em Saúde da Família (RMSF), na construção de ações voltadas para o combate à violência, através de práticas esportivas com jovens do bairro Padre Palhano em Sobral, Ceará. Assim, buscamos sistematizar uma reflexão sobre ações de promoção da saúde, associando atividade física e cultura de paz, bem como apontar caminhos que utilizam o esporte como intervenção sociocomunitária, ampliando a importância do professor de Educação Física e Esportes nos processos de educação em saúde nos territórios da ESF. 
Concebemos o esporte como uma estratégia relevante para a promoção da saúde comunitária. Tomamos como referências teóricas as ideias de Tubino (1993) e Helal (1990), destacando a multiplicidade de sentidos sociopsicológicos das práticas esportivas, que nos possibilitam uma variedade de metodologias no uso da intervenção através do esporte. Destacam-se, nesse contexto, as seguintes dimensões sociais do esporte: o esporte rendimento, voltado para o aumento da performance esportiva com diversos públicos de participantes; o esporte educacional, especialmente ligado ao esporte na escola; o esporte-participação, voltado para a promoção de sociabilidades; e o lazer, estimulando as redes sociais comunitárias. (TUBINO, 1993; STIGGER, 2005) Dentre estes, o esporte educacional e o esporte-participação nos serviram de referência para o desenvolvimento desse projeto, por ter suas definições similares aos processos de educação em saúde utilizados na ESF.

De acordo com Tubino (1993), o esporte-educação ou esporte educacional tem na sua essência: participação, cooperação, coeducação, integração e responsabilidade. São essas as características que tornam essa metodologia a que detém maior potencialidade socioeducacional, sendo uma tecnologia adequada para as estratégias de educação em saúde. Helal (1990) nos faz refletir sobre a relevância do esporte como elemento da cultura corporal na sociedade. Assim, levantamos algumas indagações que nos foram pertinentes à elaboração do trabalho: Qual esporte é mais praticado na sua cidade? Quem pratica esse esporte? Qual o horário mais utilizado para praticar esse esporte? Quais os recursos utilizados para jogar? Como o esporte pode ajudar com a não violência? Essas perguntas foram utilizadas para captar informações da cultura local e global, e reafirmar o esporte como uma cultura do povo, a qual nos guia para uma prática de atividade física que tenha significado na promoção da saúde e cultura de paz.
O Sistema de Notificações e Agravos (SINAN) contém dados sobre a violência em Sobral, que comprovam a frequência de ações violentas, principalmente partindo de adolescentes do gênero masculino. Devido a essa realidade, surgiram muitas ações, dentre as quais: a fundação da Organização Não Governamental Construtores da Paz; a instalação de uma Secretaria Municipal Especial de Juventude; e a realização de eventos organizados pelas escolas públicas do bairro Padre Palhano, em parceria com o Centro de Saúde da Família (CSF). Com o objetivo de contribuir com a promoção da paz no território em questão, seguimos a Política Nacional de Promoção da Saúde (BRASIL. MINISTÉRIO DA SAÚDE. SECRETARIA DE VIGILÂNCIA EM SAÚDE, 2006), especialmente, no que diz respeito ao estímulo a modos de vida não violentos e ao desenvolvimento de uma cultura mais pacífica no país. Ainda pautados no mesmo documento, buscamos a promoção de práticas corporais e de atividade física, ambas voltadas para a oferta de práticas lúdicas de lazer e esporte na rede de atenção primária à saúde, o que possibilitaria atender a comunidade e a grupos vulneráveis.

Partindo do processo de territorialização vivenciado na RMSF, foi elaborado um plano de ação e constituído um grupo de práticas de esporte educacional com crianças e adolescentes, tendo como cuidador o professor de Educação Física na condição de profissional de saúde de referência na ESF. O grupo foi chamado de Gaviões da Paz. Os encontros começaram em maio de 2012 e foram pactuados às terças e quintas, das $8 \mathrm{~h}$ às $11 \mathrm{~h}$ da manhã, quando foram praticados os esportes: futsal e futebol, respectivamente, na quadra e no campo comunitário do bairro. Após um ano do início do Gaviões da Paz, surgiram algumas inquietações: o grupo promove a paz? O esporte educacional é uma metodologia que pode ser utilizada na Estratégia Saúde da Família? Dentre tantos pensamentos, 
este estudo pretendeu responder ao questionamento: o esporte educacional contribui para a promoção da paz no grupo de crianças e adolescentes do bairro Padre Palhano, Sobral - CE?

Um diferencial dessa intervenção, conforme a concebemos, é que não estamos falando somente do esporte enquanto jogo na escola, mas sim, de uma metodologia de ação em esporte educacional, que se aproxima dos cuidados em saúde na comunidade, uma tecnologia voltada para a promoção da saúde e da cultura de paz.

Nosso estudo buscou discutir estratégias que tentam superar o desafio, levantado por Merhy (2007), de transformar atos de saúde em atos cuidadores, na atenção primária à saúde, no que diz respeito às práticas corporais e esportivas. O autor, ao discutir sobre práticas em saúde, lembra-nos que, a partir da perspectiva dos usuários, os grandes descontentamentos geralmente não estão ligados à falta de conhecimentos tecnológicos, mas relacionados ao desinteresse e desresponsabilização dos serviços de saúde para com o usuário e sua situação nesse caso. Dessa forma, concluímos que há uma tecnologia leve a qual devemos nos ater, que causa implicações diretas na produção de processos relacionais como atos de saúde, os quais chamamos de atos cuidadores.

Para Merhy (2007), as tecnologias presentes no trabalho em saúde podem ser classificadas como leves, leveduras e duras. As tecnologias leves utilizam como recurso as relações, através das quais se estabelece o vínculo, o acolhimento, a forma de gestão. Já as leve-duras estão relacionadas a um saber estruturado como, por exemplo, a clínica médica, a clínica psicanalítica ou o taylorismo. As tecnologias duras são os equipamentos, que incluem tanto máquinas como normas organizacionais. (MERHY, 2007)
Aqui, entendemos que as práticas de esporte educacional desenvolvidas são exemplos de tecnologias leves, tomando como referência um conjunto de relações interpessoais que subsidiaram as intervenções do professor de Educação Física, sob os princípios da participação, cooperação e responsabilidade.

A cartilha do Humaniza SUS (BRASIL. MINISTÉRIO DA SAÚDE. SECRETARIA DE ATENÇÃO À SAÚDE. NÚCLEO TÉCNICO DA POLÍTICA NACIONAL DE HUMANIZAÇÃO, 2008a) relembra que as políticas públicas de saúde são pautadas nos princípios doutrinários da integralidade, universalidade e equidade, e incorporam novas tecnologias, saberes e práticas. Este estudo pretendeu seguir esses ideais na prática dos serviços de saúde no SUS e contribuir com a ampliação das tecnologias utilizadas na Estratégia Saúde da Família, especificamente com as contribuições da Educação Física, disciplina e profissão que tradicionalmente utiliza o esporte para promover a saúde e a cultura corporal.

Seguir as recomendações dos documentos que norteiam as ações do sistema de saúde é um bom começo, mas não podemos esquecer que existe uma realidade dinâmica. Para Gáspari et al. (2001), há em cada civilização um contexto histórico-cultural que compreende de modo diferente as fases da vida humana, definindo a duração, suas características e direitos legais. Portanto, defendemos a necessidade de refletir sobre as práticas, a fim de construir uma política de promoção da saúde significativa e reagir de forma positiva aos ideais propostos.

Na política de promoção da saúde, a atividade física tem sua valia e suas peculiaridades, sendo que o esporte tem destaque, contudo, para Pinto (2009), existe uma grande divulgação do esporte de rendimento, portanto é necessário adotar outra visão de esporte para a ESF. O que pretendemos ressaltar é o esporte como agregador e 
socializador, promotor da cultura corporal de paz, de modo que não cause segregações ou lesões por atitudes violentas, repetições de movimentos, cobranças psicológicas pela eficiência e etc. Como já dito, o esporte tem um papel importante na nossa cultura. Segundo Tubino (2010), é um dos fenômenos socioculturais mais importantes dessa transcrição de séculos, em função disso, tem recebido atenção especial da mídia internacional, ao passo que intelectuais aprofundam-se em suas dimensões políticas, sociais, culturais, educacionais, científicas e antropológicas. $\mathrm{O}$ autor quando se refere à questão educacional traz para este estudo a indicação da forma como esse movimento cultural pode contribuir com a saúde dentro das ações de promoção da saúde (cultura de paz) nas áreas que necessitam dessa atenção especial.

Segundo Sanches et al. (2001), são vários os estudos sobre a importância educativa do esporte e seus benefícios para o desenvolvimento físico, social e afetivo dos participantes. Trabalhar o esporte na dimensão pedagógica é desafiador, pois ficamos vulneráveis aos esportes midiáticos - o esporte-espetáculo, o esporte de rendimento - e podemos perder a essência educacional de transformação, nos encantando e reproduzindo apenas as disputas e rivalidades do desporto.

As crianças e adolescentes têm diferentes oportunidades no seu desenvolvimento, dadas por seus atributos físicos/mentais e pelo meio social em que vivem. (HALPERN et al., 2004) Colocando em prática essa afirmação, na nossa realidade, observamos uma complexidade de fatos que acontecem no território e que são motivados por diversos atores, sendo muito complexa a atuação do profissional e da equipe de trabalho.

Dentre os esportes mais populares no território do Padre Palhano, percebemos que o futebol era o grande mobilizador da juventude, especialmente dos jovens do sexo masculino. O futebol tem, aliás, dentre suas regras, a falta, sendo algumas delas violentas, agressivas. Nas atividades desenvolvidas pelo professor de Educação Física com futebol, no referido território, as faltas violentas eram constantes, expressando uma cultura corporal marcada pelo excesso de agressividade e pela vontade de vencer a qualquer custo. Observamos que essa prática precisava ser direcionada para a promoção da saúde e de práticas mais amistosas e leais. Nesse sentido, o trabalho com o Gaviões da Paz foi conduzido na linha do esporte educacional, guiando-nos para o incentivo de uma prática esportiva com mais significado para o coletivo dos jovens praticantes. Assim, foi preciso alterar as regras do jogo de futebol, ampliando as restrições às faltas violentas e possibilitando uma metamorfose metodológica na experiência vivida com o esporte.

A violência não é algo simples de entender. Para Minayo et al. (1998), esse tema é universal, porém, precisa ser especificado, dialogado em cada contexto. Devido a essa questão plural, trata-se de um tema complexo. Para a autora, existem duas correntes: uma que defende o homem como um ser biológico, portanto, é natural que tenha atitudes violentas; e outra que delega, aos fatores sociais, o comportamento humano. Os esforços empreendidos no enfrentamento da violência não têm sido poucos. Vastos são os trabalhos desejando promover a paz. Na obra Brasil (MINISTÉRIO DA SAÚDE. SECRETARIA DE ATENÇÃO À SAÚDE. NÚCLEO TÉCNICO DA POLÍTICA NACIONAL DE HUMANIZAÇÃO, 2008b), temos alguns exemplos: Política Nacional de Redução da Morbimortalidade por Acidentes e Violências, Política Nacional de Promoção da Saúde e a Rede Nacional de Atenção Integral às Mulheres, Adolescentes e Crianças em situação de violência doméstica e sexual. 
Para as políticas que pretendem promover a cultura de paz, Milani (2003) faz referência a dois níveis de atuação que devem ser trabalhados na promoção dessa cultura, onde o primeiro (micro) refere-se a abordagens individuais do indivíduo, seus comportamentos, sua relação familiar, a vida no trabalho e na comunidade. Já o segundo nível (macro), fala sobre novos processos sociais, criativos, estratégias coletivas, criação de políticas públicas, instituições e programas educativos que condizem com os valores da paz.

Na realidade de Sobral, segundo os dados de 2012 do SINAN, da vigilância epidemiologia daquele município, foram registrados: 163 casos de violência física, 24 casos de violência psicomoral e 10 casos de violência sexual. Estes dados são apenas recortes de um levantamento sobre as diversas violências ocorridas e que servem como base para realizar as ações de promoção da cultura de paz. De acordo com a mesma fonte, $9,2 \%$ da violência física gerada na cidade é oriunda do bairro Padre Palhano, e desse total, $66,6 \%$ das ações violentas ocorrem com o envolvimento de adolescentes e jovens. Os dados apontam que 73,3\% das ações de agressão física ocorrem em vias públicas do bairro e $26,7 \%$ nas residências. O bairro ocupa o segundo lugar em casos de violência sexual, crime responsável por $20 \%$ das notificações, e a mesma posição, em violência psicomoral, com $16,6 \%$ dos casos. É necessário compreender também que existe uma subnotificação por questões diversas, sendo alguns exemplos: a vítima que não notifica o caso à unidade de saúde, pedidos de sigilo por parte do usuário, repressão por parte do agressor ao agente denunciador e etc.

Acreditamos que a promoção da cultura de paz visa estimular transformações, indispensáveis para uma governabilidade com princípios de respeito e tolerância nas relações humanas e sociais. Por acreditarmos que podemos mudar e construir algo novo é que somos entusiastas dessa causa ativa, da luta que não fere, da batalha que não mata, da guerra que não cala. Portanto, desejamos a construção coletiva através das ações esportivas como estratégia de educação em saúde.

O presente trabalho propôs, como objetivo geral, identificar transformações sociais e pessoais decorrentes da participação no grupo de futebol educacional, Gaviões da Paz. Os objetivos específicos foram: a) A descrição das atividades desenvolvidas utilizando o esporte educacional; b) Conhecer a percepção dos participantes sobre as aprendizagens decorrentes da prática no grupo; c) Interpretar, nos relatos de diário de campo, detalhes técnicometodológicos da facilitação, além de transformações percebidas no grupo e nos indivíduos participantes; e d) Promover, através da pesquisa, espaços de avaliação do trabalho realizado com o esporte educacional.

\section{Metodologia}

Foi utilizada a abordagem qualitativa, por demonstrar sua contribuição no campo científico, voltando-se para o estudo do significado da experiência humana e social, das expressões da vida cotidiana, valores e crenças, atitudes, aspirações, etc. Esse método busca perceber os processos intersubjetivos que atravessam as relações sociais, captando através da linguagem comum o que motiva as ações humanas.

Foi realizado um grupo focal com os participantes do Gaviões da Paz. Essa técnica faz parte do processo qualitativo de investigação, tanto quanto análise de conteúdo que serviu para identificar os temas que compuseram as falas 
dos participantes. Outra ferramenta de produção de informações foi o diário de campo que, segundo Minayo (1999), são registros auxiliares na pesquisa, acomodando as percepções diárias tanto do participante como do ambiente, algo que nas entrevistas e grupos focais não se pode captar.

O grupo focal foi realizado com sete adolescentes, onde os critérios de inclusão para a amostra foram: morar no bairro Padre Palhano, ter vivenciado pelo menos oito meses nas atividades no grupo Gaviões da Paz, ter idade entre 7 e 17 anos. $O$ grupo focal foi realizado em uma sala de reunião dentro da unidade de saúde do Padre Palhano. O termo de consentimento livre e esclarecido foi assinado por um familiar responsável pelo jovem participante da pesquisa. Para a realização do grupo focal, houve a presença de um mediador, um relator, um observador e um pesquisador. Utilizamos um roteiro de entrevista semi-estruturada para motivar os diálogos do grupo. Estes diálogos foram registrados através do uso de gravador e transcritos posteriormente. A análise do material produzido foi feita através da análise de conteúdo, especificamente, da análise de enunciação. A forma de transcrever as falas utilizou uma decomposição dessas e mensagens, o que foi dito e não dito, pelas observações dos relatores de acordo com as técnicas da pesquisa.

Após a realização do grupo focal e esclarecimentos sobre o sigilo das informações e dos atores, houve um momento destinado para os adolescentes escolherem os nomes pelos quais desejavam ser chamados quando chegasse o momento de analisar as falas, e os codinomes escolhidos foram de jogadores de futebol: Benzemar, atacante da seleção francesa; Cristiano Ronaldo, português escolhido o melhor jogador do mundo em 2013; Messi, argentino três vezes escolhido o melhor do mundo; Neymar, atacante revelação do futebol brasileiro; Pelé, o nosso "rei do futebol"; Rogério Ceni, goleiro brasileiro recordista em fazer gols; e Ronaldinho, brasileiro considerado um dos melhores na atualidade.

A pesquisa aconteceu no período de fevereiro de 2013 a janeiro de 2014, sempre realizando levantamento bibliográfico, sendo que os últimos três meses foram destinados a realização do grupo focal, análise das falas e discussões. O último mês foi voltado às considerações finais e detalhes normativos.

\section{Discussão}

O grupo Gaviões da Paz efetivava-se através de atividades de jogo, de brincadeiras e de preparação físicoesportiva. Em todos os encontros, havia uma roda de conversa antes e depois dos momentos de atividade física, para avaliar e organizar as ações. Alguns temas de educação em saúde foram desenvolvidos nessas rodas de conversa, tais como: a questão da água; a alimentação; importância do alongamento e do aquecimento; o problema das drogas; a escola; a relação entre esporte e o processo saúde/doença; a importância do estudo; higiene pessoal; impostos; mulher; paz; polícia; puberdade; regras do futebol; respeito; saúde bucal; trabalho; violência e temas relacionados.

Nos encontros iniciais, eram frequentes as atitudes violentas no grupo, as "brincadeiras de bater" e um futebol violento, com muitas faltas. Jovens chorando após serem atingidos com força, entretanto, no registro do diário de campo do dia 15 de março de 2013, após inicialização do esporte educacional, consta que o comportamento do coletivo foi excelente, sem violência, "somente" uma expulsão, um ponto a melhorar, por já acreditarem que 
uma falta é agressão, e o esporte do grupo não permite esse tipo de atitude.

A Roda de Conversa era utilizada por compreendermos que, segundo Angelo (2006), tem grandes resultados na construção de ideias e diálogos problematizadores sobre temas geradores pertinentes à realidade sociocultural dos jovens. Nesses encontros, as crianças e adolescentes eram estimulados a problematizar as questões que surgiam e motivadas a uma apropriação do trabalho proposto. Antes de terminar as Rodas de Conversa, construíamos o que seria feito no dia, ou até mesmo em longo prazo, como visitas a outros espaços, participação e organização de torneios esportivos. Como já dito, o futebol era o esporte que sempre estava no planejamento das ações. Para Murad (2007), esse é um esporte universal e o que mais cresce no mundo. Para as crianças do Padre Palhano isso é verdade, estão unidos por esse esporte que é coletivo e tem pra eles significado.

Analisamos então, as falas de sete crianças que participaram do grupo focal. Para cada análise, definimos uma pergunta geradora, que serviu como tópico para melhor guiar nossas interpretações de forma que pudéssemos associá-la com a fala de autores que estudam o tema. Começamos, assim, com um tema amplo sobre futebol e depois apresentaremos as perguntas relacionadas ao grupo Gaviões da Paz.

\section{Como vocês se sentem na prática do futebol?}

Ao ser interrogado, Cristiano Ronaldo respondeu que se sentia "alegre". Segundo a autora Langsdorff (2009), a alegria é um sentimento, uma expressão emocional que remete a algo positivo, uma situação de felicidade. Já para Neymar, traz uma relevância de trabalho, por se sentir "profissional", o que é compreensível, segundo Elias et al. (1992), devido ao aumento de seriedade na prática esportiva, quando essa deixa de ser amadora e passa a ser profissionalizada. Estarjogando exige uma responsabilidade, portanto, uma sensação de profissionalismo, como os autores referem-se. $\mathrm{Na}$ perspectiva da sociologia do esporte, geralmente nas classes populares, o esporte é apropriado como uma possibilidade de ascensão social através da profissionalização. (ASSUMPÇÃO et al., 2010) Jogar futebol, para os participantes, também é uma forma de buscar mudar de vida através do trabalho.

Ronaldinho falou sobre uma de suas valências, dizendo que se sentia "rápido". Para Daros et al. (2008), a velocidade é uma das capacidades mais importantes do desempenho no desporto futebol. Além desses registros, tivemos: artilheiro, bom, equilibrado, focado, irado $e$ jogador.

\section{Vocês buscam, procuram algo ao jogar futebol?}

"Aprender a se equilibrar" foi a fala de Benzemar, quando indagado sobre seus desejos no grupo. Quanto a isso, Elias et al. (1992) ressaltam que o desporto tem uma tensão de grupo de forma organizada e que esse equilíbrio a que o garoto refere-se é um controle emocional. Podemos afirmar que o garoto pretende controlar-se perante as pressões existentes no jogo: a cobrança individual e coletiva pela vitória, o não responder às provocações do time adversário, uma vez que foi incentivado a se controlar, se equilibrar. Observamos, portanto, que o estímulo ao autocontrole, dentro das estratégias de promoção da saúde e da cultura de paz, foi um dos principais resultados alcançados pelo grupo. 
É significativa também, a fala de Pelé, "Acreditar e não desistir". Para Peixoto (2003), a persistência é uma característica da autoestima, uma atitude global, uma visão de si próprio, onde se implica um valor, um sentimento que se constitui como combustível. A personalidade de persistência do jovem foi reforçada nas aulas, através de estratégias de motivação e incentivos durante os jogos, bem como de conversas sobre exemplos de superação na vida cotidiana, no trabalho e no esporte.

O garoto Rogério Ceni expressou-se falando, " $a$ paz". Segundo Milani (2003), é possível ser autor da paz, a autora enfatiza que o homem que inventou a violência é capaz de estabelecer a paz. Como o grupo foi motivado nos encontros, a propor uma situação de harmonia, o garoto compreende que naquele espaço ele encontra a paz, com seus amigos, jogando bola, nas manhãs de terça e quintafeira.

As respostas foram variadas: "as técnicas do esporte futebol", "a valorização da cultura de paz" e etc. Entre elas, incluem-se: "Amizade", "Aprender mais", "Chutar com a perna esquerda", "Chutar direito", "Fazer gol", "Não causar confusão", "Não fazer falta", "Praticar o futebol sem violência" e "Ser um grande jogador". Observamos que existe uma procura pessoal para cada indivíduo, mas é evidente o esporte como motivador e propulsor dos encontros, que possibilitaram o desenvolvimento técnico, físico e ético-moral dos jovens participantes.

\section{O futebol, aqui no grupo, causa-Ihe alguma coisa?}

Para o garoto Messi, o grupo "causa amizade no bairro" e para a criança Pelé "causa paz". Portanto, demonstraramse harmonizados com a política de promoção da saúde que, segundo Galheigo (2008), apresenta um eixo específico para prevenção de violência e estímulo à cultura de paz. Nossas vivências progressivamente apontaram para a construção de uma coletividade amigável, a composição de laços de grupo, onde "jogar bola" é um ato valorizado e a violência não é tolerada.

Existe alguma diferença do futebol praticado aqui, comparado com os outros lugares em que você pratica?

Ronaldinho respondeu que "o futebol não é pesado, o nosso" e o Messi enfatizou "o nosso pratica a paz". Devemos ressaltar a presença, nas falas dos garotos, do pronome possessivo "nosso". Galheigo (2008) relembra-nos que no processo histórico da humanidade, a troca entre pessoas, grupos, clãs e nações constitui-se num mecanismo eficaz da garantia de períodos de paz.

Nosso grupo foi motivado pela valorização do coletivo, pois saber jogar com um grupo limitado tecnicamente é valorizar a potencialidade de cada um. Acreditando que todo coletivo tem possibilidades, foi necessário um arranjo de cada personagem para que fosse possível uma boa equipe. Não existe jogador ruim, nós ainda não encontramos um estilo no grupo, essa é uma visão disseminada entre nós.

\section{O que você busca no grupo?}

Temos uma sequência de falas interessantes. Cristiano Ronaldo falou: "diminuir a violência no nosso futebol". O Benzemar completou: "diminuir a violência no nosso bairro" e Rogério Ceni ampliou: "diminuir a violência na nossa cidade". O desejo de promoção da cultura de paz para grande parte dos indivíduos parece ser até enfadonho, mas não para esses jovens que escutam tiros e relatos de amigos e parentes mortos. 
Segundo Galheigo (2008), os profissionais da saúde pretendem trabalhar com a prevenção e com a construção de uma cultura de paz. Este é o nosso "Norte" no Padre Palhano e diante das falas dos jovens podemos visualizar um caminho possível, no sentido de construir uma sociedade menos agressiva e violenta, acreditando que somos arquitetos da nossa história, participando e valorizando o coletivo.

Para Cardoso et al. (2003), os jovens de escolas públicas relatam seus projetos de vida em conquistas humildes diante das possibilidades oferecidas no dia a dia. Esta temática, trabalho, apareceu entre nossos jovens. Benzemar falou: "arrumar um bom emprego no futuro melhor" e Pelé: "aprender, para no futuro ter uma boa vida". Acreditamos que o projeto de paz não se limita a não violência, e sim, à valorização de uma qualidade de vida com alimentação, educação, lazer, moradia e etc.

\section{Vocês aprenderam algo nestes encontros?}

Messi falou que aprendeu a "ser educado", Ronaldinho disse que aprendeu a "respeitar as pessoas" e Rogério Ceni "se comportar na escola." Segundo Cotrin (2000), são poucos os estudos sobre o comportamento entre jovens, limitados entre temáticas como gravidez, uso de anticoncepcionais e drogas. Já nossa abordagem aponta uma leitura sobre o comportamento dos jovens na escola e sociedade, respeitando os pares nos ambientes onde se encontram.

Essa abordagem sobre comportamento foi utilizada para facilitar a compreensão de direitos e deveres, em casa, na rua, na escola, no shopping, no teatro, no campo e etc. As rodas de conversa facilitaram a abordagem complexa sobre a paz. Especificamente sobre a escola, transcrevemos do diário de campo o dia em que conversamos sobre a atuação do Professor na escola e na sociedade, o respeito que deve ser dispensado aos docentes e trabalhadores escolares (auxiliares, merendeira, porteiro e etc).

Para Cotrin (2000), na sua pesquisa, os jovens engajam-se nos comportamentos que causam riscos à saúde. Portanto, nosso trabalho com o esporte educacional tende a ser educativo. Destacamos o relato de Cristiano Ronaldo quando indagado: "cuidar do corpo". Uma abordagem da higiene pessoal, que foi trabalhada no dia 21 de março de 2013, segundo o diário de campo, quando vários exemplos foram explicitados e dialogados para que os jovens passassem a se responsabilizar por sua saúde.

Para Rogério Ceni, a abordagem da cultura de paz: "Não praticar a violência", são aprendizagens que são valorizadas no grupo. No dia 18 de abril de 2013, fomos convidados, pelo Programa Esporte e Lazer na Cidade PELC, a participar de um evento esportivo onde as regras do futebol eram iguais as do grupo Gaviões da Paz: não poderia haver falta, pois o nosso grupo serviu de exemplo para o programa da Secretaria de Esporte do município.

"Aprender a confiar", "Cuidar bem da ferida", também foram aprendizados citados pelos participantes do grupo focal, sempre em sintonia com a proposta do grupo de jovens que deseja promover a paz, através dos encontros futebolísticos carregando o nome de Gaviões da Paz, sensibilizando os amigos e os transeuntes que moram no bairro ou apenas quando visitam.

Benzemar lembra de uma das aulas de música, quando ele fala que aprendeu a "Tocar tambor". As aulas de música foram utilizadas para que os jovens não ficassem esperando na ociosidade o momento de jogar. Os tambores foram utilizados como forma de entretenimento entre as partidas, assim criando um clima parecido com os do 
estádio de futebol, assimilando os sons dos tambores e o esporte praticado. No registro do dia 06 de abril de 2013, nos reunimos as 8 horas da manhã do sábado, tocamos em caminhada até o Centro de Referência a Assistência Social - CRAS, conversamos sobre sexualidade apoiados pelos profissionais do espaço, jogamos futebol e voltamos as 10:30 da manhã, caminhando, tocando os instrumentos e devolvendo para a escola, de onde são emprestados.

\section{O grupo tem algum objetivo?}

Para o jovem Pelé, o objetivo é "Aprender bons modos", como já foi citado anteriormente. Mas é sempre bom reforçar essa proposta, pois segundo os estudos de Cotrin (2000), movimentos agressivos com arma branca e arma de fogo não são eventos raros. Neymar disse que o objetivo é "não trazer violência, trazer coisas boas para o bairro". Fora os outros relatos, este traz a essência do coletivo que é repetida diversas vezes: a não violência, em prol de um contexto de paz.

\section{Quais são as regras do Gaviões da Paz?}

Nós construímos nossas regras nos primeiros encontros, conversando, e a principal delas Rogério Ceni citou: "não fazer falta". Segundo Elias (1982), existem desportos em que a violência é pouco nítida, mas não é o caso do futebol, onde vemos a falta fazer parte do jogo, fora as agressões na arquibancada entre torcedores, além das que ocorrem em campo entre jogadores. Para o autor, as relações em grupo e a construção de regras promovem uma civilização horizontal, diferentemente das opressoras que impõem. Nosso coletivo sempre dialogou a construção de regras, por ser parte da metodologia do esporte educacional e do método da roda de conversa. Assim, Ronaldinho respondeu quando questionado, uma das regras é "se controlar na regra do jogo".

\section{O Grupo da Paz construiu algo?}

Na sua pesquisa com jovens, Cotrin (2000) já sinalizava que os principais pontos contra a saúde dos jovens são: consumo de drogas, uso da violência e inconsequência no trânsito. Portanto, nossas abordagens sempre enfatizaram a saúde do coletivo e quando perguntaram o que tinham construído Benzemar respondeu: "Aprender a não fumar drogas" e a "limpar os dentes".

Na temática da cultura de paz, Ronaldinho colaborou com sua resposta quando disse o que tinha construído, " $a$ paz". Galheiro (2008) enfatiza a importância da presença de crianças e jovens nos fóruns de discussão sobre a violência e estratégias para promover a pacificação em territórios de conflito, como no nosso grupo: eles podem construir propostas baseados em suas realidades, trazendo significado para aquelas.

\section{O que é um gavião da paz?}

Para Elias (1992), a violência é um ciclo de medo e desconfiança entre grupos, já o nosso coletivo é consolidado em confiança e respeito, e nossos frutos estão na resposta de Ronaldinho e Neymar, respectivamente: "Um projeto que traz alegria para nosso bairro" e "Um projeto que traz paz". Nosso ciclo não promove o medo e a desconfiança, contrapondo o comportamento violento enfatizado pelo autor.

Na visão da autora Galheiro (2008), a postura do profissional da saúde quando propuser uma tecnologia 
de cultura de paz requer respeito às diferenças, e isso foi disseminado entre os jovens, com os quais estivemos dialogando e sempre exemplificando momentos onde o comportamento deve ser de compreensão, como é o caso da diversidade religiosa, sexual, política e etc. E para nossa alegria, quando indagamos sobre a pergunta Messi respondeu: "Saber respeitar".

Setores da educação, assistência social, saúde e segurança pública, segundo Galheiro (2008), são responsáveis pela cultura de paz e nossas ações partindo da promoção da saúde, no eixo da cultura de paz, condizem com as observações da autora, sendo reforçadas por Pelé quando respondeu definindo-os: "Um grupo formado por crianças que procura a paz no nosso bairro".

Para Helal (1990), a derrota e a vitória e seu uso metafórico no dialeto do esporte variam de cultura para cultura. Nesse sentido, entendemos a nossa derrota por sermos incapazes de resolver o problema da violência no mundo, ao passo que nos sentimos vitoriosos no jogo da vida, salvando as alegrias nas manhãs de sol intenso e vento ameno, ouvindo gritos de euforia, que soam como poesia, durante as partidas de futebol no bairro.

\section{Bate bola final}

Pudemos perceber, na experiência do grupo Gaviões da Paz, que o esporte educacional é uma ferramenta que promove a cultura de paz. Os jovens relataram que o nosso futebol promove amizades, reeduca, dentre outras falas. Nesse projeto, o professor de Educação Física, no processo de RMSF, pôde contribuir de modo significativo através das práticas esportivas, compartilhando com a equipe multiprofissional de saúde da ESF, saberes e práticas ligadas à cultura juvenil. Percebemos ainda aqui, a relevância desse profissional como mediador das ações de educação em saúde junto aos jovens.

O futebol deve ser valorizado e reconhecido como cultura, por fazer parte do cotidiano dessa comunidade. Assim, servirá de aprendizagem significativa nos momentos de educação em saúde, podendo alinhar diversos temas que o esporte pode agregar. Infelizmente, como parte dessa rotina, o futebol não é muito disseminado entre o gênero feminino, sendo um ponto a ser superado nas futuras intervenções em saúde. Percebemos, portanto, que o esporte educacional é uma importante ferramenta de atuação dentro do contexto da ESF, constituindo-se como tecnologia leve em saúde, capaz de promover relações efetivas e afetivas de aproximação entre serviços de saúde e população jovem. Destaca-se, nesse aspecto, o papel da Educação Física, como profissão mediadora da aproximação entre as equipes multiprofissionais e usuários.

Concluímos, então, que devido à realidade local e suas potencialidades, são necessárias políticas públicas que continuem a promover paz no território. As ações realizadas obtiveram um êxito relativo, como a pesquisa buscou demostrar, trazendo importantes reflexões para pensar as práticas de promoção da saúde e da cultura de paz, através da ESF e RMSF. No entanto, as experiências exitosas vivenciadas permaneceram conflitando com assassinatos, drogas, medo, mortes, tiros e etc. Pudemos perceber que o esporte foi uma arma para resistir à cultura da violência. Percebemos que ele educa e muito mais, de modo que assim se faz, uma possibilidade de luta em paz, sem violência, com o Gaviões da Paz. 


\section{Referências}

ANGELO, A. A pedagogia de Paulo Freire nos quatro cantos da educação da infância. In: I CONGRESSO INTERNACIONAL DE PEDAGOGIA SOCIAL, 1., 2006, Faculdade de Educação, Universidade de São Paulo, Disponível em: <http://www. proceedings.scielo.br/scielo.php?script=sci_arttext\&pid=M SC0000000092006000100001\&lng $=e n \& n r m=a b n>$. Acesso em: 10 de Fevereiro de 2014.

ASSUMPÇÃO, L.O.T.; SAMPAIO, T.M.V.; CAETANO, J.N.N.; CAETANO JÚNIOR, M.A., SILVA, J.V.P. Temas e questões fundamentais na Sociologia do esporte. In: Revista Brasileira Ciência e Movimento. v.18, n.2, p.92-99, 2010.

BRASIL. Ministério da Saúde. Secretaria de Vigilância em Saúde. Política Nacional de Promoção da Saúde, Brasília: Ministério da Saúde, 2006. Disponível em: <http://portal. saude.gov.br/portal/arquivos/pdf/PNPS2.pdf>. Acesso em: 28 mar 2013.

BRASIL. Ministério da Saúde. Secretaria de Atenção à Saúde. Núcleo Técnico da Política Nacional de Humanização. HumanizaSUS: Documento base para gestores e trabalhadores do SUS / Ministério da Saúde, Secretaria de Atenção à Saúde, Núcleo Técnico da Política Nacional de Humanização. 4ed. Brasília: Editora do Ministério da Saúde, 2008a. 72p.

BRASIL, Ministério da saúde. Impacto da violência na saúde da criança e adolescente: Prevenção da violência e promoção da cultura de paz. Brasilia, DF, 2008b 12p. Disponível em: <http://www.feim.org.ar/pdf/blog_ violencia/afc_cartilha_a5b.pdf $>$. Acesso em: 28 de abril de 2013.

CARDOSO, C.P.; COCCO, M.I.M. Projeto de vida de um grupo de adolescentes a luz de Paulo Freire. In: Rev. Latinoam Enfermagem, nov./dez., v.11, n.6, 2003, p.778-785. Disponível em: <http://www.scielo.br/pdf/rlae/v11n6/ v11n6a12.pdf>. Acesso em: 15 jan 2014.

COTRIN, B.C.;CARVALHO,C.G.;GOUVEIA, N. Comportamento de saúde entre jovens estudantes das redes públicas e privada da área metropolitana do estado de São Paulo. In: Rev. Saúde Pública, v.34, n.6 p.636-645, 2000. Disponível em: <http://www.scielosp.org/pdf/rsp/v34n6/3579.pdf>. Acesso em: 15 jan 2014.

ELIAS, N.; DUNNING, E. A busca da excitação. Coleção memória e sociedade. Tradução por Maria Manuela Almeida e Silva. Lisboa (Portugal): DIFEL, 1992.

DAROS, L.B.; OSIECKI, R.; DOURADO, A.C.; STANGANELLI, L.C.R.; FORNAZIERO, A.; MONTANHOLI, F.A. Análise comparativa das características antropométricas e de velocidade em atletas de futebol de diferentes categorias. In: Revista de Educação Física, UEM, Maringá, v.19, n.1, ano 1, trim. 2008.

GALHEIGO, S.M. Apontamentos para se pensar ações de prevenção à violência pelo setor saúde. Revista Saúde Soc. São Paulo, v.17, n.3, p.181-189, 2008. Disponível em: <http://www.scielo.br/pdf/sausoc/v17n3/18.pdf>. Acesso em: 15 jan 2014.

GÁSPARI, J.; SCHWATRZ, G. Adolescência, Esporte e Qualidade de Vida. Motriz Jul-Dez 2001, v.7, n.2, p.107113. Disponível em: <http://www.rc.unesp.br/ib/efisica/ motriz/07n2/gaspari.pdf> Acesso em: 28 ma 2013.

HALPERN, R.; FIGUEIRAS, A. Influências ambientais na saúde mental da criança. Jornal de Pediatria, v.80, n.2(Supl), 2004. Disponível em: <http://www.scielo.br/pdf/jped/v80n2s0/ v80n2Sa12.pdf>. Acesso em: 28 mar 2013. 
HELAL, R. O que é sociologia do esporte. Primeira edição. São Paulo (SP): Brasiliense, 1990. 80p.

MERHY, E.E. Saúde: a cartografia do trabalho vivo. São Paulo: Hucitec, 2007. 189p.

MILANI, F.M.;JESUS, R.C.D.P.(Org.) Cultura de Paz: estratégia, mapas e bússolas. Salvador: INPAZ, 2003. 356p. Disponível em:<http://systembrasil.com.br/pazeando/downloads/ livropnv/PNV-CulturadePaz-EstrategiasMapaseBussolas. pdf\#page=97> Acesso em: 28 abr 2013.

MINAYO, M.C.S. O desafio do conhecimento: Pesquisa Qualitativa em Saúde. 6ed. São Paulo: Hucitec; Rio de Janeiro: Abrasco, 1999. 269p.

MINAYO, M.C.S. SOUZA, E.R. Violência e saúde como um campo interdisciplinar de ação coletiva. História, Ciência e Saúde - Manguinhos. v.IV, n.3, p.513-531, nov.1997fev.1998. Disponível em: <http://www.scielo.br/pdf/hcsm/ v4n3/v4n3a06> Acesso em: 28 abr 2013.

MURAD, M. A violência e o futebol: Dos estudos clássicos aos dias de hoje. 1ed. Rio de Janeiro: FGV, 2007. 196p.

LANGSDORFF, R. 13 capítulo: Experiências lúdicas no cotidiano escolar. Projeto brinquedoteca: espaço de formação, pesquisa e extensão. Adelaide Rezende de Sousa (org.), Rio de Janeiro, 2009. p79-85. Disponível em:<http:// www.projetobrinquedoteca.com.br/arquivos_download/ Oficinas_Ludicas_RJ.pdf> Acesso em: 15 jan 2014.

OLIVEIRA, V.M. O que é Educação Física. Editora brasiliense. 8ed. São Paulo: Brasiliense, 1990. 111p.

PEIXOTO, F.J.B. Auto-Estima, Autoconceito e Dinâmicas relacionais em contexto escolar: Estudos das relações entre auto-estima, autoconceito, rendimento acadêmico e dinâmicas relacionais com a família e com pares em alunos do 7으, 9o e 11을 anos de escolaridade. Braga, 2003. 419p. Tese (Doutorado em Psicologia), Instituto de Educação e Psicologia, Universidade do Minho, 2003.

PINTO, C. Esporte Educacional: uma possibilidade de restauração do esporte. R. Min. Educ. Fís., Viçosa, v.17, n.2, p.115-122, 2009. Disponível em:<http://www. revistamineiradeefi.fv.br/artigos/arquivos/9e885b1d6177c 4d1183b9e5aaca8fbd.pdf> Acesso em: 28 mar 2013.

SOBRAL. Secretaria Municipal de Ação Social e Saúde. Sistema de Vigilância Agravos e Notificação, SIVAN, Vigilância Epidemiológica do município de Sobral, dados do ano de 2012. SANCHES, S.; RUBIO, K. A prática esportiva como ferramenta educacional: trabalhando valores e a resiliência. Rev. Educação e pesquisa, São Paulo, v.37, n.4, p.825-842, dez. 2001. Disponível em: <http:/educa.fcc.org. br/pdf/ep/v37n04/v37n04a10.pdf> Acesso em: 28 mar 2013.

STIGGER, M.P. Educação Física, Esporte e Diversidade. São Paulo: Autores Associados, 2005.

TUBINO, M. O que é esporte. São Paulo: Brasiliense, 1993. $68 p$.

Estudos brasileiros sobre o esporte: ênfase no esporte-educação. Maringá: Eduem, 2010.163 p. Disponível em: <http://www.listasconfef.org.br/arquivos/ Livro_Esporte.pdf> Acesso em: 28 mar 2013. 


\title{
PRÁTICAS CORPORAIS E PROMOÇÃO DA SAÚDE EM UM GRUPO DE MULHERES DA ESTRATÉGIA SAÚDE DA FAMÍLIA
}

\author{
Manoel Artur Ferreira Sousa Filho \\ Ana Helena Araújo Bomfim Queiroz \\ André Luis Façanha da Silva \\ Fátima Café Ribeiro dos Santos
}

\section{Introdução}

Ao longo da história, a atenção à saúde no país tem investido na efetivação de políticas de promoção da saúde que venham a garanti-la como um direito do cidadão e um dever do Estado. Grandes esforços estão sendo feitos na construção de um modelo de atenção à saúde que priorize ações de melhoria da qualidade de vida dos sujeitos e coletivos. (BRASIL. MINISTÉRIO DA SAÚDE, 2006a)

A constituição de 1988, artigo 196, define que a:

[...] saúde é um direito de todos e um dever do Estado, garantido mediante políticas sociais e econômicas que visem à redução do risco de doenças e de outros agravos e ao acesso universal e igualitário às ações 
e serviços para a sua promoção, proteção e recuperação. (BRASIL. MINISTÉRIO DA SAÚDE, 1988)

Desta forma, na base de criação do Sistema Único de Saúde (SUS) encontra-se o conceito ampliado de saúde, a necessidade de criar políticas públicas para provê-la e o imperativo da participação social na construção do sistema e das políticas de saúde. Compreende-se o SUS como o conjunto de ações e serviços de saúde oferecidos por órgãos e instituições públicas, da administração direta e indireta das fundações mantidas pelo poder público, sendo permitida a oferta pela iniciativa privada em caráter complementar. (TEIXEIRA, 2009)

O tema promoção da saúde entrou em destaque no final da década de 1970, quando a Organização Mundial de Saúde (OMS) apresentou uma estratégia de promoção e prevenção de doenças conhecida como Saúde para todos no ano 2000. O primeiro grande evento que discutiu sobre esse assunto foi a 1a a Conferência Mundial de Promoção da Saúde, que ocorreu em Ottawa, no Canadá, no ano de 1986 , onde foi produzido um documento conhecido como A Carta de Ottawa, que propõe a promoção da saúde como um processo que visa capacitar as pessoas para aumentar o controle do Estado sobre a qualidade de vida e saúde, apoiando-se no desenvolvimento pessoal e social, por meio da divulgação de informações, educação para a saúde e intensificação das habilidades vitais. (BRASIL. MINISTÉRIO DA SAÚDE, 2002)

De acordo com essa Carta, a expressão promoção da saúde corresponde ao processo de capacitação da comunidade para atuar na melhoria de sua qualidade de vida e saúde, incluindo uma maior participação no controle desse processo, a fim de atingir um estado de completo bem-estar físico, mental e social. (PINTO, 2012) Nesse sentido, a OMS considera a promoção da saúde eficaz, ao acarretar mudanças nos determinantes da saúde, os quais podem ser tanto os fatores que estão sob o controle do indivíduo, como estilos de vida e condutas, quanto os fatores externos, relativos às condições econômicas, sociais, ambientais e à prestação de serviços.

O Ministério da Saúde, através da Portaria n. 687, de 30 de março de 2006, resolveu aprovar a Política Nacional de Promoção da Saúde (PNPS), num esforço para o enfrentamento dos desafios de produção da saúde em um cenário sócio-histórico cada vez mais complexo e que exige a reflexão e qualificação contínua das práticas sanitárias e do sistema de saúde. O objetivo geral dessa política é promover a qualidade de vida e reduzir vulnerabilidade e riscos à saúde relacionados aos seus determinantes e condicionantes, modos de viver, condições de trabalho, habitação, ambiente, educação, lazer, cultura, acesso a bens e serviços essenciais. (BRASIL. MINISTÉRIO DA SAÚDE, 2006a)

A PNPS tem como uma de suas áreas estratégicas "Práticas Corporais/Atividade Física", que traz orientações com vistas às seguintes iniciativas: Ações na rede básica de saúde e na comunidade; ações de aconselhamento/ divulgação; ações de intersetorialidade e mobilização de parceiros; ações de monitoramento e avaliação. Essas ações em si trazem sugestões de técnicas para efetivação das Práticas Corporais/Atividade Física, de forma a garantir, disseminar, educar, acompanhar, monitorar e avaliar as ações que visem a intersetorialidade no cenário da Atenção Básica à Saúde.

Segundo Fraga et al. (2009), o termo práticas corporais passa a ser utilizado nas literaturas a partir de 1996. Na verdade, o termo não possui uma conceituação explícita. Podemos afirmar que o referido termo vem sendo 
empregado por vários campos do conhecimento, sendo que, dentre esses, a Educação Física é o que o utiliza com maior frequência.

Pensar os sentidos das práticas corporais na sociedade atual é considerar os diversos discursos produzidos no meio em que vivemos. (FREITAS, 2006) Tal ação reflexiva remete à problemática da relação entre educação física e saúde que se tem correntemente vinculado. (SANTOS, 2008) Com base nessas observações, Moretti (2009) destaca a importância de pensar a Educação Física no serviço público de saúde, não só por ampliar seu campo de intervenção, mas principalmente para rever a forma de eleger, tratar seus conteúdos e de lidar com os sujeitos quando a questão é saúde.

No campo da Educação Física, as práticas corporais vêm sendo valorizadas e estabelecem relação com as ciências humanas e sociais, pois aqueles que dialogam com as ciências biológicas e exatas operam com o conceito de atividade física. (LAZZAROTTI FILHO et al., 2010)

Assim, Lazzarotti Filho et al. (2010) definiram o termo práticas corporais como sendo: manifestações culturais que enfocam a dimensão corporal, que buscam superar a fragmentação identificada na constituição do ser humano e denotam uma crítica à forma de organização da vida contemporânea e seus desdobramentos no corpo. Apresentam ainda, finalidades como promoção da saúde, educação para a sensibilidade, para a estética, para o desenvolvimento do lazer e para o cuidado com o corpo.

Outra dimensão que as práticas corporais têm adotado no cotidiano das unidades de saúde é a sua medicalização. Para Fraga (2009), esse é um processo que se evidencia na responsabilização cada vez maior dos sujeitos pela sua própria saúde, através da disseminação de comportamentos a serem evitados, como por exemplo, comer mal, não praticar exercícios físicos, não dormir, exporse ao sol, fumar, entre outras tantas interdições prescritas por uma ordem médica que, em nome da longevidade, "cadaveriza a vida".

Assim, as práticas corporais no campo da saúde pública, para a materialização do conceito ampliado de saúde, exigem do profissional Professor de Educação Física uma postura ética, crítica e política em defesa dos princípios do SUS, visando a superação do trabalho morto para o trabalho vivo ${ }^{1}$ em ato, com o uso racional de tecnologias em saúde: as duras, leve-duras e a maximização das leves. ${ }^{2}$ (MERHY, 2005)

$\mathrm{Na}$ perspectiva do trabalho vivo e das tecnologias leves em saúde, as práticas corporais configuram-se como exemplo dessas tecnologias, com vistas à escuta qualificada, ao acolhimento e ao vínculo de dimensões importantes e potentes para produzir reflexões necessárias sobre o processo de saúde-doença e o cuidado na relação entre o agente produtor e o consumidor, esse último que busca a saúde enquanto valor de uso útil e significativo para estar

1 Para Merhy "o trabalho em saúde não pode ser globalmente capturado pela lógica do trabalho morto, expresso nos equipamentos e nos saberes tecnológicos estruturados, pois o seu objeto não é plenamente estruturado e suas tecnologias de ação mais estratégicas se configuram-se em processos de intervenção em ato, operando como tecnologias de relações, de encontros de subjetividades, para além dos saberes tecnológicos estruturados, comportando um grau de liberdade significativo na escolha do modo de fazer produção em saúde." (MERHY, 2002, p.49)

2 A classificação elaborada por Merhy referente às tecnologias em saúde são: "leves (como no caso das tecnologias de relações do tipo produção de vínculo, autonomização, acolhimento e gestão como uma forma de governar processos de trabalhos); leve-duras (como, no caso, os saberes bem estruturados que operam no processo de trabalho em saúde, como a clínica médica, a clínica psicanalítica, a epidemiologia, o taylorismo, o fayolismo) e duras (como no caso de equipamentos tecnologias do tipo máquinas, normas, estruturas organizacionais)." (MERHY, 2002, p.49) 
no mundo e poder vivê-lo. O interesse pelo referido estudo surgiu da inquietação de saber como as participantes do Grupo da $\mathrm{Paz}^{3}$ relacionam as práticas corporais com a melhoria da sua saúde, uma vez que, durante as atividades, as mulheres faziam referência a essa transformação. Daí surgiu o seguinte questionamento: Qual a relação percebida pelas participantes do Grupo da Paz entre as práticas corporais e a promoção da saúde?

O estudo tem como objetivo analisar a relação entre práticas corporais e promoção da saúde em um grupo de mulheres da Estratégia da Saúde da Família (ESF), do território do bairro Terrenos Novos, em Sobral (CE). Para tal, buscou-se verificar as mudanças nos valores antropométricos e identificar as transformações no quadro psicossocial das participantes do Grupo da Paz, de acordo com o formulário de Avaliação Corporal Integrada.

Neste sentido, o presente estudo tem o intuito de colaborar para uma percepção mais ampliada acerca da relação entre práticas corporais e promoção da saúde, rompendo com a lógica biomédica, de modo a não desprezar as várias dimensões em que os participantes estão introduzidos.

\section{Metodologia}

A pesquisa apresenta uma abordagem quantitativa. O estudo é de natureza descritivo-longitudinal. A pesquisa descritiva caracteriza-se como estudo que procura determinar opiniões ou projeções futuras nas respostas obtidas de uma determinada população. (THOMAS, 2001)

\footnotetext{
3 Grupo da Paz é um grupo de práticas corporais composto por mulheres usuárias do CSF, onde são realizadas diversas atividades que visam a promoção da saúde.
}

De acordo com o mesmo autor, o estudo longitudinal é um método de pesquisa que visa analisar as variações nas características dos mesmos elementos amostrais (indivíduos, grupos, organizações, etc.) ao longo de um determinado período de tempo. Os dados são colhidos primeiramente no início do estudo e podem então, ser recolhidos diversas vezes ao longo de todo o andamento do processo. Por meio dos estudos longitudinais, os pesquisadores podem identificar determinadas mudanças na população estudada.

A investigação foi realizada no município de Sobral, localizado na zona norte do estado do Ceará, com população estimada de 197.663 habitantes (IBGE 2010), sendo a quinta cidade mais povoada do Estado e a segunda maior do interior.

O cenário do estudo tem como foco o território dos Terrenos Novos, que teve sua criação originada pela lei municipal n. $.013 / 82$, de 1 o de dezembro de 1982. Inicialmente, chamava-se Cidade Dr. José Euclides. (BONFIM, 2008) Segundo dados do Sistema de Informação da Atenção Básica (SIAB, 2014), obtidos em janeiro de 2014, a população do bairro seria de 14.525 habitantes, no qual se destaca uma predominância da população feminina entre 20 a 39 anos, ou seja, que estão na faixa etária economicamente ativa.

As análises ocorreram com os dados do Grupo da Paz, que é composto por 45 mulheres na faixa etária entre 20 a 67 anos, usuárias do Centro de Saúde da Família (CSF), onde são realizadas diversas atividades que visam à promoção da saúde, como a ginástica comunitária, a ginástica localizada, o fortalecimento muscular, a dança, o alongamento, o relaxamento, atividades lúdicas e dinâmicas de grupo, bem como momentos de educação em saúde, como rodas de conversa sobre temas escolhidos pelas participantes, além 
do "Café com Gentileza" ${ }^{4}$, tendo as práticas corporais como foco principal. As atividades do grupo acontecem todas as terças e quintas-feiras, às 7 horas da manhã, na Associação Comunitária Benedito Tonho, situada no território dos Terrenos Novos.

A população do estudo é constituída pelas participantes do referido grupo de práticas corporais que são acompanhadas pelo CSF dos Terrenos Novos. A atividade surgiu com o apoio da equipe da Residência Multiprofissional em Saúde da Família (RMSF) como uma estratégia de autogestão do cuidado e de promoção da saúde. (SOUSA FILHO, 2012) Os encontros são facilitados pelos profissionais das categorias de Educação Física, Nutrição e Serviço Social da RMSF.

Como instrumento de coleta de dados, utilizou-se o Sistema de Informação e Monitoramento da Avaliação Corporal Integrada (SIMACI), que é um conjunto de dados originados sobre fatores demográficos, socioeconômicos, antropométricos, comportamentais, nutricionais, de saúde mental e fatores de proteção e risco à saúde, organizados e informatizados para avaliação e monitoramento dos resultados das ações coletivas sistemáticas em saúde realizadas pelos profissionais; bem como, a elaboração de indicadores para análise e avaliação dos processos e resultados, na qualificação das atividades desenvolvidas pelos profissionais como uma tecnologia de trabalho na ESF. (SOBRAL, 2010)

\footnotetext{
${ }^{4} \mathrm{O}$ "Café com Gentileza" é o nome que se dá para uma atividade realizada no Grupo da Paz, que ocorre toda 1. a terça-feira do mês. Cada participante traz de sua residência um alimento para oferecer ao grupo. O momento configura-se como um espaço de educação em saúde, onde as mulheres irão discutir sobre diversas temáticas escolhidas por elas próprias. Tal momento é de suma importância, uma vez que fortalece os vínculos sociais, pois elas compartilham vivências e constroem uma rede de apoio tecida a partir de suas potencialidades e singularidades.
}

A ação de construir um instrumento integrado de avaliação corporal, nutricional, sociodemográfica, bem como de fatores de risco/proteção à saúde dos usuários, para prevenção e assistência das Doenças e Agravos Não Transmissíveis (DANTs), possibilita a construção de indicadores que possam captar a situação epidemiológica dos participantes dos grupos e seu monitoramento. (SOBRAL, 2010)

Para Silva (2009), esse procedimento passou a fazer parte dos serviços de saúde, com agendamentos prévios de usuários encaminhados por outros profissionais da equipe de Saúde da Família orientados para fazer parte do programa de atividade física.

Foi realizada uma Avaliação Corporal Integrada, no final de 2012, com 29 mulheres do referido grupo. A proposta foi realizar, ao final do processo da Residência, uma reavaliação/monitoramento com as mesmas participantes e a compararação dos resultados, avaliando a relação das práticas corporais com a promoção da saúde, a fim de investigar as mudanças ocorridas.

Para inclusão nessa pesquisa, foram selecionadas as mulheres que participaram da Avaliação Corporal Integrada feita anteriormente e que continuaram participando ativamente das atividades do grupo.

A avaliação inicial foi realizada no final de 2012 e a reavaliação/monitoramento ocorreu no período de 20 de janeiro a 04 de fevereiro de 2014. O professor de Educação Física que atua na RMSF, um dos facilitadores do grupo, foi responsável pela coleta de dados das duas avaliações, a qual se deu por meio de uma entrevista de avaliação que utilizou o instrumento Avaliação Corporal Integrada/ Monitoramento. Vale ressaltar que os dois instrumentos de avaliação não são iguais, eles diferem em alguns questionamentos específicos. 
Para constituição dos dados sociodemográficos, foram utilizados dados pessoais como a faixa etária, estado civil, cor/etnia, escolaridade, situação ocupacional etc. $\mathrm{Na}$ avaliação psicossocial, foram feitas perguntas contendo algumas opções relativas à saúde, comportamento e nível de satisfação da capacidade de desempenhar as atividades do dia a dia. Com relação aos dados antropométricos, foram realizadas as seguintes aferições: 1) Índice de Massa Corporal (IMC): Logo após o levantamento, foram realizadas as respectivas anotações das variáveis peso e altura das avaliadas. Essas variáveis foram posteriormente tratadas pelo método da avaliação do IMC, que é a relação entre o peso e a altura de um indivíduo, traduzida pelo quociente entre o peso em quilos e o quadrado da altura em metros, $\left[\mathrm{IMC}=\right.$ Peso $(\mathrm{kg}) /$ Altura $\left.\left(\mathrm{m}^{2}\right)\right]$. Tais dados foram distribuídos dentro de uma tabela de classificação do estado nutricional, de acordo com o protocolo estabelecido pelo SISVAN (BRASIL. MINISTÉRIO DA SAÚDE, 2008); 2) Circunferência da cintura: Essas medidas foram analisadas e os resultados foram qualificados dentro de uma tabela de classificação proposta pela Organização Mundial da Saúde. (WHO, 2000)

A análise dos dados coletados foi processada em consonância com a estatística descritiva, a qual foi baseada em tabelas de classificação, com auxílio do software Excel for Windows.

Quanto à responsabilidade pela guarda e custódia das informações, foi estabelecido o compromisso por parte dos pesquisadores, representantes da Secretaria da Saúde pela Comissão Científica, por meio de declaração de instituição coparticipante, de coletar e utilizar os dados, resguardando os direitos assegurados pela Resolução n.o 466, de 12 de dezembro de 2012, do Conselho Nacional de Saúde, especialmente no que tange à garantia de privacidade, confidencialidade, anonimato e não utilização das informações em prejuízo dos envolvidos ou de terceiros, bem como do emprego dos dados somente para fins previstos nesta pesquisa.

\section{Análise e discussão dos resultados}

Da primeira avaliação participaram 29 mulheres e foram reavaliadas 17 delas, seguindo o critério de inclusão que era o de terem participado da avaliação inicial e estarem participando ativamente das atividades do grupo.

Percebeu-se que a população que participa do grupo é formada por pessoas do ciclo de vida adulta e idosa, com faixa etária entre 25 a 67 anos e com idade média de 42,5 anos. Sendo $47,1 \%$ entre 20 e 39 anos, $47,1 \%$ entre 40 e 59 anos e apenas $5,9 \%$ com 60 ou mais anos.

Segundo a cor/etnia, 76,5\% das mulheres consideramse pardas, 5,9\% pretas, 5,9\% brancas, 5,9\% amarelas e 5,9\% não sabem. A população parda foi a que mais aumentou na última década (16,9 milhões). Atualmente, são 82.277.333 habitantes que se declaram pardos, correspondendo a $43,1 \%$ da população brasileira, quase igualando com a população de brancos (47,7\%). (IBGE, 2010)

Quanto ao estado civil das participantes do grupo, $76,5 \%$ são casadas, $11,8 \%$ são solteiras e $11,8 \%$ são separadas. Segundo o nível de escolaridade, $41,2 \%$ não concluíram o ensino fundamental, 29,4 cursaram o ensino fundamental completo, $17,6 \%$ das participantes concluíram o ensino médio e $11,8 \%$ tem o ensino médio incompleto.

De acordo com a situação ocupacional, 52,9\% das mulheres estão desempregadas, 23,5\% têm emprego informal e $23,5 \%$ são beneficiárias do Programa Bolsa Família. 
O grupo é composto por $88,2 \%$ de mulheres moradoras do bairro dos Terrenos Novos e $11,8 \%$ de outros bairros circunvizinhos (Vila União e Junco). O fato de existirem usuárias de outros bairros no Grupo da Paz está relacionado a um número insuficiente de professores de Educação Física nas atividades de práticas corporais vinculadas ao Sistema de Saúde de Sobral.

A Figura 1 apresenta uma comparação da classificação do IMC das participantes do Grupo da Paz, com relação às duas avaliações realizadas.

Figura 1 - Comparativo da classificação do Índice de Massa Corporal (IMC) das participantes do Grupo da Paz do território dos Terrenos Novos em Sobral (CE).

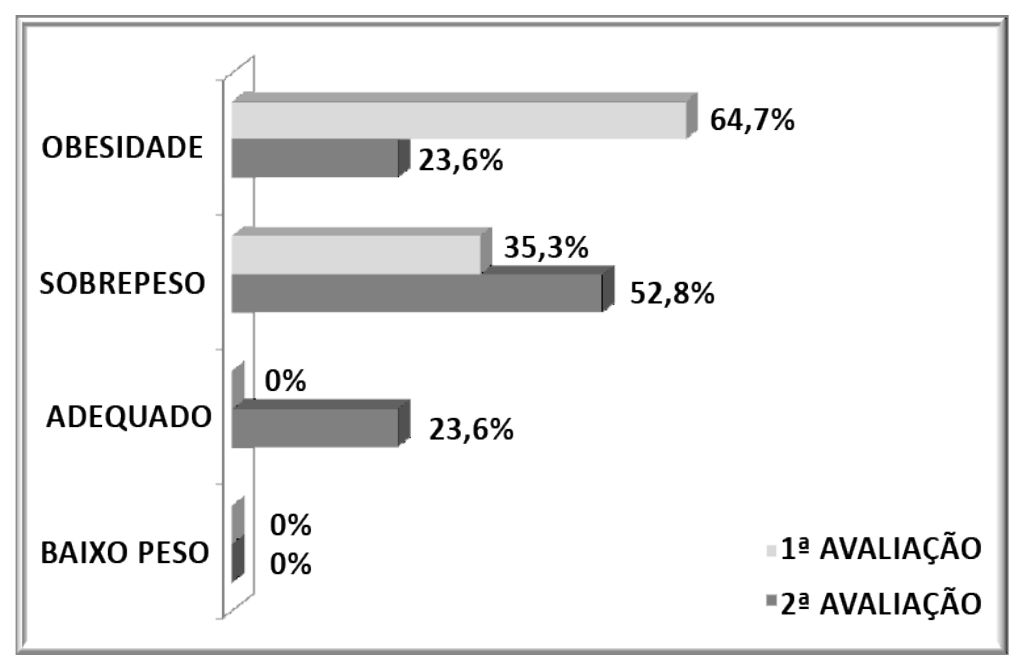

Fonte: Sobral. Secretaria Municipal de Saúde, 2014.

Observa-se que, na 1. a avaliação, $64,7 \%$ das mulheres avaliadas encontravam-se com obesidade, já na 2. a avaliação esse índice foi diminuído para $23,6 \%$. Com relação à faixa de sobrepeso, $35,3 \%$ das mulheres encontravam-se nesta categoria na 1. avaliação, porém, efetivada a 2. a avaliação, esse indicador passou para $52,8 \%$, assim, confirmou-se que algumas mulheres migraram da categoria obesidade para a de sobrepeso. Outro fato relevante que mostra a figura 1 é que nenhuma das participantes estava dentro da faixa adequada/eutrófico na 1a avaliação e que, de acordo com a 2 a avaliação, $23,6 \%$ delas passaram a fazer parte desse conceito.

Em relação ao IMC, percebe-se que houve uma melhora significativa das mulheres que participaram do referido estudo. De acordo Guimarães (2008), esse índice poderá influenciar na qualidade de vida relacionada com a saúde da mulher, envolvendo particularidades físicas e psicológicas. Geralmente, o aumento de peso encontra-se associado a uma redução da melhoria da saúde.

A prevenção e o diagnóstico precoce da obesidade são importantes aspectos para a promoção da saúde, não só por ser um fator de risco importante para as DANTs e outras doenças, mas também por interferir diretamente na melhoria da saúde. (BRASIL, 2006b) Assim, diversas ações são realizadas no Grupo da Paz, trabalhando a promoção da saúde, visando a vigilância e o diagnóstico precoce da obesidade das participantes.

De acordo com Silva (2009), cabe ao profissional de Educação Física, através da ação educativa, enfatizar a importância do controle e do acompanhamento clínico periódico, com a contribuição da avaliação corporal integrada e seu monitoramento.

A Figura 2 traz um comparativo da classificação da circunferência da cintura (CC) do Grupo da Paz, com relação às duas avaliações já realizadas. 
Figura 2 - Comparativo da classificação da circunferência da cintura (CC) das participantes do Grupo da Paz do território dos Terrenos Novos em Sobral (CE).

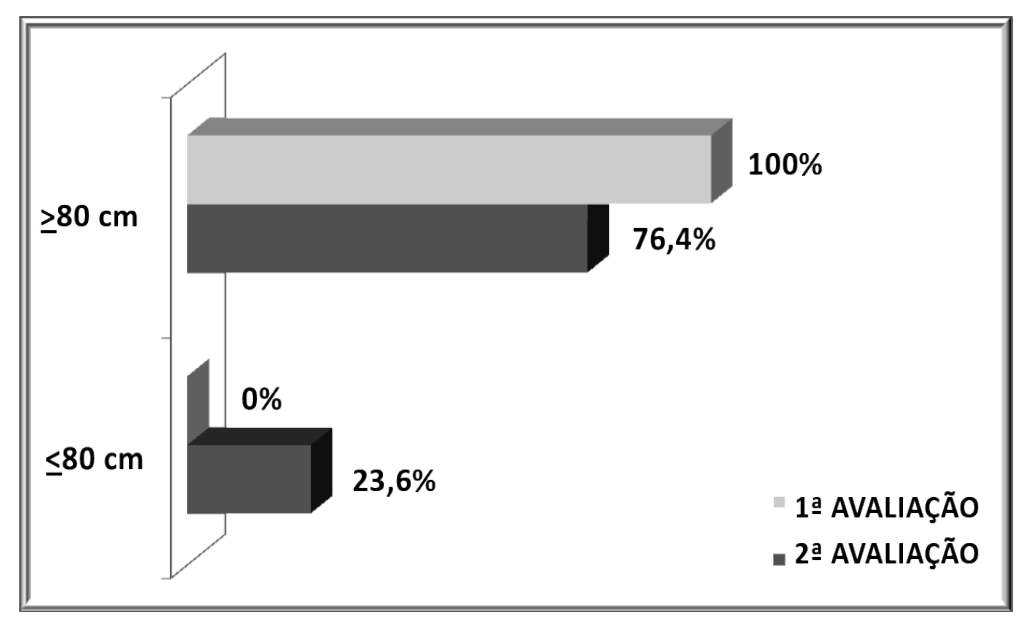

Fonte: Sobral. Secretaria Municipal de Saúde, 2014.

O resultado da aferição da circunferência da cintura (CC) vem ratificar os dados discutidos anteriormente no tocante ao IMC. Obteve-se uma redução, comparando as avaliações anteriores. Na 1a avaliação, havia $100 \%$ das mulheres com risco elevado para doenças cardiovasculares e, de acordo com a 2a avaliação, esse número foi reduzido para $76,4 \%$. Isso implica dizer que $23,6 \%$ saíram de uma categoria de risco e foram para uma melhor condição de saúde.

Santos (2006) observou que práticas corporais orientadas e associadas à ação conjunta de uma equipe multiprofissional tem um efeito significativo na redução da obesidade, da circunferência abdominal e no controle de peso corporal mantido por período prolongado, diferente da utilização de medicamentos ou dietas, onde há redução imediata de peso, porém não há uma manutenção. Essas ações têm potencializado a mudança do modelo médico assistencial com ampliação de espaço de cuidado e de intervenção de outros profissionais em parceria com os professores de Educação Física. (SILVA, 2009)

Segundo Zamai e Bankoff (2010), as práticas corporais são alguns dos elementos fundamentais para a aquisição e manutenção de melhoria da qualidade de vida. Desta forma, as participantes do Grupo da Paz estão seguindo a trajetória adequada em busca desse objetivo bastante almejado por todos.

A figura 3 demonstra as duas avaliações e relaciona o comparativo da situação da saúde das participantes do Grupo da Paz no tocante a como elas próprias consideraram estar a própria saúde.

Figura 3 - Comparativo da situação da saúde das participantes do Grupo da Paz do território dos Terrenos Novos em Sobral (CE).

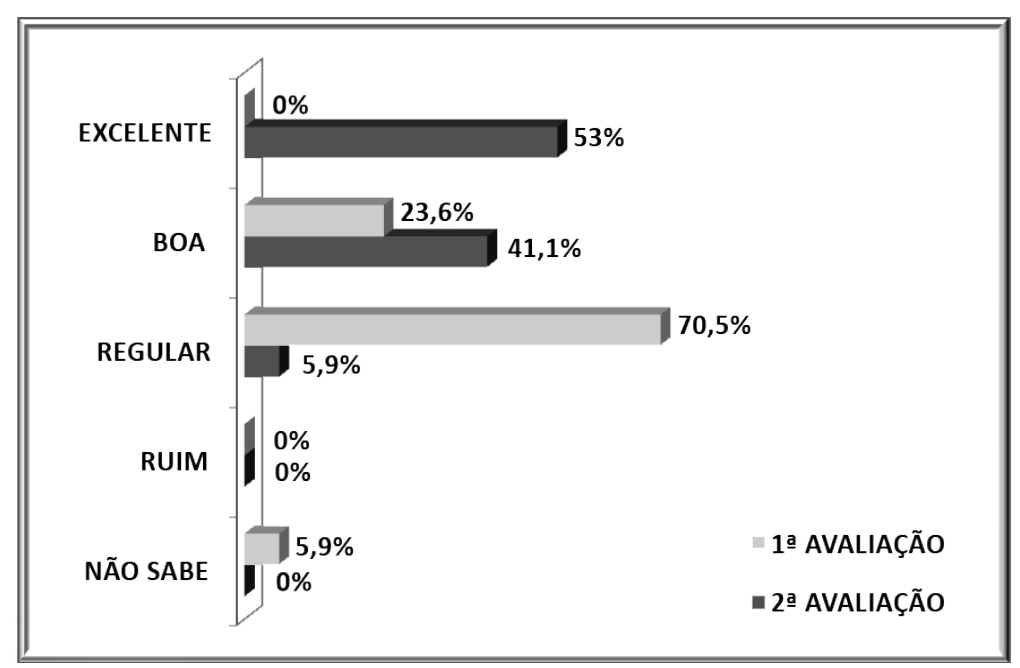

Fonte: Sobral. Secretaria Municipal de Saúde, 2014. 
De acordo com a figura 3, identifica-se que houve uma melhora evidente com relação a todas as variáveis citadas acima. $\mathrm{Na} 1$ a avaliação obteve-se $23,6 \%$ das mulheres considerando sua saúde como boa, 70,5\% como regular, $5,9 \%$ não souberam responder e nenhuma avaliou-a como excelente. Com a realização da $2^{a}$ avaliação, é possível perceber que esse cenário transformou-se, uma vez que obteve-se $53 \%$ das mulheres considerando sua saúde como excelente, $41,1 \%$ como boa e apenas 5,9\% como regular.

As participantes passaram a ver o grupo como um espaço promotor de saúde, uma vez que puderam perceber, por intermédio da Avaliação Corporal Integrada/ Monitoramento, as melhorias de saúde ocorridas durante o período de participação nas práticas corporais.

De acordo com Dias (2007), as práticas corporais são uma forma de "tratamento" para os problemas de saúde da população, promovendo uma recuperação mais acelerada ou o controle da enfermidade de forma segura, eficaz e com menos despesas. Fraga et al. (2009) ressaltam outra ideia, a de que deve-se ter cuidado em relacionar as práticas corporais como um "medicamento", com a ideia de que funciona como uma espécie de "panaceia", um remédio para todos os males. Com vistas ao comportamento, a Figura 4, trata do comparativo comportamental das mulheres do Grupo da Paz.
Figura 4-Comparativo comportamental das participantes do Grupo da Paz do território dos Terrenos Novos em Sobral (CE).

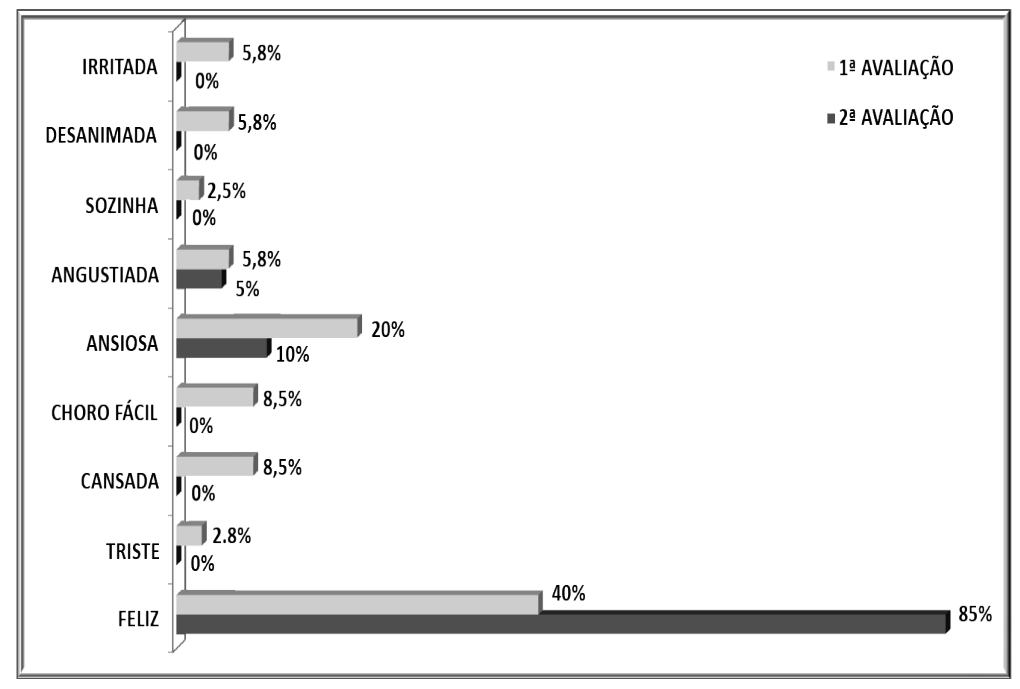

Fonte: Sobral. Secretaria Municipal de Saúde, 2014.

A partir da figura 4, percebe-se que houve uma melhora expressiva no quadro comportamental. A informação mais expressiva apresentada na 1a avaliação foi que $40 \%$ das participantes diziam-se felizes e na 2 a avaliação nota-se que esse índice elevou-se para $85 \%$, ou seja, alçou mais que o dobro do valor identificado na avaliação inicial.

Foi identificado também, que todas as outras variáveis foram minimizadas, comparando-se a 1a com a 2a avaliação das mulheres. Isso implica dizer que, de forma efetiva, as práticas corporais contribuíram para melhoria dessa condição comportamental.

As práticas corporais, quando realizadas de forma regular, proporcionam diversos benefícios, sendo de caráter tanto fisiológico quanto psicossocial. Tais benefícios 
psicossociais são: elevação da autoestima e do bemestar, alívio do estresse, estímulo ao convívio social. Ainda incluem-se nestes benefícios: a melhora da autoimagem, a diminuição da depressão, a manutenção da autonomia e redução do isolamento, bem como a melhoria da sensação de bom humor, redução da ansiedade e tensão. (SILVA; BARROS, 2010; BRASIL. MINISTÉRIO DA SAÚDE, 2006b; MATSUDO et al., 2002; COSTA et al., 2003)

Confirmaram-se estes efeitos significativos nas participantes do Grupo da Paz, haja vista, inclusive, a necessidade de ressaltar a dimensão do lazer proporcionada pelas práticas corporais, que veio contribuir bastante para a mudança deste quadro. A Figura 5 apresenta o grau de satisfação pela capacidade de desempenhar as atividades do dia a dia das participantes do Grupo da Paz.

Figura 5 - Grau de satisfação pela capacidade de desempenhar as atividades do dia a dia das participantes do Grupo da Paz do território dos Terrenos Novos em Sobral (CE).

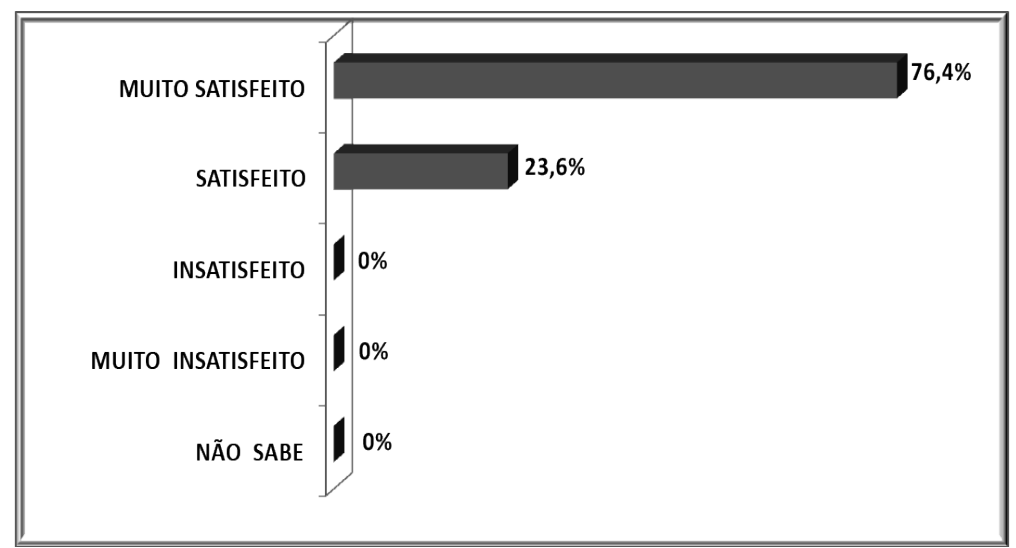

Fonte: Sobral. Secretaria Municipal de Saúde, 2014.
No tocante à figura 5 , identifica-se que $23,6 \%$ das mulheres estão satisfeitas com sua capacidade de desempenhar as atividades diárias e 76,4\% delas indicam estarem muito satisfeitas.

Observa-se que essas práticas contribuíram significativamente para melhorar o desempenho das atividades cotidianas das mulheres, diminuindo as dores articulares, desconfortos físicos e, consequentemente, melhoraram a qualidade de vida, a saúde e bem-estar das participantes.

Vale ressaltar que essa variável foi apurada apenas na 2. a avaliação, assim, não é possível comparar os dados com a Avaliação Corporal Integrada, realizada anteriormente.

A existência de atividades envolvendo práticas corporais, na comunidade, pode trazer resultados expressivos para os participantes em relação à melhoria da saúde. Portanto, promovê-las deve ser uma ação prioritária na Estratégia Saúde da Família. (BRASIL. MINISTÉRIO DA SAÚDE, 2006a)

Para Silva e Barros (2010), as práticas corporais são ações que propiciam a melhoria da saúde da população, a redução dos agravos e dos danos decorrentes das DANTs, e que favorecem a redução do consumo de medicamentos, a formação de redes de suporte social e que possibilitam a participação ativa dos usuários na elaboração de diferentes projetos terapêuticos. 


\section{Conclusão}

Identificou-se que existe uma relação intrínseca entre práticas corporais e a promoção da saúde no grupo de mulheres da Estratégia Saúde da Família, do território compreendido pela área do bairro Terrenos Novos, em Sobral (CE). Foram constatadas melhorias antropométricas e psicossociais significativas nas participantes do Grupo da Paz. Desta forma, enfatiza-se a importância das práticas corporais na efetivação de ações de promoção da saúde no território.

Os resultados da pesquisa estão em consonância com o que determina o objetivo geral da Política Nacional de Promoção da Saúde, que é promover a qualidade de vida e reduzir vulnerabilidade e riscos à saúde relacionados aos seus determinantes e condicionantes, prevendo, inclusive, o desenvolvimento de ações ligadas às áreas de prática corporal, promoção da saúde, dentre outras.

Desta forma, observou-se que as práticas corporais podem proporcionar uma melhoria da saúde individual e/ou coletiva, causando um grande impacto na saúde pública, pois intervêm diretamente nos fatores de risco das DANTs, prevenindo-as e diminuindo suas complicações, prolongando a vida com mais qualidade e contribuindo com a redução da prevalência dessas doenças.

Essas práticas necessitam de um olhar sistematizado e seguidas avaliações que ofereçam dados claros e demonstrem à população a importância e a necessidade de aderir às práticas corporais para a melhoria da saúde esperada.

Esse estudo fundamenta uma das possibilidades de atuação do profissional de Educação Física na ESF. A partir dessas avaliações, a equipe de referência, em parceria com a equipe de apoio multiprofissional, como o Núcleo de Apoio à Saúde da Família (NASF) e RMSF, irão intervir com atividades que visem um olhar mais ampliado para essas práticas.

Entende-se ainda, que se faz necessária uma maior quantidade desses profissionais no serviço público de saúde, para oferecer um maior suporte às atividades de práticas corporais e ampliá-las, buscando atender todos os bairros da cidade.

Além de proporcionar a detecção de fatores de risco à saúde, bem como um monitoramento, a avaliação deve fundamentar estratégias de promoção à saúde, possibilitando que os profissionais envolvidos no processo de cuidar possam mediar as ações de controle e prevenção por meio de práticas efetivas de promoção à saúde.

A sistematização e monitoramento dos grupos educativos, na atenção primária, são de grande relevância, pois evidenciam a importância de trabalhar com ações coletivas. O acompanhamento permitirá uma análise dos processos, bem como redirecionamentos das atividades voltadas para o perfil epidemiológico do grupo, e também garantirá o acesso das pessoas ao serviço de Avaliação Corporal Integrada.

Faz-se necessário um olhar mais crítico sobre o território, para entender seus determinantes e condicionantes de saúde, a fim de buscar novas alternativas que venham contribuir com a melhoria da qualidade de vida da população. Destaca-se também, a contribuição para o aprofundamento do tema tão presente no cotidiano do professor de Educação Física na ESF. 


\section{Referências}

BOMFIM, A.H. et al. Territorialização e inserção nos serviços de Saúde da Família: Conhecendo a realidade de Terrenos Novos e Vila União. Sobral: UVA/EFSFVS, 2008.

BRASIL. Ministério da Saúde. Saúde da Família: uma estratégia para a reorientação do modelo assistencial. Brasília: Ministério da Saúde, 1988.

Projeto promoção da saúde. As cartas da promoção da saúde. Secretaria de Políticas de Saúde. Brasília, Governo Federal: Ministério da Saúde, 2002.

Política Nacional de Promoção da Saúde. Brasília: Ministério da Saúde, 2006a.

- Obesidade. Cadernos de atenção básica, Brasília, n. 12, 2006b.

. Protocolos do Sistema de Vigilância Alimentar e Nutricional - SISVAN na assistência à saúde. Secretaria de Atenção à Saúde. Brasília: Ministério da Saúde, 2008.

COSTA, I.T. A importância da atividade física para a manutenção da saúde e os principais fatores que motivam professores, alunos e funcionários de duas universidades brasileiras a praticarem exercícios. Revista Brasileira de Atividade Física e Saúde, Florianópolis, v. 8, n. 1, p. 52-61, 2003.

DIAS, J.A.A importância da execução de atividade física orientada: uma alternativa para o controle de doença crônica na atenção primária. Revista Digital, Buenos Aires, ano 12, n. 114, 2007. Disponível em: <http://www. efdeportes.com/efd114/a-importancia-da-execucao-deatividade-fisica-orientada.htm>. Acesso em: 11 fev 2014.
FRAGA, A.B. Concepções de gênero nas práticas corporais de adolescentes. In: Movimento, Porto Alegre, v.2, n.3, 1995.

FRAGA, A.B. et al. "Eu acho que sedentarismo é...": concepções de praticantes de caminhada e medicalização das práticas corporais. In: XVI Conbrace e III Conice, 2009, Salvador. Anais..., Salvador: CBDE, 2009.

FREITAS, F.F. de et al. Práticas corporais e saúde: Novos olhares. In: Revista Brasileira de Ciências do Esporte, Campinas, v. 27, n. 3, p. 169-183, 2006.

GUIMARÃES, A.C.A.; BAPTISTA, F.M. Índice de massa corporal e qualidade de vida relacionada com a saúde de mulheres de meia-idade. In: Revista Brasileira de Clínica Médica, Santa Catarina, v.6, n.6, p.228-232, 2008.

IBGE - INSTITUTO BRASILEIRO DE GEOGRAFIA E ESTATÍSTICA. Censo 2010. Rio de Janeiro, 2010. Disponível em: <http:// www.ibge.gov.br>. Acesso em: 13 fev 2014.

LAZZAROTTI FILHO, A. et al. O termo práticas corporais na literatura científica brasileira e sua repercussão no campo da Educação Física. In: Movimento, Porto Alegre, v.16, n.1, p.11-29, 2010.

MATSUDO, V.K.R. et al. Nível de atividade física da população do Estado de São Paulo: análise de acordo com o gênero, idade, nível sócio-econômico, distribuição geográfica e de conhecimento. In: Revista Brasileira de Ciência e Movimento, Rio de Janeiro, v.10, p.41-50, 2002.

MERHY, E.E. Em busca do tempo perdido: micropolítica do trabalho vivo em saúde. In: MERHY, E.E; ONOCKO, R. (Orgs). Agir em saúde: um desafio para o público. São Paulo: Hucitec, 2005. p. 71-111. 
Saúde: A cartografia do trabalho vivo. 2. ed. São Paulo: Hucitec, 2002.

MORETTI, A.C. et al. Práticas corporais/atividade física e políticas públicas de promoção da saúde. In: Saúde \& Sociedade, São Paulo, v. 18, n. 2, p. 346-354, 2009.

PINTO, B.K. et al. Promoção da saúde e intersetorialidade: um processo em construção. In: Revista Mineira de Enfermagem, Belo Horizonte, v.16, n.4, p.487- 493, 2012.

SANTOS, L.A.S. O corpo, o comer e a comida: um estudo sobre as práticas corporais e alimentares no mundo contemporâneo. Salvador: Edufba, 2008.

SANTOS, V.C. et al. Atividade Física Supervisionada Junto à Comunidade do Vale do Redentor II: uma parceria entre a Faculdade Euclides Cunha (FEUC) e o programa de saúde da família de São José do Rio Pardo. In: Revista Logos, São José do Rio Pardo, n. 14, 2006.

SOBRAL. SECRETARIA MUNICIPAL DE SAÚDE. SIMACI Sistema de informação e monitoramento da avaliação corporal integrada. Sobral, 2010.

SIMACI - Sistema de informação e monitoramento da avaliação corporal integrada. Sobral, 2014.

SIAB - Sistema de Informação da Atenção Básica. Disponível em: <http://www2.datasus.gov.br/SIAB/index. php?area=04>. Acesso em: 15 fev 2014.

SILVA, A.F.A.C.; BARROS, C.L.M. O profissional de Educação Física e a promoção da saúde: enfoque dos programas de saúde da família. In: Revista Digital, Buenos Aires, ano 15, n.145, 2010. Disponível em: <http://www.efdeportes. com/o profissional de Educação Física e a promoção da saúde.htm>. Acesso em: 10 fev 2014.
SILVA, A.L.F. et al. Educação Física na atenção primária à saúde em Sobral - Ceará: Desenhando saberes e fazeres integralizados. In: SANARE - Revista de Políticas Públicas, Sobral, v.9, n.2, p.63-72, jun./dez. 2009.

SOUSA FILHO, F.S.F.; RODRIGUES, A.B. Perfil antropométrico das mulheres participantes do grupo de ginástica comunitária do território cidade Dr. José Euclides (Terrenos novos) em Sobral - Ce. Rio de Janeiro: UVA, 2012.

STARFIELD, B. Atenção primária: equilíbrio entre necessidades de saúde, serviços e tecnologias. Brasília: UNESCO/Ministério da Saúde, 2002.

TEIXEIRA, S.M.F. Reforma sanitária brasileira: dilemas entre o instituinte e o instituído. In: Ciência \& Saúde Coletiva, Rio de Janeiro, v.14, n.3, p.743-752, 2009.

THOMAS, J.R. et al. Métodos de pesquisa em atividade física. 6ed. Porto Alegre: Artmed, 2001.

OMS - Organização Mundial de Saúde. Obesidade: prevenção e gestão de epidemia global. Relatório da Consulta da OMS. Relatório Técnico da OMS Série 894. Genebra: Organização Mundial da Saúde, 2000.

ZAMAI, C.A.; BANKOFF, A.D.P. Nível de atividade física e indicadores de qualidade de vida de colaboradores da Unicamp: Análise através do Programa Mexa-se Unicamp. In: XI Simpósio Nordestino de Atividade Física \& Saúde: da evidência a intervenção, 2010, Aracaju. Anais. Aracaju: UFS, 2010. 


\section{INSPIRE, EXPIRE E NÃO PIRE: GINÁSTICA LABORAL COMO PROMOTORA DE SAÚDE DOS TRABALHADORES DO SUS}

Odemir Pires Cardoso Júnior Maria Lidiany Tributino de Sousa

\section{Introdução}

O trabalho, ao longo dos séculos, e as atividades laborais propostas aos homens e mulheres como condição de vida, passou por várias transformações nas organizações. É pelo trabalho que os homens e mulheres realizam-se, transformam-se, aperfeiçoando constantemente suas formas de agir. É a partir dessa transformação que o ser humano desenvolve um processo de aprendizagem dos seus limites e de suas potencialidades.

Desde a Revolução Industrial, a sociedade vive em um mundo de tecnologia e equipamentos avançados, exigindo do trabalhador uma forma de produção automatizada e repetitiva. As competências humanas não se orientam como a âncora do emprego, porém, exige-se do trabalhador a capacidade de adaptação extrema àquilo que o mercado de trabalho oferece-Ihe como alternativa de sobrevivência, 
submetendo-o à execução de qualquer atividade que Ihe garanta o cumprimento mínimo necessário à sua sobrevivência. (MAZZARINO, 2011)

O problema do capitalismo é que, aqui como em qualquer parte, ele destrói as possibilidades humanas por ele criadas. Estimula, ou melhor, força o autodesenvolvimento de todos, mas as pessoas só podem desenvolver-se de maneira restrita e distorcida. As disponibilidades, impulsos e talentos que o mercado pode aproveitar são pressionados (quase sempre prematuramente) na direção do desenvolvimento e sugados até a exaustão; tudo o mais, em nós, tudo o mais que não é atraente para o mercado é reprimido de maneira drástica, ou se deteriora por falta de uso, ou nunca tem uma chance real de se manifestar. (BERMAN, 2007)

Segundo Spilkf et al. (2009), todo o trabalho na contemporaneidade é marcado por uma revolução técnicoindustrial, logo, o aumento da produtividade, a redução dos custos e a introdução de novas tecnologias, impõem aos trabalhadores alterações significativas na sua forma de trabalhar.

Durante toda a fase produtiva, o corpo sofre alterações decorrentes dos esforços aos quais é submetido, portanto, o ritmo excessivo de trabalho, a postura inadequada, os movimentos repetitivos, os esforços e situações de trabalho, causadores de estresse e fadiga, assim como as condições físicas inadequadas dos postos de trabalho, causam tensões no corpo. As tensões ainda podem ocasionar falta de atenção laboral e acidentes de trabalho. (SANTOS et al., 2007)

Essas alterações impuseram novos modos de adoecimento dos trabalhadores e/ou novos modos de manifestação de patologias associadas ao trabalho como as Lesões por Esforços Repetitivos (LER) e os Distúrbios
Osteomusculares Relacionados ao Trabalho (DORT). É pertinente enfatizar que elas respondem por 80 a $90 \%$ dos casos de doenças profissionais registrados nos últimos anos pela Previdência Social. (BRASIL. MINISTÉRIO DA SAÚDE. SECRETARIA DE VIGILÂNCIA EM SAÚDE. DEPARTAMENTO DE VIGILÂNCIA EM SAÚDE AMBIENTAL E SAÚDE DO TRABALHADOR, 2012a)

LER/DORT é descrita pelo Instituto Nacional de Seguro Social (INSS) como uma síndrome clínica, caracterizada por dor crônica, com ou sem degeneração de tecidos, que se manifesta principalmente no pescoço, na região escapular e/ou nos membros superiores em decorrência do trabalho, sendo frequentemente causa de incapacidade laboral temporária ou permanente. Assim, são espécies de LER/ DORT, as neuropatias compressivas, como a "síndrome do desfiladeiro torácico" e a "síndrome do túnel do carpo", as tendinites, epicondilites e tenossinovites, as fibromialgias e assemelhadas. (BRASIL. MINISTÉRIO DA PREVIDÊNCIA SOCIAL, 2003)

Cabe ressaltar que acidentes e doenças relacionados ao trabalho são agravos previsíveis e, portanto, evitáveis. Parece-nos que, no Brasil, no processo de consolidar-se enquanto campo, a saúde do trabalhador ganha um lugar: o Sistema Único de Saúde (SUS). Fica então assegurado no campo de atuação do SUS, um conjunto de ações de vigilância e assistência, visando a promoção, a proteção, a recuperação e a reabilitação da saúde dos trabalhadores submetidos a riscos e agravos advindos dos processos de trabalho. (BRASIL. PRESIDÊNCIA DA REPÚBLICA, 1990)

É importante salientar que, atualmente, as ações em Saúde do Trabalhador, no âmbito do SUS, têm se desenvolvido de forma isolada e fragmentada das demais ações de saúde. O registro das informações sobre a real situação de saúde dos trabalhadores, a falta de planejamento 
e implementação de ações práticas, bem como a escassez e inconsistência de instrumentos importantes para a melhoria da vida e trabalho, dificultam a definição de prioridades na construção de políticas públicas efetivas.

$\mathrm{O}$ atual sistema de segurança e saúde do trabalhador carece de mecanismos que incentivem medidas de promoção, responsabilizem os empregadores, propiciem o efetivo reconhecimento dos direitos do segurado, diminuam a existência de conflitos institucionais, tarifem de maneira mais adequada as empresas e possibilitem um melhor gerenciamento dos fatores de riscos ocupacionais. (BRASIL. MINISTÉRIO DA SAÚDE. SECRETARIA DE ATENÇÃO À SAÚDE. DEPARTAMENTO DE AÇÕES PROGRAMÁTICAS ESTRATÉGICAS, 2004)

No sentido de garantir o acesso a uma atenção qualificada, com a finalidade da promoção da melhoria da qualidade de vida dos trabalhadores brasileiros, o Ministério da Saúde instituiu, em 2012, a Política Nacional de Saúde do Trabalhador e da Trabalhadora (PNSTT) e exige que sua atuação seja executada de forma multiprofissional, interdisciplinar e intersetorial.

Abordar as questões de Saúde do Trabalhador nessa perspectiva inovadora significa ampliar o olhar para além do processo laboral, considerando os reflexos do trabalho e das condições de vida dos indivíduos e das famílias, envolvendo uma abordagem integral do sujeito, a responsabilização, o acolhimento e a integralidade. (O`NEILL, 2003)

Segundo a referida política (BRASIL. MINISTÉRIO DA SAÚDE, 2012b), a categoria trabalho deve ser incorporada como determinante do processo saúde-doença dos indivíduos e da comunidade, uma vez que mudanças identificadas nas situações e nas atividades de trabalho realizadas expressam, entre outros, o crescente aumento da prevalência de doenças relacionadas ao trabalho, acarretando a diminuição da qualidade de vida do trabalhador.

A qualidade de vida resulta do tratamento humano, da gentileza, da leveza nas relações, da possibilidade de expressão de pontos de vista divergentes, do relacionamento sincero, do respeito aos ausentes e do orgulho pelo que se faz. Atenção, elogio e consideração constituem ingredientes indispensáveis quando se busca lealdade, qualidade e produtividade. (SUCESSO, 2002)

A PNSTT registra que a Atenção Primária à Saúde (APS), e mais especificamente a Estratégia Saúde da Família (ESF), deve ser o espaço de acesso à atenção qualificada para estabelecer o nexo causal entre o quadro de morbimortalidade verificado no âmbito dos processos de trabalho de um determinado território. A APS balizada pela integralidade, territorialidade e continuidade com cuidado é o espaço de possíveis ações sobre os determinantes dos agravos decorrentes dos modelos de desenvolvimento e processos produtivos.

Sobral, cidade situada na região norte do estado do Ceará, tida como referência na Atenção Primária à Saúde, tem sua Rede de Atenção à Saúde do Trabalhador composta por um Centro de Referência em Saúde do Trabalhador (CEREST) e pelas unidades sentinelas (Centro de Reabilitação, Santa Casa, Policlínica, dentre outros). Estes espaços de referência identificam, investigam e notificam casos de doenças, agravos e/ou acidentes relacionados ao trabalho.

Na APS de Sobral, o cuidado aos trabalhadores é realizado impreterivelmente na proposta de educação permanente e, neste sentido, os recursos tecnológicos com que conta são praticamente inesgotáveis, entretanto, as ações promocionais ainda são muito pontuais, insuficientes. Estima-se potencializar mais espaços que fortaleçam 
o trabalho vivo enquanto tecnologia leve, que produz um compromisso permanente com a tarefa de acolher, responsabilizar, resolver e automatizar a saúde.

O processo de produção do cuidado não pode ser globalmente capturado pela lógica do trabalho morto, expresso nos equipamentos e nos saberes tecnológicos estruturados (tecnologias leve-duras e duras), pois o seu objeto não é plenamente estruturado. Estima-se a reforma no modo de se produzir saúde, contemplando mais tecnologias, basicamente leves, pautadas numa relação interpessoal intensa, de encontro de subjetividades (produção de vínculo, autonomização, acolhimento), ressaltando um trabalho vivo em ato, para além da dimensão meramente tecnológica. (MERHY, 1997)

Desse modo, surgiu em 2012, através de um grupo de ginástica laboral, com enfoque ampliado de saúde, um programa de melhoria da qualidade de vida no trabalho, praticado no Centro de Saúde da Família (CSF) de forma voluntária e coletiva pelos funcionários na hora do expediente.

Diante desse cenário de indicadores, rede de cuidados, motivações pessoais, esse trabalho tornou-se relevante pela iniciativa de proporcionar ferramentas indispensáveis e diferenciadas, ampliando o escopo de ações de Saúde do Trabalhador, tendo como objetivo, analisar o potencial dos grupos de ginástica laboral na promoção da saúde dos trabalhadores da APS de Sobral, refletindo a partir de algumas problematizações: De quem é a responsabilidade, na APS, pelo cuidado da saúde do trabalhador? Quem os profissionais da APS reconhecem como cuidadores?

\section{Metodologia}

Trata-se de uma pesquisa descritiva e exploratória, com abordagem qualitativa, no intento de responder às problematizações surgidas e aos objetivos formulados. Realizou-se em dois Centros de Saúde da Família (CSF), nos quais aconteciam os grupos de Ginástica Laboral, ambos no município de Sobral no Estado do Ceará.

Os critérios para seleção dos participantes no estudo foram: serem funcionários dos CSF elencados e participantes dos grupos de ginástica laboral, de ambos os sexos, assíduos há mais de três meses, que concordaram com o Termo de Consentimento Livre e Esclarecido. Vale ressaltar que se utilizou como critério de seleção a diversidade, tendo sido escolhidos profissionais que contemplassem as diversas categorias e a saturação das informações para fechamento do tamanho final da amostra de informante. (FONTANELLA; RICAS; TURATO, 2008)

A amostra inicial foi composta por 24 participantes, no entanto, 5 deles no momento da convocação não aceitaram participar, sendo assim a amostra relevante conteve 18 participantes, dentre eles, 12 do CSF Sinhá Sabóia, pela larga disponibilidade de participantes, e somente 6 do CSF Terrenos Novos, pela limitação de amostra: 5 Agentes Comunitários de Saúde, 1 enfermeiro, 3 auxiliares de serviços gerais, 3 auxiliares de enfermagem, 3 auxiliares administrativos e 3 auxiliares de farmácia.

O grupo surgiu da observação da rotina do CSF, na tentativa de assegurar o cuidado e efetivar práticas de saúde aos trabalhadores, bem como da criticidade ao termo ginástica, com enfoque puramente corriqueiro, tedioso e reprodutivo. A pesquisa foi então, desenvolvida em dois momentos. 
No primeiro momento foram realizadas várias atividades integrativas, tais como: alongamento, relaxamento, soltura, massagem, dinâmicas de grupo, utilizando-se algumas vezes materiais como bastões, colchonetes e bolas. Além dessas atividades, foi aplicada uma série de exercícios básicos e outros mais específicos, de acordo com a função desenvolvida, com a intenção de reduzir dores, fortalecer a musculatura e reeducar posturas. Para tanto, houve um planejamento adequado, com pausa no trabalho sem que houvesse prejuízo no serviço, funcionando como uma ruptura da monotonia. A atividade foi realizada dentro da jornada de trabalho, com sessões de 10 ou 15 minutos e a adesão foi voluntária.

No segundo momento, foram realizadas entrevistas semidirigidas, concretizando a coleta de dados, que foi realizada em fevereiro de 2014 , de segunda a sexta, no horário do expediente. Por meio dessa técnica, dados foram coletados combinando perguntas fechadas e abertas, versando sobre: motivos para participação do grupo, surgimento e funcionamento do grupo, potencialidades e desafios dos grupos laborais, condições de trabalho, mudanças sentidas e responsabilidade da APS no cuidado da saúde do trabalhador, situação que possibilitou um espaço para os entrevistados, no sentido de ficarem livres para discorrer sobre o tema proposto.

Para atingir os resultados, foi utilizado o método denominado "Análise de Conteúdo". Esse método propõe encontrar respostas para os questionamentos formulados, além disso, diz respeito à descoberta dos elementos inerentes ao conteúdo manifesto. (BARDIN, 1977) Foi realizada, portanto, uma leitura flutuante e a pré-análise do material.

A inserção do pesquisador nesse grupo foi desde a sua criação, como cuidador, que além de pensar na organicidade desse conjunto, procurava acrescentar aos momentos reflexões sobre relações interpessoais e aspectos motivacionais no ambiente de trabalho, simbolizando um trabalho vivo em ato, operacionalizado por tecnologias leves.

\section{Análise e discussão}

Rotina de trabalho x Qualidade de vida: "Cuidar de mim é mais difícil, quando vou cuidar de mim é tarde."

A intensificação laboral é traço característico da modernidade e tem levado ao consumo desmedido das energias físicas e espirituais dos trabalhadores, uma vez que exige cada vez mais, o limite máximo funcional e ignora o tempo de repouso necessário para restaurar a relação entre mente, corpo e ambiente. (ELIAS, 2006)

Muito cansada, muito tensa, às vezes estressada. Na verdade, quando eu chego em casa só penso mesmo numa boa cama e dormir. Não tenho vontade de mais fazer nada. (Enfermeira 2)

Cuidar de mim é mais difícil, quando vou cuidar de mim é tarde. (Auxiliar de serviços gerais)

O corpo humano adapta-se ao ambiente à procura de uma posição mais confortável e funcional, logo, a postura ideal é a posição do corpo que envolve o mínimo de estiramento e de tensão das estruturas osteomusculares, gastando menos energia e obtendo-se o máximo de eficiência no uso do corpo, no entanto, muitas vezes, a pessoa assume posturas inadequadas, devido à falta de consciência postural e principalmente, as intensas, 
desgastantes e massacrantes jornadas de trabalho, o que se comprova no relato da maioria dos trabalhadores da Atenção Primária de Sobral.

Atuo na sala de vacinas... me desloco bastante, fico muito tempo em pé e mudo muito de posição... no fim do dia estou esgotada fisicamente (Técnica de enfermagem). Sinto-me acabada. É um rojão muito grande, aqui no Posto tem muita gente, não dá nem pra sentar (Atendente de Farmácia).

A maioria das reações adversas, induzidas pelo trabalho, tais como: ansiedade, estresse e depressão ocorrem quando a demanda do trabalho é alta e o grau de controle do trabalhador sobre o trabalho é baixa, portanto, o aumento da responsabilidade, decorrente do aumento da autonomia, provoca na prática, mais carga de trabalho e maior tensão entre os trabalhadores, afetando negativamente a saúde. (ARAÚJO et al., 2003)

Sou enfermeira e o pior é o acolhimento, que é desumano. Atendo 40 a 50 pacientes por turno. Não posso deixar de atender. (Enfermeira 1). Sou polivalente, a gente faz uma coisa aqui, uma coisa acolá. É muita tarefa pra executar. A rotina é de muita responsabilidade (Técnica de enfermagem).

Para a ergonomia, as condições de trabalho são representadas por um conjunto de fatores interdependentes que atuam direta ou indiretamente na qualidade de vida das pessoas e nos resultados do próprio trabalho. Neste sentido, torna-se indispensável à vigilância dos riscos advindos das condições e dos ambientes e processos de trabalho a abordagem ergonômica, cujo objeto é o trabalhar e as regulações decorrentes desta prática. A má adaptação do mobiliário, a falta de manutenção em equipamentos e ferramentas e a ausência de recursos materiais e humanos para execução do número de atividades que realizam são algumas das queixas elencadas pelos profissionais no ambiente produtivo. (ABRANCHES, 2005)

Passo muito tempo sentada. As cadeiras, normalmente, não são confortáveis (Auxiliar administrativo).

O trabalho ocupa um espaço muito importante na vida de todo indivíduo, sendo que muitas vezes passa-se mais horas dentro do âmbito ocupacional do que em casa, o que resulta na necessidade da criação de propostas diferenciadas para melhoria e incentivo da qualidade de vida do trabalhador ativo. (SOUZA, 2010)

É de 7:00 às 12:00 como agente de saúde, ai tiro uma hora de almoço, ai 13:00 a 13:30 to voltando, continuo como agente de saúde, quando dá 16:00 já entro aqui como auxiliar até às 20:00, são três expediente que eu dô (Agente de Saúde).

O trabalho afeta todas as dimensões da vida humana: física, afetiva, intelectual e espiritual. As relações de solidariedade e cooperação no cotidiano de trabalho, essenciais para a saúde e segurança dos trabalhadores, são atualmente substituídas pela competitividade e produtividade, contribuindo para a falta de qualidade de vida no trabalho, o que produz naturalmente, impactos importantes nos resultados das organizações, como: índices de absenteísmo, rotatividade e custos altos de assistência médica.

Segundo Pereira (2006), a qualidade de vida no trabalho resulta do equilíbrio dinâmico que envolve os 
aspectos físico, psíquico e social, onde são respeitadas as necessidades e limitações do ser humano, resultando num crescimento pessoal e profissional. Batista (2010) complementa que a qualidade de vida pode ser definida como momentos de lazer e descanso aliados à prática de exercícios laborais dentro das organizações, logo, é de se destacar que o centro da qualidade de vida dentro do sistema de trabalho deve ser o indivíduo.

\section{Entre Desafios e Potencialidades: e assim caminha o grupo}

O ritmo de trabalho, com o advento da modernidade, passou a ser ditado pelo relógio, porém, é necessário ressaltar que a mão de obra nesse sistema foi afetada, portanto, é preciso que os gestores proporcionem condições necessárias aos funcionários, mas principalmente a qualidade de vida dos mesmos. Assim, as entrevistas apontam que a ginástica laboral foi incluída após sugestão dos trabalhadores à gestão como uma forma de cuidado à saúde.

Já fazia fisioterapia e continuava sentindo muitas dores... foi mais uma oportunidade de melhorar... (Técnica de enfermagem)

Nós profissionais estávamos precisando melhorar o nosso dia de trabalho. (Agente de Saúde)

A Ginástica Laboral pode atuar positivamente na saúde do trabalhador, uma vez que consiste basicamente na realização de exercícios específicos de alongamento e de fortalecimento muscular, tentando impedir que se instalem vícios posturais durante as atividades habituais. É praticada no ambiente produtivo, direcionada para a musculatura mais requisitada durante a jornada de trabalho, com sessões de 10 ou 15 minutos. Destaca-se pela fácil implantação, baixo custo, pouco tempo necessário a sua realização e pelos rápidos resultados obtidos. A pesquisa mostra que a inovação exercida nessa nova modalidade, adicionando exercícios de coordenação motora e relaxamento, além da redução do estresse psicológico, forma vínculos e estimula a participação no grupo. (MARTINS, 2005)

Fazíamos alongamento, a gente dançava, tinha uma parte de dança, né, que alongava o corpo todo, depois tinha relaxamento, a gente deitava, ele colocava uma música e a gente relaxava. (Auxiliar administrativo)

Evidenciam-se mudanças positivas após a entrada dos trabalhadores no grupo de ginástica laboral, tendo sido relatada uma melhora da condição física geral, aumento do ânimo e disposição para o trabalho, controle do estresse, bem como diminuição de acidentes de trabalho. Neste sentido, a implantação de um programa diferencial de Ginástica Laboral busca despertar nos trabalhadores a necessidade de mudanças no estilo de vida, e não alterações apenas nos momentos de ginástica.

Quando estava fazendo, me sentia super bem, relaxada. Parece que descarregava mais aquela adrenalina de estrese e ansiedade. Parece que ficava tudo ali. (Agente de Saúde)

Me sinto bem, quando eu chego em casa eu sou mulher pra limpar, pra varrer, pra tudo. (Auxiliar administrativo)

Porque só trabalhar e não fazer uma atividade física, eu acho que fico assim, ansiosa, travada. (Atendente de farmácia)

A postura adotada pelos funcionários no seu dia de trabalho, nos centros de saúde pesquisados, caracteriza-se por ser pobre em termos de qualidade, destacando-se os 
movimentos realizados de forma repetitiva e a permanência de uma má postura, tornando os funcionários propensos a apresentar desconfortos ou problemas posturais. A atividade física diária, exemplificada na renovada ginástica laboral, além de promover a consciência corporal, contribui para a lubrificação das articulações, uma vez que alongar os músculos libera as tensões, aumenta a flexibilidade, melhora a circulação sanguínea, desintoxica as células, diminuindo assim, a incidência de dores musculares e vícios posturais. (BLOEMER, 2002)

Eu tava com uma dormência, dor nas costas, nas articulações. Tava com falta de sono, aí o professor me deu muita força pra ir e eu fui. Tudo mudou! (Auxiliar de serviços gerais)

As aulas decorrem em um ambiente descontraído, em que cada exercício e cada movimento são encarados com alegria e entusiasmo, estimulando assim, a descontração, a integração, o autoconhecimento e a autoestima, proporcionando uma possível melhora no relacionamento interpessoal e do indivíduo com o meio que o cerca. 0 aumento dos ciclos de amizade fortalece a autoestima e promove uma maior socialização. Esse olhar mais atento com o outro, reflexo do vínculo e da intimidade, seja na atenção dirigida (respeito), seja no cuidado com as atividades, continua a ser uma experiência curadora de grande força. (BERGAMASCHI, 2002)

O professor é uma pessoa muito popular e deixa a gente muito a vontade. A gente 'tando perto dele não tem tristeza, não! (Agente de Saúde).

O pouquinho que eu participava já dava aquela levantada no astral. (Atendente de Farmácia)
Dentre os desafios, estão: a vergonha, a falta de tempo, dificuldade para se ausentar do setor, interesse, além de destacarem que o local/espaço não é adequado para a atividade.

Porque assim, como é num espaço de horário de trabalho, a gente não tem um espaço adequado nem uma hora pra fazer isso. (Auxiliar administrativo)

Eu me sentia com vergonha. (Auxiliar de serviços gerais)

Na hora do grupo eu fico na sala de aerosol aí, às vezes, ficava as pessoas chamando e eu tinha que ficar saindo pra atender. (Técnica de enfermagem)

As principais barreiras enfrentadas pelos programas de qualidade de vida no trabalho são a sua concepção assistencialista e a ênfase na produtividade. As práticas de cuidado tem foco puramente assistencial, atuando como medidas compensatórias dos desgastes provocados pela tarefa de trabalho e não solucionando os problemas efetivos, os quais comprometem a saúde, o conforto e a segurança. No que se refere à produtividade, a crítica consiste no fato de que os programas preconizam o bemestar de modo secundário, tendo como meta maior o aumento da produtividade. O grande desafio está em construir os alicerces no trabalho com caráter promocional, portanto, são necessárias atuações interdependentes: nas condições de trabalho, na estrutura organizacional e nas relações sociais. (DIAS, 2009)

Uma vez pautada no conceito ampliado de saúde, a ginástica laboral aperfeiçoada deve ser tecnologia leve dependente, bem como torna-se uma das estratégias de promoção da saúde, uma vez que suas potencialidades implicam e confirmam o compromisso com a qualidade de 
vida dos trabalhadores do SUS, estimulando e fortalecendo o protagonismo dos sujeitos no cuidado à saúde.

\section{"E quem cuidará de nós?": A saúde do trabalhador e a Atenção Primária em Saúde}

A VIII Conferência Nacional de Saúde contribuiu para reafirmar à sociedade brasileira a saúde como direito de cidadania e dever do Estado. O Pacto de Gestão define as responsabilidades do Município, do Estado e da União com a saúde da população brasileira, elencando a Atenção Primária como prioridade do município, no sentido de executá-la e assegurá-la. Entretanto, o SUS ainda não incorporou, de forma efetiva, em suas concepções, paradigmas e ações, o lugar que o "trabalho", evidenciado na saúde do trabalhador, ocupa na vida dos indivíduos e suas relações com o espaço socioambiental. As entrevistas evidenciam as precárias condições de trabalho, a sobrecarga e as responsabilidades pela saúde dos trabalhadores do SUS.

A gente não tem tempo pra gente, tempo pra frequentar uma academia, fazer algo que possa melhorar a nossa saúde, o nosso bem-estar. (Agente de Saúde)

Uma pessoa só faz duas, três coisas. A gente se esforça muito. (Técnico de enfermagem)

A responsabilidade é de cada um de nós! Eu acho que cada um de nós temos que fazer a nossa parte, de cuidar da nossa saúde como cuidar da saúde do outro e é tipo uma troca. (Agente de Saúde)

A saúde define-se como um processo dinâmico, expresso no corpo, na pessoa, no trabalho, nas condições de vida, nas dores e no prazer, enfim, em tudo o que acompanha uma história, individual em sua singularidade, mas coletiva pela influência das múltiplas lógicas inscritas nesse processo, portanto, a saúde do trabalhador não pode ser medida somente por seu grau de adoecimento e afastamento do trabalho. Assim, vêm ganhando espaço os programas de pausas com exercícios, e cada vez mais cresce o envolvimento de profissionais das áreas de fisioterapia e educação física, visto o potencial relevante dessas áreas em termos de promoção de saúde. Entretanto, essa prática é mais comum no setor privado, não existindo evidências no setor público. (RIGOTTO, 2003)

Sobral, com sua trajetória relevante em saúde da família, por valorizar e acreditar na consolidação da ESF, incorpora novos profissionais a suas equipes, através do Núcleo de Apoio à Saúde da Família (NASF) e da Residência Multiprofissional em Saúde da Família (RMSF), assumindo o compromisso de proporcionar a integralidade do cuidado em saúde. A RMSF surge com a iniciativa de expandir as práticas promocionais, dirigindo o olhar preferencialmente ao coletivo, tendo como principal campo de ação a promoção à saúde.

Entretanto, fica constatado na pesquisa, que a rotatividade desses profissionais, prática comum, dificulta a continuidade do cuidado com os trabalhadores e após o levantamento de dados, observa-se que os dois únicos grupos de ginástica laboral existentes no município são facilitados por residentes, reconhecendo-os como atuais cuidadores e multiplicadores da Saúde do Trabalhador.

[...] desde que haja oportunidades e profissionais no local pra dá continuidade. (Técnico de enfermagem)

Pagar um profissional pra cuidar da gente, porque só a gente pra tratar da população, e quem cuida de nós? Existe um negócio, "cuidando do cuidador" que eu acho muito importante pra nós que temos uma carga 
horária pesada, como eu, por exemplo. (Atendente de farmácia).

Poderia trabalhar com regularidade a ginástica laboral em todas as unidades de saúde. (Enfermeira).

Imperativos históricos, de ordem técnica, normativa e legal, definem que o processo de construção da atenção integral à saúde dos trabalhadores no SUS, na atualidade, passa necessariamente, pela Atenção Primária. A ESF é a forma privilegiada de concretizar a atenção primária, trabalhando com o cuidado num território adscrito, entretanto, ironicamente, como fica a saúde do enorme contingente de trabalhadores que não moram nesse território? Como fica o processo de empoderamento do sujeito quando inexiste promoção da saúde do trabalhador para essas pessoas que talvez sejam as mais preparadas para assumir o comando desse processo? Corre-se o risco de considerar que a responsabilidade pela atenção a eles cabe ao "plano de saúde", que se ocupa prioritariamente, de medidas de atenção curativa, procurando recuperar parte da saúde perdida pelo trabalhador para permitir que ele volte ao trabalho. Quem se ocupa da promoção e da manutenção dessa saúde?

Acredita-se que o passo principal para o sucesso seja o gestor da atenção primária assumir, de fato e de direito, a responsabilidade pela saúde de todos que estão sob a sua jurisdição. Espera-se que ele deixe de ser apenas a figura de um gerente de unidade de saúde e trabalhe na perspectiva da corresponsabilização, utilizando da intersetorialidade para a integralidade nesse cuidado. Ressalta-se a importância da proposta de redes de atenção à saúde, onde a APS é considerada centro de comunicação dessa rede horizontal, responsável por resolver a maioria dos problemas de saúde.

\section{Considerações Finais}

O corpo é a principal ferramenta para o trabalho humano. São, portanto, inegáveis os ganhos quando se permite ao trabalhador tomar consciência do valor do seu corpo, respeitando seus limites e poupando-o de males plenamente evitáveis.

A Ginástica Laboral, atualmente aperfeiçoada, é um programa que têm gerado bastante resultados positivos, apesar do pouco tempo de implantação em algumas unidades de saúde de Sobral. Tais progressos estão relacionados à melhoria no desempenho pessoal no trabalho, melhora na postura durante a jornada de trabalho, bem como redução das queixas físicas.

Associando-se a Ginástica Laboral à saúde, em um contexto onde o ambiente de trabalho e o estilo de vida estão interligados, o que constatou-se nessa nova modalidade, observa-se a necessidade de abertura de espaços promotores de saúde no ambiente de trabalho, buscando mudanças mais humanizadas entre os trabalhadores, proporcionando assim modificações em seus hábitos cotidianos, bem como o desenvolvimento do empoderamento do sujeito, de sua corresponsabilidade no sentido de ter saúde.

Percebe-se que se é nas organizações que se passa a maior parte da vida, natural seria que as pessoas as transformassem em lugares mais agradáveis e saudáveis para a execução de seu trabalho, logo, estima-se que se invente um novo sistema produtivo, capaz de elevar a qualidade de vida no trabalho. Experiências como a aplicabilidade da Ginástica laboral, com enfoque ampliado de saúde, refletem indicadores positivos à satisfação e motivação do trabalhador, assim como na comunicação interpessoal, potencializando qualquer rotina de trabalho. 
Ressalta-se a importância da continuidade das ações, primando por um trabalhador mais ativo, satisfeito e íntegro, em sua totalidade.

\section{Referências}

ABRANCHES, S.S. A situação ergonômica do trabalho de enfermagem em unidade básica de saúde. Tese apresentada à escola de Enfermagem de Ribeirão Preto/USP - Programa de Pós-Graduação em Enfermagem Fundamental. Linha de Pesquisa: Saúde do Trabalhador. Ribeirão Preto, 2005.

BARDIN L. Análise de Conteúdo. Lisboa: Edições 70, 1977.

BATISTA, A.A.S. Análise da qualidade de vida no trabalho utilizando um modelo de regressão logística / Álamo Alexandre da Silva Batista. Dissertação (Mestrado em Engenharia de Produção) - Universidade Tecnológica Federal do Paraná, Campus Ponta Grossa. Curso de Pós-Graduação em Engenharia de Produção. Ponta Grossa, 2010.

BERGAMASCHI, E.C.; DEUTSCH, S.; FERREIRA, E.P. Ginastica Laboral: possíveis implicações para as esferas física, psicológica e social. In: Atividade Física e Saúde, São Paulo, v.7, n.3, 2002.

BERMAN, M. Tudo que é sólido desmancha no ar: a aventura da modernidade. São Paulo: Companhia das Letras, 2007.

BLOEMER, R. Postura e desconforto corporal em um ambiente de trabalho informatizado [Monografia]. Tubarão: Unisul, 2002.

BRASIL. Presidência da República. Lei n. 8.080, de 19 de setembro de 1990. Dispõe sobre as condições para a promoção, proteção e recuperação da saúde, a organização e o funcionamento dos serviços correspondentes, e dá outras providências. Diário Oficial da União (em itálico), Brasília, 20 de setembro de 1990.

BRASIL. Ministério da Previdência Social. Instrução Normativa INSS/Dc $\mathbf{N}^{\circ}$ 98, de 5 de dezembro de 2003 Anexo Seção I: Atualização Clínica das Lesões por Esforços Repetitivos (LER) Distúrbios Osteomusculares Relacionados ao Trabalho (DORT). Diário Oficial da União, Brasília, 2003. Disponível em: <http:www.mps.gov.br>. Acesso em: 04 abr 2013.

BRASIL. Ministério da Saúde. Secretaria de Atenção à Saúde. Departamento de Ações Programáticas Estratégicas. Área Técnica de Saúde do (a) Trabalhador (a)- COSAT. Política Nacional de Saúde do (a) Trabalhador (a)-Proposta para Consulta Pública - Documento em elaboração. Versão preliminar para discussão. Brasília. Janeiro de 2004. Disponível em: <http://portal.saude.gov.br/portal/ arquivos/pdf/proposta_pnst_st_2009.pdf >. Acesso em: 04 mai 2013.

BRASIL. Ministério da Saúde. Secretaria de Vigilância em Saúde. Departamento de Vigilância em Saúde Ambiental e Saúde do Trabalhador. Dor relacionada ao trabalho: lesões por esforços repetitivos (LER): distúrbios osteomusculares relacionados ao trabalho (DORT) / Ministério da Saúde. Secretaria de Vigilância em Saúde. Departamento de Vigilância em Saúde Ambiental e Saúde do Trabalhador. Brasília: Ministério da saúde, 2012a.

BRASIL. Ministério da Saúde. Portaria n. 1.823, de 23 de agosto de 2012. Institui a Política Nacional de Saúde do Trabalhador e da Trabalhadora. Brasília, 23 de agosto de 2012b. 
DIAS, E.C. et al. Saúde Ambiental e saúde do trabalhador na atenção primária à saúde, no SUS: oportunidades e desafios. Ciência e Saúde Coletiva, v.14, n.6, p.2061-2070, 2009

ELIAS, M.A.; NAVARRO, V.L. A relação entre o trabalho, a saúde e as condições de vida: negatividade e positividade no trabalho das profissionais de enfermagem de um hospital escola. In: Revista Latino Americana de Enfermagem, Ribeirão Preto, v.14, n.4, jul/ago, 2006.

FONTANELLA, B.J.B; RICAS, J; TURATO, E.R. Amostragem por saturação em pesquisas qualitativas em saúde: contribuições teóricas. In: Caderno de Saúde Pública, v.24, n.1 p.17-27. Rio de Janeiro, jan/2008.

MARTINS, C.O. Repercussão de um programa de ginástica laboral na qualidade de vida de trabalhadores de escritório. 2005. 13f. Tese (Doutorado em Engenharia de Produção) - Centro Tecnológico - Universidade Federal de Santa Catarina, Florianópolis, 2005.

MAZZARINO, A.C.A. Comunicação e educação na re/ construção do indivíduo. Sorocaba, 2011.

MERHY, E.E. A perda da dimensão cuidadora na produção da saúde: uma discussão do modelo assistencial e da intervenção no seu modo de trabalhar a assistência. Campinas, DMPS/FCM/UNICAMP, 1997. Disponível em: <http://www.uff.br/saudecoletiva/professores/merhy/ capitulos-10.pdf>. Acesso em: 04 abr 2013.

O `NEILL, M.J. Os princípios das cadeias musculares na LER/ DORT: O Desafio de Vencer. São Paulo: Madras, 2003.

PEREIRA, V.C. Qualidade de Vida no Trabalho. Monografia apresentada à Universidade Cândido Mendes - Programa de Pós-Graduação em Gestão de Recursos Humanos. Rio de Janeiro, 2006.
RIGOTTO, R.M. Saúde Ambiental \& Saúde dos Trabalhadores: uma aproximação promissora entre o verde e o vermelho. In: Revista Brasileira de Epidemiologia, v.6, n.4, 2003.

SANTOS, A.F. et al. Benefícios da ginástica laboral na prevenção dos distúrbios osteomusculares relacionados ao trabalho. In: Arq. Cienc. Saúde Unipar, Umuarama, v.11, n.2, p. 99-113, maio/ago, 2007.

SOUZA, F.K.N.; ZIVIANI, F. A qualidade de vida no trabalho correlacionada à prática da ginástica laboral. In: Revista Científica do Departamento de Ciências Jurídicas, Políticas e Gerenciais do UNI-BH. Belo Horizonte, vol. III, n. 1, jul2010.

SUCESSO, E.P.B. Relações interpessoais e qualidade de vida no trabalho. Rio de Janeiro: Qualitymark, 2002.

SPILKF, A. et al. O trabalho na contemporaneidade e suas implicações na subjetividade dos trabalhadores. Universidade Federal do Rio Grande do Sul. In: Revista de Ciências Humanas, Florianópolis, EDUFSC, v.43, n.1, p.165179, Abril 2009. 


\section{EDUCAÇÃO POPULAR EM SAÚDE E PRÁTICAS CORPORAIS: CONTRIBUIÇÕES PARA O DEBATE}

Braulio Nogueira de Oliveira Felipe Wachs Igor Carneiro Gomes Glaucia Almeida Mapurunga de Paiva

\section{Introdução}

Muitas vezes, o movimento corporal é tratado de forma utilitarista, com fim em si próprio. Nessas situações, torna-se precípuo o paradigma saúde-doença, em que a criação e manutenção de "corpos saudáveis" gera uma violência ideológica tanto para aqueles considerados sedentários, quanto para os ditos saudáveis. Diante disso, emerge a chamada "nova ordem físico-sanitária" em que a atividade física é disseminada com o fim utilitarista de prevenir doenças, tendo como foco proporcionar benefícios fisiológicos, sendo que esse pensamento conta com apoio e investimentos na forma de políticas públicas, além da iniciativa privada. (FRAGA, 2005)

Esse processo culmina com uma 'patologização' do sedentarismo, em que aquele sujeito que não segue as 
recomendações de tempo e intensidade consideradas adequadas, não somente é considerado sedentário, mas a ele também são atribuídas adjetivações como preguiçoso, irresponsável, ou culpado por uma condição de "não saudável". (WACHS, 2008) Todavia, o que seria o sedentário? Após uma revisão de literatura, encontrase que podem coexistir significações distintas, mas, em geral, por sedentário compreende-se aquele sujeito que não pratica o mínimo recomendado de atividade física. Contudo, atividade física é considerada qualquer atividade humana que tenha um gasto calórico acima do basal, como, por exemplo, levantar, caminhar, escovar os dentes e etc. (PALMA, 2009) De forma que, partindo dessa compreensão, a maioria das pessoas que se consideram sedentárias, com informações diferenciadas, mesmo não sendo necessário aumentar seu nível de atividade física, poderiam questionarse acerca da classificação vigente. (FRAGA, 2005)

O sedentarismo, ao ser pautado pelo modelo biomédico como doença, engendra um processo de "medicalização" das práticas corporais. Neste modelo, elas acabam por ser representadas e ocupar um espaço de significação de "medicamento", como sugere o título de um relevante artigo: "O gosto amargo do exercício como remédio nas pedagogias do medo e da culpa." (QUINT; MATIELLO JÚNIOR, 1999) Essa lógica vem sendo implementada inclusive em receitas médicas, como ocorre no programa denominado: "Exerciseis Medicine"/ "Exercício é remédio" (http://exerciseismedicine.org/).

Alerta-se para os aspectos negativos inerentes ao reducionismo da reprodução de programas de exercícios protocolados, pelo caráter eminentemente políticopedagógico que as práticas corporais possuem. (WACHS, 2008) Nesse sentido, a mera reprodução dessas práticas pode culminar com um distanciamento do sentido do movimento corporal, assim como dos preceitos da pedagogia freireana ${ }^{1}$. Pensar no desenvolvimento das práticas corporais enquanto espaço de cuidado associado à relações de produção de vínculo, autonomização, acolhimento e gestão, implica reconhecê-las como uma tecnologia leve em saúde. (MERHY, 1997; 2002)

Correia, Miranda e Veleradi (2011), ao refletirem suas práticas em Educação Física para idosos, ressaltam a pedagogia freireana enquanto potente colaboradora com as práticas educativas formais e não formais, a qual se configura como uma tecnologia em saúde disparadora de leituras críticas da realidade posta. Nessa perspectiva, considera-se vital que na práxis dos cuidadores dos grupos de práticas corporais, a ação dialética dessa pedagogia, à medida que propõe uma transformação nas convicções postas de caráter político-filosóficas, conspira contra a dominação do pensar e reprodução dos gestos padronizados, portanto, isentos de significação e de busca pela autonomia. (CORREIA; MIRANDA; VELERADI, 2011)

Diante do exposto, o presente texto visa colaborar com o debate acerca da educação popular em saúde atrelada às práticas corporais, enquanto tecnologia leve de cuidado, a partir de uma reflexão teórica resultante de leitura exaustiva e flutuante sobre a interface entre teóricos dessas duas áreas. Acrescenta-se ainda, o acúmulo teórico-prático resultante do Programa de Residência Multiprofissional em Saúde da Família, conduzido pela Escola de Formação em Saúde da Família, chancelado pela Universidade Estadual Vale do Acaraú (UVA), cofinanciado pela prefeitura de Sobral/CE e pelo Ministério da Saúde.

Paulo Freire (1921-1997) foi o criador dessa metodologia, tendo por base os seus processos de alfabetização enquanto conscientização vivenciada. A partir de sua vivência como educador foram produzidas diversas obras, tais como: Educação: prática da liberdade (1967); Pedagogia do oprimido (1968); Cartas à Guiné-Bissau (1975); Pedagogia da esperança (1992); e À sombra desta mangueira (1995). 


\section{O Diálogo Entre a Educação Popular em Saúde e as Práticas Corporais}

Em estudo acerca da história das práticas de educação em saúde, verificou-se que as ações desenvolvidas no período denominado República Velha não eram condizentes com a proposta de promoção da saúde, por possuir foco em patologias específicas. (MARCIEL, 2009) Além disso, ressalta-se na contemporaneidade o surgimento de novos métodos, sendo estes dialógicos e reflexivos, que visam melhorias na condição de saúde da população, tendo destaque a educação popular em saúde e a educação dialógica.

O Brasil é considerado o pioneiro na construção do método da educação popular, a partir do livro "Pedagogia do Oprimido" (FREIRE, 1968), que embora tenha surgido na década de 60, possui muitas contribuições relevantes e atuais. (VASCONCELOS, 2004) Nessa perspectiva, surge um movimento forte na saúde, denominado educação popular em saúde, fruto dessa teoria criada por Paulo Freire, e que visa um alinhamento entre o fazer em saúde e a realidade das comunidades, sendo estas vistas não apenas como população adscrita, mas sim como sujeitos autônomos na tomada de decisão de seu projeto terapêutico. Assim, deixa-se de desenvolver processos de trabalho em saúde "para" o usuário em detrimento de um processo dialógico "com" o usuário.

A educação popular difere da "educação informal", à medida que não se limita a ambientes informais, pois tratase de relações horizontais e circulares, de troca de saberes, reflexivos e vinculados à política emancipatória. Nesse sentido, evidencia-se que há diversas propostas educativas que ocorrem fora do ambiente escolar, mas que conservam os métodos verticalizados da relação educador-educando e, portanto, estão em desacordo com a educação popular em saúde. (VASCONCELOS, 2004)

A cidade de Recife destacou-se nessa área por desenvolver uma política municipal de educação popular em saúde, institucionalizando o movimento de educação popular em saúde. Em um resgate histórico, em que se realizou um recorte da década correspondente aos anos de 2001 a 2010, identificou-se que antes do início do projeto municipal foram evidenciadas demandas como a abordagem normativo-instrumental hegemônica nas práticas de educação em saúde, a fragilidade da educação em saúde nos distritos sanitários e a pouca participação popular nos serviços. (AMORIM, 2010)

Os próprios autores que produzem na perspectiva da educação popular em saúde reconhecem que há muitos avanços em seu desenvolvimento junto aos serviços de saúde, entretanto, tais conquistas não teriam ainda sido suficientes para mudar o modo como o modelo hegemônico vem sendo implantado, justamente pela implicação de uma minoria dos trabalhadores em saúde nesse processo.

Algumas ferramentas importantes para que ocorra uma mudança de cenário, a partir do método da educação popular em saúde, são os veículos de comunicação. Prado et al. (2011), expõem uma experiência vivenciada na ESF em Rio Negro, Mato Grosso do Sul, no período de 2006 a 2009. Nesse caso, as ações em saúde foram desenvolvidas em uma rádio, com a preocupação de identificar demandas da comunidade, evitando realizar, segundo os autores, um programa prescritivo e com foco na doença.

Com o êxito da atividade, a equipe de saúde ampliou o olhar para outras possíveis estratégias de promoção de saúde, conforme referido pelos autores: festa junina (Arraiá do SUS) e outras comemorações, mostra de fotografia, teatro, panfletos, cartazes, faixas, carro de som, cinema na 
Unidade de Saúde da Família e outras. (PRADO et al., 2011) Nessa lógica, questiona-se: é possível desenvolver práticas corporais na perspectiva da educação popular em saúde? Por que não se trabalhar atividades educativas nos grupos de práticas corporais?

Essa lógica assola o pensamento arcaico do profissional de saúde enquanto o único detentor do saber e, por conseguinte, superior ao usuário. A educação popular em saúde surgiu a partir de uma luta dos movimentos sociais pela mudança na atenção à saúde, no sentido de viabilizar uma relação participativa com a população, rompendo com a tradição autoritária dominante. Nesse sentido, ressaltase ainda, a relação existente entre o embate desse método com o autoritarismo dos "doutores"; o desprezo ao saber popular; a imposição de soluções puramente técnicas para problemas sociais; e o modelo biomédico e suas repercussões na atenção à saúde. (VASCONCELOS, 2004)

A prática corporal difere do exercício físico pelo arcabouço teórico-prático, uma vez que possui um alinhamento com a proposta de educação popular em saúde. O movimento não é um fim em si mesmo, mas sim um símbolo de significação social, a partir da cultura corporal do movimento e do desenvolvimento de relações de diálogo e autonomia. Portanto, essa cultura corporal assume não somente um aspecto funcional como se propõe o exercício, avançando para um campo político conhecido por empoderamento.

Esse conceito é trabalhado em diversas áreas, como na Administração e na Economia, sendo que na perspectiva freireana concebe-se a noção de empoderamento comunitário, também conhecido como empoderamento social, em que é pautada a construção de uma conscientização e politização, a partir do conhecimento dialético da realidade direcionada a um processo de libertação/autonomia. (CARVALHO; GASTALDO, 2008; BAQUERO, 2012; CONTRERAS, 2011) Nesse cenário, percebe-se o profundo desafio atrelado ao desenvolvimento de práticas corporais tendo por base esse referencial.

O sentido da "educação empoderadora" pressupõe um papel pujante do professor/profissional de saúde no que concerne a não centralizar as ações em sua própria tomada de decisão, a qual demanda vigorosa capacidade de escuta, além de o usuário não se colocar apenas como "receptor passivo" do que lhe é "transmitido". No que se refere às práticas corporais, essa propositiva manifesta-se ao serem realizados os seguintes questionamentos: "Que atividades você gosta de fazer?"; "Que lazer você costuma realizar?"; "O que inviabiliza essa prática?" Essa abordagem deve superar as afirmações e os apontamentos que culpabilizam o usuário da seguinte forma: "Você deve realizar ao menos 30 minutos, cinco vezes por semana!"; "Faça caminhada, irá melhorar seu sistema cardiorrespiratório!"; "Você não faz porque não quer se cuidar".

Ao refletir acerca do desenvolvimento de práticas corporais, na perspectiva da Saúde Coletiva, Luz (2007) ressalta a necessidade do desenvolvimento de uma consciência sanitária por parte dos profissionais de Educação Física, destacando ainda, uma perspectiva diferente da tradicional, a qual considera-se pertinente enquanto promotora de um alinhamento teórico-conceitual entre práticas corporais e a educação popular em saúde:

[...] Não se trata de "treinar" (caso do desporto) ou de "adestrar" (caso da maioria das ginásticas), talvez nem mesmo de "habilitar" (caso da educação escolar) o corpo dos praticantes para o desempenho de atividades físicas, mas, na maioria das vezes, simplesmente, através da atividade, colocar em contato com seu próprio corpo 
pessoas que jamais se detiveram para 'senti-lo' ou 'ouvi-lo' como algo seu, vivo, pulsante, com capacidades e limites. (LUZ, 2007, p.15)

A educação popular em saúde condiz com essas colocações, assim como avança, no sentido de sugerir o desenvolvimento de uma consciência sanitária por parte dos usuários/alunos dessas práticas corporais, a partir da problematização de situações sociais reais e vivenciadas.

A consciência aqui referida manifesta-se, desde a década de 1970, por meio dos movimentos sociais que buscavam, através da chamada Reforma Sanitária, colaborar com uma transformação das desigualdades; direcionada à melhoria dos direitos sociais básicos (alimentação, transporte, moradia, emprego, entre outros); além de criar uma política científica e tecnológica, propondo inclusive mudanças nas escolas médicas; bem como promover/ fortalecer o desenvolvimento de recursos humanos, suprindo demandas quantitativas, qualitativas e garantindo o acesso de todos a todos os níveis de atenção à saúde. (PAIM, 2008; SILVA, 1986)

A Reforma Sanitária consolidou algumas conquistas relevantes, como uma maior democratização do setor saúde e a própria institucionalização do Sistema Único de Saúde (SUS). Nesse sentido, no que tange à proposta do desenvolvimento de práticas corporais na perspectiva de contribuir com uma percepção crítico/questionadora de caráter transformador da realidade; de um entendimento e ressignificação das práticas; da militância pelos direitos sociais, surgem os questionamentos: é possível? Quais as adversidades?

Para tanto, tendo por base a teoria da educação popular em saúde, tornam-se necessários primordialmente, o diálogo e a autonomia. É destacada a existência de diálogo apenas no lidar "com o outro", assim como sua inexistência na relação "para o outro". À medida que se desenvolve o papel da escuta e da intervenção enquanto via de mão dupla (cuidador e usuário), inclusive "desformalizando" horários específicos para tais abordagens, o papel outrora autoritário do cuidador tende a ser desmistificado, colaborando com a construção do vínculo e de um significado em ser participante daquela atividade. Consequentemente, viabiliza-se o desenvolvimento de uma autonomia inicial, a de se posicionar diante dos acontecimentos, o que tende a uma reflexão posterior e à busca por alternativas no cotidiano, além da autonomia funcional por meio da aptidão física.

Percebe-se um contraste clamoroso entre a proposta de autonomia referida e a expropriação dos saberes sobre o corpo, desenvolvido pelos ditos "experts" no assunto, os quais condizem com o modelo biomédico vigente de determinismo do saber. Numa perspectiva positivista, a solução das necessidades dos indivíduos, bem como as intervenções necessárias, são indicadas pelo profissional de Educação Física de modo não dialógico, situação em que se põe o foco na doença corporal e no paciente em detrimento da pessoa. (SAMPAIO; LUZ, 2009)

Ressalta-se assim, o diálogo enquanto saber primordial e fundante da educação popular. Estratégias participativas evitam que gestos e movimentos sejam feitos desnecessariamente, no sentido de colaborar com a percepção crítica-emancipatória defendida, certos de que mesmo desvinculados da política ocorrem melhorias biopsicossociais relevantes, embora com enfoque fisiológico. O que se propõe aqui é justamente superar essa vertente. Para Correia, Miranda e Veleradi (2011), o diálogo e a autonomia não são recursos didáticos. Ao contrário, em seu ensaio, os consideram elementos fundamentais para 
uma filosofia do conhecimento apoiada num humanismo militante compromissado com a libertação de homens e mulheres.

O referido diálogo estende-se ao campo das políticas públicas, estando aí incluída a Saúde Coletiva, cujo exemplo é a criação de grupos de caminhada. Essas políticas ou novas intervenções, pautadas nas práticas corporais, desenvolvem-se ou são ofertadas/criadas "para" o usuário ou "com" o usuário? Caso a resposta seja "com", o diálogo certamente está posto, o que inclui necessariamente uma significação desse espaço, de modo que o usuário/ aluno, que pressupõe enquanto requisito um mínimo de autonomia para essa tomada de decisão, a qual não pode ser contemplada meramente com repetições do movimento do "professor-instrutor".

Segundo Vasconcelos (2004), a educação popular é um modo de participação dos agentes tidos como eruditos, aqui denominados de cuidadores, desmistificando a ideia das relações de poder hierarquizado. São eles, os professores, padres, profissionais de saúde, entre outros, envolvidos no trabalho pedagógico individual e grupal relacionado à participação popular, promovendo o crescimento da capacidade de análise crítica sobre a realidade e colaborando com as estratégias de luta e enfrentamento de determinadas situações.

Na perspectiva das práticas corporais, ocorre uma busca pela autonomia dos sujeitos e o desenvolvimento de atividades com alguma significação social. A ideia aqui defendida difere da concepção cartesiana, muitas vezes, exaltada em algumas situações: "pratiquei atividade física, aumentei meu gasto calórico, estou mais saudável!". Não se trata dessa significação reducionista, afinal, o que se pode dizer a esse respeito?
Em determinada situação no cenário de práticas da Residência Multiprofissional em Saúde da Família, ao questionar os educandos a respeito de uma abdução de quadril, fiz o seguinte questionamento: "alguém sabe o objetivo desse exercício?". Por sua vez, uma senhora educanda respondeu: "é praquando eu for subirno moto-táxi eu não cair". Essa resposta surpreende, ao passo que muda o enfoque do sentido que o exercício carrega (desenvolver a resistência muscular localizada da musculatura abdutora da perna), para um significado sucumbido de sentimentos, afetos, cuidado e até mesmo funcionalidades.

São reconhecidos os diversos avanços estabelecidos na perspectiva da educação popular em saúde, com a efetivação de diversas ações nesse sentido, no entanto, esse esforço vem sendo insuficiente para transformação do modelo biomédico, visto que essa mudança envolve além de questões conjunturais, a adesão de mais profissionais acerca da metodologia em seus processos de trabalho. (VASCONCELOS, 2004) No que concerne às práticas corporais vem sendo da mesma forma. Muitos profissionais desenvolvem exercícios físicos, com relevantes benefícios para os praticantes, porém, com amplitude que de fato poderia ser potencializada a partir de uma compreensão ampliada entre as práticas corporais e a educação popular em saúde. 


\section{Reflexões finais}

A educação popular em saúde compreende um movimento relevante no que concerne aos tensionamentos inerentes a uma transformação sociopolítica e cultural da realidade brasileira, sendo já reconhecido enquanto integrante de políticas sociais e políticas públicas de saúde da população. Tendo raízes na educação, não é possível delimitar a estruturação desse movimento, no sentido de estabelecer um modelo a ser seguido, visto que um dos princípios de sua teoria é justamente o diálogo, e, por conseguinte, uma adequação à realidade de modo a ser significativo para os sujeitos envolvidos.

Embora tenha o caráter explicitado acima, destacamse alguns apontamentos a partir das leituras e vivências realizadas, direcionados a colaborar com o debate em questão, ampliando, desse modo, o escopo e a abrangência da educação popular em saúde no âmbito das práticas corporais. As reflexões eliciadas permeiam a postura de diálogo, a promoção da autonomia.

O diálogo envolve uma adequação à realidade e a linguagem corporal dos sujeitos envolvidos. Recomendase, assim, o estabelecimento dessa ferramenta como forma de não impor atividades, partindo da compreensão que essa seria a principal maneira de desvelar quais práticas corporais possuem algum significado para o educando.

A autonomia enquanto outro elemento básico da educação popular em saúde deve ser desenvolvida não somente na perspectiva da autonomia funcional, tendo a prerrogativa de avançar no sentido da autonomia política, que pode ser trabalhada por meio de práticas reflexivas, através de questionamentos, durante as práticas, quanto às experiências vividas pelos educandos; ou ainda, com uma proposta de atividades contextualizadas com a realidade dos sujeitos envolvidos.

Considerou-se o alinhamento entre as práticas corporais e a educação popular em saúde enquanto um debate em aberto, em que o cuidador/profissional lida com muitas dificuldades, fundadas na necessidade de desconstrução de práticas fomentadas historicamente, para construção da práxis. Diante disso, é preciso uma maior apropriação dessa tecnologia, no sentido de promover subsídios para essa transformação social da atenção em saúde, principalmente no que se refere às práticas corporais.

\section{Referências}

AMORIM, E.G.S. Educação Popular em Saúde no Recife: sistematização de experiências desenvolvidas no DS VI de 2001 a 2010. TCC (Especialização em Gestão de Sistemas e Serviços de Saúde). Departamento de Saúde Coletiva, Centro de Pesquisas Aggeu Magalhães, Fundação Oswaldo Cruz, Recife, 2010.

BAQUERO, R.V.A. Empoderamento: instrumento de emancipação social? - uma discussão conceitual. Revistadebates, Porto Alegre, v. 6, n. 1, p.173-187, jan.-abr. 2012.

CARVALHO, S.R.; GASTALDO, D. Promoção à saúde e empoderamento: uma reflexãoa partir das perspectivas crítico-social pós-estruturalista. Ciência \& Saúde Coletiva, Rio de Janeiro, v.13, supl.2, p.2029-2040, dez/2008.

CONTRERAS, H.S.H. A educação popular para além do capital social: a conscientização como possibilidade de desreificação do ser social. 170f. Dissertação (Mestrado) Universidade Tuiuti do Paraná, Curitiba, 2011. 
CORREIA, M.S.; MIRANDA, M.L.J.; VELERADI, M. A prática da educação física para idosos ancorada na pedagogia freireana: reflexões sobre uma experiência dialógicaproblematizadora. Movimento, Porto Alegre, v.17, n.04, p.281-297, out/dez, 2011.

EXERCÍCE IS MEDICINE. C2008. Disponível em: <http:// exerciseismedicine.org/>. Acesso em: 30 abr 2014.

FRAGA, A.B. Exercício da informação: governo dos corpos no mercado da vida ativa. Porto Alegre: UFRGS, 2005. Tese (Doutorado) - Programa de Pós-Graduação em Educação, Faculdade de Educação, Universidade Federal do Rio Grande do Sul, 2005.

LUZ, M.T. Educação Física e saúde coletiva: papel estratégico da área e possibilidades quanto ao ensino na graduação e integração na rede de serviços públicos de saúde. In: FRAGA, A.B. e WACHS, F. Educação Física e Saúde Coletiva. Políticas de Formação e Perspectivas de Intervenção. Porto Alegre: Editora da UFRS, 2007.

MACIEL, M.E.D. Educação em saúde: conceitos e propósitos. Cogitare Enfermagem, Curitiba, v.14, n.4, p.773-776, out./ dez.2009.

PAIM, J.S. A reforma sanitária brasileira e o Sistema Único de Saúde: dialogando com hipóteses concorrentes. Physis, Rio de Janeiro, v.18, n.4, p.625-644, 2008.

PALMA, A. Exercício Físico e Saúde; Sedentarismo e Doença: Epidemia, Causalidade e Moralidade. Motriz, Rio Claro, v.15, n.1, p.185-191, jan./mar. 2009.

PRADO, E.V., et. al. Construindo cidadania: educação popular em saúde via rádio comunitária. Rev APS. v.14, n.4, p.497-501, out/dez, 2011
QUINT, F.O.; MATIELLO JUNIOR, E. O gosto amargo do exercício como remédio nas pedagogias do medo e da culpa. Revista Brasileira de Ciências do Esporte, Florianópolis, v.21, n.1, p.867-872, set. 1999.

SAMPAIO, R.F.; LUZ, M.T. Funcionalidade e incapacidade humana: explorando o escopo da classificação internacional da Organização Mundial da Saúde. Cad. Saúde Pública, Rio de Janeiro , v.25, n.3, mar.2009.

SILVA, L.A.S.R. A Educação Médica e a Reforma Sanitária. Cadernos de Saúde Pública, Rio de Janeiro, v.2, n.4, p.493504, 1986.

VASCONCELOS, E.M. Educação Popular: de uma prática alternativa a uma estratégia de gestão participativa das políticas de saúde. Physis, Rio de Janeiro, v.14, n.1, p.67-83, 2004.

WACHS, F. Educação física e mental: uma prática de cuidado emergente em Centros de Atenção Psicossocial (CAPS). Porto Alegre: UFRGS, 2008. Dissertação (Mestrado) - Programa de Pós-Graduação em Ciências do Movimento Humano, Porto Alegre, BR-RS, 2008. 


\title{
ENTRE MÃOS, GESTOS E OLHOS: A COMUNICAÇÃO ENTRE O ENFERMEIRO E O DEFICIENTE AUDITIVO NA ESTRATÉGIA SAÚDE DA FAMÍLIA
}

\author{
Danilo Sampaio Souza \\ Cilene Maria Freitas \\ André Luis Façanha da Silva
}

\section{Introdução}

Dentre suas principais funções, incumbe à Atenção Primária à Saúde (APS) a função de coordenar o cuidado e ordenar as redes de atenção à saúde. Assim, constituise como o primeiro contato entre os usuários e o sistema de saúde. Desse modo, busca proporcionar equidade na distribuição dos recursos do Sistema Único de Saúde (SUS), melhoria na saúde da população e a participação popular. (STARFIELD, 2002)

No que diz respeito à atenção à saúde da pessoa com deficiência, as unidades de saúde da APS tem a função de prestar assistência tanto a esse como a qualquer outro usuário, de maneira que não gere segregação, respeitando 
o princípio da equidade no SUS. (BRASIL. MINISTÉRIO DA SAÚDE, 2010)

A Estratégia Saúde da Família (ESF), adotada no Brasil como forma de reorientação da APS, mostra-se como um campo importante para o desenvolvimento de práticas de atenção à saúde voltada à pessoa com deficiência, particularmente no que se refere à circulação e participação social, sob a ótica de inclusão e dos direitos de cidadania.

No Brasil, segundo o Censo Demográfico de 2010, realizado pelo Instituto Brasileiro de Geografia e Estatística (IBGE), o país apresentava $23,92 \%$ de sua população referindo alguma deficiência; dentre esses, $21,31 \%$ com algum tipo de deficiência auditiva. (IBGE, 2010) Diante desses dados, torna-se importante a existência de profissionais capacitados para atender os indivíduos com diversas necessidades que buscam atendimento no SUS. (CORRÊA, 2010) Vale ressaltar a categoria da Enfermagem enquanto profissão, cuja essência e especificidade é o cuidado ao ser humano, individualmente, na família ou na comunidade. (ROCHA, 2000) Dentre os profissionais de saúde, os enfermeiros estão entre os que mantêm maior contato com os usuários dos serviços de saúde. (ROSENSTOCK; NEVES, 2010)

A respeito da atuação do enfermeiro no cuidado das pessoas com deficiência e especialmente, no cuidado das pessoas surdas, estudos sugerem que as dificuldades na assistência à saúde a esse público devem-se principalmente ao despreparo, por haver uma segregação histórica desses indivíduos, por serem considerados inválidos. (FRANÇA; PABLIUCA, 2009)

Observamos que a relação entre o profissional e as pessoas com deficiência auditiva requer uma inter-relação que possibilite criar meios de produzir cuidados em saúde, de tal forma que se estabeleçam comunicação e tradução entre as necessidades de saúde percebidas pelo profissional e sentidas pelo usuário, onde a superação da deficiência seja uma responsabilidade compartilhada. Assim, é importante estabelecer formas diferenciadas de comunicação que contribuam para a criação de tecnologias leves em saúde, à medida que o vínculo, os afetos e o sentir mobilizem o agir em saúde, e que venham a garantir a participação do sujeito com deficiência auditiva e seu acesso aos serviços de saúde. Vale ressaltar que as tecnologias leves em saúde não são menos complexas que as demais, apenas demandam menor densidade tecnológica. (MERHY, 2002)

A cultura e a linguagem das pessoas que convivem com deficiência auditiva são diferentes e devem ser conhecidas e respeitadas, de acordo com os princípios éticos. A comunicação com essa demanda surge como um desafio, principalmente para os profissionais que prestam assistência à saúde. (ARAÚJO, 2007)

A Língua Brasileira de Sinais (LIBRAS) é um sistema linguístico visual-espacial, ou seja, faz uso da visão e do espaço, em vez da audição e do som. Seus sinais são formados pela configuração de mãos e movimentos associados a pontos de referência no corpo e no espaço, que podem vir ou não acompanhados de expressão facial. (CARMOZINE, 2012)

A opção pela temática decorreu de vivências pessoais e profissionais do pesquisador principal deste estudo. $\mathrm{Na}$ experiência, enquanto fonoaudiólogo inserido na Residência Multiprofissional em Saúde da Família, emergiram algumas indagações, que buscamos responder nesse estudo: 1) Quais as dificuldades encontradas pelos enfermeiros da ESF no atendimento às pessoas que convivem com deficiência auditiva? 2) Que estratégias utilizam para tornar a comunicação e a assistência eficazes? 
$O$ presente estudo tem como objetivo investigar a percepção dos enfermeiros da ESF quanto à importância da comunicação com a pessoa que convive com deficiência auditiva, em um Centro de Saúde da Família, na sede do município de Sobral, Ceará. Para tal finalidade, buscamos averiguar as dificuldades de comunicação dos enfermeiros e identificar estratégias de comunicação utilizadas pelos profissionais de enfermagem para prestarem assistência às pessoas que convivem com deficiência auditiva na ESF.

Reconhecemos a relevância do estudo pela identificação de ações voltadas para a capacitação de profissionais para o atendimento, bem como por assegurar o acesso de acordo com a complexidade que cada caso requeira e, desse modo, satisfazer as necessidades dos usuários no tocante à saúde. Somente pela comunicação efetiva poderá o profissional ajudar o usuário a relatar seus problemas, enfrentá-los, demonstrar sua participação na experiência e encontrar alternativas para solucioná-los.

\section{Percurso metodológico}

Trata-se de um estudo exploratório-descritivo, de abordagem qualitativa. Para Gil (2007), o estudo exploratório proporciona maior familiaridade com o problema, com vistas a torná-lo mais explícito ou a constituir hipóteses. 0 estudo descritivo tem como objetivo primordial a descrição das características de determinada população ou fenômeno ou, ainda, o estabelecimento de relação entre variáveis.

Segundo Bosi (2012), a pesquisa qualitativa caracteriza-se por objetos relacionados à subjetividade e, portanto, não quantificáveis, tomando como material a linguagem em suas várias formas de expressão. Aplica-se ao estudo da história, das relações, das representações, das crenças, das percepções e das opiniões. (MINAYO, 2004)

O estudo ocorreu em um Centro de Saúde da Família, na sede do município de Sobral, estado do Ceará. O período da coleta das informações compreendeu o mês fevereiro de 2014.

Os sujeitos do estudo foram seis dos doze enfermeiros que trabalharam no CSF selecionado para esse estudo, no período de 2012 a 2014. Desse total de sujeitos, apenas um enfermeiro se opôs à gravação, preferindo escrever no próprio roteiro da entrevista a sua opinião quanto às perguntas. Portanto, nenhum dos convidados se opôs a participar. Assim, adotamos os seguintes critérios de inclusão: enfermeiros que já tiveram contato com pessoas de ambos os sexos que convivem com deficiência auditiva, sem restrição de idade, ou comunicação utilizada no período acima citado; e como critérios de exclusão, os enfermeiros que estivessem afastados. Logo, contamos com seis profissionais enfermeiros que foram entrevistados considerando-se a saturação teórica das informações, de acordo com os pressupostos de Fontanella et al. (2011).

Essa investigação utilizou como técnica de coleta de informações a entrevista semiestruturada, a qual, além de valorizar o comparecimento do pesquisador, oferece todas as perspectivas possíveis para que o informante alcance a liberdade e a espontaneidade necessárias. (TRIVIÑOS, 2001) A entrevista parte de alguns questionamentos básicos que são de interesse do objeto e objetivos da pesquisa, e permite que o informante se expresse livremente dentro do foco principal estabelecido pelo pesquisador.

As entrevistas foram previamente agendadas conforme a disponibilidade dos participantes e conduzidas pelo pesquisador principal, de forma individualizada e orientada pelas seguintes perguntas: 1) Quais as 
dificuldades encontradas por você durante o atendimento ao usuário que convive com deficiência auditiva? 2) Quais estratégias ou forma de comunicação você utilizou durante o seu atendimento ao usuário que convive com deficiência auditiva? 3) Em sua opinião, qual a importância de se ter uma boa comunicação com o usuário que convive com deficiência auditiva?

As entrevistas foram realizadas na própria unidade de saúde e gravadas com permissão prévia dos participantes.

Para avaliação do material, optamos pela técnica da análise temática. Assim, de acordo com Minayo (2004), identificamos os núcleos de sentido, que compõem uma comunicação cuja presença ou frequência signifiquem alguma coisa para o objetivo visado. Desse modo, os núcleos de sentidos desse estudo são: dificuldades de comunicação; estratégias de comunicação e importância da comunicação.

\section{Dificuldades de comunicação}

Nessa sessão, discutiremos as informações empíricas que tratam do núcleo de sentido dificuldades de comunicação, que revela as principais barreiras e desafios para o processo comunicativo. Diante disso, ressaltamos que a dificuldade de comunicação com deficientes é um fenômeno presente no dia a dia do profissional na ESF, sendo a principal causa disso a falta de preparo ou de formação para lidar com esses pacientes, como relatado pelos entrevistados a seguir:

A dificuldade é de não ter tido treinamento por parte da estratégia Saúde da Família, de como se comportar e como conversar com esses pacientes. (Entrevistado M)
Não tenho o treinamento, a capacitação em trabalhar com o deficiente auditivo. (Entrevistado T)

A falta de preparo para lidar com ele, porque, na verdade, a gente não passa por nenhum processo de preparo, nem durante o curso da graduação e também durante o trabalho, a gente não passa por nenhuma atualização. (Entrevistado G).

Conforme observamos nas falas dos entrevistados, é grande a necessidade de serem desencadeados processos de educação em serviço, tendo em vista a premência do auxílio no atendimento dos usuários, diariamente.

É necessário comunicar-se de modo consciente, empenhando-se para decodificar, decifrar e perceber o significado da mensagem que o paciente envia. Só assim poderão ser identificadas suas necessidades e a comunicação efetiva fará com que o profissional de enfermagem possa ajudar o paciente a conceituar seus problemas, a enfrentálos, a visualizar a experiência vivida e até auxiliá-lo a encontrar novos padrões de comportamento. (CARDOSO; RODRIGUES; BACHION, 2006)

O processo de produção da atenção à saúde inicia-se, na maioria das vezes, a partir da capacitação de seus trabalhadores, com o objetivo de melhorar as competências profissionais. As atividades desenvolvidas com esse fim são diversas e possuem denominações diversas: de capacitações, treinamentos ou cursos. São eventos realizados de forma pontual, às vezes emergencial, ou, até mesmo, através de processos mais estruturados e contínuos, inclusive de formação, utilizando-se das variadas concepções existentes. (SOUZA et al., 1991)

Nessa perspectiva da formação, vale ressaltar a educação permanente em saúde. Essa pode ser 
compreendida como sendo um processo educativo contínuo, de revitalização e superação pessoal e profissional, de modo individual e coletivo, com objetivo de qualificação, reafirmação ou reformulação de valores, construindo relações integradoras entre os sujeitos envolvidos para uma praxe crítica e criadora. (FEUERWERKER, 2001)

Investir na formação de profissionais para a abordagem do indivíduo surdo favorece a assistência com igualdade social e a conquista de um espaço para o exercício da cidadania entre os deficientes auditivos. (BARBOSA et al., 2003) Assim, torna-se necessário dispor de ferramentas que possibilitem esse diálogo, uma vez que essa questão, além da humanização, abrange as questões éticas do cuidar. O domínio da comunicação não verbal instrumentaliza o profissional para uma assistência de melhor qualidade, à medida que interpreta com maior amplitude as mensagens emitidas por seus clientes, elevando sua capacidade de satisfazer as necessidades por eles apresentadas.

A educação permanente, portanto, constitui-se em ferramenta de gestão e de atenção à saúde que possibilita a mudança na formação dos profissionais da ESF, no sentido de melhorar suas práticas de atenção. Vale ressaltar, desse modo, a educação permanente enquanto processo educativo e contínuo efetivado no município de Sobral.

De acordo com a Política Nacional de Atenção à Saúde Auditiva (2004), os resultados das ações decorrentes dessa política, na atenção básica e nos serviços de média e alta complexidade, devem promover uma ampla cobertura no atendimento aos portadores de deficiência auditiva no Brasil, com aprimoramento da gestão e da disseminação de informações, bem como uma visão dinâmica do estado de saúde das pessoas portadoras de deficiência auditiva. Além disso, a capacitação e a educação continuada das equipes de saúde em todos os âmbitos de atenção, envolvendo profissionais de diferentes níveis, devem estar alicerçadas nas diretrizes do SUS e nos polos de educação permanente em saúde.

\section{Estratégias de comunicação}

É possível observar várias estratégias utilizadas pelos enfermeiros na tentativa de estabelecer comunicação no atendimento ao deficiente auditivo. Essas estratégias foram sintetizadas na fala de um entrevistado.

(...) uso de gestos com o uso das mãos, olhando e falando pausadamente, e procurando verbalizar para que ele conseguisse alguma leitura labial. (Entrevistado G)

Basicamente, os deficientes auditivos comunicamse de modo não verbal, pois eles não conseguem oralizar as palavras. Entre os surdos, a comunicação não verbal é usada de forma mais consciente e objetiva, com bom nível de interação em grupo. Na maioria das vezes, a linguagem dos surdos é gestual e global, ou seja, um único tipo de gesto pode significar uma ideia completa, como também alguns gestos podem comunicar uma única ação. (NOGUEIRA et al., 2000)

A mímica é uma estratégia de comunicação compensatória, uma vez que o movimento, o gestual e as expressões faciais são percebidos pela visão. Porém, a função simbólica da mímica gestual nem sempre é compreendida devido ao seu surgimento em época primitiva e às alterações sofridas com o passar dos séculos, podendo cada indivíduo interpretar os gestos a partir da sua forma de pensar.

A utilização da leitura labial é viável na interação entre o ouvinte e o surdo, mas não é responsável pela 
compreensão propriamente dita, devido ao fato de a pessoa surda ter que manter foco constante naquele com quem se comunica por conta de que qualquer mudança na posição de ambos os rostos leva à perda de informações. Contudo/Apesar disso, a leitura labial é muito utilizada e superestimada, podendo gerar problemas específicos no relacionamento entre paciente e enfermeiro. (BOTELHO, 1999)

Uma das formas de comunicação com o deficiente auditivo, passível de sucesso, seria portanto, a linguagem de sinais, considerada um elemento muito valioso para a comunidade dos surdos, e também um instrumento muito útil para educadores, para a família do surdo e para outros profissionais. (CICCONE, 1990)

Porém, apenas um dos enfermeiros entrevistados relatou conhecer a LIBRAS, ficando evidente que a maioria dos entrevistados não conhecem e nem dominam a LIBRAS, sequer a utilizam no atendimento ao deficiente auditivo.

Identificamos um estudo que aponta para a carência na utilização das LIBRAS por parte dos profissionais de saúde e que relata que o comportamento não verbal dos profissionais expressa distanciamento e pouca inclinação para a interação pessoal. (BARBOSA et al., 2003) Os autores também afirmam que a dificuldade de comunicação encontrada pelos pacientes surdos no serviço de saúde, principalmente entre a equipe de enfermagem, impede a eficiente interação, responsável pela qualidade na assistência.

Quando os pacientes nos dizem o que compreendem como cuidar, estão nos lembrando como devemos nos comunicar com eles, apontando para a importância da comunicação não verbal. A linguagem do corpo fala o que, muitas vezes, a nossa própria fala não diz. Nem sempre o profissional da área de saúde tem a consciência de que, ao falarmos em comunicação, não falamos apenas das palavras expressas para a outra pessoa - que podem ser dimensionadas como comunicação verbal. (SILVA, 2002) Até podemos afirmar que quando falamos de relacionamento interpessoal, a comunicação verbal, sozinha, não existe, pois além dela existe a maneira como falamos - que podemos chamar de paraverbal: os silêncios e grunhidos que utilizamos ao falar, as pausas que fazemos entre as frases e palavras, a ênfase que colocamos na voz.

\section{Importância da comunicação}

Durante as entrevistas foi possível observar que os enfermeiros conhecem e sabem da importância de uma boa comunicação no atendimento ao paciente auditivo no que se refere ao cuidado:

É fundamental porque é um usuário que muitas das vezes, que necessita de todo os cuidados que a gente oferta para todas as pessoas, a comunicação é fundamental para saber se a mensagem que a gente passou foi eficiente e se foi realmente compreendida para que ele possa adotar isso e ter um impacto no que a gente pretende. (Entrevistado $\mathrm{G}$ )

Pra que venha ter a resposta satisfatória na verdade dele comigo, para saber se eu compreendi e especialmente se vai ser resolutivo do que ele veio atrás. (Entrevistado T)

Um melhor atendimento e compreensão acerca das necessidades e demandas do deficiente auditivo, um atendimento de qualidade. (Entrevistado J) 
É importante compreender o paciente diante de suas necessidades individuais, avaliando seus aspectos psíquicos e orgânicos, para que a sistematização da assistência de enfermagem seja feita de forma adequada. (MACHADO, 2006)

A comunicação estabelecida com o paciente é um dos mais valiosos aspectos do cuidado de enfermagem, oferecendo subsídios para uma assistência eficiente. (GROSSI; SANTOS, 2008) É através dela que conseguimos criar vínculos com o usuário e a família, além de fornecer um atendimento mais humanístico, voltado especialmente para as mais diversas necessidades de cada cliente.

A assistência de enfermagem, no contexto dos cuidados paliativos, deve considerar o paciente um ser único, complexo e multidimensional: biológico, emocional, social e espiritual. Esse tipo de cuidado, integral e humanizado, só é possível quando o enfermeiro faz uso de diversidades de comunicação para que perceba, compreenda e empregue a comunicação verbal e não verbal. (ARAÚJO; SILVA, 2004)

A dificuldade de comunicação com os profissionais da saúde é claramente percebida quando os surdos procuram atendimento nessa área. As imposições para adaptaremse ao sistema são grandes e, não conseguindo, estão absolutamente exclusos. (CHAVEIRO; BARBOSA, 2005) A necessidade desse público, de ser compreendido pelos profissionais de saúde, torna-se visível nos seus relatos. A falta de intérpretes de LIBRAS constitui uma barreira nas instituições de saúde do Brasil, o que torna ainda mais complicada a vida das pessoas com surdez que procuram atendimento ou que solicitam ajuda nesses locais.

No processo de comunicação, a partir do momento em que o receptor da mensagem transmitida pelo emissor torna-se vulnerável e não consegue entender efetivamente o que lhe é dito, há o comprometimento desse processo e, por consequência, a resposta pode não ser a adequada ou esperada. (FRENK, 1985) Quando esse evento aplica-se à comunicação entre o profissional de saúde e o paciente, fatores como satisfação com o atendimento, aderência ao tratamento, confiança no profissional de saúde, resolução dos sintomas, qualidade de vida, situação de saúde e até mesmo, mortalidade, podem ser afetados. (BECK, 2002)

A comunicação é uma importante ferramenta para o profissional da saúde no diagnóstico e no tratamento, pois fazem parte dele instruções verbais de variados procedimentos, cujo resultado pode ser comprometido pela não compreensão das partes envolvidas. (CHAVEIRO; BARBOSA; PORTO, 2008) Há, portanto, a necessidade de uma melhor comunicação dos profissionais com os pacientes surdos, porém, ela continua negligenciada nos sistemas de saúde. Vale lembrar ainda, que o sucesso na comunicação com os pacientes surdos depende das características individuais de cada pessoa surda, relacionadas às suas necessidades comunicativas.

Foi possível então, evidenciarmos em todas as falas, a importância de se ter a companhia de um familiar durante a consulta, para o apoio à comunicação. Isso/Fato que prova a dificuldade da comunicação do enfermeiro com o deficiente auditivo e da ausência de profissionais qualificados para tanto. 


\section{Considerações finais}

Este estudo demonstrou que os enfermeiros da ESF enfrentam dificuldades no que diz respeito à informação prestada aos deficientes auditivos e na compreensão desses pacientes, a partir de sua forma de comunicar-se; e que esses profissionais da saúde entendem a necessidade de adquirir o conhecimento acerca dessas habilidades comunicativas através de formações específicas. Para vencer essas barreiras, os profissionais procuram empregar diferentes estratégias, utilizando-se do olhar, das mãos, dos gestos e da fala pausada, bem como de uma leitura labial, na tentativa de um atendimento, o que não garante sua eficácia na comunicação.

É importante e necessária a formação profissional para o atendimento ao deficiente auditivo, principalmente no que diz respeito à promoção de uma assistência humanizada e focalizada no contexto de uma sociedade mais inclusiva, tornando-se evidente a necessidade de uma programação voltada para a capacitação dos enfermeiros no atendimento ao deficiente auditivo, fundamental na determinação da qualidade do cuidado a esses pacientes. Nesse sentido, é pujante investir na formação em Libras para as Equipes de Saúde da Família.

Diante dos achados, identificamos que urge a necessidade de uma consciência crítica e reflexiva sobre a importância de se ter uma boa comunicação com o deficiente auditivo, para a diminuição das barreiras de acesso do deficiente com o enfermeiro, de tal forma que possibilite uma nova abordagem ao atendimento, na busca pelo vínculo, pela promoção da saúde e pelo apoio ao deficiente auditivo, sendo, portanto, um ato condizente com o trabalho na perspectiva das tecnologias leves em saúde.
Entender o deficiente auditivo é ir além; é se desprender das nossas linguagens e culturas para adentrar em outro mundo, que possui cultura e linguagens diferentes. Nesse contexto, um simples olhar pode significar muitas palavras, pois a comunicação é um dos caminhos que levam ao cuidado, ao apoio; é através do diálogo que podemos perceber o outro e como ele se mostra; é através dos seus gestos que podemos entender o que o deficiente auditivo nos traz, no sentido de apoiá-lo e perceber suas necessidades e anseios.

\section{Referências}

ARAÚJO, M.M.T. et al. A comunicação não verbal enquanto fator iatrogênico. In: Rev Esc Enferm USP, São Paulo, v.41, n.3, 2007.

ARAÚJO, M.M.T.; SILVA M.J.P. Communication with dying patients: perception of ICU nurses in Brazil. In: J Clin Nurs, v.13, n.2, 2004.

BARBOSA, M.A. et al. Língua brasileira de sinais: um desafio para a assistência de enfermagem. In: Rev. enferm. UERJ, v.11, n.3, 2003.

BECK, R.S. et al. Physician-patient communication in the primary care office: a systematic review. In: J Am Board Fam Pract. v.15, n.1, 2002.

BONILHA, A.L.L. Reflexões sobre análise em pesquisa qualitativa [editorial]. In: Revista Gaúcha de Enfermagem, v.33, n.1, 2012.

BOSI, M.L.M. Pesquisa qualitativa em saúde coletiva: panorama e desafios. In: Ciência \& Saúde Coletiva, Rio de Janeiro, v.17, n.3, 2012. 
BOTELHO, P. Educação inclusiva para surdos: desmistificando pressupostos. In: I Seminário Internacional Sociedade inclusiva; 1999, Set; Belo Horizonte.

BRASIL. Ministério da Saúde. Portaria № 2.073/GM, de 28 de setembro de 2004. Institui a Política Nacional de Atenção à Saúde Auditiva. Diário Oficial da República Federativa do Brasil. 2004.

Atenção à saúde da pessoa com deficiência no Sistema Único de Saúde - SUS. Secretaria de Atenção à Saúde. Departamento de Ações Programáticas Estratégicas. 1.ed. 1. reimp. - Brasília: Ministério da Saúde, 2010.

CARDOSO, A.H.A.; RODRIGUES, K. G.; BACHION, M. M. Percepção da pessoa com surdez severa e/ ou profunda acerca do processo de comunicação durante seu atendimento de saúde. In: Revista Latino-Americana de Enfermagem, Ribeirão Preto, v.14, n.4, ago. 2006.

CHAVEIRO, N.; BARBOSA M.A. Assistência ao surdo na área de saúde como fator de inclusão social. In: Rev. Esc. Enferm. USP, São Paulo, v.39, n.4, 2005.

CHAVEIRO, N. et. al. Revisão de literatura sobre o atendimento ao paciente surdo pelos profissionais da saúde. In: Rev. Esc. Enferm. USP, São Paulo, v.42, n.3, 2008.

CICCONE, M. Comunicação total: introdução - estratégia - a pessoa surda. Rio de Janeiro: Cultura Médica; 1990.

CORRÊA, C.S. et al. O despertar do enfermeiro em relação ao paciente portador de deficiência auditiva. In: Rev. De Pesq.: cuidado é fundamental. v.2, n.2, abr./jun. 2010.

FRANCA, I.S.X.; PAGLIUCA, L.M.F. Inclusão social da pessoa com deficiência: conquistas, desafios e implicações para a enfermagem. In: Rev. Esc. Enferm. USP, São Paulo, v.43, n.1, mar. 2009.
FRENK, J. El concepto y la medición de accesibilidad. In: Salud Pública Méx. v. 27, n. 5, set./out. 1985.

FEUERWERKER, L.M.C. Estratégias para a mudança da formação dos profissionais de saúde. Cadernos ESP, Fortaleza, v. 2, n. 4, dez. 2001.

FONTANELLA, B.J.B. et al. Amostragem em pesquisas qualitativas: proposta de procedimentos para constatar saturação teórica. In: Cad. Saúde Pública, Rio de Janeiro, v.27, n.2, fev, 2011.

GIL, A.C. Como elaborar projetos de pesquisa. 4ed. São Paulo: Atlas; 2007.

IBGE, Censo Demográfico 2010. Disponível em: <ftp:// ftp.ibge. gov.br/Censos/Cen so_Demografico_2010/ Caracteristicas_Gerais_Religiao_Deficiencia/ caracteristicas_religiao_deficiencia.pdf $>$. Acesso em: $14 \mathrm{fev}$ 2014.

MACHADO, M.H. Perfil dos médicos e enfermeiros do Programa de Saúde da Família no Brasil. Brasília: Ministério da Saúde, 2006. 146p.

MERHY, E.E. Saúde: cartografia do trabalho vivo em ato. São Paulo: Hucitec; 2002.

MINAYO, M.C.S. O desafio do conhecimento: pesquisa qualitativa em saúde. 8ed. São Paulo: Hucitec, 2004.

NOGUEIRA R.A, et. al. Interpretação da comunicação nãoverbal de um grupo de surdos. In: Rev RENE, v.1, n.1, p. 41-45, 2000.

ROCHA, S.M.M.; ALMEIDA, M.C.P. O processo de trabalho da enfermagem em saúde coletiva e a interdisciplinaridade. In: Rev. Latino-Amer. de Enfermagem, Ribeirão Preto, v.8, n.6, p.96-101, dez. 2000. 
ROSENSTOCK, et. al. Papel do enfermeiro da Atenção Primária à Saúde de saúde na abordagem ao dependente de drogas em João Pessoa, PB, Brasil. In: Rev. bras. enferm. Brasília, v.63, n.4, ago. 2010.

SOUZA, A.M. et al. Processo educativo nos serviços de saúde. Brasília: Organização Pan-Americana de Saúde OPS, 1991.

SÃO PAULO. Secretaria de Estado da Saúde. Portaria GM/ MS n. 2.073 de 28 de setembro de 2004. Institui a Política Nacional de Atenção à Saúde Auditiva. 2004.

SILVA, M.J.P. O Papel da comunicação na humanização da atenção à saúde. In: Rev. bioét. (Impr.). v.10, 2002. p.73-78.

STARFIELD, B. Atenção Primária: Equilíbrio entre necessidades de saúde, serviços e tecnologias. Brasília: UNESCO/Ministério da Saúde, 2002.

TRIVIÑOS, A.N.S. Bases teórico-metodológicas da pesquisa qualitativa em ciências sociais: ideias gerais para a elaboração de um projeto de pesquisa. Faculdades Integradas Ritter dos Reis, 2001.

\title{
PUERICULTURA NA ATENÇÃO PRIMÁRIA EM SAÚDE: DESAFIOS NA ATUAÇÃO MULTIPROFISSIONAL
}

Janayna dos Santos Moura Hermínia Maria Sousa da Ponte

\author{
Introdução
}

A atenção básica caracteriza-se por um conjunto de ações de saúde, no âmbito individual e coletivo, que abrange a promoção e a proteção da saúde, a prevenção de agravos, o diagnóstico, o tratamento, a reabilitação, a redução de danos e a manutenção da saúde com o objetivo de desenvolver uma atenção integral que impacte na situação de saúde e autonomia das pessoas e nos determinantes e condicionantes de saúde das coletividades. É desenvolvida por meio do exercício de práticas de cuidado sob forma de trabalho em equipe, dirigidas à populações de territórios definidos, pelas quais assume a responsabilidade sanitária, considerando a dinamicidade existente no território em que vivem essas populações. (BRASIL. MINISTÉRIO DA SAÚDE. SECRETARIA DE GESTÃO DO TRABALHO E DA EDUCAÇÃO 
NA SAÚDE. DEPARTAMENTO DE GESTÃO DA EDUCAÇÃO EM SAÚDE, 2012)

Tem como foco de atuação as tecnologias de cuidado complexas e variadas que devem auxiliar no manejo das demandas e necessidades de saúde de maior frequência e relevância em seu território, observando critérios de risco, vulnerabilidade e resiliência. Entre os programas da atenção básica, a saúde da crianças, destaca-se pela prioridade nos indicadores epidemiológicos

A taxa de mortalidade infantil (referente às crianças menores de um ano) caiu muito nas últimas décadas no Brasil. Graças às ações de diminuição da pobreza, ampliação da cobertura da Estratégia Saúde da Família e a outros fatores, os óbitos infantis diminuíram de 47,1 a cada mil nascidos vivos, em 1990, para 15,6 em 2010. (IBGE, 2010) Entretanto, a meta de garantir a toda criança brasileira o direito à vida e à saúde ainda não foi alcançada, pois persistem desigualdades regionais e sociais inaceitáveis.

Com objetivo de intervir nessa realidade, a partir da mudança do modelo tecnoassistencial, representada pela ampliação do acesso aos serviços de saúde, pela desfragmentação da assistência e pela mudança na forma como o cuidado na saúde da criança vem sendo implementado, avançando na organização do processo de trabalho, questões tradicionais como o acompanhamento do crescimento e do desenvolvimento da criança e a supervisão das imunizações e até temas característicos da modernidade, como a alimentação saudável (tão essencial de ser trabalhada na situação atual de epidemia de obesidade infantil), a prevenção de acidentes e as medidas de prevenção e cuidado à criança em situação de violência etc. Nessa perspectiva, faz-se imprescindível uma abordagem multiprofissional para ampliar atuação na puericultura dentro da Estratégia em Saúde da Família.
Adotou-se nesse estudo a terminologia Puericultura, por ser uma prática assistencial abordada no Sistema Municipal de Saúde de Sobral - CE, que compreende ações de acompanhamento do crescimento e desenvolvimento infantil.

Apuericultura,áreadapediatriavoltadaprincipalmente para os aspectos de prevenção e de promoção da saúde, atua no sentido de manter a criança saudável para garantir seu pleno desenvolvimento, de modo que atinja a vida adulta sem influências desfavoráveis e problemas trazidos da infância. Suas ações priorizam a saúde em vez da doença. Seus objetivos básicos contemplam a promoção da saúde infantil, prevenção de doenças e educação da criança e de seus familiares, por meio de orientações antecipatórias aos riscos de agravos à saúde, podendo oferecer medidas preventivas mais eficazes. Para ser desenvolvida em sua plenitude, deve conhecer e compreender a criança em seu ambiente familiar e social, além de suas relações e interação com o contexto socioeconômico, histórico, político e cultural em que está inserida. Isto se torna fundamental pois as ações médicas, além de serem dirigidas à criança, refletem-se sobre o seu meio social, a começar pela família. Sem o envolvimento desta, as ações que visem às crianças não terão sucesso. (RICCO; ALMEIDA; DEL CIAMPO, 2005)

Os programas estruturados para oferecer Atenção Básica à saúde da criança têm como metas principais a promoção da saúde, prevenção de doenças, tratamento e reabilitação, e para serem efetivadas necessitam da participação do indivíduo e da sociedade, pressupondo a integração de diversas classes profissionais que atuam em equipe, devidamente calcados nos saberes interdisciplinares e apoiados pelos diferentes níveis de referência do sistema de saúde. 
Desta forma, o serviço de puericultura busca desenvolver ações de promoção à saúde, sendo considerado um dos pilares da saúde materno-infantil. Inúmeros recursos são fundamentados cientificamente nele, que serve de guia para alguns profissionais durante seus atendimentos.

Ao olhar para a atenção integral do cuidado na puericultura, numa abordagem da equipe multidisciplinar, essa atenção é incipiente, pois ainda percebe-se o predomínio da enfermagem e do médico, o que não significa dizer que outras categorias profissionais, que tiveram inserção recente a partir do Núcleo de Apoio à Saúde da Família (NASF), não possam estar envolvidas.

Partindo desse contexto e ancorados nos pressupostos do Sistema Único de Saúde (SUS) e da Atenção Primária à Saúde (APS), o trabalho multiprofissional é primordial para a equipe de Saúde da Família, em função, por exemplo, de tecnologias leves produzidas na convivência diária, condensadas pelas relações pessoais e profissionais de interação e subjetividade, o que possibilita um melhor acolhimento, vínculo, responsabilização e corresponsabilização, para acompanhar, encaminhar e dar resolubilidade às diversidades sociais e de saúde encontradas no território. (FERRI et al., 2007)

Neste sentido, a interdisciplinaridade no campo da Saúde Pública é algo indispensável diante das complexas necessidades expostas pela sociedade moderna e possibilita, como estratégia, redesenhar o processo de trabalho; promover a qualidade assistencial, reduzindo a duplicidade de ações entre os profissionais; e compreender, de forma compartilhada e integral, as necessidades para pleno desenvolvimento da criança durante a puericultura.

O cenário propício para efetivar a atuação multiprofissional tem sido estimulado pela ampliação das equipes do NASF e a inserção da Residência Multiprofissional em Saúde da Família (RMSF), que vem disparando outros processos no território para além dos procedimentos técnico-centrados.

Todavia, na prática, ainda há um distanciamento do que se almeja para o processo de cuidar multiprofissional na puericultura. Como Residente no programa da RMSF, acompanhando a dinâmica do cotidiano das equipes, percebemos a resistência de alguns profissionais para a realização de puericultura numa abordagem integrada, onde as práticas diferenciadas são isoladas, portanto, sendo incipiente a mensuração de impactos, em detrimento do modelo hegemônico das consultas individuais e pautadas em encaminhamentos da queixa-conduta.

Essa postura é fruto da formação tradicional em saúde, baseada na organização disciplinar e nas especialidades, que conduz à atuação fragmentada. Formam-se profissionais que dominam diversos tipos de tecnologias, porém, cada vez mais incapazes de lidar com a subjetividade e a diversidade moral, social e cultural das pessoas. Sendo também incapazes de lidar com questões complexas como a dificuldade de adesão ao tratamento, a autonomia no cuidado, a educação em saúde, o sofrimento da dor, o enfrentamento das perdas e da morte, o direito à saúde e à informação ou à necessidade de ampliar a autonomia das pessoas. (SANTOS; CUTOLO, 2004)

O presente estudo teve como objetivo discorrer sobre os desafios da atuação multiprofissional na puericultura, na Estratégia Saúde da Família, e conhecer os processos de educação permanente voltados ao atendimento nessa área. 


\section{Metodologia}

O estudo consistiu em uma pesquisa qualitativa. Segundo Minayo (2007, p.57), o método qualitativo é aplicável "ao estudo da história, das relações, das representações, das crenças, das percepções e das opiniões, produto das interpretações que os humanos fazem a respeito de como vivem, constroem seus artefatos e a si mesmos, sentem e pensam".

O estudo ocorreu no município de Sobral, que se distancia 223,3 Km da capital do Estado. Localizado na zona Centro-Oeste do Ceará, o município conta com uma área de $2.129,0 \mathrm{~km}^{2}$ e uma população estimada em 182.431 habitantes. (IBGE, 2013) O Centro de Saúde da Família desta pesquisa está localizado na Avenida da Universidade, na zona urbana de Sobral-CE, com 1.966 famílias assistidas, duas áreas descobertas, duas equipes de Saúde da Família e 11 Agentes Comunitários de Saúde. Além da assistência/do suporte do Núcleo de Apoio à Saúde da Família (NASF) e da Residência Multiprofissional em Saúde da Família (RMSF). (SOBRAL, 2013) O estudo foi realizado no período de agosto de 2013 a março de 2014.

Todos os profissionais de nível superior da Equipe de Saúde da Família, NASF e RMSF que atuam no local do estudo foram convidados a participar, somando-se um total de nove. A exclusão deu-se pelos que não aceitaram contribuir, além disso, adotamos o princípio da saturação de dados, ou seja, a suspensão de inclusão de novos participantes no estudo, devido à redundância e repetição das informações, caracterizada como regra metodológica da pesquisa qualitativa, entendendo que o critério da amostra não é numérico. (FONTANELLA; RICAS; TURATO 2008)

Participaram do estudo psicólogo, assistente social, nutricionista, terapeuta ocupacional, médica e enfermeiras dentre os profissionais de saúde. Desses, oito são do sexo feminino e um do sexo masculino, compreendidos na faixa etária de 23 a 52 anos.

Quadro 1 - Identificação dos participantes do estudo

\begin{tabular}{|l|c|}
\hline \multicolumn{2}{|c|}{ IDENTIFICAÇÃo DOS PARTICIPANTES DO ESTUDO } \\
\hline Profissionais & Siglas \\
\hline Psicólogo do NASF & P1 \\
\hline Assistente social do NASF & A1 \\
\hline Nutricionista do NASF & N1 \\
\hline Terapeuta Ocupacional da RMSF & T1 \\
\hline Enfermeira da assistência & E1 \\
\hline Enfermeira da assistência & E2 \\
\hline Enfermeira da assistência & E3 \\
\hline Enfermeira da RMSF & E4 \\
\hline Médica pediatra do CSF & M1 \\
\hline
\end{tabular}

Fonte: Elaborada pela autora, 2012.

Foram realizadas entrevistas, previamente marcadas, conforme a disponibilidade dos participantes, e conduzidas pela pesquisadora principal, de forma individualizada, no Centro de Saúde da Família (CSF). A técnica de coleta de entrevista escolhida foi a semiestruturada, gravada com permissão prévia dos participantes. Segundo Minayo (2008), a entrevista semiestruturada é caracterizada como a "técnica que combina perguntas fechadas (ou estruturadas) e abertas, onde o entrevistado tem a possibilidade de discorrer sobre o tema proposto, sem respostas ou condições prefixadas". 
Na busca por atingir os significados manifestos e latentes no material qualitativo têm sido desenvolvidas várias técnicas, dentre elas, a análise temática, que foi utilizada nesta pesquisa. (BONILHA, 2012)

A categorização empírica resultou nos seguintes temas centrais: 1) Necessidade de compartilhamento na puericultura; 2) Profissionais atuantes na puericultura; 3) Educação permanente como uma estratégia para organização do processo de trabalho na puericultura. Tais temas foram subdivididos em dimensões, resultando numa rede interpretativa do estudo sistematizada no quadro abaixo:

\section{Quadro 2-Rede Interpretativa do estudo}

\begin{tabular}{|c|c|c|c|}
\hline \multicolumn{4}{|c|}{ REDE INTERPRETATIVA DO ESTUDO } \\
\hline \multirow{2}{*}{$\begin{array}{l}\text { Temas } \\
\text { Necessidade de } \\
\text { compartilhamento } \\
\text { na puericultura }\end{array}$} & \multicolumn{3}{|l|}{ Dimensões } \\
\hline & $\begin{array}{l}\text { Cuidado } \\
\text { integral na } \\
\text { puericultura }\end{array}$ & $\begin{array}{l}\text { Contribuição } \\
\text { do fazer dos } \\
\text { profissionais } \\
\text { na } \\
\text { puericultura }\end{array}$ & $* * * * *$ \\
\hline $\begin{array}{l}\text { Profissionais } \\
\text { atuantes na } \\
\text { puericultura }\end{array}$ & $\begin{array}{l}\text { Olhar } \\
\text { direcionado } \\
\text { ao modelo } \\
\text { biomédico }\end{array}$ & $* * * * *$ & $* * * * *$ \\
\hline $\begin{array}{l}\text { Educação } \\
\text { permanente como } \\
\text { uma estratégia } \\
\text { para organização } \\
\text { do processo } \\
\text { de trabalho na } \\
\text { puericultura }\end{array}$ & $\begin{array}{l}\text { Necessidade } \\
\text { de fazer } \\
\text { educação } \\
\text { permanente } \\
\text { voltada à } \\
\text { puericultura }\end{array}$ & $\begin{array}{l}\text { Dinâmica do } \\
\text { território na } \\
\text { Estratégia } \\
\text { Saúde da } \\
\text { Família (ESF) }\end{array}$ & $\begin{array}{l}\text { Disponibilidade } \\
\text { dos } \\
\text { profissionais } \\
\text { na Estratégia } \\
\text { Saúde da } \\
\text { Família (ESF) }\end{array}$ \\
\hline
\end{tabular}

Fonte: Elaborado pela autora, 2012.
Desta forma, realizamos a transcrição das falas e retiramos, por meio de recortes, o produto final, sendo considerados trechos relevantes para esta pesquisa. A categorização empírica foi agrupada em forma temática e os subprodutos em dimensões.

\section{Resultados e discussão}

Necessidades de compartilhamento entre os profissionais na puericultura

O compartilhamento, no programa de puericultura, deve ser considerado fundamental para a efetivação dos pressupostos estabelecidos pelo Sistema único de Saúde e pela Política de Atenção à Saúde da Criança. É urgente que os serviços públicos de saúde estabeleçam práticas de trabalho que considerem as reais necessidades dos sujeitos, com atendimento de forma mais humanizada, resguardando os princípios de equidade e integralidade.

Há relação dialética entre os enfoques individuais e coletivos na construção do cuidado integral. Para Sílvia e Sene (2008), a integralidade é constituída no convívio do trabalho, por meio de relações que se vinculam, numa construção ampliada de saúde, respeitando os saberes multi e transdisciplinares.

Nas discussões dos profissionais sobre atuação interdisciplinar, em todas as falas é notória a necessidade de compartilhamento na puericultura e um cuidado integral, como identificamos nos depoimentos abaixo:

Percebo uma assistência mais completa, mais integral à criança, com a soma dos saberes das categorias que prestam 
esse cuidado oferecendo à criança uma assistência e cuidado integral. (E4)

É de suma importância a presença dos demais profissionais, porque observa aquele paciente de uma forma integral. (A1)

É mais comum a presença do enfermeiro, mas participar da puericultura seria importantíssimo para as outras categorias. (N1)

Corroborando com essa discussão, Matos, Pires e Gelbcke (2012) indicam que no Brasil, nos últimos 30 anos, a interdisciplinaridade consegue ser visualizada como caminho para redução da fragmentação do cuidado em saúde e potencializada como uma forma de dar assistência na perspectiva da integralidade. Como podemos visualizar na fala de um dos profissionais entrevistados:

Uma puericultura para ser completa é necessária essa atuação interdisciplinar. (T1)

A integração de outros profissionais na ESF tem como objetivo enfrentar com maior resolubilidade os problemas identificados, de forma individualizada ou coletivamente, analisando as formas biológicas ou socioculturais, na busca de alcançar a integralidade, base da atual concepção de saúde. (HENRIQUE, 2006)

Numa primeira dimensão da integralidade, para os profissionais, isso significa incluir no seu cotidiano de trabalho rotinas ou processos de busca sistemática daquelas necessidades mais silenciosas, e adotar processos coletivos de trabalho. Não se trata, portanto, de simplesmente desenvolver protocolos ou rotinas capazes de identificar e oferecer ações preventivas.
Contribuição do fazer dos profissionais na puericultura

Vale destacar que, para Campos e Domittis (2007), os profissionais da ESF que atuam de forma interdisciplinar ou transdisciplinar (onde "trans" significa o aumento do grau de discussões, da troca de conhecimentos, de sentimentos e de corresponsabilidades entre participantes da equipe) têm poder de decisão na organização, ou seja, no que diz respeito ao processo de trabalho.

Com isso, podemos considerar que os profissionais reconhecem a atuação interdisciplinar e valorizam a troca de conhecimento e experiência, o que podemos comprovar abaixo:

Havendo essa troca cada profissional aprende até um pouco do fazer do outro. (T1)

É a troca de experiência entre as várias áreas, a discussão da visão diferenciada de cada coisa e de cada profissional. (M1)

Os profissionais presentes contribuem com seu saber específico. (E4)

Se dá pela contribuição do fazer de cada profissional de cada categoria. (A1)

Outras categorias, de acordo com sua profissão, fazem suas considerações e encaminhamentos. (E3)

A atuação de forma integrada propicia a construção de Projeto Terapêutico Singular, pautado no encontro das diversas áreas de atuação. É atribuição dos Profissionais do NASF participar da construção de planos e abordagens terapêuticas em comum com os profissionais das equipes de Saúde da Família, de acordo com as necessidades evidenciadas pelas equipes. (BRASIL. MINISTÉRIO DASAÚDE. 
SECRETARIA DE ATENÇÃO À SAÚDE. DEPARTAMENTO DE ATENÇÃO BÁSICA, 2012)

Sendo assim, cada profissional tem um olhar diferenciado, que estáatreladoà sua formação e qualificação. Através dessa/De acordo com essa visão, existem várias potencialidades, que merecem ser compartilhadas.

\section{Profissionais atuantes na puericultura}

As ações desenvolvidas durante a puericultura são: avaliar e realizar exames físicos na criança; analisar os riscos para o seu crescimento e desenvolvimento; monitorar e anotar na caderneta de vacinação o peso, estatura e informações sobre a vacinação; incentivar o Aleitamento Materno Exclusivo (AME) até os seis meses; informar a necessidade da alimentação complementar após os seis meses; orientar sobre prevenção de acidentes doméstico e eventuais; observar o desenvolvimento neuropsicomotor; esclarecer dúvidas e dificuldades da mãe e de outros membros da família que participam das consultas. (VIEIRA, et al., 2012)

Historicamente, a assistência à saúde à criança, durante a puericultura, era centrada no fazer médico e da enfermagem, afinal foram as primeiras categorias profissionais na inserção da ESF no Brasil. Como demonstra a fala do psicólogo.

A enfermagem é que trabalha diretamente com a puericultura, os médicos por atenderem em situações de gravidade as crianças e as puérperas, a nutrição a categoria mais inserida pela questão do aleitamento materno, substituição da alimentação da criança e da puérpera, o psicólogo só é chamado quando a criança apresenta hiperativismo. (P1)
O enfermeiro e o nutricionista, os profissionais que mais atuam na saúde da criança. (E1)

A inserção de novas categorias profissionais na ESF deve catalisar transformação no processo de cuidado com a clínica ampliada, principalmente por meio das tecnologias leves, através de educação em saúde coletiva, educação permanente e apoio matricial. Rompendo com a centralidade de algumas categorias.

\section{Olhar direcionado ao modelo biomédico}

O apoio matricial é uma das estratégias utilizadas pela equipe do NASF, onde uma especialidade obtém o conhecimento de núcleo com formas distintas dos profissionais de referência, com capacidade de agregar conhecimentos e experiências práticas, objetivando a resolutividadedosproblemasdesaúdedaequiperesponsável pelo caso. Sendo ativadores no compartilhamento de profissionais de referência e apoiadores. $\mathrm{Na}$ atenção ao cuidado, na infância, os apoiados, buscam formas de cuidado apoiado às equipes, exemplo: observar atraso no desenvolvimento psicomotor e cognitivo, promover educações em saúde nas ações de puericultura e buscar articulação intersetorial para fortalecer as ações dentro do território. (GOMES; BRITO, 2013)

Neste sentido, convém destacar que para Campos e Domittis (2007), o trabalho multidisciplinar depende inteiramente da predisposição subjetiva, para receber e fazer colocações críticas, e para pactuar casos compartilhados. Do contrário, os indivíduos tendem a criar certo receio, gerando uma identidade reativa que os leva a não confiar no outro e impor uma barreira de defesa, ficando até mesmo paranoicos com medo da concorrência. Com isso, 
o profissional acaba fechado em seu próprio núcleo de especialidade, o que dificulta a interação interdisciplinar. Tal como expressa a entrevistada a seguir:

O médico puxa pra si só, não possibilita atuação interdisciplinar, o que é de suma importância para que se possa fechar um diagnóstico preciso dessa criança, e muitas vezes não possibilita vias de diálogo para os demais membros da equipe contribuir, querendo deter todo conhecimento e evitando concorrência. (N1)

A partir desta afirmação, é necessário focar nos aspectos mais relevantes relacionados às peculiaridades da atuação desses profissionais, uma vez que a construção desse cuidado na infância não é específico de uma área de conhecimento. Ela pode, também, ter um olhar com foco no desenvolvimento nutricional, psicológico, assistencial e cognitivo que promova o crescimento e desenvolvimento infantil, resultante de processos de trabalho unificados.

A postura biomédica não é específica do profissional médico, ela é percebida na atuação dos demais profissionais da atenção primária, que tendem a trabalhar com o referencial sobre a dinâmica do processo saúde e doença. Compactuando com e reproduzindo a racionalidade do modelo biomédico, são levados a um comportamento limitado. (LUZ, 2004) Como é expresso na fala do psicólogo:

Os profissionais não conseguem observar minha contribuição na puericultura, somente quando existem casos específicos para um compartilhamento (Ex: crianças hiperativas e depressão pós-parto). (P1)

É comum observarmos alguns profissionais atrelados à avaliação clínica pautada em uma sintomatologia do sujeito o que, obviamente, não pode ser negligenciado, contudo, os profissionais devem buscar outras formas de fazer cuidado, sendo criativos no processo de trabalho vivo em ato e não meramente centrados nos protocolos assistenciais e metas.

\section{A educação permanente como uma estratégia para organização do processo de trabalho na puericultura}

A Educação Permanente em Saúde é considerada uma aprendizagem no trabalho, onde o aprender e o ensinar incorporam-se ao cotidiano das organizações. Baseia-se na aprendizagem significativa e na possibilidade de transformar as práticas profissionais, sendo formulada a partir dos problemas enfrentados na realidade e levando em consideração os conhecimentos e as experiências que as pessoas já têm. Esses momentos acontecem em espaços de reuniões de planejamento, estando neles incluídas: discussões de casos, definições de contratos e objetivos, encaminhamentos, casos que merecem ser compartilhados, avaliações e as formas de resolutividade de problemas. (BRASIL, 2009)

Partindo deste pressuposto, os profissionais deste estudo apresentam as seguintes discussões:

Nesses seis meses que estou no NASF nunca participei de nenhuma EP sobre puericultura, e sinto extrema necessidade de fazer. (P1)

Está faltado EP até mesmo para estar puxando a participação de outros profissionais nesse momento da puericultura. (A1)

Um dos momentos oportunos para discutir assistência multi na puericultura seria nas 
rodas dos CSF nas quintas-feiras onde toda a equipe está reunida, e onde deve ser o repensar o processo de trabalho. (N1).

A realização desta pesquisa permitiu identificar as fragilidades do Sistema Único de Saúde local, onde os profissionais identificam a necessidade de educação permanente direcionada à puericultura, com foco na atuação interdisciplinar, formação que pode ser disparada/ encaminhada no cotidiano do serviço, potencializados os espaços coletivos em que a equipe já se reúne.

\section{Processo de trabalho na Estratégia Saúde da Família}

Há obstáculos na própria maneira como as organizações vêm se estruturando, que conspiram contra esse modo interdisciplinar e dialógico de operar/agir. Esses obstáculos precisam ser conhecidos, analisados e, quando possível, removidos ou enfraquecidos para que seja possível trabalhar com base em equipe interdisciplinar e sistemas de cogestão. (CAMPOS; DOMITTI, 2007) Dentre esses obstáculos, podemos ter algumas representações nos discursos dos participantes do estudo, conforme abaixo:

Cobranças de protocolos e demanda elevada do serviço que nos tira toda a criatividade e dinamicidade para repensar o processo de trabalho. (M1)

Não poder trocar experiências com outros profissionais em decorrência da demanda do território, é uma queixa constante dos profissionais o que nos leva a fazer repetido. (P1)

Minha categoria e as demais tenta fazer essa atuação junto à categoria da medicina, mas se torna algo difícil pela resistência e pela demanda do território. (T1)
Nos depoimentos ficaram marcantes os desafios operacionais de uma assistência de puericultura multiprofissional, prejudicada pelas cobranças de protocolos, demandas elevadas e a resistência de algumas categorias profissionais. Repensar a práxis assistencial demanda tempo, congruência de agendas entre os profissionais e desprendimento de postura para romper com a postura tecnicista e repetitiva, desprovida de criatividade.

Identificar e compor uma equipe de trabalho que favoreça assistência sanitária para a comunidade, nos princípios da integralidade, é um desafio presente na formação de profissionais que a residência multiprofissional busca resgatar, e como não está pronto é um exercício da prática cotidiana. (COTTA, 2006)

Esse modelo reverbera nas práticas hegemônicas de puericultura, segundo constatamos na fala dos profissionais.

Geralmente as puericulturas na interdisciplinaridade, a médica não é incluída geralmente ela sempre faz sua puericultura sozinha. (T1)

Nem sempre, no horário da agenda da puericultura os profissionais RMSF e NASF estão disponíveis para acontecer essa troca de saberes entres os profissionais. (E1)

A dificuldade de conseguir horários comuns entre os diversos profissionais, e também, às vezes, os profissionais não se sentem confortáveis com a atuação interdisciplinar. (E4)

Tempo insuficiente dos profissionais para atuarem em todos os atendimentos. (E2)

Um ponto limite presente nesse estudo versou sobre a incompatibilidade de agenda e não priorização de um 
atendimento integrado. Portanto, deve-se reorganizar a agenda com foco na atuação integral à saúde da criança, sendo imprescindível tanto a atuação do NASF como da RMSF.

Neste sentido, a atuação dos profissionais é o que garante a efetivação do processo de trabalho interdisciplinar e para isso, é fundamental que o trabalhador da saúde tenha transparência, bom humor, que saiba ouvir, que seja alegre, que tenha confiança, que seja flexível, tenha responsabilidade, diplomacia, organização e tolerância. (MADEIRA, 2009)

Segundo Merhy e Cecílio (2003), as organizações em saúde compreendem o cuidado em geral como uma necessidade multidisciplinar, que depende da conjugação do trabalho de vários profissionais. Ou seja, são denominações interpessoais de valores e práticas, onde deve existir a colaboração entre o profissional e o trabalhador com o operador de tecnologias leves de saúde, para que o cuidado aconteça.

\section{Considerações finais}

A puericultura é um dispositivo assistencial que deve ser realizado de forma interdisciplinar, promovendo um cuidado integral no desenvolvimento e crescimento na infância. Embora essa conduta profissional na atenção primária aconteça no município da pesquisa, ainda não é uma prática hegemônica nos demais serviços. Devido a essa prática incipiente, os profissionais pesquisados revelaram algumas dificuldades de operacionalização neste sentido, sendo que as tecnologias leves são importantes ferramentas que devem ser inseridas no processo de trabalho das equipes.
Outro aspecto relevante desta pesquisa referese à percepção dos profissionais entrevistados sobre a prática interdisciplinar como norteadora do processo de trabalho, e também, como espaço para discussões, troca de informações e saberes. A pesquisa ainda despertou reflexões sobre o trabalho em saúde, na atenção à saúde integral, no sentido de que possa contribuir com a qualidade de vida da comunidade. Necessita esse trabalho, contudo, de um melhor aprofundamento na perspectiva dos princípios norteadores da APS.

Atuando como residente na atenção primária, nos foi possível observar a realização da interdisciplinaridade somente quando há um desejo por parte de cada profissional de aderir e de se engajar na construção da prática coletiva. A postura interdisciplinar exige trocas entre os profissionais e a abertura para questionar e ser questionado.

O estudo permitiu identificar e descrever como a equipe estabelece relações interdisciplinares através da puericultura. Sendo assim, a equipe almeja uma política que inclua a qualificação dos profissionais de saúde que atuam no respectivo campo do estudo, por meio da educação permanente, aliados ao esforço conjunto de gestores e profissionais e uma visão integrada da saúde.

\section{Referências}

ACIOLI. S. A prática educativa como expressão do cuidado em saúde. In: Revista Brasileira de Enfermagem. v.61, n.1, 2008.

BARROS, F.S.; PINHEIRO, R. Notas teóricas sobre a noção de competência: discutindo cuidado e humanização na saúde. In PINHEIRO, R.; BARROS, M.E.B.; 
BRASIL. Ministério da Saúde. Secretaria de Gestão do Trabalho e da Educação na Saúde. Departamento de Gestão da Educação em Saúde. Política Nacional de Educação Permanente em Saúde. Brasília: Ministério da Saúde, 2009.

BRASIL. Ministério da Saúde. Secretaria de Atenção à Saúde. Departamento de Atenção Básica. Política Nacional de Atenção Básica. Brasília:Ministério da Saúde, 2012.

BONILHA, A.L.L. Reflexões sobre análise em pesquisa qualitativa [editorial]. In: Revista Gaúcha de Enfermagem. v.33, n.1, 2012.

BOSI, M.L.M. Pesquisa qualitativa em saúde coletiva: panorama e desafios. In: Ciência \& Saúde Coletiva. v.17, n.3, 2012.

CAMPOS G.W.S.; DOMITTI, A. C. Apoio matricial e equipe de referência: uma metodologia para gestão do trabalho interdisciplinar em saúde. In: Saúde Pública, Rio de Janeiro, v.23, n.2, 2007.

COTTA et al. Organização do trabalho e perfil dos profissionais do programa de Saúde da Família: um desafio na reestruturação da atenção básica em saúde. In: Epidemiologia. Serviço. Saúde. Viçosa-MG, v.15, n.3, p.718, 2006.

FIGUEIREDO, G.L.A.; MELO, D. F.A prática de enfermagem na atenção à saúde da criança em unidade básica de saúde. In: Revista Latino-am Enfermagem. Ribeirão Preto - SP, v.11, n.4, p.544-51, 2003.

FERRI, S.M.N. et al. As tecnologias leves como geradoras de satisfação em usuários de uma unidade de saúde da família. Interface, Botucatu. v.11, n.23, 2007.
FONTANELLA, B.J.B.; RICAS, J.; URATO, E.R. Amostragem por saturação em pesquisas qualitativas em saúde: contribuições teóricas. In: Caderno de Saúde Pública. v.24, n.1, 2008.

GOMES, R. Análise e interpretação de dados de pesquisa qualitativa. In: MINAYO, M. C.S.; DESLANDES, S.F.; GOMES, R. Pesquisa Social: teoria, método e criatividade. 26ed. Petrópolis (RJ): Vozes, 2007.

GOMES, J.A; BRITO, C.M.D. Apoio matricial e terapia ocupacional: uma experiência de abordagem na saúde da criança. In: Rev Ter Ocup Univ São Paulo, 2013, jan./abr. v.24, n.1, p.81-6.

HENRIQUE, F. Atenção Primaria em Saúde: Histórias, Contexto Conceitos e Tendências no Brasil e em Santa Catarina. In: CUTOLO, L.R.A (Org). Manual Terapêutica Assistência à Família. Florianópolis: Associação Catarinense de Medicina, 2006.

IBGE. Instituto Brasileiro de Geografia e Estatística.Contagem da População 2009. Disponível em: <http://www.ibge.gov. br/home/estatistica/populacao/contagem2009/default. shtm>. Acesso em: 4 mai 2013.

IBGE. Instituto Brasileiro de Geografia e Estatística. Censo demográfico brasileiro 2010. Disponível em: <http://www. ibge.gov.br/home/presidencia/noticias/imprensa/ppts/00 $000008473104122012315727483985 . p d f$ _. Acesso em: 10 ago 2014.

LUZ, M.T. Natural, racional, social: razão médica e racionalidade científica moderna. São Paulo: Editora Hucitec; 2004. 
MADEIRA, K.H. Práticas do trabalho interdisciplinar na saúde da família: um estudo de caso. Dissertação (Mestrado). Universidade do Vale de Itajaí, Centro de Ciências da Saúde, Mestrado em Saúde e Gestão do Trabalho, Itajaí, 2009.

MATOS, E.; PIRES D.E.P; GELBCKE, F.L. Implicações da interdisciplinaridade na organização do trabalho da enfermagem: estudo em equipe de cuidados paliativos. In: Rev. Eletr. Enf.v.12, n.12, 2012.

MERHY, E.E.; CECÍLIO, L.C.O. A integralidade do cuidado como eixo da gestão hospitalar. Campinas: Unicamp, 2003.

MINAYO, M.C.S. O Desafio do Conhecimento: pesquisa qualitativa em saúde. 11 ed. São Paulo: HUCITEC, 2008.

RICCO, R.G; ALMEIDA, C.A.N; DEL CIAMPO, L.A. Puericultura: temas de pediatria 80. São Paulo: Nestlé; 2005.

SILVIA, K.L.; SENA, R.R. Integralidade do cuidado na saúde: Indicações a partir da formação do enfermeiro. In: Revista Escola de Enfermagem. São Paulo, v.42, n.1, 2008.

SOBRAL. Ministério da Saúde. Sistema de Informação da Atenção Básica - SIAB, 2013.

SOITO, R.X.D.E.S. Política de Saúde: Princípios, Diretrizes e Estratégias para a estruturação de um Sistema Único de Saúde. In: OHARA, E.C.C.; SAITO, R.X.D.E.S. (Orgs). Saúde da Família: Considerações teóricas e aplicabilidade. São Paulo: Martinari, 2008.

SANTOS, M.A.M; CUTOLO, L.R.A. A interdisciplinaridade e o trabalho em equipe no Programa de Saúde da Família. In: Arquivos Catarinenses de Medicina, v.33, n.32, 2004.

VIEIRA, V.C.L. et al. Puericultura na Atenção Primária à Saúde: Atuação do Enfermeiro. In: Cogitare Enferm. v.17, n.1, 2012.

\section{SAÚDE E ENVELHECIMENTO: A PERSPECTIVA DE IDOSOS PARTICIPANTES DE UM GRUPO DE CONVIVÊNCIA DA ESTRATÉGIA SAÚDE DA FAMÍLA}

\author{
Elyudienne Andressa Silva Alves \\ Diana Cris Macedo Rodrigues \\ Carla Silvino de Oliveira
} Israel Rocha Brandão

\section{Introdução}

O presente capítulo deriva de um Trabalho de Conclusão de Curso de Residência Multiprofissional em Saúde da Família, da Universidade Estadual Vale do Acaraú (UVA) em parceria com a Escola de Formação em Saúde da Família Visconde de Sabóia em Sobral - CE. O estudo buscou, entre outros objetivos, compreender concepções de saúde e envelhecimento de idosos participantes de um grupo de convivência de um município no interior do Ceará, sendo este o recorte eleito para a construção dessa publicação.

A opção por tal objeto de estudo resulta da assunção da polissemia envolvida nos conceitos de saúde e envelhecimento, derivada das singularidades e 
subjetividades dos indivíduos e suas experiências. Tais aspectos foram intensamente identificados nos relatos dos idosos, durante a atuação da pesquisadora principal como nutricionista na Estratégia Saúde da Família (ESF), e motivaram o desenvolvimento do estudo, que teve entre seus questionamentos iniciais os seguintes: como o idoso percebe o processo de envelhecimento? Como a saúde é definida/ avaliada por ele?

Nessa perspectiva, faz-se necessário, em um primeiro momento, imergir nas definições e considerações presentes na literatura acerca do envelhecimento para subsidiar a discussão empreendida a seguir.

No Brasil, o Ministério da Saúde define a idade cronológica igual ou superior a 60 anos para que o indivíduo seja considerado idoso. (BRASIL. MINISTÉRIO DA SAÚDE, 2006) No entanto, em diferentes contextos de países ditos desenvolvidos e em desenvolvimento, a idade cronológica não é um marcador preciso para as mudanças que acompanham o envelhecimento, já que existem variações significativas relacionadas ao estado de saúde, participação e níveis de independência entre pessoas mais velhas que possuem a mesma idade. (OMS, 2005)

Em consonância com tal afirmativa, Fazzio (2012) argumenta que o envelhecimento pode ser entendido como um processo individual, cultural e social influenciado pela interdependência de vidas, o qual envolve ganhos e perdas, não podendo ser avaliado apenas pela idade, mas sim a partir de uma visão biológica, psicológica e social.

No entanto, observa-se com frequência, nos estudos sobre o processo de envelhecimento, mais referências aos aspectos negativos tais como perdas e doenças, do que comentários sobre os ganhos associados à velhice como sabedoria, experiência e habilidade nos relacionamentos sociais. (FAZZIO, 2012)
Moreira (2012) em seu estudo, o qual pretendia realizar a reflexão teórica sobre a mudança na percepção do processo de envelhecimento, afirma que a cultura contemporânea expressa um horror à velhice, à medida que celebra o corpo jovem. Nesta concepção, a velhice é vinculada ao declínio e contrapõe-se ao desenvolvimento. Por outro lado, segundo o referido autor, os preconceitos científicos em relação ao envelhecimento começam a ceder e abrir espaços para o avanço das pesquisas.

Destaca-se, também, o expressivo crescimento da população idosa nas últimas quatro décadas. Tal fenômeno ocorreu inicialmente em países desenvolvidos e, mais recentemente, nos países em desenvolvimento, como o Brasil. O país tem revelado crescimento exponencial dessa população, cuja projeção para o ano de 2025 prevê que o número de indivíduos com idade igual ou superior a 60 anos será de 32 milhões. (FERREIRA et al., 2010; GUERRA; CALDAS, 2010; VERAS, 2003)

Nos países desenvolvidos, esse processo de transição demográfica deu-se de forma gradual, ao longo de mais de um século, acompanhado de um progresso socioeconômico favorável e da consequente melhoria das condições de vida da população, que contou com um amplo sistema de proteção social. Ao contrário, nos países em desenvolvimento, o processo de envelhecimento vem ocorrendo rapidamente, num ambiente socioeconômico pouco favorável à expansão de um sistema de proteção social para todos os grupos etários. (KRELING, 2010)

É válido ressaltar ainda, o fenômeno da transição epidemiológica, o qual identifica importantes alterações nos padrões de saúde/doença das populações, como os padrões de elevada prevalência de doenças infecciosas associadas à desnutrição, fome e condições sanitárias inadequadas para elevada prevalência de Doenças Crônicas 
Não Transmissíveis (DCNT) ${ }^{1}$ associadas a estilos de vida urbano-industriais. (MONDINI; GIMENO, 2011)

De modo concomitante ou posterior aos processos de transição demográfica e epidemiológica, a transição nutricional vem se desenvolvendo no Brasil. Segundo Wanderley e Ferreira (2010), essa dinâmica caracteriza-se pela modificação nos padrões de distribuição dos agravos nutricionais de uma população em determinado período de tempo. Configura-se por uma redução na prevalência das doenças associadas ao subdesenvolvimento concomitante ao aumento daquelas doenças vinculadas à modernidade, tendo, em geral, uma coexistência desses agravos, destacando-se neste cenário as DCNT. Assim, conforme os indivíduos envelhecem, essas doenças crônicas passam a representar as principais causas de morbidade, incapacidade e mortalidade em todas as regiões do mundo. (OMS, 2005)

Nesse sentido, o fenômeno do envelhecimento populacional tornou-se uma questão de importante relevância para as políticas sociais e de saúde, uma vez que os idosos representam um grupo bastante diferenciado entre si e em relação aos demais grupos etários, derivando desafios singulares a serem superados pelas estratégias governamentais e da sociedade civil. (FERREIRA et al., 2010; GUERRA e CALDAS, 2010; VERAS, 2003)

Dentre as questões de maior relevância dessa transição demográfica, estão as do âmbito da previdência social e da saúde devido ao significativo impacto nas políticas econômicas e socioassistenciais do país, as quais precisam agregar a todo o processo de promoção da qualidade de

\footnotetext{
1 "A exemplo das DCNT, estão as doenças cardiovasculares, diabetes mellitus, e alguns tipos de câncer, que inicialmente se restringiam a populações urbanas de alta renda, porém se disseminou para todos os setores da sociedade". (MONDINI; GIMENO, 2011, p.563)
}

vida, ações integradas para a melhoria dos aspectos ligados à moradia, à saúde, à alimentação, à educação e à igualdade de oportunidades. (ALENCAR et al., 2008)

Portanto, é essencial que os serviços que prestam assistência a idosos respondam à necessidades específicas e distingam-se pela natureza da intensidade dos serviços que ofereçam, uma vez que os padrões de morbimortalidade (problemas crônicos) da população idosa diferem radicalmente dos observados no restante da população, ocasionando necessidades permanentes de atenção à saúde. (BRASIL, MINISTÉRIO DA SAÚDE, 2006; CAMARANO; PASINATO, 2005; WONG; CARVALHO, 2006)

Com o fenômeno da transição demográfica, as políticas públicas deverão responder às necessidades desse grupo etário, por meio do desenvolvimento de políticas de saúde que privilegiem a promoção da saúde e da qualidade de vida desses indivíduos. Entre as prioridades está, sem dúvida, a formação de recursos humanos para serviços geriátricos e gerontológicos, desde a atenção primária à saúde até outros níveis de atenção. (WONG; CARVALHO, 2006)

Tais particularidades do envelhecimento evidenciam a necessidade de promoção da saúde com vistas ao envelhecimento ativo, resultando em desafios para as autoridades sanitárias, especialmente no que tange à implantação de novos modelos e métodos de planejamento, gerência e prestação de cuidados. (CAMARANO; PASINATO, 2005)

Pode contribuir para esse processo, o atendimento primário de saúde, por meio da Atenção Básica à Saúde (ABS), a qual, orientada pelos princípios de universalidade, integralidade, equidade, descentralização e controle social configura-se como estratégia de organização do sistema de saúde no âmbito individual e coletivo. Insere-se neste 
nível de atenção a Estratégia Saúde da Família (ESF), a qual propõe a prestação de uma atenção à saúde integral e contínua, possibilitando a melhoria das condições de vida das famílias. A ESF coloca a necessidade de uma atenção especial aos idosos. Essa atenção pode efetivar-se através de medidas promocionais de proteção específica, da identificação precoce dos agravos de saúde mais frequentes e sua intervenção, bem como por medidas de reabilitação voltadas para evitar a sua separação do convívio familiar e social, com possibilidade de melhor qualidade de vida. (CAMARANO; PASINATO, 2005; FACCHINI et al., 2008)

Além disso, a ESF incorporou novos elementos para a reorientação do processo de trabalho em saúde, os quais demandam profissionais capazes de operar as inovadoras propostas. Nesse novo modo de pensar a organização do trabalho em saúde, destacam- se as tecnologias leves em saúde que estão intrinsecamente ligadas ao produto das relações dialógicas entre o sujeito trabalhador e o sujeito usuário. Nesta proposta são evidenciadas as relações dependentes do contato direto entre sujeitos, a produção do vínculo, a autonomização e a gestão compartilhada de processos de trabalho como orientadoras das práticas em serviços de saúde. (PESSANHA; CUNHA, 2009)

Nesse sentido, evidenciar perspectivas e representações de quem vivencia o fenômeno do envelhecimento e a relação deste com a dinâmica do processo saúde-doença, torna-se imprescindível para a elaboração de estratégias mais coerentes com as necessidades peculiares desse público e com os princípios e diretrizes do Sistema Único de Saúde (SUS).

\section{Metodologia}

Trata-se de uma investigação de natureza qualitativa. Segundo Bosi (2012), a pesquisa qualitativa é caracterizada por objetos que exigem respostas não traduzíveis em números, haja vista tomar como material a linguagem em suas várias formas de expressão. Para Minayo (2004), esse tipo de pesquisa é capaz de incorporar a questão do significado e da intencionalidade como inerentes aos atos, às relações e às estruturas sociais, sendo essas últimas tomadas tanto no seu advento quanto na sua transformação, como construções humanas significativas.

O cenário do estudo consiste em um grupo de idosos de um território de saúde localizado em Sobral, Ceará. De acordo com dados do Sistema de Informação da Atenção Básica - SIAB ${ }^{2}$ (2014), o município possui cerca de 21.868 idosos, o que representa $10,3 \%$ da população. No território escolhido como cenário da pesquisa há cerca de 7.096 pessoas constituindo 1.873 famílias, sendo 613 idosos. (SIAB, 2014)

O grupo de convivência selecionado para a pesquisa realiza encontros semanais, os quais ocorrem alternadamente no auditório do Centro de Saúde da Família (CSF) de referência e no Centro de Referência de Assistência Social (CRAS) do território. Tal estratégia surgiu em 2005, por iniciativa dos profissionais do CSF, objetivando proporcionar um espaço de socialização e promoção da saúde dos idosos residentes na área adscrita, focando especialmente aqueles com hipertensão arterial sistêmica e diabetes mellitus. Apresenta como principais cuidadores

$2 \underline{\text { SIAB }}$ é um sistema (software), desenvolvido pelo DATASUS em 1998, cujo objetivo centra-se em agregar, armazenar e processar as informações relacionadas à Atenção Básica em Saúde (ABS), usando como estratégia central a Estratégia de Saúde da Família (ESF). Os dados acima foram coletados em 17 de fevereiro de 2014. 
e apoiadores os Agentes Comunitários de Saúde (ACS), os profissionais da Residência Multiprofissional em Saúde da Família (RMSF) e do Núcleo de Apoio à Saúde da Família (NASF), articulados com o CRAS. Atualmente, o grupo é composto por uma média de trinta participantes, com predominância do sexo feminino.

O território de saúde foi intencionalmente escolhido por possuir em sua área um grupo de idosos que funcionava há um período de tempo mais longo, bem como por haver um maior vínculo com os profissionais atuantes nesse território, facilitando assim, o acesso para abordagem inicial nesse espaço. Foram convidados para participar da pesquisa os usuários que frequentavam esse grupo. Os critérios de inclusão foram: participantes do grupo com idade igual ou maior que 60 anos. Os critérios de exclusão foram: menores de 60 anos ou que não aceitaram participar da pesquisa. Não houve restrição quanto ao sexo nem etnia.

Quanto ao número de participantes da pesquisa, foram sete idosos, total delimitado segundo o critério metodológico da saturação teórica, ou seja, suspensão de inclusão de novos participantes no estudo, devido à redundância e repetição das informações. (FONTANELLA; RICAS; TURATO, 2008) Tendo em vista a garantia do anonimato, os participantes foram identificados com o termo "Entrevistado $(n)$ " seguido de um número.

Dos sete entrevistados, apenas um era do sexo masculino. Fato que pode ser atribuído ao cenário do estudo (grupo de convivência), que é predominante marcado pela presença feminina. Quanto à naturalidade, todos eram provenientes do interior do Estado. A faixa etária variou dos 60 aos 68 anos. Em relação ao estado civil, a maior parte dos entrevistados era casada. Foi verificado, ainda, que os participantes possuíam baixa escolaridade e que a renda per capita não foi superior a um salário mínimo, em sua maioria, proveniente da aposentadoria ou do auxíliodoença desses idosos. Vale ressaltar a predominância da família extensa na unidade doméstica, ou seja, em uma mesma residência, conviviam até três gerações.

As entrevistas foram realizadas no mês de outubro de 2013, sendo previamente marcadas, conforme a disponibilidade dos participantes e conduzidas pela pesquisadora principal deste estudo, de forma individualizada. Ocorreram na residência dos entrevistados, com exceção de um caso, devido a problemas familiares. Foi utilizada a técnica de entrevista semiestruturada, gravada com permissão prévia dos participantes e orientada por roteiro temático, abordando os seguintes temas: caracterização sociodemográfica, concepções de saúde e envelhecimento.

$\mathrm{Na}$ busca por atingir os significados manifestos e latentes do material empírico, têm sido desenvolvidas várias técnicas, dentre elas a análise temática, utilizada nesta pesquisa. A realização dessa técnica, segundo Minayo (2004, p.209) consiste em descobrir os "núcleos de sentido" que compõem uma comunicação, cuja presença ou frequência signifiquem alguma coisa para o objetivo visado.

Neste sentido, foi realizada a organização do material empírico e foram transcritas as entrevistas. Posteriormente, foram realizadas leituras sucessivas e exaustivas das informações, para haver a impregnação pelo material, permitindo que emergissem as categorias empíricas. Neste momento, os trechos relevantes para o estudo foram sendo destacados, codificados em unidades de significação e estas organizadas em dimensões, a seguir agrupadas em temas (exploração do material).

Sequencialmente, foi realizada a análise interpretativa das informações já agrupadas por núcleo de sentido. Para 
tanto, o material empírico da pesquisa foi analisado à luz das fundamentações da discussão teórica anteriormente realizada e da busca na literatura, à medida que novos significados e reflexões foram surgindo.

A identificação dos núcleos de sentido do material empírico resultou no seguinte tema central: saúde e envelhecimento. Tal tema foi subdividido nas seguintes dimensões: saúde: ausência de dor versus construção individual; envelhecer "não presta não"; autocuidado em saúde: práticas e padrões corporais.

\section{Resultados e discussão}

\section{Saúde e envelhecimento}

As discussões a seguir adotam como material empírico as concepções dos idosos frente aos principais questionamentos do estudo. A partir dessa consideração, deseja-se focar os aspectos mais relevantes relacionados às peculiaridades da saúde no envelhecimento, uma vez que esses aspectos são resultantes de processos biopsicossociais.

\section{Saúde: ausência de dor versus construção individual}

A compreensão de saúde pelos participantes apresentou-se de forma bem diversificada, interpretada em diferentes contextos. Segundo a Entrevistada 5, a dor está inserida no processo de saúde, ou seja, há uma coexistência da tríade saúde-dor-doença. Para ela, o fato de se apresentar dor não anula a saúde. Mediante tal discurso, salienta-se o estudo de Ceccim et al. (2012), ao afirmarem que saúde e doença não são conceitos opostos, nem tampouco definitivos. Para esses autores, o conceito de saúde resgata um sentido singular e subjetivo. Deste modo, quando se fala a respeito de saúde fazendo referência à dor ou ao prazer, ou outras dimensões subjetivas, compreendese a saúde como verdade do corpo, trazendo-a em uma visão não restrita a um valor universal.

A minha saúde é todo dia cheia de dor [risos] e problemas devido à diabete mesmo que aqui quando a gente faz qualquer arte a gente já piora. Um dia tá bem, outro dia não tá. (Entrevistada 5)

Enquanto que para a Entrevistada 2 "sentir-se bem" está associado a não apresentar queixas ou doenças, o que caracteriza a percepção dicotômica do conceito saúdedoença. Estes achados estão de acordo com o encontrado por Vilarino e Lopes (2008) em seu estudo, que buscou abordar as concepções e atitudes dos idosos acerca do processo de saúde e de adoecimento. Para essas autoras, essa visão biologicista é nitidamente influenciada pela predominância das práticas e políticas sanitaristas na sociedade brasileira, que privilegiam o modelo médicocurativo.

A minha saúde não tá bem, não, porque eu sinto dor na perna. Eu tenho artrose no joelho. (...) E eu tenho muito problema. (Entrevistada 2)

No entanto, apenas um entrevistado trouxe uma expressiva dimensão espiritual do processo saúde-doença. Para o Entrevistado 7, o médico é compreendido como intermediário ou facilitador do acesso entre o paciente e o superior divino. Neste processo, a cura é adquirida pela fé, tanto em Deus, quanto no profissional, por meio da 
transferência de poder, na seguinte lógica: o médico recebe o poder divino para a prescrição farmacológica, convertida em "força" para o paciente. Torna-se evidente na narrativa que o paciente também é responsável por esse processo, à medida que ele precisa ter fé.

A minha saúde não anda muito boa não, porque, do jeito que eu vivo, eu não posso dizer que ela é... só posso dizer que não tá boa. Só que a saúde que a gente, que eu sempre relembro que nosso pai que cura nós é Deus. A gente tem que ter fé em Deus e criar meio pra Ele dá a saúde da gente. Eu acredito, primeiramente, em Cristo e no médico. $O$ médico passar a medicação, né? É o acesso que Deus do poder dele pra dar força à gente. Agora se a pessoa vai fazer, vai pro médico, vai sem fé, toma o remédio sem fé, ele não pode conseguir melhorar nunca. Ele não tá com fé em Deus e não tá com fé naquele médico que passou o remédio pra ele. Que o médico, ele passa a medicação, mas é com a força de Deus (Entrevistado 7).

Mediante tal percepção, salienta-se o estudo de Inocêncio (2007), no campo da saúde, constando que as representações simbólicas nesse campo trazem determinados elementos relacionados à ligação com o sagrado no processo saúde-doença.

A fé, tão enfatizada pelo Entrevistado 7, caracteriza-se como um sentimento subjetivo, decorrente da necessidade do ser humano de depositar confiança em algo, seja esse algo concreto ou subjetivo, não podendo ser quantificado pela ciência. No caso da fé religiosa, ela contempla um diálogo entre o indivíduo e o divino, sendo que juntamente com a confiança desabrochada em seu íntimo, a pessoa recebe uma força ou apoio além da matéria. (ROBERTO, 2004)

\section{Envelhecer "não presta não"}

O trabalho de campo permitiu identificar ainda, o significado de envelhecimento como um fator negativo, para as Entrevistadas 1 e 4, tal como expressam os discursos a seguir:

Eu acho que eu tô bem. Até agora... Mas você sabe, né, uma pessoa de idade, minha filha....não presta não! (Entrevistada 1)

Mas daqui pra frente com fé em Deus vai melhorar mais. Melhorar um pouquinho, porque a gente quando vai ficando velho aparece tanta coisa [...] Eu cheguei o tempo de me ver criança. (Entrevistada 4)

Ao investigar percepções dos idosos acerca do envelhecimento, foi possível identificar o imaginário desse processo acompanhado de desgaste, limitações crescentes e perda de papéis sociais, implicações associadas à imagem da velhice na sociedade pós-industrial, frequentemente apresentada com conotação negativa quando baseada na decadência física. (GUERRA; CALDAS, 2010) Esta visão é consequência de uma sociedade que valoriza a produção, o rendimento, a juventude e a beleza, e alerta para a marginalização que uma definição tão negativa da velhice impõe aos idosos. (FERREIRA et al., 2010)

Interessante ressaltar que no relato da Entrevistada 4, o sentido de "voltar a ser criança" está relacionado à dependência de cuidados de terceiros, mais uma vez associado à concepção de limitação e decadência. 
Autocuidado em saúde: práticas e padrões corporais

O cuidado faz parte da essência de todo ser humano. É aquilo que se opõe ao descuido. Cuidar, mais que um ato, é uma atitude. Representa uma atitude de ocupação, preocupação e de responsabilização. (ALENCAR et al., 2008) Nesta perspectiva, o autocuidado em saúde engloba um conjunto de ações ou procedimentos de cada indivíduo destinado à manutenção da vida, da saúde e do bem-estar.

Associado a essa ideia, convém considerar o conceito de autonomia, palavra oriunda do grego que designa "aquele que estabelece suas próprias leis" (auto: de si mesmo; nomos: lei). De acordo com a OMS (2005), a autonomia é a habilidade de controlar, lidar e tomar decisões pessoais sobre como se deve viver diariamente, de acordo com suas próprias regras e preferências.

Deste modo, considerando tais conceitos, pode ser constatado nos relatos das Entrevistadas 1 e 3 o autocuidado em saúde, quando estas afirmam a realização da prática corporal, sistematicamente, bem como o monitoramento da pressão arterial, realizado pela última delas/idosa.

Eu acho que tô bem, porque eu faço caminhada, eu faço alongamento e aquilo eu me sinto muito bem, né? Me sinto mais "maneira". (...) Eu sei que por fora eu tô legal (...). Não sei por dentro, porque você sabe que pra dá um negócio na gente é de uma hora pra outra. (Entrevistada 1)

Eu acho que me ajuda muito é minhas caminhadas. Eu caminho de segunda a sexta. Eu tenho uns alongamentozinhos com os professores ali. Eu acho que isso ajuda muito. Aí eu tenho meu aparelhozinho de pressão em casa, que eu sempre fico vendo a minha pressão. (Entrevistada 3)
Cabe ressaltar que essa não é uma realidade abrangente a todos os idosos do território. Logo, esse fator pode ser atribuído à inserção desses idosos nos grupos de convivência, os quais visam como principal objetivo a promoção da saúde ${ }^{3}$. Importante destacar ainda, o cenário de Sobral nesse contexto das práticas promotoras de saúde, com a inserção de outras categorias profissionais na ABS, através do NASF e RMSF. Esse aspecto foi impulsionador para a construção e/ou fortalecimento desses grupos e de maior capilaridade dos saberes e práticas em saúde.

Retomando o discurso dos entrevistados sobre a concepção do processo saúde-doença, verificam-se aqui os relatos de outros fatores determinantes da saúde com perspectiva mais ampliada. Agora, "o sentir-se bem" não está mais associado somente ao "não sentir dor", mas também, à adoção de estilos de vida saudáveis.

Isso remete ao conceito trazido pela OMS, denominado de "envelhecimento ativo", caracterizado pelo processo de otimização das oportunidades de saúde, participação e segurança, com o objetivo de melhorar a qualidade de vida, à medida que as pessoas ficam mais velhas. (OMS, 2005)

Destaca-se ainda, a contribuição das tecnologias leves em tal estudo, à medida que incorporam a porção subjetiva no processo de trabalho e reconhecem esses idosos como sujeitos protagonistas no cuidado em saúde referenciado em suas necessidades singulares. Desta maneira, as falas acima retratam a autonomia na busca por melhorias na saúde e tornam evidente a necessidade de reorganização dos processos de trabalho, embasada na responsabilização,

3 A promoção de saúde caracteriza-se pela constatação de que a saúde é produto de um amplo espectro de fatores relacionados à qualidade de vida, incluindo práticas alimentares saudáveis, oportunidades de educação ao longo de toda a vida e outros determinantes de saúde. (ALENCAR et al., 2008) 
no cuidado, na escuta e no envolvimento afetivo com o outro.

Outro aspecto interessante observado frequentemente na pesquisa, contrário às expectativas iniciais, refere-se ao monitoramento do peso corpóreo relacionado a um ideal de corpo. Tal predominância desta afirmativa pode ser observada no depoimento abaixo:

[...] Eu tenho medo de engordar agora. Olha, eu tava pesando cinquenta e cinco quilos, agora eu tô pesando sessenta e seis quilos agora. Aí eu não sei o que fazer porque eu não quero aumentar o peso, eu quero é diminuir um pouco. Aí eu não sei o que fazer não. Tava me pesando e não diminuo de jeito nenhum [...]. (Entrevistada 3)

Diante disso, pode ser constado que a ideologia do "corpo lipofóbico" não está restrita apenas à população jovem, e nem tão somente à classe média. Este aspecto pode ser atribuído ao contexto do cenário brasileiro, evidenciado pela epidemia da obesidade e consequentes reconstruções das políticas de saúde e das abordagens profissionais, voltadas para o enfretamento da obesidade e das doenças que a ela podem estar associadas.

Historicamente, a corpulência era destacada na sociedade como sinal de prosperidade e respeitabilidade, portanto, do ponto de vista moral e da ótica estética, a obesidade era vista como atributo positivo. (SANTOS, 2011) No entanto, na contemporaneidade, observam-se padrões corporais próprios relacionados ao corpo, em que este assume um aspecto existencial fundamental porque é por intermédio dele que os sujeitos manifestam-se no mundo. Desta forma, existe um sistema de códigos para viver um corpo que é interiorizado e manifestado por um determinado grupo social. (WANDERLEY; FERREIRA, 2010)
A Entrevistada 3, ao afirmar "medo de engordar", denota sofrimento e aponta que dentro da esfera social, a obesidade é concebida como um estado desviante dos padrões de normalidade na cultura.

Desta maneira, mediante tais discussões, tornaramse evidentes as concepções dos idosos sobre saúde e envelhecimento, resultantes de processos históricos, sociais, culturais e biológicos.

\section{Conclusões}

Frente às constatações deste estudo foi fundamental perceber como se configuram as percepções dos idosos no processo do envelhecimento. Envelhecimento aqui avaliado não apenas na perspectiva de idade cronológica, e sim privilegiando as dimensões subjetiva, biológica, social e cultural desse fenômeno.

Emergiram da análise interpretativa dos discursos dos participantes, diferentes concepções de saúde embasadas nas limitações biológicas decorrentes do envelhecimento, com a associação da saúde à ausência de dor, como também a perspectiva do autocuidado, envolvendo adoção de mudança de estilo de vida, tais como práticas corporais e padrões de corpo. Foi relatada, ainda, a dimensão espiritual no processo saúde-doença, ilustrada pela cura através da fé.

Deste modo, é relevante destacar que essas percepções resgatam a singularidade e subjetividade dos conceitos de saúde e envelhecimento, resultantes de processos históricos, sociais, culturais e biológicos. Por um lado, o imaginário desse processo desenrola-se com desgastes e limitações associadas a uma conotação 
negativa e por outro, surgem, gradativamente, concepções que contemplam o envelhecimento ativo, com o objetivo de melhorar a qualidade de vida.

Mediante o processo das transições demográfica, epidemiológica e nutricional no Brasil, surgem desafios para o poder público, uma vez que demandam a habilidade de (re)produzir políticas públicas, programas e estratégias que respondam às necessidades referentes a esse contexto.

Diante de tal cenário, podem ser eleitas como prioridades tanto a formação de recursos humanos para serviços geriátricos e gerontológicos, como o fortalecimento da Atenção Básica por meio da Estratégia Saúde da Família, de modo a propor uma atenção à saúde integral e contínua, com medidas promocionais de proteção específica, além/ através da identificação precoce dos agravos de saúde mais frequentes.

Importante considerar também, neste estudo, a realização da escuta desses idosos como proposta das tecnologias leves em saúde, com significados latentes sobre saúde e envelhecimento que emergem do contexto singular e subjetivo de cada entrevistado. Assim, esperase que as discussões suscitadas possam contribuir para práticas profissionais reconhecedoras e impulsionadoras do protagonismo dos sujeitos, no processo de cuidado em saúde, pautadas no diálogo e nas relações de vínculos.

Destaca-se que o presente estudo não pretendeu exaurir a temática e, ainda, propõe a necessidade da realização de pesquisas que englobem idosos não participantes de grupo de convivência, a fim de comparar as concepções desses sobre saúde e envelhecimento, incluindo uma pesquisa que envolva a análise da abordagem em alimentação e nutrição dos profissionais de saúde da ESF.

\section{Referências}

ALENCAR, M.S.S. et al. Os aportes sócio-políticos da educação nutricional na perspectiva de um envelhecimento saudável. In: Revista de Nutrição. n.21, v.4, 2008.

BRASIL. Ministério da Saúde. Portaria do Gabinete do Ministro de Estado da Saúde de no 2.528 de 19 de outubro de 2006, que aprova a Política Nacional de Saúde da Pessoa Idosa. Brasília: Diário Oficial, 2006.

BOSI, M.L.M. Pesquisa qualitativa em saúde coletiva: panorama e desafios. In: Ciência \& Saúde Coletiva. v.17, n.3, 2012.

CAMARANO, A.A.; PASINATO, M.T. O envelhecimento populacional na agenda das políticas públicas. Rio de Janeiro, IPEA, 2005. Disponível em: <http://www.ucg.br/ ucg/unati/ArquivosUpload/1/file/Envelhecimento\%20 Populacional $\% 20$ na $\% 20$ Agenda $\% 20$ das $\% 20$ Pol\%C3\%ADticas\%20P\%C3\%BAblicas.pdf>. Acesso em: 28 abr 2013.

CECCIM, R.B. et al. Saúde e doenças: dois fenômenos de vida. Curso de Formação de Facilitadores de Educação Permanente em Saúde. Coordenação de Educação a Distância. Escola Nacional de Saúde Pública Sérgio Arouca. Fundação Oswaldo Cruz. p.27-35, 2012.

FACCHINI, L.A. et al. Avaliação de efetividade da Atenção Básica à Saúde em municípios das regiões Sul e Nordeste do Brasil: contribuições metodológicas. In: Caderno de Saúde Pública, Rio de Janeiro, 24 Sup 1, S159-S172, 2008.

FAZZIO, D.M.G. Envelhecimento e qualidade de vida: uma abordagem nutricional e alimentar. In: Revisa. v.1, n.1, p.76-88, 2012. 
FERREIRA, O.G.L. et al. O envelhecimento ativo sob o olhar de idosos funcionalmente independentes. In: Revista da Escola de Enfermagem da USP. v.44, n.4, p.1065-1069, 2010.

FONTANELLA, B.J.B.; RICAS, J.; TURATO,E.R. Amostragem por saturação em pesquisas qualitativas em saúde: contribuições teóricas. In: Caderno de Saúde Pública. v.24, n.1, p. 17-27, 2008.

GUERRA, A.C.L.C.; CALDAS, C.P. Dificuldades e recompensas no processo de envelhecimento: a percepção do sujeito idoso. In: Ciência \& Saúde Coletiva. v.15, n.6, p.2931-2940, 2010.

INOCÊNCIO, D. Entre a ciência e a crença: A postura médica frente à "Cura Religiosa". In: Revista Âncora. v. 3, n. 2, p. 3049 , 2007. Disponível em: <http://www.revistaancora.com. br/revista_3/03.pdf30>. Acesso em: 18 de fev. de 2014.

KRELING, N.H. O envelhecimento do trabalhador impõe novos desafios às políticas públicas. In: Indicadores Econômicos. FEE, Porto Alegre, v. 38, n. 1, p. 47-62, 2010.

MINAYO, M.C.S. O desafio do conhecimento: pesquisa qualitativa em saúde. 8.ed. São Paulo: Hucitec, 2004.

MONDINI, L.; GIMENO, S.G.A. Transição Nutricional: significado, determinantes e prognóstico. In: TADDEI, J.A.A.C. et al. (Edit.). Nutrição em saúde pública. Rio de Janeiro: Rubio, 2011.

MOREIRA, J.O. Mudanças na percepção sobre o processo de envelhecimento: Reflexões preliminares. In: Psicologia: Teoria e Pesquisa. v. 28 n 4, p.451-456, 2012.

OMS. Envelhecimento ativo: uma política de saúde. Tradução Suzana Gontijo. - Brasília: Organização PanAmericana da Saúde, 2005.
PESSANHA, R.V.; CUNHA, F.T.S. A aprendizagem-trabalho e as tecnologias de saúde na Estratégia Saúde da Família. In: Texto Contexto de Enfermagem, Florianópolis, v.18, n.2, p.233-40, 2009.

ROBERTO, G.L. Espiritualidade e saúde. In: TEIXEIRA, E.F.B.; MÜLLER, M.C.; SILVA, J.D.T. (org.). Espiritualidade e qualidade de vida. Porto Alegre: EDIPUCRS, 2004.

SANTOS, C.R.A. Os sabores da Sociedade. In: TADDEI, J.A.A.C. et al. (Edit.). Nutrição em saúde pública. Rio de Janeiro: Rubio, 2011.

WANDERLEY, E.N.; FERREIRA, V.A. Obesidade: uma perspectiva plural. In: Ciência \& Saúde Coletiva. v.15, n.1, p.185-194, 2010.

WONG, L.L.R.; CARVALHO, J.A. O rápido processo de envelhecimento populacional do Brasil. In: Revista Brasileira de Estudos de População. v.23, n.1, p.5-26, 2006.

VERAS, R. Saúde pública e envelhecimento. In: Caderno de Saúde Pública. v.19, n.3, p. 700-701, 2003.

VILARINO, M.A.M.; LOPES, M.J.M. Envelhecimento e saúde nas palavras de idosos de Porto Alegre. In: Estudos interdisciplinares sobre envelhecimento, Porto Alegre, v.13, n.1, p.63-77, 2008. 


\section{MUITO ALÉM DO PESO: REFLEXÕES SOBRE CORPO, OBESIDADE E SAÚDE EM MULHERES USUÁRIAS DA ESTRATÉGIA SAÚDE DA FAMÍLIA}

Fátima Café Ribeiro dos Santos Ana Helena Araújo Bomfim Queiroz Manoel Artur Ferreira Sousa Filho

Introdução

Este estudo é fruto do trabalho de conclusão da Especialização em caráter de Residência Multiprofissional em Saúde da Família. O interesse pelo estudo do corpo e da obesidade teve um despertar ainda na graduação em Nutrição da primeira autora, e mostrou-se mais claro e intenso com a vivência enquanto residente, inserida nas atividades coletivas na Estratégia Saúde da Família (ESF) de Sobral - Ceará, especificamente com as atividades ligadas às práticas corporais. O convívio com as mulheres participantes do grupo de práticas corporais estimulou a vontade de compreender, através de seus relatos, as percepções sobre seus corpos, taxados, muitas vezes, de excessivos, pesados e que, nas danças do grupo, apresentavam-se como corpos 
maleáveis, leves, expressivos e flexíveis. Também houve a aspiração em expandir tal discussão acerca da obesidade, abordada no campo estritamente biológico, nas práticas cotidianas dentro do Centro de Saúde da Família (CSF).

O corpo é uma temática que, ao longo da história, tem instigado os mais diversos autores e tem sido estudado pelas mais diversas vertentes das ciências, como: a Sociologia, Antropologia, Filosofia, Biologia entre outros. Luz (2007) comenta que o corpo é um conceito polissêmico, possuindo os mais diversos significados. É o modo com que os indivíduos revelam-se no mundo e mostram sua posição na sociedade. Dentro dessa perspectiva, o corpo sobrepõese aos limites do biológico, às condições materiais de vida, e assume também dimensões socioculturais fundamentais. (FERREIRA; MAGALHÃES, 2006)

No mundo contemporâneo, tem sido estudada a corporeidade diretamente ligada aos valores atuais, em que o corpo é visto enquanto um objeto privilegiado da reflexão sobre a vida social e a condição humana. Santos (2008) compartilha a discussão do corpo como algo em construção do próprio ser, a própria identidade.

Os padrões de beleza e o ideal de mulher sofreram transformações desde o final da Idade Média até a Idade Moderna. $O$ excesso de peso foi visto por séculos como referencial de beleza, status. Ao longo da história, o sobrepeso masculino era associado ao poder, comando e temor, enquanto o sobrepeso feminino era associado à maciez, passividade e desamparo, sugerindo a necessidade de cuidado. Estas características simbólicas mudaram radicalmente, uma vez que a referência central do corpo contemporâneo passou a ser o corpo magro, leve, flexível e, ao mesmo tempo, rígido. (SANTOS, 2008)

Fischeler (2005) reflete que a contemporaneidade vivencia uma época denominada de "lipofobia", em que há uma obsessão pela magreza e uma rejeição obsessiva à obesidade. Dessa forma, a sociedade contemporânea valoriza a magreza de tal forma que transformou a gordura em um símbolo de falência moral. $\mathrm{O}$ gordo, mais do que expor um peso socialmente inadequado, é imbuído de um caráter negativo e depreciativo. (VASCONCELOS et al., 2004)

A Organização Mundial de Saúde (OMS) define a obesidade como o acúmulo anormal ou excessivo de gordura. E pode ser compreendida como um agravo de caráter multifatorial, envolvendo desde questões biológicas, históricas e ecológicas, até econômicas, sociais, culturais e políticas. (BRASIL. MINISTÉRIO DA SAÚDE, 2006) Atualmente, é considerada uma patologia e um importante problema de saúde pública. De acordo com relatório publicado pela OMS em 2012, nos dias atuais, meio bilhão de pessoas, ou seja, $12 \%$ da população mundial são consideradas obesas. Em função da dimensão do sobrepeso e da velocidade de seu crescimento, em diversos países do mundo, a obesidade tem sido definida como uma pandemia, atingindo tanto países desenvolvidos como em desenvolvimento, entre eles, o Brasil. (OMS, 2012)

O país, a partir da metade do século 20, passou por uma importante mudança denominada de transição nutricional, com a diminuição da desnutrição infantil e consequente aumento da obesidade em adultos. Este processo foi fortemente relacionado às modificações no padrão alimentar da população brasileira, bem como às modificações sociais e demográficas. Condicionantes sociais, econômicos e culturais estão diretamente relacionados a esse processo, como a inserção da mulher no mercado de trabalho; o êxodo rural; o aumento populacional nos centros urbanos e a diminuição do esforço físico; menor gasto energético, tanto no trabalho quanto na rotina diária; assim como a crescente industrialização, comercialização e propaganda de alimentos. Este cenário apresenta um 
significativo paradoxo com a diminuição da desnutrição, existência de carências nutricionais e aumento da obesidade nos mesmos grupos populacionais. (BRASIL. MINISTÉRIO DA SAÚDE, 2006; BATISTA FILHO, RISSIM, 2003)

Segundo levantamento da pesquisa de Vigilância de Fatores de Risco e Proteção para Doenças Crônicas por Inquérito Telefônico, o excesso de peso atinge $48,2 \%$ da população brasileira. O percentual de mulheres acometidas por excesso de peso é de $44,7 \%$. Um dado relevante, quando analisado por região, é o do estado do Ceará, que apresenta um percentual de excesso de peso feminino de $54,7 \%$, valor/índice mais alto que o do perfil nacional. (BRASIL. MINISTÉRIO DA SAÚDE. SECRETARIA DE VIGILÂNCIA EM SAÚDE, 2011)

Buss (2000) mostra que promover saúde requer um olhar ampliado sobre as questões que determinam e condicionam as demandas relativas à saúde na sociedade. A Promoção da Saúde sugere articulação entre saberes técnicos e populares. Pensar nela requer um olhar amplo, enxergando e propondo ações que englobem o ambiente físico, social, político, econômico e cultural, através de políticas públicas e de condições favoráveis ao desenvolvimento da saúde, do empoderamento dos indivíduos e das coletividades.

As práticas corporais atuam como dispositivos que propiciam a melhoria da saúde da população, a redução dos agravos e dos danos decorrentes das Doenças Crônicas Não Transmissíveis (DCNT), favorecendo a redução do consumo de medicamentos e a formação de redes de suporte social, além de possibilitar a participação ativa dos usuários na elaboração de diferentes projetos terapêuticos. Essas práticas atuam como elementos fundamentais para a aquisição e manutenção de melhoria da qualidade de vida. (SILVA et al., 2010; ZAMAI e BANKOFF, 2010)
A Atenção Primária à Saúde, por ocupar o papel central na estruturação do Sistema Único de Saúde (SUS) do Brasil, constitui-se no espaço que possibilita o desenvolvimento de ações entre diversos setores e entre diversos atores, na perspectiva de atuar na melhoria da saúde da população. Pela sua influência direta no desenvolvimento das DCNT, a efetivação de ações de alimentação e nutrição na atenção primária pode contribuir com a melhoria da saúde da população brasileira. (SILVA; BAIÃO; SANTOS, 2013)

A integralidade configura-se como um dos princípios do SUS, assegurada na Constituição, e pauta-se no respeito, no cuidado de pessoas, grupos e da coletividade, percebendo o usuário como sujeito inteiro, histórico, social e político, articulado ao seu contexto familiar, ao meio ambiente e à sociedade na qual está inserido. (BRASIL. ASSEMBLEIA CONSTITUINTE, 1988)

Cecim e Feuerwerker (2004) abordam que a APS desempenha um papel estratégico na dinâmica de funcionamento do SUS, por seu estabelecimento de relações contínuas, o que permite uma maior aproximação com a população, tendo como princípio a atenção integral à saúde, baseada nas necessidades sociais por saúde. Em todas as suas modalidades de intervenção, a atenção básica deve buscar a atenção integral e de qualidade, bem como a resolutividade e o fortalecimento da autonomia das pessoas no cuidado à saúde, estabelecendo articulação orgânica com o conjunto da rede de serviços.

O cuidado, na perspectiva da integralidade, necessita do reconhecimento da complexidade das/do quanto são complexas as necessidades relacionadas à saúde de quem é cuidado, das diversas tecnologias possíveis de serem construídas e aplicadas no processo de trabalho. No trabalho em saúde, aliás, as relações que valorizam a subjetividade das pessoas em momentos de diálogo, troca, 
escuta e cumplicidade, nos quais há produção de uma responsabilização dos problemas a serem trabalhados, pautam-se no que se configura como tecnologias leves. (SILVA; SENA, 2008)

Mehry (2002) aponta que a tecnologia em saúde engloba os saberes utilizados na construção dos produtos únicos nos serviços de saúde. Refere ainda, que as tecnologias leves condensam relações de interação e subjetividade, possibilitando produzir acolhimento, vínculo, responsabilização e autonomização.

Freitas et al. (2011) afirmam que a nutrição reproduz o modelo biomédico, centrado na doença e não na história do adoecimento, quando não leva em conta a cultura, condições sociais e históricas que abarcam os temas da alimentação, os processos simbólicos e emocionais que intercedem tanto na doença como no tratamento dietético. Ferreira e Magalhães (2007) apontam que o desafio encontrado pela categoria dos nutricionistas quanto à adoção do modelo de atenção, sob o enfoque da integralidade, está ligado à mudanças estruturais, que têm seu início na própria formação acadêmica do profissional.

Deste modo, esta pesquisa tem como objetivo analisar a relação corpo, excesso de peso e saúde para as mulheres do Grupo da Paz do Centro de Saúde da Família Terrenos Novos de Sobral - Ceará, buscando caracterizar o grupo de mulheres e investigar suas percepções acerca desses indicadores. Pretendemos contribuir no sentido de ampliar tanto a discussão acerca do corpo, obesidade e saúde, quanto o olhar sobre esta temática, para além do campo estritamente biomédico.

\section{Metodologia}

Esta pesquisa caracteriza-se como estudo exploratório de natureza qualitativa. Para Minayo (1998), esse método aplica-se ao estudo da história, das representações, relações, crenças, percepções e opiniões, tendo como tarefa central a compreensão da realidade humana vivida socialmente. O modelo qualitativo de compreensão dos fenômenos privilegia o significado das práticas e escolhas sociais, e não a quantificação dos fenômenos. (FERREIRA; MAGALHÃES, 2006)

O cenário da pesquisa foi o bairro dos Terrenos Novos localizado na Cidade de Sobral, zona norte do estado do Ceará. Segundo Bonfim (2008), foi criado em 1982, através de um programa da habitação popular municipal, em que foram distribuídos os lotes de terra para a construção das casas, tendo sido denominado Cidade José Euclides I. De acordo com os relatos dos moradores mais antigos, a oferta das terras ocorreu de forma desordenada e sem nenhuma estruturação prévia, como terraplanagem, esgotamento sanitário e calçamento das ruas. A população é composta de 14.545 habitantes, sendo o percentual do sexo feminino de 51\%. (BRASIL. MINISTÉRIO DA SAÚDE, 2012) Em relação à renda, grande parte da população é caracterizada como de baixa renda, tendo como base de sua ocupação o trabalho informal no comércio, no serviço doméstico, nas fábricas de calçados e na produção de chapéu de palha.

O grupo pesquisado é composto por mulheres acompanhadas pelo CSF Everton Mont'Alverne, no bairro dos Terrenos Novos. Esse grupo de promoção da saúde de mulheres com sobrepeso e obesidade, acompanhadas pelo CSF, surgiu com turmas de profissionais da RMSF. Com a inserção dos residentes da 9. cursos de Educação Física e Nutrição, foi proposto que o 
grupo fosse ampliado e a entrada dos participantes livre, focando não somente em uma patologia. Desta forma, qualquer usuária que desejasse ou fosse encaminhada para o grupo seria acolhida.

O grupo possui uma abordagem ampliada, com foco em promover a autogestão do cuidado, tendo como principal atividade as práticas corporais, que englobam a ginástica comunitária, oficinas temáticas, rodas de conversa e o Café da Gentileza. ${ }^{1}$ As atividades ocorrem duas vezes por semana (terça e quinta-feira), na Associação Comunitária Benedito Tonho. O grupo possui uma média de 40 participantes, na faixa etária de 20 a 60 anos. Os encontros são facilitados por residentes da RMSF.

As participantes da pesquisa foram as mulheres usuárias do Centro de Saúde da Família, participantes do Grupo da Paz. Os critérios de inclusão utilizados foram: participantes do grupo que já tivessem realizado acompanhamento nutricional individual pela pesquisadora, que apresentassem excesso de peso segundo a classificação do IMC e que participassem do grupo pelo período mínimo de seis meses. Doze participantes enquadraram-se nos critérios e, no total, foram realizadas seis entrevistas.

Os dados foram coletados por meio de entrevistas individuais semiestruturadas, realizadas no período de janeiro e fevereiro de 2014. Segundo Minayo (2004), a entrevista configura-se como meio de coleta de informações de determinado tema científico que, acima de tudo, caracteriza-se como uma conversa a dois ou entre diversos interlocutores, partindo da iniciativa do entrevistador. A

\footnotetext{
1 Um momento de celebração do grupo ocorre na primeira terça-feira de cada mês. Neste dia, cada integrante que possa leva um alimento, que tenha disponível em casa para partilhar com as outras participantes. A cada encontro é sugerida uma temática, escolhida previamente pelas participantes, sendo esse o assunto norteador da roda de conversa.
}

entrevista semiestruturada possuiu um roteiro norteador com perguntas que guiaram a entrevista.

As entrevistas ocorreram na casa das participantes, de forma individual, com horário previamente combinado e foram gravadas com consentimento prévio, sendo posteriormente transcritas pela pesquisadora.

O número de entrevistas foi delimitado através do critério de saturação, que se entende como o conhecimento desenvolvido pelo pesquisador no campo, a ponto de compreender a lógica interna do grupo ou coletividade pesquisado. (MINAYO, 2004)

No intuito de preservar a identidade das participantes, foram utilizados nomes fictícios escolhidos por elas, o que fez surgir os mais diversos nomes de mulheres do contexto histórico, bíblico e midiático.

Para análise das informações, foi utilizada a técnica de Análise de Conteúdo que, segundo Minayo (2004), é a expressão mais comumente usada para representar o tratamento de dados de uma pesquisa com cunho qualitativo, mas que se amplia simplesmente de um mero método técnico. Para Bardin (2011), a Análise de Conteúdo é um conjunto de técnicas de análise de comunicação baseado em procedimentos sistemáticos e objetivos, com a finalidade de descrever o conteúdo das mensagens, indicadores que permitam a dedução de conhecimentos relativos às condições de produção e recepção dessas mensagens.

A modalidade escolhida dentro da Análise de Conteúdo foi a Análise Temática, que busca descobrir os chamados núcleos de sentido que compõem a comunicação, cuja frequência ou presença signifiquem algo ao objeto analítico que se pretende pesquisar. 
$\mathrm{Na}$ análise temática que gerou os núcleos de sentido do material pesquisado, surgiram sete temas centrais: percepção corporal; percepção das mudanças; estigma; como cheguei no grupo; motivação; redes construídas e a percepção de saúde. Com tais núcleos foi construída uma rede interpretativa do estudo, o qual seguiu os critérios éticos estabelecidos na Resolução n. 466 de 2012, das Diretrizes e Normas Regulamentadoras de Pesquisa Envolvendo Seres Humanos do Conselho Nacional de Saúde. (BRASIL. CONSELHO NACIONAL DE SAÚDE, 2012)

\section{Análise e discussão}

A fala das mulheres pesquisadas foi muito nítida, com abundância de detalhes, quanto à compreensão delas sobre corpo, obesidade e saúde, o que tornou mais fácil apresentar, de forma detalhada e diversa, a percepção das mesmas sobre seus corpos, como lidam com ele cotidianamente e o que pensam sobre saúde, no intuito de enriquecer a discussão dessas temáticas.

\section{Grupo}

\section{As Mulheres}

As mulheres entrevistadas possuíam idade entre $30 \mathrm{e}$ 68 anos, com idade média de 45 anos. Em relação ao estado civil, consideraram-se casadas, ou possuidoras de união estável e tinham em média, três filhos. Em relação à origem, todas relataram ser do Estado do Ceará, sendo que três delas eram naturais do município de Meruoca e nenhuma referiu ser Sobral. No que tange à ocupação, todas declararam-se donas de casa, sendo que duas indicaram possuir outras atividades para complementação de renda: de artesã e de vendedora avulsa. Em relação à escolaridade, a maioria referiu possuir o primeiro grau incompleto, apenas uma asseverou formação de segundo grau completo. Quanto à religião, três delas consideraram-se evangélicas, sendo duas Testemunhas de Jeová e uma Adventista do Sétimo dia e três posicionaram-se como católicas.

\section{Como cheguei}

Emergiram no material empírico, incessantes relatos sobre a contribuição do grupo na vida dessas mulheres, nas quais percebeu-se a efetividade das atividades coletivas promotoras de saúde, devido à capilaridade da atuação multiprofissional no território. Ao se referirem ao Grupo, sem nenhuma exceção, essas mulheres trouxeram em suas falas uma grande carga de afetividade, vínculo, companheirismo e amorosidade. A forma como souberam e chegaram ao grupo aconteceu, principalmente, por meio dos encaminhamentos dos profissionais do Centro de Saúde e por convite de outras participantes.

O Grupo lá da Associação foi uma amiga que me falou, ela me convidou... Aí, eu disse: "tô dentro"! No dia seguinte, eu fui e gostei. Nossa! Como eu gostei. (suspiro) ... a ginástica pra mim vale muito mais do que o próprio medicamento que eu estou tomando... (IRMÃ DULCE) 


\section{Motivação}

Ao longo dos quase dois anos de reativação do Grupo, tendo o acompanhamento da equipe multiprofissional da Residência, passaram por ele cerca de 100 mulheres. A frequência média era de 45 mulheres por dia, sendo que, em alguns momentos, chegou a ter a presença de 60 mulheres.

A permanência nas atividades efetivou-se em decorrência de diversos fatores por elas relatados, dentre eles, os mais relacionados à melhoria física e da saúde como: a diminuição de dores, de desconfortos físicos e da depressão, além do controle da diabetes e da pressão arterial. Outro grande motivador apontado foi a rede de relações construídas, as amizades, os vínculos.

A rede de afetos construída possibilitou e criou dispositivos para o enfrentamento das dificuldades, na busca pela redução do excesso de peso e dos problemas de saúde. O reconhecimento, enquanto pares, possibilitou a construção de novos sentidos e valores em relação à visão de mulheres sobre seus corpos, tão taxados de excessivos.

Neste sentido, Mattos e Luz (2009) apontam que muitos indivíduos obesos conseguem um aconchego ao lado de outros que se encontram na mesma situação. Eles passam a compartilhar um sistema comum de valores, deixam de ser considerados indivíduos inexpressivos e passam a ser pessoas inteligentes e valorizadas no seio do próprio grupo, independente de sua aparência física. São redes de ajuda mútua que criam novos laços sociais. Constitui-se aí, uma nova ética da existência, baseada no vínculo ao "nós".

Pra mim, é o convívio. Fui mais assim pelas amizades, porque eu gosto dessa parte, de... ser distraída... de construir... fazer amizades... O convívio, a amizade que a gente faz, o companheirismo com todas. Sem falar que, a cada dia que a gente ia lá fazer os exercícios, a gente voltava pra casa com bem mais disposição... Eu gosto disso... E eu vejo o quanto isto me faz bem. (ANA)

O que me motiva é quando eu me sinto capaz de viver. Antigamente, quando eu não conhecia essa ginástica, eu passei um bocado de dia em casa muito mal... Então, a motivação é essa: eu chegar em casa com mais ânimo, com mais coragem... A gente saí de lá tão "manera", com tanta coragem pra fazer as coisas. Com uma vontade tão grande de viver... (IRMÃ DULCE)

\section{Redes Construídas}

Interessante observar que o Grupo toma uma dimensão ampliada na percepção dessas mulheres. Ele tornou-se um espaço de encontro, convívio, escuta e vínculo, de maneira que a convivência constitui-se em um dos motivadores da permanência e que possibilitou a construção de uma rede de relações que extrapola o espaço físico onde ocorrem as atividades.

Luz (2008) salienta que, para muitos indivíduos, algumas práticas corporais configuram-se como possibilidade de escape do isolamento social, bem como adquirem a capacidade de diminuir (ou eliminar) o "vazio" das relações sociais contemporâneas. As atividades físicas coletivas permitem, portanto, novos encontros, novos afetos e novas sociabilidades.

A ESF tem como um dos seus pilares a construção do vínculo entre os profissionais que nela atuam e a 
comunidade, de forma que esta aproximação possibilite o reconhecimento desses/de ambos como pares, permitindo o diálogo, a escuta qualificada e a criação de relações de confiança, acarretando maior efetivação das ações que promovam cuidado.

Porque, assim, Fátima, às vezes, a gente vê o nutricionista, o assistente social... óoooh! É a nutricionista! É a assistente social! Falar, às vezes, a gente tem até medo. Eu digo isso porque a gente conversa no dia a dia. E no Grupo faz ver que não é assim. São pessoas normais. São pessoas que a gente pode se "achegar", pode conversar, pode confiar. São pessoas acessíveis. Isso é importante, muito importante. (SARA)

Freitas et al. (2011), em seu estudo sobre a nutrição humanística, traz que a presença e o diálogo formam assim, uma intersubjetividade na nutrição, que se humaniza na parceria. A conduta do profissional pode ir além do diagnóstico, das normas e técnicas, pois a tendência da humanização leva-o a ver mais, a partir das palavras que fluem na linguagem. A atenção nutricional ao paciente obeso demonstra ser mais efetiva quando permeada pelo discurso mais humano, voltado para o cuidado e a relação sujeito-sujeito na comunicação. (OLIVEIRA et al., 2008)

A amizade influi... a alegria... minha motivação maior é essa também, de estar lá com elas. Só uma é, como aquele dizer, uma andorinha só não faz verão... Aquela alegria toda. É isso que me motiva. A minha saúde e até também é que, estando juntas, a gente até esquece que tem algum problema ou alguma doença que lhe pegue em casa. Lá com as meninas, ninguém sente é nada. (MARIA DA PENHA)
Em sua fala, a participante deixa clara sua percepção ampliada das relações estabelecidas no Grupo, relacionando a saúde e os laços afetivos. Maffesoli (1987) indica/ manifesta que, nas redes de amizade que se estabelecem em torno de um objetivo comum (estar junto), os integrantes organizam-se buscando estabelecer a solidariedade como forma de enfrentamento dos problemas decorrentes do adoecimento ou do próprio estigma da gordura. Constituise, portanto, uma nova solidariedade, reinvestida na forma de um grupo que luta contra a ideia do corpo gordo como um corpo adoecido.

\section{Corpo}

\section{Para além do Peso}

Nos depoimentos colhidos, fica evidente a percepção das mulheres do Grupo sobre seus corpos. O ideal de beleza e o padrão desejado por elas diferem do padrão de normalidade regido pela numeração do IMC. Nota-se um desejo de melhoria, porém, diferente dos atuais padrões de magreza.

A imagem corporal que é construída do próprio corpo é constituída e estruturada na mente das pessoas, envolvendo todos os sentidos, provenientes de experiências vivenciadas por um indivíduo, segundo os quais ele cria um referencial corpóreo de si mesmo. (PAULUCCI; FERREIRA, 2009)

No que tange à discussão acerca da classificação numérica do corpo, Carvalho e Martins (2004, p.1004) fazem uma reflexão acerca do estaticismo da antropometria, afirmando que a mesma só é capaz de analisar o que é palpável, visível, mensurável. Desta forma, esse método 
fundamenta-se em uma "representatividade" numérica e esvaziada de sentidos (supostamente neutra), que não permite um aprofundamento nos significados e sentidos que constituem as várias facetas de um "objeto complexo". No que diz respeito a tal discussão, fica nítida, na fala da participante, sua divergência, quando se refere ao limite estabelecido de normalidade científica. $O$ peso ideal, para ela, distancia-se significativamente do que considera aceitável, o peso real.

\section{Como eu vejo meu corpo atualmente?}

Um luxo! (risadas e alegria no olhar). Um luxo, em vista do que ele era. Hoje eu estou me sentindo muito bem. Para todos os sentidos, pra fazer minhas atividades em casa, para passear, até para me arrumar porque a minha autoestima estava láááá embaixo. Hoje ela tá lá em cima. Hoje eu estou com autoestima lá em cima. Hoje eu estou olhado pro meu corpo com todos os olhos que eu tenho (sorrisos). Hoje eu me admiro. (ANA)

Eu me vejo gordinha (risos). Eu queria era perder minha barriga e as gordurinhas do meu braço (risos). Tem gente que diz que não gosta do corpo, mas eu gosto. Só queria melhorar um pouco, mas eu gosto dele. Do jeito que tá aqui, eu gosto, mas queria melhorar mais. Sou gordinha, sou fofinha! (risos). Eu digo é muito "eu não sou gorda, eu sou é fofinha". Eu nunca quis ser magra não, só ter um corpo bom, bundona, pernona, peitão, menos barriga (risos). (ANA MARIA BRAGA)

Um fato interessante trazido pela participante mostra que o padrão de beleza por ela construído difere do padrão atual de magreza. Ela refere o desejo de reduzir medidas, mas sem a perda da sua corpulência. Seu ideal de beleza inclui "seios fartos e bunda grande". Um estudo realizado por Freitas (2002), na cidade do Salvador, demonstra que o ideal de beleza das mulheres das classes populares difere do discurso das mulheres da classe média. Nas classes populares, há o desejo do emagrecimento, desde que não promova a perda da corpulência, que marca as características do "padrão" da mulher brasileira.

\section{Percepção das Mudanças}

Quando questionadas sobre em que momento de suas vidas começou a ser percebido o ganho de peso e as mudanças corporais, as mulheres relataram dois momentos como marcantes: a gravidez e o casamento. A partir do casamento, essas mulheres passaram a ocupar um papel central na organização da casa, dos afazeres domésticos, nos cuidados com os filhos e com a alimentação da família, mesmo não sendo elas, provedoras financeiras do lar. Esse ganho foi principalmente percebido na gravidez do último filho.

Martins (2011) defende que o ganho de peso excessivo durante a gestação torna a mulher propensa à obesidade pós-parto. E que diversos estudos evidenciam a associação positiva entre o ganho ponderal excessivo na gestação e a retenção de peso por até três anos após o parto. Pesquisas realizadas (FERREIRA; MAGALHÃES, 2006; PINTO; BOSI, 2010), respectivamente, com mulheres da Rocinha, no Rio de Janeiro, e da periferia de Fortaleza obtiveram os mesmos relatos: a associação percebida, pelas mulheres pesquisadas, entre o ganho de peso excessivo e a maternidade. 


\section{Estigma}

A obesidade enquanto estigmatizadora produz discriminação, preconceito e exclusão social. Ouvir os sujeitos com essa condição é abrir uma escuta ao que está sendo dito e sentido, para possibilitar a ruptura de uma situação dada, que pode ser transformada no momento em que é discutida, socializada, polemizada e politizada. (FELIPPE et al., 2004)

As pessoas olham pra você e dizem: "Mulher, você está muito gorda, vai fazer uma dieta". Porque, às vezes, as pessoas acham que os gordinhos não sofrem. Mas a gente que é gordinha, a gente sofre. Eu, que sou uma pessoa assim, alegre, eu já sofri muito. Alguém diz uma coisa eu levo na brincadeira, mas depois eu estou lá arrasada. Às vezes, têm pessoas que acham que lhe ajudam lhe criticando, mas não ajudam. Pelo contrário, Ihe acabam mais. (ANA)

Segundo Melo (2006), na atualidade, a palavra "estigma" representa algo de mau, que deve ser evitado, uma ameaça à sociedade, isto é, uma identidade deteriorada por uma ação social. Para Goffman (1993, p.11), "La sociedad establece los medios para caracterizar a las personas y el complemento de atributos, que se perciben como corrientes y naturales a los miembros de cada una de esas categorías".

Isto é, o estigma da obesidade, atualmente mais se acentua, toma contornos de uma espécie de monstro moderno, uma deformidade física (e também moral) não sendo mais tolerado socialmente. (SANTOS, 2008)
Saúde

\section{Percepção de Saúde}

Nos relatos, foi possível perceber a pluralidade de percepções acerca da saúde. Em algumas falas, ficou clara a visão de saúde como ausência de doença, bastante relacionada à saúde como ausência de dor. Essa visão está muito ligada ao discurso médico-hegemônico de saúde percebida como ausência de doença. Em contraposição, quando instigada sobre saúde, a entrevistada manifestou outra percepção bastante rica, para além do corpo físico, trazendo a ideia de saúde como sentimento, como alegria, felicidade e vontade de viver. É possível também perceber que muitos sujeitos considerados doentes sob o ponto de vista médico-hegemônico, com olhar estritamente clínico, consideram-se bem de saúde e são considerados saudáveis em seu meio.

Saúde é você estar sempre alegre, feliz, sorrindo, brincando. Pra mim, minha filha, se eu parar com tudo isso é porque eu tô doente. Saúde, pra mim, é isso: alegria, felicidade, satisfação, é coragem de fazer seus serviços, suas atividades... É vontade de viver. Isso é que é saúde. Penso eu [...] (IRMÃ DULCE)

Canguilhem (2003) e Caponi (2005) remetem/ registram que as tentativas de definir objetivamente a saúde por meio de características funcionais e estatísticas produzem um corpo apagado do corpo subjetivo caracterizado. As sensações de dor, sofrimento, prazer, sempre trazidas ou lembradas quando se fala em saúde, indicam a necessidade de falar na primeira pessoa: ali onde o discurso médico insiste em falar na terceira pessoa. 
Também é possível afirmar que há uma parte do corpo humano vivo que é inacessível aos outros, que é, pura e exclusivamente, acessível a seu titular.

\section{Considerações finais}

A aproximação afetiva conquistada com essas mulheres, como pesquisadora, pelos dois anos no Grupo e pelas abordagens individuais, configurou-se como ponto extremamente positivo neste trabalho. As entrevistas fluíram com muita leveza, permeadas por afetos, e fez com que elas falassem sobre temas íntimos e subjetivos. Essa possibilidade concretizou-se, principalmente, por se tratar de uma pesquisa qualitativa. Ficou claro, após os dois anos de vivência com elas, que a percepção que possuem dos seus corpos extrapola uma visão "Muito Além do Peso", sendo este o nome dado a essa pesquisa.

Como objetivo, este trabalho pretendeu caracterizar o Grupo da Paz, bem como compreender a representação que as pesquisadas possuíam dos seus corpos, da obesidade e da saúde, tendo sido evidente nas análises e discussões o alcance desses indicadores.

A partir dos relatos das participantes, foi possível obter uma melhor compreensão da corporeidade, da saúde e da maneira como elas vivenciam, no seu cotidiano, a obesidade. Bem como observar a percepção que têm dos seus corpos, que diverge do padrão de normalidade atualmente definido, mas que também distancia-se do padrão que as mesmas almejam, ligado à manutenção da corpulência. De fato, elas não se percebem como obesas, estando este termo mais restrito aos profissionais da saúde. Usam outras categorias semânticas que possibilitam uma leveza maior no enfretamento às dificuldades do cotidiano.
Não se pode desconsiderar a magnitude da obesidade e que a mesma é um problema de saúde pública que acomete uma parcela significativa da população mundial. É preciso ter clareza de que essa é uma doença multifatorial, envolvendo mais que aspectos fisiológicos, psíquicos, emocionais, sociais, culturais e políticos, portanto, fazse necessária uma nova abordagem dos profissionais da saúde, considerando os diversos fatores relacionados ao cuidado da obesidade, uma vez que ao ser vista sob a ótica estritamente biológica, ela reduz um objeto tão complexo.

A percepção que as mulheres do Grupo da Paz possuem é ampla. Consideram um espaço de cuidado, de partilha, trocas, afetos, relações, configurando-se especialmente como um espaço promotor de saúde. A rede de afetos construída apresentou-se como um dos motivadores para a permanência delas no Grupo: elas citaram os laços, o vínculo, a amorosidade, que extrapola os limites físicos onde ocorrem as práticas. Essas redes criadas atuam como importante fator positivo no enfrentamento da obesidade e dos problemas de saúde.

Nas análises, percebeu-se a diversidade de concepções de saúde, ora ligadas ao entendimento mais biológico do assunto, como a ausência de dor, de desconfortos, a melhoria do sono, da disposição, ora ligadas à dimensão dos sentimentos, como a alegria e a felicidade, trazendo à tona outra dimensão de saúde.

Diante da complexidade do tema, é importante que o profissional nutricionista, que tem no seu cotidiano uma grande demanda, no sentido de abordar e tratar a obesidade, lance mão de abordagens que incluam o sujeito dentro do seu processo de cuidado, visto que esse possui suas próprias concepções sobre tal problema e que pode ter outra conotação dele a partir do local em que vive, das relações sociais que vivencia. É necessário um olhar 
sensível, uma escuta qualificada e a criação de vínculos na perspectiva de construir uma prática promotora de saúde.

\section{Referências}

BARDIN, L. Análise de Conteúdo. São Paulo: Edições 70, 2011.

BATISTA FILHO, M.; RISSIN, A. A transição nutricional no Brasil: tendências regionais e temporais. In: Cad. Saúde Pública, Rio de Janeiro, 2003.

BOMFIM, A.H. et al. Territorialização e inserção nos serviços de Saúde da Família: conhecendo a realidade de Terrenos Novos e Vila União. Sobral: UVA/EFSFVS, 2008.

BUSS, P.M. Promoção da saúde e qualidade de vida. In: Ciênc. Saúde Coletiva, 2000; v.5, p.163-177.

BRASIL. Assembleia Constituinte Constituição (1988). Constituição da República Federativa do Brasil. Brasília, DF, Senado, 1998.

BRASIL. Conselho Nacional de Saúde. Diretrizes e Normas Regulamentadoras de Pesquisas Envolvendo Seres Humanos - Resolução 466/12. Brasília, 2012.

BRASIL. Ministério da Saúde. Obesidade. Brasília: Ministério da Saúde, 2006.

Sistema de Informação da Atenção Básica, Brasília, 2012. Disponível em: <http://tabnet.datasus.gov.br/cgi/ deftohtm.exe?siab/cnv/SIABSCE.def>. Acesso em: 16 jul 2013.

BRASIL. Ministério da Saúde. Secretaria de Vigilância em Saúde. Vigitel Brasil 2011: Vigilância de Fatores de Risco e
Proteção para Doenças Crônicas por Inquérito Telefônico. Ministério da Saúde, Secretaria de Vigilância em Saúde Brasília: Ministério da Saúde, 2012.

CANGUILHEM, G. A saúde: conceito vulgar e questão filosófica. In: CANGUILHEM, G. (Org.) Escritos sobre a Medicina. Rio de Janeiro: Forense Universitária, 2005.

CAPONI, S. A saúde como abertura ao risco. In: CZERESNIA, D.; FREITAS, C.M. (Orgs.). Promoção da Saúde: conceitos, reflexões e tendências. Rio de Janeiro: Fiocruz, 2003.

CARVALHO, M.C; MARTINS, A. A obesidade como objeto complexo: uma abordagem filosófico-conceitual. In: Ciência \& Saúde Coletiva. v.9, n.4, p.1003-1012, 2004.

CECCIM, R.B.; FEUERWERKER, L.C.M. O Quadrilátero da Formação para a Área da Saúde: Ensino, Gestão, Atenção e Controle Social. In: PHYSIS, Rio de Janeiro, v.14, n.1, p.4165, 2004.

FELIPPE, F.M.L; FRIEDMAN, R; ALVES, B.S; CIBEIRA, G.H.; SURITA, L.E.; TESCHE; C. Obesidade e mídia: o lado sutil da informação. Revista Acadêmica do Grupo Comunicacional de São Bernardo. Ano1, n.2, dez/2004.

FERREIRA, V.A.; MAGALHAES. R. Nutrição e promoção da saúde: perspectivas atuais. In: Cad. Saúde Pública [online]. v.23, n.7, 2007, p. 1674-1681.

O corpo cúmplice da vida: considerações a partir dos depoimentos de mulheres obesas de uma favela carioca. In: Ciência \& Saúde Coletiva. v.11, n.2, p.483-490, 2006.

FISCHLER, C. Obeso benigno, obeso maligno. In: SANT ANNA, D.B (org.) Políticas do Corpo: Elementos para uma história das práticas corporais. São Paulo: Estação liberdade, 2005. 
FREITAS, M.C.S. Mulher ligth: Corpo, Dieta E Repressão. Imagens da mulher na cultura contemporânea / organizado FERREIRA, L.S.; NASCIMENTO. E.R. Salvador: NEIM/UFBA, 2002.

FREITAS, M.C.S; MINAYO, M.C.S; FONTES. G.A.V. Sobre o campo da Alimentação e Nutrição na perspectiva das teorias compreensivas. In: Ciência \& Saúde Coletiva, v.16, p.31-38, 2011.

GOFFMAN, E. Estigma: la identidad deteriorada. 5ed. Buenos Aires: Amorrortu, 1993.

LUZ, M.T. As novas formas da saúde: práticas, representações e valores culturais na sociedade contemporânea. In: Rev Bras Saúde Família. Brasília, v.9, p.8-19, maio/2008.

.O gordo em pauta: representações do ser gordo em revistas semanais. In: Ciênc. saúde coletiva. v.12, n.4, 2007.

MAFFESOLI, M. O Tempo das Tribos: O declínio do individualismo nas sociedades de massa. Rio de Janeiro: Forense-Universitária, 1987.

MARTINS, A.P.B.; BENICIO, M.H.D. Influência do consumo alimentar na gestação sobre a retenção de peso pós-parto. In: Rev Saúde Pública, v.45, n.5, 2011, p.870-877

MATTOS, R.S; LUZ, M.T. Coleção Pesquisa em Educação Física, v.8, n.4, 2009.

MEHHY, E.E. Saúde: a cartografia do trabalho vivo. São Paulo: Hucitec, 2002.

MELO, Z.M. Os estigmas: a deterioração da identidade social. 2006. Disponível em: <http://www.sociedadeinclusiva. pucminas.br/anaispdf/estigmas.pdf>. Acesso em: 03 ago 2013.
MINAYO, M.C.S. O desafio do conhecimento: pesquisa qualitativa em saúde. 8.ed. São Paulo: Hucitec, 2004.

. Pesquisa social: teoria, método e criatividade. 9ed. Petrópolis: Vozes, 1998.

OLIVEIRA, J.A.N; BARRETO, J.D; MELLO, A.O.; FREITAS, M.C.S; FONTES, G.A.V. Percepção dos obesos sobre o discurso do nutricionista: estudo de caso. In: FREITAS, M.C.S.F.; FONTES, G.A.V.; OLIVEIRA, N. (Org.). Escritas e narrativas sobre alimentação e cultura. Salvador: EDUFBA, 2008.

OMS. Estatísticas da Saúde Mundial 2012. Organização Mundial de Saúde: Genebra, 2012/ 16 de março de 2012. Disponível em: <http://http://www.who.int/gho/ publications/world_health_statistics/2012/en/>. Acesso em: 16 ago 2013.

PAULUCCI, E.Z.C.; FERREIRA, A. Corpo e imagem: relações entre medidas antropométricas e aceitação pessoas da imagem corporal em praticantes de jazz de competição. In: Rev. Bras. Educação Física Esporte Lazer Dança. v,4, n.2, 2009, p.53-61.

PINTO, M.P.; BOSI, M.L.M. Muito mais do que pe(n)sam: percepções e experiências acerca da obesidade entre usuárias da rede pública de saúde de um município do Nordeste do Brasil. Fortaleza. Physis, Rio de Janeiro. v.20, n.2, p.443-457, 2010.

SANTOS, L.A.S. O corpo, o comer e a comida: um estudo sobre as práticas corporais e alimentares no mundo contemporâneo. Salvador: Edufba, 2008.

SILVA, A.F.A.C.; BARRO, C.L.M. O profissional de Educação Física e a promoção da saúde: enfoque dos programas de saúde da família. In: Revista Digital - Buenos Aires, 2010; ano15 n.145. 
SILVA, J.P..; BAIÃO, M.R.; SANTOS, M.S. Ações de Alimentação e Nutrição na Atenção Básica. In: BARROS, D.C.; SILVA, D.O.; SANTOS, M.M.A.S.; BAIÃO, M.R. (Org.). Alimentação e Nutrição: fundamentos para a prática em saúde coletiva. Rio de Janeiro: EAD/ENSP; 2013. p.59-105.

SILVA, K.L.; SENA R..R. Integralidade do cuidado na saúde: indicações a partir da formação do enfermeiro. In: Revista Escola de Enfermagem USP. São Paulo, v.42, n.1, 2008. p.48-56.

VASCONCELOS, N.A. de; SUDO, I.; .SUDO, N. Um peso na alma: O corpo gordo e a mídia. Revista Mal-estar e Subjetividade, v.4, n.001. Universidade de Fortaleza. Fortaleza, Março, p.65-93, 2004.

ZAMAI, C.A.; BANKOFF, A.D.P. Nível de atividade física e indicadores de qualidade de vida de colaboradores da Unicamp: Análise através do Programa Mexa-se Unicamp. XI Simpósio Nordestino de Atividade Física \& Saúde, 2010, Aracaju - Sergipe. XI Simpósio Nordestino de Atividade Física \& Saúde: da evidência a intervenção. Aracaju - Sergipe: UFS, 2010.

\title{
VIOLÊNCIA DOMÉSTICA E SUAS INTERFACES COM AS QUESTÕES DE IDENTIDADE E GÊNERO
}

\author{
Maria da Glória dos Santos Ribeiro \\ Maria Michelle Bispo Cavalcante
}

\section{Introdução}

Desde a metade do século XIX até depois da Primeira Guerra Mundial, a industrialização e a urbanização alteraram a vida cotidiana, particularmente das mulheres, que passaram a ocupar o espaço das ruas, a trabalhar fora de casa, a estudar, etc. Essas transformações resultaram em um processo político desencadeado pelo feminismo que buscava estender a visibilidade e legitimidade das mulheres como sujeitos políticos implicando, sobretudo, na crescente participação das mulheres no trabalho remunerado e no orçamento familiar, junto com a aceitação social da atividade sexual feminina não reprodutiva e fora do casamento, o que representou a expressão de uma "nova mulher"; "independente", negociando sua participação no mercado de trabalho, com atividade e autonomia sexual, uma vez que, alcançou o controle da natalidade. (BUTLER, 2008) 
A transição de gênero, como conceitua Giffin (2002), colocou em xeque o padrão tradicional do homem como provedor da casa, designando novos papéis sociais para homens e mulheres. Como era de se imaginar, tal transição de gênero provocou alterações profundas na constituição da identidade das mulheres exigindo novas formas de relacionamento, que, por sua vez, devem lidar com a persistência de uma cultura falocêntrica. (BUTLER, 2008) Do mesmo modo, depois do reconhecimento de que o gênero (inclui-se aqui também, a classe e a raça) é social e historicamente construído, as mulheres passaram a ter que lidar com o fato de que não existe naturalmente um "ser mulher". Como afirmou Haraway (2000), as mulheres descobrem que se tratam elas próprias de uma categoria altamente complexa, resultado de discursos científicos sexuais e de outras práticas sociais questionáveis.

O preço que foi pago para a consciência de gênero foi a clareza da terrível experiência histórica das realidades sociais contraditórias do capitalismo e do patriarcado, dentre elas, a da imposição de submissão e a violência contra as mulheres.

O reconhecimento da gravidade e dos índices da violência contra a mulher exigem estratégias de combate, sobretudo, no que diz respeito ao cuidado à saúde dessas mulheres. No Brasil, embora haja grande preocupação de diversos setores da sociedade, as iniciativas de combate ainda são tímidas ou ineficazes. Segundo dados da OMS, esse tipo de violência ocupa a 7. - posição no contexto dos 84 países do mundo, com uma taxa de 4,4 homicídios em cada 100 mil mulheres, tendo como referência o período de 2006 a 2010. O Ceará ocupa a 21. a colocação no ranking dos estados do país referente a homicídios femininos, com uma taxa de 3,4 homicídios em cada 100 mil mulheres. (WAISELFISZ, 2012)
As estratégias brasileiras de enfrentamento da violência doméstica na saúde tiveram início a partir da implantação, entre 1989 e 1990, de um primeiro serviço de saúde que realizava o aborto nas situações de estupro e risco de vida para a mãe. Assim, o problema incorporou-se à saúde e deu visibilidade a esse campo por sua delimitação de violência do tipo sexual e cometida por estranhos. (D`OLIVEIRA et al., 2009)

Em 2009, a notificação da Violência Doméstica, Sexual e/ou outras Violências foi implantada no SINAN (Sistema de Informação de Agravos de Notificação), do Ministério da Saúde, devendo ser realizada de forma universal, contínua e compulsória nas situações de violências envolvendo crianças, adolescentes, mulheres e idosos. Essa notificação é realizada pelo profissional de saúde do SUS, mediante o preenchimento de uma Ficha de Notificação específica, diante de suspeita de ocorrência de situação de violência. (WAISELFISZ, 2012)

A relevância dada ao problema da violência doméstica também surgiu como uma necessidade a ser enfrentada devido às ações do Movimento Feminista, principalmente a partir de 1970, com maior visibilidade à questão no Brasil. Logo foi possível entender que a violência contra a mulher era um problema social e histórico que não poderia ser estudado fora do contexto da sociedade que a produziu, visto que é organizada a partir dos fatores políticos, econômicos e culturais traduzidos nas relações cotidianas que, por serem construídos por determinada sociedade, podem ser por ela desconstruídos e superados. (SOUZA, 1999)

Dessa forma, desvelar a violência nos diferentes espaços de atuação das mulheres torna-se necessário e desafiador, quando consideramos o cuidado integral à saúde das mesmas. A compreensão de que a violência 
é construída em diferentes contextos sociopolíticos apresenta-nos a importância de uma prática assistencial adequada e intersetorial que possibilite revelar novas formas de cuidado integral.

Seguindo a reflexão acerca da violência contra a mulher, aliada às questões de gênero, Maia (2007) assinala que é preciso escapar do determinismo biológico, o qual parte do pressuposto de que existiria algo fixo e imutável na posição das mulheres, como se houvesse uma essência feminina, "uma verdade trans-histórica" (p.103), o que nos obriga a considerar as condições discursivas e institucionais em que certas diferenças biológicas e corporais tornaramse a característica principal do sexo.

Butler (2008) nos leva a considerar que a categoria "mulheres" não deve ser vista como imutável e permanente, de forma que também não podemos reduzir sua leitura a uma única maneira/um único ponto de vista. Nessa perspectiva de análise, entende-se que é impossível separar a noção de gênero das interseções políticas e culturais em que invariavelmente ela é produzida e mantida. Mais ainda, é preciso libertar a teoria feminista da necessidade de construir uma base única e permanente, incontestável pelas posições de identidade tradicionais para almejar uma política feminista "que tome a construção variável da identidade como um pré-requisito metodológico e normativo, senão como um objetivo político." (BUTLER, 2008, p.23)

A proposição defendida por Butler, de que a identidade não deve ser concebida de modo permanente e estável, o que denotaria a ideia de cristalização da identidade, possibilita, inclusive, aproximar as concepções feministas acerca de gênero das contribuições trazidas por Ciampa (2005), de que a identidade humana é constitutivamente social, logo, sujeita às mudanças vividas pela estrutura social vigente. Principalmente porque, para ele, "a questão da identidade deve ser vista não como questão apenas científica, nem meramente acadêmica: mas sobretudo como uma questão social, uma questão política." (CIAMPA, 2005, p.127)

Em sua concepção, identidade humana "é construção, reconstrução e desconstrução constantes, no dia-a-dia do convívio social, na multiplicidade das experiências vividas." (KOLYNIAK; CIAMPA, 1993, p.09) Expressa-se empiricamente através de personagens e a articulação dessas personagens irá compor a identidade do indivíduo. Essa leitura possibilita que avancemos na concepção de que a violência de gênero tem se conformado como uma persistência da configuração de relacionamentos ultrapassados, nos quais a mulher era vista como inferior, e procuremos entender como tem se configurado o constante processo de metamorfose da identidade, que por sua vez, sugere que existam personagens anteriores e posteriores à violência doméstica.

Ciampa (2005) procura demonstrar que a busca por transformação e, principalmente, por emancipação é uma luta por reconhecimento que, por sua vez, depende de condições históricas e sociais dadas. Propõe a mudança do sujeito através da transformação de sua identidade, compreendendo sua relação indivíduo-sociedade. Segundo ele, identidade é metamorfose humana em busca de emancipação, que nem sempre tem se concretizado por conta dos mecanismos tradicionais de administração da sociedade.

Frente aos elementos apresentados, considerando a complexidade do fenômeno da violência contra mulheres e o lugar que ocupa em uma rede de violência maior ou estrutural, não podemos perder de vista a interseção de tal fenômeno com outros fatores determinantes, tais como classe social, nível de escolaridade e representações sociais 
para citar alguns. Neste sentido, perguntamos: quais são as personagens que surgem e que se repõem nos casos de violência doméstica? Seriam novas personagens ou apenas uma reposição. Quais elementos ou conteúdos poderiam ser relevantes para que elas identifiquem, nomeiem ou dêem visibilidade às agressões que vivem em seus relacionamentos? Quais os fatores sociais, culturais e econômicos envolvidos nas suas histórias de violência doméstica?

O objetivo geral deste estudo visou compreender as transformações identitárias de mulheres vítimas de violência doméstica que procuraram um Centro de Saúde da Família como lugar de acolhimento.

\section{Metodologia}

O presente estudo teve como cenário o Centro de Saúde da Família Maria Eglantine, do bairro Dom Expedito em Sobral/CE. Tomando como referência o período de julho de 2013 a fevereiro de 2014, foram coletadas quatro entrevistas de história de vida, das quais duas foram escolhidas para análise e discussão neste trabalho.

Os sujeitos elencados para as entrevistas foram mulheres que vivenciaram violência doméstica em seus relacionamentos e que estavam sendo acompanhadas pelo Centro de Saúde da Família. Essas mulheres foram convidadas diretamente pela pesquisadora, para participar da pesquisa, a partir do contato e do vínculo previamente estabelecido entre ambas.

A escolha do tema e do lócus de investigação foi feita considerando a significativa parcela de mulheres vítimas de violência doméstica residentes nesse território e as vivências da formação em serviço, a partir do Programa de Residência Multiprofissional em Saúde da Família, experienciadas pela autora principal.

Neste contexto, sempre esteve latente nas atividades que eram desenvolvidas com mulheres, a vivência de relações violentas por parte das mesmas. Um adoecimento associado a vários tipos de violências que era, muitas vezes, sutil e imperceptível por profissionais de saúde, nos soava como disparador para questionamentos e ações.

Seguimos a proposta de pesquisa qualitativa com enfoque fenomenológico-hermenêutico, com base nas abordagens compreensivas de pesquisa em saúde. Minayo (2007) ressalta que o foco dessas abordagens está na realidade vivida, experienciada e na complexidade existente nas relações humanas.

Com relação à pesquisa empírica, utilizamos a narrativa de história de vida, por concebê-la como um gênero da pesquisa sociolinguística, já que seu corpus se dá permeado pelas narrativas. Esse tipo de pesquisa qualitativa é definida como "o relato de um narrador sobre sua existência através do tempo, tentando reconstituir os acontecimentos que vivenciou e transmitir a experiência que adquiriu." (QUEIROZ, 1988, p.20) Justificamos a escolha por esse tipo de instrumento de pesquisa tendo em vista o potencial que as narrativas de história de vida nos oferecem para mostrar como a identidade de uma pessoa foi se metamorfoseando ao longo dos anos, a partir de uma variedade de influências e ações sociais. Como assinala Lima (2009, p.41), a partir das narrativas é possível vislumbrar como "os eventos não só acontecem por conta de todas as coisas que o indivíduo vive, mas sim, por conta de determinados acontecimentos e dos significados que estes adquiriram no decorrer do tempo". 
Para a realização de uma pesquisa dessa natureza, portanto, fizemos a articulação das narrativas com outras fontes de informação que foram obtidas por meio de pesquisa bibliográfica e estudo de documentos governamentais e legislativos, utilizados como fonte de informações basilares, permitindo-nos algumas inferências acerca do tema em questão.

Com a coleta das narrativas de história de vida, foi possível registrarmos a memória viva das mulheres e compreender, igualmente, as metamorfoses que foram acontecendo nos diversos setores de suas vidas, novos significados que passaram a atribuir aos fatos de suas vidas; como se percebem e, como são vistas pelos membros dos grupos que frequentam, assim como o que mudou nas esferas familiar, social e profissional, em decorrência da violência sofrida.

\section{Análise e discussão de dados}

Os relatos autobiográficos compartilhados neste trabalho trazem as histórias de duas mulheres, aqui chamadas de Isis e Ágata, de forma a proteger suas reais identidades; bem como salientamos trocar os nomes de todos os personagens envolvidos em suas histórias. São relatos que foram difíceis de serem ouvidos, escritos e lidos. Denunciam o sofrimento, a violência, a exclusão social e o grito silenciado por uma sociedade desigual e misógina. Trouxeram à tona o conceito de pesquisador e "testemunha" apontado por Gagnebin (2006, p.57), onde o pesquisador está como aquele que compartilha o sofrimento do outro, "que consegue ouvir a narração insuportável do outro e que aceita que suas palavras levem adiante, como num revezamento, a história do outro [...]."
- A história de Isis

O contato inicial com Isis ocorreu por solicitação de uma enfermeira do Centro de Saúde, preocupada com a gestante que não estava realizando consultas de pré-natal e havia apresentado perda de líquido devido às agressões do marido. Acompanhada da agente comunitária de saúde, fomos até a casa de Isis e a encontramos sentada à porta da casa de taipa, de três cômodos. Após alguns encontros, a convidamos para fazer parte da pesquisa. Na ocasião da entrevista, conversamos na porta de sua casa, sentadas na calçada, com o marido e o filho mais velho.

Tenho 35 anos. Moro aqui com este aí (aponta referindo-se ao marido) e mais um menino e uma menina. Agora tem este outro aqui (passa a mão pela barriga, sugerindo a gestação de quatro meses).

Para dizer quem é, Isis começa apresentando sua família, o marido e os filhos. Em seguida, começa a falar de onde veio e de sua família.

Eu nasci no sertão, minha mãe morreu, eu nem conhecia. Aí fui morar com minha avó, né?! Aí, quando ela morreu fui morar com a minha irmã, aí vim pra cá pra Sobral. Meu pai morava bem ali assim... (aponta para a casa amarela a poucos metros dali) [...] Minha irmã era ruim demais, saía e me deixava só em casa com os menino dela e eu tinha que cuidar da casa também. Fui criada sem pai nem mãe, bolando por aí. Bolei muito de casa em casa. Trabalhava em casa de família. Fui até pra Fortaleza. A mulher num me dava um tostão, mandava tudo pro meu pai aqui. Aí eu pedi pra voltar. Aí quando tinha treze anos conheci o "João" (atual marido) e fugi com ele. Ora se eu queria ficar cuidando de filho dos outros?! 
Teve a infância marcada pelas ausências familiares, a desconstrução dos laços afetivos e pelo trabalho. Frequentou pouco a escola, estudou até a segunda série do Ensino Fundamental I. Não tinha casa, morava "com um e com outro" e trabalhou como doméstica desde criança.

Vim morar nessa casa depois que o meu pai morreu. Ele morreu de câncer. Era muito ruim, batia muito na gente, judiava mesmo. Não podia falar com ninguém, nem sair, tudo ele batia. E ele bebia muito. Meus irmãos tudim bebem. Tem uns que bebe mais pouco. Minha mãe morreu com coração crescido. Eu era muito pequena, nem lembro dela.

Descreve o pai como violento e alcoolista, bem como os irmãos. Testemunha da violência e do alcoolismo, do pai e dos irmãos, tende a reproduzir em seus relacionamentos tais comportamentos, num ciclo perverso de violência e exclusão. Martins e Ferriani (2008), numa análise dos ciclos da violência, atentam para o fato de que tais vivências na infância trazem a violência como um aprendizado que será imitado na fase adulta, no que chamam de multigeracionalidade. Voltando a sua história, Isis nos fala o que sente em relação à mãe.

Tenho raiva da minha mãe que morreu me deixou aqui só. Se ela fosse viva era diferente. Acho que eu não ia viver nessa vida difícil. Não ia ter sofrido tanto, não ia ter ficado tão só. Não tenho ninguém pra me dá um conselho. Só tem gente pra criticar, esculhambar a gente.

Não possui lembranças da mãe, apesar de referirse a ela com certo rancor. Perdendo a mãe e a avó, não encontrou na irmã o afeto que esperava. Acredita que a presença da mãe a teria feito melhor e diminuiria seu sofrimento, principalmente no que se refere a não ter um lar, "ficar bolando de casa em casa". Conheceu o marido aos 13 anos e nele enxergou a possibilidade de ter uma família e um lar.

Meu marido é doido desse jeito aí, bebe, usa as coisas dele, vende as coisas de casa pra comprar droga, mas eu só tenho ele. Num tenho família, nem ninguém. Só quem me ajuda mais é a mãe dele. Mas tem que fazer os querer dela. (risos) Ela fica com raiva quando eu bebo. Não quer que eu beba. Ela tá certa, mas não me controlo. Ela quem me dá coisa de casa, comida, esta televisão, este fogão, este guarda-roupa. Eu esculhambo ela quando tô bêbada, mas ela é boa.

Encontra o referencial de família que procurava. Tem uma casa, móveis, uma sogra, um marido e filhos. A menina que cresceu "sem ter ninguém" encontra alguém e uma família que a acolhe, provém e preocupa-se. Entretanto, aponta o uso abusivo do álcool como uma problemática familiar.

Antigamente eu não bebia. Na época que me juntei mais ele eu não bebia. Quando ele (marido) colocou o bar, saia e me deixava só. Aí eu bebia com o pessoal e me viciei. Quando passo um dia sem beber é ruim demais. Minhas carne ficam tudo tremendo, fico com uma "desimpaciência" dentro de casa, brigando com os meninos e com ele aí. Agora é que tentando parar mais por causa da barriga. No começo eu fiquei triste, depois de quinze anos você pegar um bucho num é fácil. Mas agora tá melhor, eu quero cuidar do meu filho. 
Isis fala de si no presente, aliando histórias do passado. O exercício de falar de si e contar a própria história refletindo sobre o passado, parece doloroso, pois a remete à tentativa de esboçar uma outra história e inventar o presente. Grávida, a vida parece renovar-se, apesar do vício e das dificuldades financeiras que enfrenta. Traz a possibilidade de repensar aquilo que é e que poderia ser, buscando novos projetos de identidade. É este elemento que caracteriza a identidade enquanto movimento e possibilidades. (LIMA, 2009)

O desconforto relacionado aos sintomas da abstinência acabava como uma motivação para beber novamente. Em relação aos comprometimentos sociais decorrentes do consumo alcoólico, Nóbrega e Oliveira (2005) destacam que o uso abusivo de bebidas alcoólicas na família acaba desencadeando agressões físicas e verbais no contexto familiar. Fato evidenciado pelo relato de Isis:

Quando tô assim sem beber, qualquer coisinha me zango, começo uma briga aí ele vem pra cima de mim e eu pra cima dele. $\mathrm{E}$ nós bate um no outro mesmo. Até que alguém chama o Ronda e ele sai correndo. O Ronda nem vem mais porque num adianta. O policial fez foi dizer que num vinha mais não porque nós num parava de brigar e depois eu queria ir lá na delegacia buscar ele.

A violência vivida por Isis ganha mais sentido quando consideramos os problemas sociais vivenciados pela família. Uso abusivo de álcool e outras drogas, dificuldades financeiras e a impunidade. Traz no seu relato as contradições da sociedade, do mal-estar cotidiano de viver com o mínimo. Além disso, reflete as limitações da aplicação da lei Maria da Penha, em vigor desde 2006, que tem por objetivo coibir a violência doméstica e familiar contra a mulher.

Considerando que o espaço de produção da violência de gênero possui caráter relacional, ou seja, é um fenômeno social produzido no contexto de densas relações de poder, entende-se que esse tipo de violência não pode ter seu enfrentamento reduzido ao tratamento dos sujeitos nela implicados. Antes, deve ser compreendido como uma das expressões das desigualdades sociais que fecundam também, diversamente, a classe social e o gênero.

Isis termina o relato de sua história inacabada refletindo a angústia do futuro incerto.

Às vezes, quando tô só, penso em tanta coisa. A vida podia ser diferente. Às vezes penso em me matar. Tenho raiva dessa vida difícil. Às vezes, penso em pegar a bicicleta e sair sem rumo e não voltar [...]

Traz no relato humor deprimido, desejo de mudança de vida. Morrer, sair sem rumo, qualquer coisa que faça com que algo aconteça. Na multiplicidade de experiências que teve desconstrói-se e reconstrói-se novamente em personagens: "menina órfã de mãe", "órfã de avó", "filha sem pai nem mãe", "mulher sem lar", "alcoolista", "mãe", "esposa", "gestante", "doméstica", "dona de casa"- metamorfoseia-se e transforma-se. Mas esta construção identitária não se dá de forma isolada. A identidade só realiza-se na relação com o outro, visto que são as relações sociais que concretizam a identidade de cada ser humano; identidade não apenas é influenciada pelo social, ela é constitutivamente social. (CIAMPA, 2005) Assim, a identidade não pode ser pensada em si mesma, mas na dialética das relações do indivíduo consigo mesmo, com os outros e com a sociedade. 


\section{- A história de Ágata}

Conhecemos Ágata no grupo de convivência de idosos. Conversávamos sobre o dia mundial de combate à violência contra a mulher, quando Ágata, "viúva e mãe de quatro filhos", decidiu dar seu depoimento e nos falou sobre a violência que sofreu por vinte e três anos por parte do falecido esposo.

Encontramo-nos depois, em sua casa, para a entrevista. Bem-humorada, começou a relatar sua história revelando quando e onde nasceu.

Eu nasci em doze do onze de mil novecentos e trinta e nove, na Meruoca. Somos quatro irmãos, duas mulheres e dois homens. Não cresci mesmo na Meruoca, era mais pra cá, no sítio São Braz que eu nasci. Viemos pra cá pra Sobral eu tinha sete anos. A mamãe era muito da casa da família Sabóia, que eram donos da fábrica de tecidos, sabe? E aí chamou a mamãe pra cá pra poder trabalhar, minha mãe e o meu pai. Aí a gente veio "simbora" pra cá, pra Sobral.

E continuou apresentando a família e as atividades laborais que desenvolviam.

Aí de lá minha mãe ficou trabalhando. Meu pai saiu (da fábrica de tecidos) e minha ficou até se aposentar. Aí depois meu irmão entrou na fábrica. E eu entrei com treze anos também. [...] E lá eu trabalhei por 50 anos ao todo, né? Só sai porque a fábrica acabou-se.

Trouxe, no relato, aproximação com o trabalho desde muito cedo. Revelando-o como parte essencial para sua existência e definidora daquilo que é: "trabalhadora". Continuou, assim, falando da infância e do trabalho.
Infância era só de trabalho. Naquela época, sabe como é, né? Não tinha diversão [...] Estudei muito pouco. Só até o terceiro primário. Comecei a trabalhar na fábrica muito cedo e antes eu trabalhava em casa, fazendo chapéu, camisa de garrafa. Foi nisso que eu levei minha vida. Parei de trabalhar em 2003. Desde cedo, a gente tava vendo que a mamãe e o papai não tinha muita responsabilidade, daí a gente viu que precisava trabalhar [...]. Meu pai não tinha responsabilidade de botar as coisas dentro de casa. Num perseverava num emprego [...] minha mãe era que assumia. Na família, antes de eu casar, era tranquila [...] minha mãe era muito boa, muito boa mesmo. Eu adorava meus irmãos.

Ainda trazendo o trabalho como fator preponderante para a família, Ágata nos informou que os pais "não tinham responsabilidade", sendo o pai alcoolista, e que junto com a mãe e os irmãos assumiam as despesas financeiras da casa. Nóbrega e Oliveira (2005) ressaltam que o trabalho, para a mulher, possui uma representação social diferente em comparação ao homem, trazendo como fatores importantes nesse contexto: a dupla jornada de trabalho, o não reconhecimento social, a complementaridade da renda familiar e a incorporação subjetivada ao desemprego, como uma questão estrutural e não apenas conjuntural em suas vidas.

É interessante atentar também, para a construção histórica das diferentes concepções de família e a influência disto nos papéis estabelecidos por cada membro. $\mathrm{Na}$ atualidade, o desempenho desses papéis pode encontrarse instável e indefinido. O domínio masculino ainda constitui atributo básico, numa forma de poder hierárquica 
e autoritária, mesmo quando o homem deixa de ser o único provedor da casa.

Seguindo a história de Ágata, ela nos falou como conheceu o marido e a trajetória de seus relacionamentos.

[...] eu só botei três namorados na minha porta. Este primeiro durou quatro anos, teve outro que durou nove anos e este meu marido. Meu desejo era ter me casado nova. Deixei o de nove anos pra me casar com este aí. Taí, pulando de galho em galho, aconteceu isso! [...]

Contou-nos, com riqueza de detalhes, como conheceu o esposo, trazendo esse período da vida como crucial para o desenrolar de sua história.

Passei vinte e três anos casada [...] Ele era motorista do carro do lixo quando conheci. Eu era noiva e ele era noivo também, com uma enfermeira. Olha as coisas como tem que ser? [...] Ele deu pra passar aqui na rua. Ele nem pegava lixo aqui, mas começou a passar. Quando ele vinha, que eu percebia que era o carro do lixo eu me escondia e ficava vendo ele pelo buraco da porta. [...] Ele dobrava assim, eu não sabia que ele olhava pelo retrovisor. (risos) Aí ele mandou o recado pra mim, que queria falar comigo. E eu, noiva e ele também!

Conforme explica, decidiu então terminar o antigo relacionamento para casar-se com "Chico".

Eu fui me abusando do outro, olha?! o outro era pontual, era assim uma pessoa, sabe como é uma pessoa muito correta? Nunca ouvia falar dele com nada, nem com bebedeira nem nada. Mas mulher num é bicho sem vergonha, né? Só quer o que não é pra ser! Com mais de nove anos de namoro, um dia ele chegou aqui de tarde e eu fui e disse que não queria mais não. Eu queria era casar e não viver minha vida namorando. Eu já ia fazer 30 anos! Ora se eu já tava indo falar com outro! Eu sei que nós namoramos nove meses e casamos.

Salientou, no relato, os papéis socialmente construídos para o feminino e o masculino. E apontou diferenças de gênero e papéis sociais. Sua fala remete-nos às reflexões de Scott (1990), de que a construção de gênero tem por base as relações sociais e as diferenças percebidas entre os sexos e, por sua vez, constituem-se no interior de relações de poder. Para a autora, gênero não reflete ou implementa diferenças fixas e naturais entre homens e mulheres, mas sim reflete os significados dessas diferenças corporais. O que a autora propõe é uma análise sobre "como as hierarquias de gênero são construídas, legitimadas, contestadas e mantidas" (p.14). Ela observa que é preciso analisar os significados "variáveis e contraditórios" que são atribuídos à diferença sexual, e que é preciso perceber em quais contextos políticos os significados dessa diferença são criados.

Ágata, criança obediente, mulher trabalhadora, alimentava o desejo de tornar-se mulher casada e, assim, o concretizou.

Ele só foi assim, legalzinho, até seis dias. Nós casamos e ficamos mesmo aqui em casa, com a mamãe. Ele chegava aqui em casa bêbado, bagunçando, botando boneco, sabe? [...] Cismava muito com minha mãe até que ela foi morar em Brasília com minha irmã. Minha mãe foi e eu fiquei pagando o pato sozinha. Sofri que só! [...] Chegava em casa querendo me açoitar e muitas vezes eu corri pra 
casa dos vizinhos. Ele ia atrás, bagunçava. Me levava de novo pra casa. Era tanta "fuleragem" que ele fazia.

Parece perceber o casamento como o início do seu sofrimento, mesmo que na infância já tivesse que conviver com a "irresponsabilidade dos pais" e a exploração do trabalho infantil.

Seguindo a história, a mãe vai embora e Ágata encontra-se sozinha "pagando o pato".

Ele ia atrás de mim todo tempo, me perseguindo, me esculhambando de caminho a fora. Eu chegava dentro da fábrica e dava graças a Deus quando colocava o pé dentro da portaria! Eu já tava tão assim por tudo! [...] Uma vez eu chamei o gerente pra ir mais eu na delegacia porque eles podiam achar que eu era uma vagabunda, uma mulher qualquer, tá entendendo? Ele foi pra dizer quem eu era, pra ver se o delegado demorava mais com ele preso lá. O delegado foi e disse, olhe a gente não pode prender. Com negócio de casal a gente não pode se meter porque a gente briga, prende e quando for mais tarde eles tão bem, alegres e satisfeitos e a gente é quem fica marcado. É melhor você num se meter. Aí pronto, depois disso eu não chamei mais ninguém e penei muito.

A vítima resignada pela escolha que fez ao casar com Chico procurou ajuda na fábrica e na Delegacia. Resignouse e, ao mesmo tempo, não desistiu. Buscou a intervenção daqueles os quais considerava "autoridades", para cessar a violência, sentir-se mais segura e legitimar seu sentimento de injustiça. Entretanto, o socorro foi silenciado pela impunidade e pela cultura hegemonicamente machista.
Antes de existir uma legislação penal específica que cuidasse da violência doméstica e familiar contra as mulheres, eram aplicadas as normas incriminadoras do Código Penal. Entretanto, pelo relato de vida de Ágata, nem mesmo essa prática era considerada para casos envolvendo violência contra a mulher.

Sem apoio "das autoridades", Ágata decidiu lutar sozinha. Era a "filha obediente", "esposa obediente" começando a transformar-se e dar vida a uma nova personagem, trata-se da "superação da personagem reposta pelo indivíduo.” (LIMA, 2009, p.164)

[...] um dia lá dentro (na fábrica), conversando com as meninas que vendiam batom e perfume eu fui botei um batom pra experimentar, né?! Quando eu cheguei, [...] ele foi e disse: "Ih batom, né? Tá namorando?" e começou a me chamar de nome e veio me açoitar. Os meninos gritavam, se agarravam em mim. Meu Deus, não gosto nem de lembrar! Passou. Quando foi no outro dia, eu pensei assim: "vou comprar essa briga! [...] Tinha apanhado muito no dia antes. Quando foi na hora de sair do trabalho eu tornei a me pintar. Fui lá na oficina e mandei fazer uma faquinha. [...] Eu cheguei aqui, não demorou nada lá vem ele de novo me açoitar, num sabe?! E eu disse "vem"! Porque sei lá, acho que a gente também tem instinto de gente ruim. Na hora puxei a faca assim e furei ele."

$\mathrm{O}$ ato de coragem de Ágata repercutiu não apenas na relação do casal, mas na forma como ela percebia-se nessa relação e nos significados que atribuiu a esses fatos. 
[...] depois dessa furada ele melhorou mais. Quando ele queria vim pra cima de mim eu enfrentava e dizia: "vem!" [...] Tudo tem o seu limite, a gente sofre. Tem vez que a pessoa faz as coisas com os outros não é porque seja ruim, é porque chega o limite, chega o final. Você aguentar vinte e tantos anos uma pessoa todo tempo ali judiando. Você só trabalhar pra dá de comer, de vestir, pra dá tudo aos filhos, quatro filhos e a cunhada que vivia dentro de casa! Muitas vezes ele chegava de madrugada e ela agarrava ele enquanto eu corria com medo pra casa dos vizinhos. E eu fui criando uma revolta de viver numa vida tão sufocada daquela.

A identidade de Ágata estava em movimento e transformação. Afirmou ter chegado no final, no limite. Os fatos que se sucederam refletem essa mudança de comportamento diante da relação violenta na qual estava inserida. Decidiu colocá-lo para fora de casa e enfrentar o medo. Mas a metamorfose ainda não estava completa, apesar de a realidade ter começado a ser interpretada de forma diferente.

Eu cheguei e disse "a partir de hoje você não entra mais nessa casa, pode ir embora!" Bati as portas, fiquei zangada, assombrada. Eu vivia assombrada. [...] Foi uma confusão danada! Muito ruim a gente ter uma vida desmantelada! [...] Com poucos dias que tinha mandado ele embora, a barriga dele começou a inchar. Ele chegou pedindo "pelo amor de Deus, me deixe aqui. Tô doente, eu vou morrer." Aí me deu aquela pena, sabe?! Ele estava pedindo com tanta piedade [...] ele tava amarelo, com a barrigona, aí eu deixei. [...] Quando foi de noite, levei lá na Santa
Casa e o médico olhou e disse que ele tava com a cirrose hepática. Internou ele e com poucos dias ele morreu. Eu pensava que ele um dia melhorava. A minha paciência era que um dia ele ia melhorar. Era isso que eu pensava. Às vezes eu pensava em me separar, mas tinha medo de ele ficar atrás de mim, me perturbar. [...]. Às vezes eu pegava minhas roupas e ia dormir na casa do meu irmão, mas no outro dia ele ia atrás e lá vinha eu de novo. Eu não podia abandonar minha casa. Pra onde eu ia com quatro filhos? Não dava. O jeito era viver nessa vida.

O fato de ter acolhido novamente seu agressor em casa parece ter sido um ato de compaixão e solidariedade. Mas, também demonstra a esperança de mudança no comportamento do marido. Ainda preserva em sua identidade a "mulher-esposa", "mãe", "cuidadora", "trabalhadora". A afirmação da identidade e a demarcação da diferença implicam sempre em incluir e excluir. Isto conduz a uma inevitável separação que indica as posições dos sujeitos nas relações sociais. Ao separá-los, eles são classificados e hierarquizados. Acabamos, portanto, atribuindo-Ihes valores diferenciados e elegendo apenas determinadas identidades como parâmetro a ser seguido socialmente.

Quando normalizamos uma identidade dessa maneira, permitimos que se torne natural e desejável. Atribuímos a ela características positivas e negamos as demais identidades. A identidade e a diferença estão estreitamente associadas a sistemas de representação, pois, através desses sistemas, adquirem sentido. "Quem tem o poder de representar tem o poder de definir e determinar a identidade." (SILVA, 2009, p.91) Este é o motivo pelo qual questionar a identidade e a diferença significa questionar também as formas de representação que lhes sustentam. 
Uma identidade expressa uma articulação dinâmica de representações, posições e papéis experimentados em diferentes contextos e situações. Simultaneamente, à medida que "o indivíduo não é algo, mas sim o que faz, o fazer é sempre atividade no mundo, em relação com os outros." (CIAMPA, 2005, p.137) Assim, a identidade não pode ser pensada em si mesma, mas na dialética das relações do indivíduo consigo mesmo, com os outros e com a sociedade.

Ágata construiu personagens e correspondeu às representações identitárias socialmente esperadas. Mas o fato de interiorizarmos aquilo que os outros nos atribuem torna-se algo nosso?

Após a morte do marido salienta que, hoje, tem uma vida tranquila.

[...] Quando ele morreu acabou meu desassossego. O pessoal chegava no enterro e dizia "a viúva nem chora?" . Eu ia chorar o quê? Já tinha chorado tudo a vida inteira. Não tinha nada pra chorar. Hoje eu tô bem, ele era aposentado e fiquei com a pensão dele. [...] Com minha aposentaria e a pensão dele, aí pronto deu pra viver sossegada [...]

As personagens são momentos em nossa história de vida e a articulação dessas constitui nossa identidade. O indivíduo não apenas recebe e incorpora as predicações sociais, mas também propõe novas personagens e se autodetermina. Essas transformações do sujeito e de sua identidade demonstram a busca do ser humano por mudanças e por emancipação, apesar dos mecanismos tradicionais de administração e manutenção da sociedade. (CIAMPA, 2005)
Ágata teve a trajetória de vida marcada por exigências sociais tradicionais e patriarcalistas. Guarda a lembrança da "mãe muito boa" que cuidava da casa, dos filhos e cuidou do marido até a morte. Tem a memória do pai "irresponsável e alcoolista", mas que não chegava em casa bagunçando. Recebeu do delegado a resposta dada a tantas outras mulheres violentadas: "É assim mesmo, melhor não se meter em briga de casal. Logo estão juntos, alegres e satisfeitos". Na mesmice, realizava a reposição constante da representação "esposa-mãe-trabalhadora", concretizando aquilo que Ciampa (2005) traz como fetichismo da personagem, ou seja, o indivíduo não atinge a condição de "ser-para-si" (busca pela autodeterminação), cria a chamada identidade-mito e permanece, portanto, no mundo da mesmice, com a falsa impressão de que não existem determinações exteriores em seu comportamento.

Ágata não permaneceu apenas na mesmice, embora sua identidade tenha-se apresentado de maneira estática, disfarçando sua dinâmica real de permanentes transformações e de (re)posições. Mas essas (re) posições não foram as mesmas, as condições objetivas foram diferentes, outros significados surgiram e foram internalizados mesmo que imperceptíveis, pois, como matéria, estamos em constante transformação.

\section{Considerações finais}

Nas histórias de vida trazidas neste trabalho nos foi possível perceber que as questões de identidade e gênero são influenciadas pelas condições históricas, sociais e materiais dadas, bem como pelas condições do próprio indivíduo. 
As violências por elas vivenciadas refletem não apenas o sofrimento, mas também o desamparo. Ambas procuraram por intervenção policial, em momentos históricos diferentes, e receberam respostas negativas do Estado. O despreparo dos policiais, a visão estereotipada da mulher que denuncia, o desconhecimento das questões de gênero, bem como a estrutura autoritária da própria polícia enquanto corporação, dificultam a implementação e execução de leis como a Lei Maria da Penha.

Além disso, ainda convivemos com políticas públicas rasas e inconsistentes no que se refere ao acolhimento e cuidado dessas famílias nos serviços de saúde. Oliveira, corrobora com esta percepção e acrescenta:

[...] a violência tem sido responsável por uma demanda crescente de atendimentos nos serviços de saúde [...], porém os trabalhadores da saúde não a percebem como situação merecedora de cuidado e acolhimento. É como se a violência estivesse fora de seu campo de intervenção. (Oliveira, 2007, p.44)

Não estando em seu campo de atuação, o sofrimento ocasionado pela violência doméstica não é considerado pelos profissionais de saúde, mesmo que seja visto.

Bispo (2012), em recente estudo realizado em Sobral/ $\mathrm{CE}$, analisa a produção do cuidado de enfermeiros e agentes comunitários de saúde da Estratégia Saúde da Família dessa cidade, às mulheres vítimas de violência intrafamiliar e desvela as dificuldades referentes ao acolhimento e cuidado dispensado a elas. Traz como desafios a falta de estrutura física e de organização de serviços de saúde; a falta de capacitação dos profissionais para lidar com vítimas de violência; a dificuldade em realizar uma escuta qualificada devido à excessiva demanda dos Centros de
Saúde da Família; todos esses aspectos atrelados à sensação de indignação, impotência e um sentimento de frustração agravado por barreiras como a falta de orientação ou apoio sobre o que realmente podem fazer no combate à violência contra a mulher.

Sendo a violência um fenômeno sócio-histórico e cultural, portanto, construído, é passível de intervenção. Entendemos que pensar a violência como um fenômeno social implica conhecer sua caminhada histórica, o que coloca os profissionais de saúde diante de possibilidades de intervenção acerca do fenômeno. Sabemos que muitos casos de violência não são comunicados, nem chegam a existir sob a ótica da esfera jurídica, e que ainda temos entraves éticos. Vários profissionais preferem não se envolver nesse tipo de situação, culturalmente entendida como um problema do casal, o que dificulta a possibilidade de qualquer intervenção.

Dados epidemiológicos são importantes para detecção, planejamento, execução e avaliação de ações e políticas de saúde voltadas ao atendimento de mulheres que vivenciam situações de violência doméstica. Mas a notificação não pode ser encarada como a última ação para os profissionais de saúde e sim como algo fundamental para assegurar a continuidade do atendimento àquela família.

Entretanto, apesar da notificação ser prevista em lei, muitos profissionais não notificam os eventos violentos à vigilância epidemiológica pelo medo de o agressor descobrir quem os notificou e direcionar-lhes alguma violência, além do fato de os serviços de saúde locais não oferecerem nenhum tipo de segurança ao profissional, o que o coloca em uma situação de exposição e medo, visto que o sigilo da notificação por vezes é violado. (CAVALCANTE, 2013) No desenvolvimento desta pesquisa, foi comum a recusa das mulheres em gravar suas histórias de vida. Contavam- 
nos suas histórias, narravam com riqueza de detalhes, entretanto, não nos autorizavam a utilizar o gravador. Percebíamos que a barreira do medo não havia sido quebrada e essas mulheres, que continuavam convivendo com a violência, tinham receio que o agressor fosse citado na pesquisa ou tomasse conhecimento de seu relato.

Quanto ao nosso objetivo do estudo, as narrativas violentas que testemunhamos evidenciam que identidade é metamorfose, transformaçãoemanifesta-secotidianamente na luta pela existência humana. Não esqueçamos, somos humanos! As histórias compartilhadas trouxeram registros de memórias vivas que inventam o futuro, procuram saídas para as desigualdades e possibilidades de transformação de si mesmas e do mundo.

Aprendemos muito com as histórias de Isis e Ágata, que poderiam ser histórias contadas por tantas outras mulheres. Reconhecemo-nos nelas, e, dessa maneira, encontramos algo nosso. Não porque acreditamos que exista uma identidade comum a todas as mulheres, até mesmo porque alguém ser mulher, não é tudo que esse alguém pode ser. $O$ reconhecimento também não está aqui reduzido à formulação e emissão de julgamentos sobre as vidas dessas mulheres. Na verdade, o reconhecimento, às vezes, nos obriga a suspender o julgamento, a fim de apreender o outro. Quando se julga as pessoas por serem como são, estabelece-se de forma invariável uma clara distância moral entre quem julga e quem é julgado. Somente através da experiência do outro, em condições de suspensão de julgamento, somos finalmente capazes de uma reflexão ética sobre a humanidade desse outro. (BUTLER, 2009)

Reconhecemo-nos também, nas condições de controle a que ainda estamos submetidos atualmente. Nós, seres humanos, independentemente de sexo ou gênero, precisamos pensar e criar novas formas de resistência social, e perceber os empecilhos de uma emancipação concreta. Talvez isto nos aponte novos caminhos de expressão da identidade e o alcance da emancipação. Mas, seria possível chegar à emancipação de fato? Nos construímos e desconstruímos tantas vezes, e convivemos com uma lógica tão individualista e socialmente desigual que, na maioria delas, não encontramos respostas e parece não haver saídas. Porém, não sejamos assim, tão pessimistas. As transformações parciais, como aquelas trazidas nas trajetórias de vida de Ágata e Isis, foram tentativas de mudança de vida e, como tais, válidas na busca por significados e sentidos de viver. Acreditemos na metamorfose permanente da humanidade e em novas possibilidades de existência, em uma sociedade que vislumbre uma maior equidade de gênero e a construção de masculinidades e feminilidades menos rígidas.

\section{Referências}

BUTLER, J. Problemas de gênero: Feminismo e subversão da identidade. 2ed. Rio de Janeiro: Civilização Brasileira, 2008. Trad. Renato Aguiar.

Dar cuenta de símismo. Violencia ética y responsabilidad - 1a Ed. - Buenos Aires: Amorrortu, 2009. Traducción de Horacio Pons.

CAVALCANTE, M.M.B. Violência Intrafamiliar: Um estudo sobre a produção do cuidado. Dissertação (Mestrado em Saúde da Família) - Universidade Federal do Ceará, Sobral, 2013. 
CIAMPA, A.C. A estória do Severino e a história da Severina: Um ensaio de Psicologia Social. São Paulo: Brasiliense, 2005.

FERRIANI, M.G.C. et al. Debaixo do mesmo teto - Análise sobre a violência doméstica. Goiânia: AB Editora, 2008.

GAGNEBIN, J.M. Memória, História, Testemunho. In.: GAGNEBIN, J.M. Lembrar escrever esquecer. São Paulo: Ed. 34, 2006.

GIFFIN, K. Pobreza, desigualdade e eqüidade em saúde: considerações a partir de uma perspectiva de gênero transversal. Cad. Saúde Pública, v.18, supl. Rio de Janeiro, 2002.

HARAWAY, D. Manifesto Ciborgue: ciência, tecnologia e feminismo-socialista no século XX. In.: SILVA, T.T. Antropologia do Ciborgue. Belo Horizonte: Autêntica, 2000.

WAISELFISZ, J.J. Mapa da Violência 2012. Os novos padrões da violência homicida no Brasil. São Paulo, Instituto Sangari, 2011.

KOLYNIAK,H.M.R.;CIAMPA, A.C. Corporeidadee Dramaturgia do cotidiano. Discorpo: Revista do Departamento de Educação Física e Esportes da PUC-SP. n.2 (março, 1994). São Paulo: O Departamento, 1993.

LIMA, A.F. Sofrimento de indeterminação e reconhecimento perverso: Um estudo da construção da personagem doente mental a partir do sintagma identidade-metamorfoseemancipação. Doutorado em Psicologia Social. São Paulo: PUC/SP, 2009.

MAIA, M.B. Gênero - um conceito em movimento. In, MAYORGA, Cláudia \& PRADO, Marco Aurélio Máximo. Psicologia Social: articulando saberes e fazeres. Belo Horizonte: Autêntica, 2007.
MINAYO, M.C.S. O desafio do conhecimento: pesquisa qualitativa em saúde. 10a ed. São Paulo: Hucitec, 2007.

NÓBREGA, M.P.S.S.; OLIVEIRA, E.M. Mulheres usuárias de álcool: análise qualitativa. Revista Saúde Publica, v.39, n.5, 2005. p.816-823.

OLIVEIRA, E.N. Pancada de amor dói e adoece: violência física contra mulheres. Sobral, CE. Edições UVA, 2007.

QUEIRÓZ, M.I.P. Relatos orais: do "indizível" ao "dizível". In: SIMSON, O. (Org.). Experimentos com história de vida. São Paulo: Vértice, 1988.

ROSA, J.T.; MOTTA, I.F. Violência e Sofrimento de crianças e adolescentes na perspectiva Winnicotiana. Aparecida: Idéias \& Letras, 2008.

SARTI, C.A. O feminismo brasileiro desde os anos 1970: revisitando uma trajetória. In, Revista Estudos Feministas. v.12, n.2, Florianópolis, Maio/Agosto, 2004.

SILVA, T.T. (org.) Identidade e Diferença: a perspectiva dos estudos culturais. Petrópolis: Vozes, 2009. 9ed.

SOBRAL. Coordenação da Vigilância à Saúde. Sobral, 2011.

SOUZA, E.R.; MINAYO, M.C. O impacto da violência social na saúde pública do Brasil: década 80. In MINAYO, M.C. (org.). Os muitos brasis: saúde e população na década de 80 . São Paulo-Rio de Janeiro: Hucitec-Abrasco, 1995. p.87-116.

É possível prevenir a violência? Reflexões a partir do campo da saúde pública. Ciênc. saúde coletiva. v.4, n.1, Rio de Janeiro,1999.

TELES, M.A.A.; MELO, M. O que é violência contra a mulher. São Paulo: Brasiliense, 2003. 
D'OLIVEIRA, A.F.P.L.; SCHRAIBER, L.B.; HANADA, H.; DURAND, J. Atenção integral à saúde de mulheres em situação de violência de gênero - uma alternativa para a atenção primária em saúde. Ciência \& Saúde Coletiva, v.14, n.4, p.1037-1050, 2009.

\title{
PRESERVANDO A VIDA DOS HOMENS: GRUPOS DE AUTOCUIDADO COM USUÁRIOS DE BEBIDA ALCOÓLICA
}

\author{
Gláucia Almeida Mapurunga de Paiva \\ Bráulio Nogueira de Oliveira \\ Adriano Ferreira Martins
}

\section{Introdução}

As drogas lícitas são aquelas autorizadas e legalizadas pelo Estado e, desta forma, não apresentam nenhuma restrição quanto ao consumo e uso das mesmas. (BRASIL. MINISTÉRIO DA JUSTIÇA. SECRETARIA NACIONAL DE POLÍTICAS SOBRE DROGAS, 2011) Entre essas substâncias apontamos o álcool, elemento comum na vida de milhões de pessoas em todo o mundo. Para o Ministério da Justiça, seu uso indevido é um dos principais fatores que contribui para a diminuição da saúde mundial, convergindo em transtornos de saúde física e social. (BRASIL. MINISTÉRIO DA JUSTIÇA. SECRETARIA NACIONAL ANTIDROGAS, 2007)

No Brasil, a característica do uso desse elemento, com a veiculação nos meios de comunicação de massa, cujo objetivo é o aumento de consumidores e a facilidade de acesso à droga, torna o álcool potencial fomentador de 
dependentes. (BRASIL, MINISTÉRIO DAJUSTIÇA. SECRETARIA NACIONAL DE POLÍTICAS SOBRE DROGAS, 2011)

Nessa perspectiva, o álcool continua sendo consumido em proporções relevantes, face à disseminação popular nas mais variadas facetas, do anestésico ao narcótico, e atinge todas as classes sociais e gêneros (IBGE, 2009). É esse consumo exagerado do álcool que abre oportunidades para a utilização e sua combinação com as demais drogas emergentes tornando-se um problema de denso controle e resolução.

De acordo com o último levantamento nacional, cerca de $12 \%$ de toda a população preenchiam critérios para dependência alcoólica. Esses dados corroboram com as estimativas do Ministério da Saúde de que aproximadamente $9 \%$ da população geral do país precisa de atendimento eventual de saúde mental (transtornos menos graves), dentre os quais se encontram os transtornos decorrentes do uso prejudicial de álcool e outras drogas. (VARGAS; OLIVEIRA; LUÍS, 2010)

Diante dessa problemática, registra-se a relevância da necessidade cada vez mais precoce de associar medidas e ações de prevenção ao uso de álcool dentro da Atenção Primária em Saúde (APS).

A Estratégia Saúde da Família (ESF) avança com a implementação de novas tecnologias através de inovadores e contínuos programas na APS, trazendo o desafio constante de ultrapassar o modelo assistencial biomédico e curativista que, culturalmente, ainda permeia a relação entre trabalhadores do SUS e usuários. É a partir desses programas e da organização dos níveis da atenção em saúde, dos princípios doutrinários e organizativos do SUS que se aposta no estabelecimento de vínculos e de corresponsabilidade entre profissionais e a população, bem como trabalha-se a estratégia de vigilância da saúde com atuação inter e multidisciplinar responsabilizandose pela integralidade das ações na área de abrangência. (BRASIL, MINISTÉRIO DA JUSTIÇA. MINISTÉRIO DA JUSTIÇA. SECRETARIA NACIONAL ANTIDROGAS, 2007)

As ações inter e multidisciplinares na ESF devem estar fortemente alinhadas a esse cuidado integral com as pessoas, grupos e coletividade, pois é nas ações planejadas e executadas através de profissionais de múltiplas categorias e usuários que temos a chance destes se apropriarem de sua condição de saúde e suas necessidades, numa contínua e emancipadora educação em saúde, revelando e instigando nos indivíduos autonomia e autocuidado. (MACHADO et al., 2007)

Nesse sentido e apostando ainda mais na atuação precoce da APS, o Ministério da Saúde lançou em 2008 a Política Nacional da Saúde do Homem. Esse projeto partiu do entendimento de que os homens geralmente adentram o sistema de saúde por meio da atenção especializada, em função do agravo de morbidades que poderiam ser evitáveis, pelo atraso na atenção, gerando maior custo para o SUS. Além do que, apresentam maior vulnerabilidade e altas taxas de morbimortalidade, pois não buscam, como as mulheres, os serviços da Atenção Primária. (BRASIL, MINISTÉRIO DA SAÚDE, 2008)

Fazendo um comparativo entre o adoecimento do homem e da mulher, há certas características a serem observadas: os homens iniciam precocemente o consumo de álcool, tendem a beber mais e a ter mais prejuízos em relação à saúde do que as mulheres. (BRASIL, MINISTÉRIO DA SAÚDE, 2008)

A prevalência de dependentes de álcool também é maior para o sexo masculino: $19,5 \%$ dos homens são dependentes de álcool, enquanto $6,9 \%$ das mulheres apresentam dependência. Segundo esses dados, para cada 
seis pessoas do sexo masculino que fazem uso de álcool, uma fica dependente. Entre as mulheres, essa proporção é 10:1. (CEBRID, 2005 apud BRASIL. MINISTÉRIO DA SAÚDE, 2008, p.13)

Segundo a Política Nacional de Saúde do Homem (BRASIL. MINISTÉRIO DA SAÚDE, 2008), existem seis milhões de pessoas, entre homens e mulheres, em situação de dependência de álcool. Essas informações nos revelam o impacto que o álcool gera à saúde da população, e esses comparativos apontam para a necessidade urgente de ações intersetoriais que gerem e permitam atenção integral a esses usuários vulneráveis a riscos de adoecimento social e de saúde, inclusive para a APS. Isso justifica a importância de não se delimitar à classificações e/ou à categorização do comportamento de risco, mas de manter uma perspectiva de atenção nas duas dimensões humanas, individual e relacional.

Para Vargas, Oliveira e Luís (2010) é na APS e a partir da atuação da ESF e seus métodos de acompanhamento, que se vinculam ações e intervenções na vida dos cidadãos. Portanto, é através desse serviço que os usuários devem obter a assistência e os encaminhamentos para a resolução de suas queixas de saúde, uma vez que o profissional encontra-se como cuidador mais próximo do usuário e de seu cotidiano.

Essa atuação da ESF, que se configura como a porta de entrada da assistência em saúde para o usuário, deve ser capaz de conhecer a dinâmica do território, seus aspectos e hábitos culturais, apresentando maior capacidade e habilidade em estabelecer vínculo e proporcionar as articulações intersetoriais a favor da redução dos riscos envolvidos, sociais e orgânicos, advindos do consumo exagerado do álcool como: problemas fisiológicos, violências, conflitos familiares, desemprego e exclusão social, dentre outros. (BRASIL. MINISTÉRIO DA SAÚDE, 2013)

Tais articulações intersetoriais são entendidas como articulações de saberes e experiências no planejamento, realização e avaliação das ações, com o intuito de alcançar resultados positivos e integrados nessas situações complexas, objetivando promover impacto relevante na vida dos usuários a favor da reversão desses riscos. (LIMA; BRAGA; MARINHO, 2011)

Desta forma, o sistema de saúde deve assegurar capacitação profissional e recursos tecnológicos de cunho intersetorial, através de ações que promovam e previnam o avanço desse uso abusivo ou dependência alcóolica, capazes de detectar as fragilidades e necessidades dos usuários precocemente.

Dentro dessa especificidade, o Ministério da Saúde (BRASIL. MINISTÉRIO DA SAÚDE, 2013) explica a importância da Atenção Primária como porta de entrada prioritária dessa assistência e os demais núcleos que contribuem para a assistência do alcoolista. Percebe-se maior avanço a partir da implantação do Centro de Apoio Psicossocial de Álcool e Drogas (CAPS AD), que tem por base o tratamento do usuário, através de atividades terapêuticas e preventivas focando sua inserção no meio familiar e social. (BRASIL. MINISTÉRIO DA SAÚDE, 2002)

Sobral, cidade situada na região norte do estado do Ceará, tida como referência na APS, tem um CAPS AD como centro de referência, cujo início de suas atividades foi em setembro de 2002, sendo o mais recente dispositivo da Rede de Atenção Integral à Saúde Mental, tendo a APS como ordenadora e coordenadora do cuidado. (GOMES, 2004) Atua prevenindo o uso de substâncias psicoativas com a possibilidade de oferecer tratamento e desintoxicação em leito ambulatorial, aos casos leves e moderados, em 
regime de permanência-dia para os municípios de Sobral e circunvizinhos, de acordo com a pactuação dos gestores; bem como internações para desintoxicação no Hospital Geral Municipal Dr. Estevam, nos casos mais graves. Os pacientes que buscam o suporte do CAPS AD devem ser capazes de compreender a lógica de funcionamento desse órgão, que trabalha na perspectiva de redução de danos, oferecendo ao usuário a autonomia de ir e vir em busca de tratamento sem exigir que o mesmo, obrigatoriamente, abstenha-se do consumo do produto como condição de garantir tratamento ou obter o acompanhamento necessário.

Contudo, durante o trabalho da Residência Multiprofissional em Saúde da Família no território do bairro Dom Expedito ${ }^{1}$, mais especificamente pela categoria de enfermagem, que assume corresponsabilização sanitária sobre uma área adscrita, foi identificada uma grande lacuna em que o usuário abandona a assistência oferecida pelo CAPS AD por não conseguir dar continuidade ao tratamento por diversas razões. Encontramos ainda, usuários que nunca procuraram tratamento para o uso abusivo do álcool porque encontram empecilhos pessoais ou de trajeto para o CAPS AD e ainda, uma parcela de usuários que não utilizam nem mesmo os serviços da ESF. Assim, entendemos que as dificuldades que os levam a não procurar esses atendimentos transpassam as queixas orgânicas, adentrando em uma esfera social e moral que os impede de encarar iniciativas que os levem à busca desse cuidado, o tratamento para o alcoolismo.

\footnotetext{
1 O bairro Dom Expedito compõe parte significativa da margem direita do rio Acaraú. Vale ressaltar que neste território localiza-se uma área crítica, de risco ambiental e social. De acordo com o Instituto Brasileiro de Geografia e Estatística (IBGE), o Dom Expedito possuía, em 2014, população de 6.569 habitantes e 219,073 km², além do bioma da Caatinga.
}

Frente a esta realidade, a posição da ESF é privilegiada, devido à sua proximidade com seus usuários e território, e a possibilidade de contribuir para a compreensão da dinâmica do uso abusivo de álcool e suas repercussões. Dirige-se a colaborar no sentido de esclarecer a necessidade ou a falta de assistência para a promoção, prevenção e reabilitação dos usuários de bebidas alcóolicas, já que esse nível de atenção é responsável pela coordenação do cuidado. Logo, é preciso compreender a atuação desse serviço na tentativa de diminuir o consumo prejudicial para saúde e identificar ações mais práticas e eficazes que promovam maior vínculo entre usuários e a unidade de saúde.

O presente estudo relata as contribuições da ESF e o cuidado com a população usuária de bebida alcoólica. Para a Política Nacional de Atenção Integral à Saúde do Homem (BRASIL. MINISTÉRIO DA SAÚDE, 2008), a ESF deve ornar a atenção primária com estratégias humanizadas, a fim de fortalecer e garantir as articulações das ações e serviços ofertados. A operacionalização desse cuidado remete ao debate das tecnologias leves em saúde, à medida que desenvolve a produção de autonomização, acolhimento, vínculo e gestão, o que o caracteriza também como de alta complexidade. (MERHY, 2002)

A imersão de dois anos no território e o trabalho desenvolvido na ESF durante esse período trouxenos oportunidade de conhecer algumas fragilidades e particularidades de saúde da comunidade. Com um olhar mais atento à relação Unidade de Saúde e usuários de bebidas alcoólicas, nos foi possível relatar a experiência, as percepções e vivências desses usuários que participaram de grupos de autocuidado, visando à promoção da saúde e preservação da vida dos homens. 


\section{Metodologia}

Trata-se de um relato de experiência resultante de uma vivência realizada em dois momentos. O primeiro teve por objetivo estabelecer um diálogo com a comunidade a partir de ações interprofissionais em um Centro de Saúde da Família de Sobral, durante o período noturno, justamente pela impossibilidade de muitos homens participarem das atividades durante o período diurno. No segundo momento, realizamos uma visita em determinada rua da área territorial desse mesmo Centro de Saúde da Família para observar as nuances da rotina do usuário alcoolista.

Nesse processo, o diário de campo foi fundamental para o registro dos eventos. Todas as observações foram registradas no diário. Posteriormente, essas informações foram sistematizadas e problematizadas com base nesses dois momentos. Todavia, no sentido de manutenção dos aspectos éticos da pesquisa, foram utilizados nomes fictícios para os sujeitos presentes nesses cenários, assim como para os bares.

\section{Relato de experiência}

Para uma contribuição mais precisa desse relato, além da vivência dos dois anos de Residência Multiprofissional em Saúde da Família, utilizamos dois momentos de atividades de Educação em Saúde voltados para a saúde do homem:

Momento I - Ocorreu em novembro de 2014, num encontro noturno, no horário das dezoito às vinte horas, na ESF, período que possibilitou a participação da comunidade que trabalha e não pode frequentar as atividades da unidade durante o dia. Nesse encontro multiprofissional, o objetivo foi promover informações e oferecer assistência de promoção e prevenção de agravos à saúde do homem, abordando diversos temas como: alimentação saudável e prevenção da Hipertensão Arterial e da Diabetes; prevenção do uso de álcool e outras drogas; antropometria com avalição corporal; testagem rápida de sorologias para Sífilis e HIV; aferição de pressão arterial e glicemia capilar; avaliação e atendimento odontológico; prevenção das doenças sexualmente transmissíveis com demonstração do uso e distribuição de preservativos masculinos, dentre outras informações e encaminhamentos necessários aos participantes.

Para o Ministério da Saúde (BRASIL. MINISTÉRIO DA SAÚDE, 2008), esses temas, entre outros, são essenciais na abordagem de promoção e prevenção à saúde do homem, visto que ele encontra-se culturalmente mais vulnerável às morbimortalidades, além da menor adesão do mesmo frente à procura de prevenção primária. Constatamos que embora tenha sido uma atividade de efetiva participação da comunidade masculina, alguns usuários que se encontram à margem dos serviços da ESF não compareceram. Assim, para essa demanda masculina foi realizado em fevereiro um momento alternativo de participação.

Momento II - Aconteceu na Rua Espanha, popularmente conhecida pelos profissionais de saúde como "Alcoolândia", onde se localizam os bares de venda de bebidas alcoólicas conhecidos como bar do Babá, do Marcos, do Alison, do Popó e a casa da Juliete, todos localizados na mesma rua. Esses estabelecimentos funcionam durante o dia, exceto a casa da Juliete, que abre somente à noite para venda de bebidas. Para a agente comunitária de saúde, o movimento e o consumo, à noite, é intenso, os frequentadores chegam a amanhecer "caídos" pelas calçadas, acontecimento rotineiro e comum para a 
comunidade e moradores vizinhos. A escuta dos relatos, no bar do Babá, nos revelou as reais queixas de moradores de diversas faixas etárias que fazem uso de bebidas alcóolicas diariamente, sendo possível encontrar pessoas que há mais de 30 anos frequentam o local.

Segundo o Ministério da Saúde (BRASIL. MINISTÉRIO DA SAÚDE, 2008), os homens iniciam uso de bebida alcoólica precocemente e representam $20 \%$ de internações devido a transtornos mentais e comportamentais relacionados ao uso abusivo dessa droga. Muitos dos usuários relatam que iniciaram o uso de bebida alcoólica por volta dos 12 anos, hoje entre os 28 e 65 anos, todos apresentam longos períodos fazendo uso de álcool e passagens pela referência em atendimento de urgência hospitalar, o Hospital Dr. Estevam.

Questionamos se eles lembravam por que iniciaram tão cedo a beber e como resposta esses usuários nos informaram que associam esse hábito a outros familiares ou conhecidos que também faziam uso de bebidas e frequentavam os bares, o que facilitava aos garotos o contato precoce com a ingestão de álcool. Podemos, então, identificar que uma das portas de entrada para o alcoolismo é a família.

O uso do álcool demonstrou, também, ser um fator de risco para o uso de outras drogas e a fase da adolescência é o período de maior vulnerabilidade para o ingresso no uso de substâncias psicoativas. Dentre alguns dos fatores de risco para esse ingresso, destacam-se o uso dessas substâncias pelos pais e amigos e o desenvolvimento de sintomas depressivos. (IBGE, 2009)

Assim, percebemos que a escolha da bebida também tende a ser sempre a mesma que os demais familiares ou companheiros ingerem. A bebida destilada (cachaça) é a principal por ser financeiramente menos onerosa em relação a outras bebidas disponíveis naquele cenário, podendo ser comprada por um valor que varia de cinquenta centavos a dois reais, além de levar de forma mais rápida à embriaguez, fato que ajuda os que passam longos períodos noturnos na pescaria do rio Acaraú ${ }^{2}$, já que numa dose de cachaça aproximadamente $45 \%$ é álcool, considerando uma dose-padrão $(40 \mathrm{ml})$, ou seja, $17 \mathrm{ml}$ de álcool puro (BRASIL. MINISTÉRIO DA JUSTIÇA. SECRETARIA NACIONAL DE POLÍTICAS SOBRE DROGAS, 2011)

Esse segundo momento de atividade educativa teve o propósito de gerar uma aproximação maior com os usuários que não participam e nem frequentaram as atividades realizadas na Unidade de Saúde. Para Vasconcelos (2004), esse momento do território, de educação popular, é esclarecedor e essencial para gerar reflexões para a promoção e prevenção dos agravos, além de despertar para as discussões locais voltadas para o que se propõe, pois permite habitar, conhecer in loco e trocar experiências nos territórios.

Todos os usuários foram receptivos e colaboraram com as discussões, tendo sido capazes de descrever e reconhecer os sinais do corpo quando ingerem volumes exagerados de álcool, além de indicar reconhecer, entre eles, os que precisam de mais cuidado. Citaram ainda, exemplos negativos como a morte recente de uma moradora usuária que vendeu a pouca mobília da casa para o consumo de cachaça por um longo período até ir à óbito.

Descreveram também momentos em que permanecem no uso contínuo de cachaça e apresentam

\footnotetext{
2 O rio Acaraú banha o estado do Ceará, em que percorre por $320 \mathrm{~km}$. Banha diversos municípios, dentre eles, Sobral. Em especial, no contexto em que foi realizada essa vivência, o espaço era mais utilizado para a realização de práticas esportivas e de lazer, pesca, lavagem de roupas, travessia por meio de canoa, além da ingestão de bebidas alcoólicas.
} 
delírios, tendo visões com a presença de monstros e outras figuras negativas emergentes quando o usuário está sob o efeito álcool. Declararam reconhecer o momento de parar, pois admitiram que bebem por longos períodos, ora misturando a bebida à substâncias ilícitas, ora não, e justificaram o entendimento de autocontrole pelo fato de que acreditam não perderem totalmente a consciência e saberem o que estão fazendo nesse período de consumo.

Para Ramos e Woitowitz (2004), esses efeitos nocivos reverberam em problemas de saúde pública e mental de magnitude complexa e são reflexos de um consumo de álcool de $90 \%$ da população adulta, dos quais $10 \%$ irão apresentar o uso nocivo e outros $10 \%$ irão tornar-se dependentes.

Esses efeitos nocivos ocasionados pelo uso excessivo do álcool foram identificados durante o decorrer da conversa, pois houve relatos de usuários que há três dias ingeriam apenas cachaça e água porque não conseguiam consumir nenhum outro alimento. Também havia usuário que não estava sob o efeito de álcool, mas estava debilitado apresentando diarreia sanguinolenta há mais de uma semana e outros sinais visíveis de desidratação, além de apresentar descamação na pele dos braços e costas. Todos apresentavam queixas gástricas recorrentes.

Além das causas externas e dos tumores, há muitas outras causas de mortalidade que podem ser assinaladas. Dentre as doenças do aparelho digestivo, por exemplo, podemos destacar as doenças do fígado que, em 2005, foram responsáveis por $70 \%$ das causas de morte de homens de 25-59 anos. Destas, 46\% devem-se à doença alcoólica, $6 \%$ à fibrose e cirrose, e $18 \%$ a outras doenças do fígado. (BRASIL. MINISTÉRIO DA SAÚDE, 2008)

Quando perguntamos se algum deles já havia procurado assistência de saúde na ESF por alguma dessas queixas, a resposta foi que conheciam a ESF para fins de outros atendimentos e faziam pouca relação das queixas clínicas e/ou traumáticas com o uso de bebida alcoólica. Outros declararam que nunca foram à unidade de saúde por qualquer motivo, além de acreditarem que para o tratamento ou abordagem em relação ao consumo de bebida etílica deviam dirigir-se ao CAPS AD. Um deles relatou já ter realizado a tentativa de iniciar um tratamento ambulatorial no CAPS AD, porém, não teve motivação para dar continuidade e acabou abandonando o tratamento por entender que não precisava do seguimento da assistência. Um usuário de 28 anos, que consome cachaça há 16 anos, relatou que já esteve internado no Hospital Municipal Dr. Estevam e acredita que um dos motivos do insucesso do tratamento é justamente a internação hospitalar, já que o período de internação é compartilhado com demais internos, que apresentam outros transtornos mentais, o que na opinião dele torna-se intranquilo, além de ter reconhecido que a força do vício é maior.

O Ministério da Saúde (BRASIL. MINISTÉRIO DA SAÚDE, 2008) relaciona a baixa adesão ao tratamento aos esquemas terapêuticos, bem como pelas inevitáveis barreiras socioculturais e institucionais frente às necessidades de mudanças de hábitos de vida. Além do que, esse estereótipo de gênero apresenta maior dificuldade de aceitar a possibilidade de doença, apresentando o medo de ir ao médico e descobrir que está doente face às atribuições que lhe competem com o sustento da família.

Dentre tantas percepções, ressaltamos o grau de companheirismo e afinidade entre eles, a convivência no bar do Babá, assim como nos outros bares, é sempre pelos mesmos consumidores, fato que torna esse espaço um ponto de referência para a bebida e para o encontro de vizinhos e negócios. Nesse contexto, todos os usuários possuem apelidos. 
No momento em que foi realizada a abordagem na comunidade, tomamos cuidado para que não houvesse alteração do cenário encontrado: enquanto uns consertavam o náilon de uma rede de pesca, outros realizavam a manutenção de material de mergulho, outros lixavam peças de aço de uma bicicleta, enquanto outros bebiam e conversavam. E assim, segundo o relato do Sr. Babá ocorre praticamente todos os dias.

Diante dessas vivências, percebemos que embora haja uma lacuna na oferta de assistência por parte da atenção básica a esse público, a atividade desenvolvida foi oportuna para informar sobre os serviços que a Atenção Primária pode oferecer a esses usuários assim como, alertar para o consumo exagerado de álcool, explicando que todo e qualquer sintoma decorrente desse fato pode ser aliviado e/ou medicado por ocasião do atendimento na unidade de saúde, no território (quando não houver necessidade de referenciar o paciente), já que muitas queixas gástricas são ignoradas e/ou aliviadas com mais uma dose de bebida, segundo relato de um dos usuários.

Essa compreensão pôde ser comprovada quando um dos usuários que se encontrava gravemente debilitado reconheceu a necessidade de ser referenciado para internação no Hospital Dr. Estevam. Assim, entendemos que os serviços de saúde devem ampliar seus elos de atuação intersetoriais frente às questões culturalmente enraizadas, relativas ao alcoolismo, o que implica provocar discussões de estratégias a serem elaboradas que contemplem soluções oportunas ao contexto apresentado.

\section{Considerações finais}

O desenvolvimento desse trabalho permitiu identificar que a APS tem possibilidades de realizar atividades que promovam e previnam agravos voltados à saúde masculina, a partir das observações dos hábitos dos usuários. Percebemos que algumas situações do adoecer fogem dos olhos e da atenção dos profissionais de saúde.

Os usuários de bebida alcoólica do bairro Dom Expedito relataram não fazer uso dos serviços da ESF em situações de embriaguez ou complicações em decorrência do álcool por desconhecerem o papel desse dispositivo. Nos foi possível, então, a partir dos momentos vivenciados, repassar informações acerca do papel da ESF aos usuários para que os mesmos obtivessem uma maior compreensão dos serviços dessa Estratégia na prevenção e tratamento de situações agravantes ou que caracterizam desvio ao padrão normal da saúde, fortalecendo o senso de autonomia desses indivíduos para a busca de tratamento e esclarecimento de dúvidas na Unidade. Além da busca autônoma do usuário, é importante que o profissional permanentemente busque estratégias que o aproximem da comunidade e que the permitam adentrar nos territórios, estabelecendo vínculos de forma a manter um olhar vigilante na identificação de demandas que estejam em sofrimento orgânico ou social decorrente de fatores que condicionam e determinam a doença.

É notório que a Política Nacional de Atenção Integral à Saúde do Homem, que entre outras ações inclui o alcoolista, não trará resultados positivos para a Atenção Primária se não tiver a comunidade masculina ciente da sua existência e de sua finalidade, através das ações e divulgações da ESF, CAPS AD e da rede de saúde mental do município fixando, assim, seu papel para a comunidade e sociedade. Além da 
divulgação com foco no esclarecimento, resultados mais efetivos no tratamento do alcoolista podem ser conseguidos com estratégias de internação voluntária para o tratamento de usuários de bebida alcoólica e outras drogas, as quais, se adotadas, podem surtir efeito positivo na recuperação e reabilitação do usuário.

Muito embora consideremos que há muito a ser realizado dentro do território no tocante à saúde do homem, reiteramos a importância da atuação da Residência Multiprofissional em Saúde da Família quanto às possibilidades de promover ações que contribuam e sejam impulsionadoras para o trabalho dos serviços de saúde, através de colaborações construtivas e viáveis na educação e informação dos usuários.

\section{Referências}

BRASIL, Ministério da Justiça. Secretaria Nacional de Políticas sobre Drogas. Drogas: cartilha álcool e jovens. 2ed. Brasília, 2011.

BRASIL, Ministério da Justiça. Secretaria Nacional Antidrogas. I Levantamento Nacional sobre os Padrões de Consumo de Álcool na População Brasileira. Brasília, 2007.

BRASIL, Ministério da Saúde. Portaria GM n. 336, de 19 de fevereiro de 2002. Estabelece que os Centros de Atenção Psicossocial possam constituir-se nas seguintes modalidades de serviço: CAPS I, CAPS II e CAPS III. Ministério da Saúde, 2002.

BRASIL. Ministério da Saúde. Política Nacional de Atenção Integral a Saúde do Homem. Brasília: Ministério da Saúde, 2008.
BRASIL. Ministério da Saúde. Departamento de Ações Programáticas e Estratégicas. Cadernos de Atenção Básica, n.34. Brasília: Ministério da Saúde, 2013.

GOMES, B.V. Centro de Atenção Psicossocial - Álcool e outras Drogas: descrevendo o funcionamento do serviço em Sobral-CE. Monografia apresentada no curso de enfermagem da Universidade Estadual Vale do AcaraúUVA. Sobral, 2004.

INSTITUTO BRASILEIRO DE GEOGRAFIA E ESTATISTICA (IBGE). Pesquisa Nacional de Saúde do Escolar, 2009. Disponível: www.ibge.gov.br/home/estatistica/populacao/ pense.pdf Acesso em: 15 set 2013.

LIMA, H.P.; BRAGA, V.A.B.; MARINHO, A.M. Rede De Apoio Social Ao Alcoolista: Mapeamento Baseado Nas Ações Intersetoriais De Alcoólicos Anônimos. Rev. Rene, Fortaleza, v.12, n.1, p.33/44, jan/mar, 2011.

MACHADO, M.F.A. S et al. Integralidade, formação de saúde, educação em saúde e as propostas do SUS - uma revisão conceitual. Ciência \& Saúde Coletiva, v.12, n.2, p.335-342, 2007.

MERHY, E.E. Saúde: cartografia do trabalho vivo em ato. São Paulo: Hucitec, 2002.

RAMOS, S.P.; WOITOWITZ, A.B. Da cervejinha com os amigos à dependência de álcool: uma síntese do que sabemos sobre esse percurso. Revista Brasileira de Psiquiatria, São Paulo, v.26, p.18-22, 2004.

VARGAS, D.; OLIVEIRA, M.A.F.; LUÍS, M.A.V. Atendimento ao alcoolista em serviços de atenção primária à saúde: percepções de condutas do enfermeiro, Acta Paul Enfermagem, v.23, n.1, p.73/9, 2010. 
VASCONCELOS, E.M. Educação Popular: de uma prática alternativa a uma estratégia de gestão participativa das políticas de saúde. Physis, Rio de Janeiro, v.14, n.1, p.67-83, 2004.

\section{ACOLHIMENTO INTERDISCIPLINAR EM SAÚDE MENTAL NA ATENÇÃO PRIMÁRIA À SAÚDE}

Maria das Graças Sousa Maria Lidiany Tributino de Sousa

\section{Entendendo o tema}

Acolher significa, entre outras coisas, dar ouvidos a, tomar em consideração. $O$ acolhimento pode significar a facilitação do acesso da população aos serviços de saúde, o oferecimento de assistência adequada, bem como receber, escutar e cuidar de forma humanizada das pessoas e de suas necessidades. (FRANCO; BUENO; MERHY, 1999)

O acolhimento em saúde torna-se o momento inicial do contato do usuário com o sistema de saúde e está relacionado à escuta das queixas, da situação de adoecimento e de toda história do processo de saúde/ doença do usuário, possibilitando que este sinta-se confortado nas situações de sofrimento, a partir de um atendimento atencioso e receptivo do seu problema. 
Acolhimento é uma proposta voltada para a melhoria das relações dos serviços de saúde com os usuários. Neste caso, concretiza-se no encontro do usuário que procura o serviço, espontaneamente, com os profissionais de saúde, quando há uma escuta, um processamento de sua demanda e a busca de resolução, se possível. (TESSER; NETO; CAMPOS, 2010, p.3620)

De acordo com estimativas, a Estratégia Saúde da Família (ESF) atende 103 milhões de pessoas, sendo que 5 milhões, em média, apresentam algum transtorno mental severo ou percebe-se que grande parte dos usuários com adoecimento psíquico são demandas da Atenção Primária à Saúde. (BRASIL. MINISTÉRIO DA SAÚDE, 2013)

A atenção à Saúde Mental está inserida na Atenção Primária, pois o vínculo com as famílias e com a comunidade facilita a ação de cuidado com as pessoas com sofrimento mental. É no território que se encontram os determinantes de adoecimento e as potencialidades de cuidado.

Segundo Livalter (2012), a ESF com base nos princípios do Sistema Único de Saúde (SUS), tem como prioridade acolher e garantir o acesso do usuário ao serviço de saúde. No caso de pacientes com transtorno mental, que apresentam uma bagagem de história de violação de direitos, a ESF deve garantir a dignidade do cuidado e um trabalho a partir dos determinantes do processo saúdeadoecimento.

No Centro de Saúde da Família (CSF) Alto da Brasília, do município de Sobral, Ceará, as ações de cuidado em Saúde Mental estão sendo priorizadas no acolhimento ao usuário que apresenta algum tipo de transtorno mental. Esse processo iniciou-se em março de 2009, quando uma equipe de profissionais de saúde demonstrou sua insatisfação com o atendimento a pacientes com sofrimento psíquico. A atenção à saúde desses pacientes estava focada na prescrição de medicamentos de controle especial e/ ou encaminhamentos ao Centro de Atenção Psicossocial (CAPS), ou ainda, para as Preceptorias de Psiquiatria ${ }^{1}$.

Motivados pela capacidade transformadora e considerando a escuta das queixas apresentadas pelas famílias residentes no território, profissionais da Residência Multiprofissional em Saúde da Família (RMSF), Agentes Comunitárias de Saúde (ACS) e profissionais do Núcleo de Atenção à Saúde da Família (NASF), propuseram uma nova organização para as ações de cuidado em Saúde Mental. Inicialmente, elaboraram uma proposta de trabalho denominada: Ambulatório em Saúde Mental (ASM). O ASM era orientado por uma ação interdisciplinar e estava à disposição da comunidade de forma sistemática e permanente, sendo um espaço de escuta e troca de saberes.

Essa iniciativa foi incorporada ao cronograma de ação dos profissionais da saúde. O ASM passou a atender semanalmente pacientes agendados. Cada semana uma equipe composta por enfermeiro, ACS, NASF e RMSF ficava responsável por esse atendimento. O ASM configurou-se, então, como um dispositivo de acolhimento, no contexto da ESF, para as pessoas com transtornos mentais.

Posteriormente, o ASM passou por avaliações internas e consequentes mudanças. Acreditando que a palavra Ambulatório gerava uma associação com o atendimento individual e com a terapêutica medicamentosa, a equipe de profissionais renomeou esse dispositivo para Acolhimento Interdisciplinar em Saúde Mental (AISM); entendendo-o como uma tecnologia de cuidado à saúde. Tecnologia aqui

\footnotetext{
1 Conforme relato de Tófoli e Fortes (2007), as Preceptorias de Psiquiatria, no município de Sobral, também denominadas Preceptorias de Saúde Mental, referem-se a momentos em que um preceptor (neste caso, o médico psiquiatra) desloca-se do serviço especializado para o Centro de Saúde da Família para desenvolver ações de apoio às equipes de referência, de forma técnica e pedagógica.
} 
é compreendida em seu sentido largo, não reduzido a equipamento, mas como ação transformadora.

$\mathrm{O}$ isolamento social, a exclusão e a violência contra as pessoas com doenças psíquicas são situações ainda muito presentes no cotidiano dos usuários, além do que persistem grandes lacunas nos modelos de atenção e gestão dos serviços, no que diz respeito ao acolhimento. Tecnologias de cuidado como o AISM podem produzir respostas satisfatórias a essas lacunas. Neste sentido, objetiva-se analisar o AISM, sob a ótica dos profissionais de saúde que nele atuam ou atuaram, incluindo os usuários. A análise visa a identificação de desafios e propostas para qualificação do Acolhimento Interdisciplinar em Saúde Mental.

\section{Percurso metodológico}

Trata-se de um estudo qualitativo, analítico crítico. Segundo Godoy (1995), a pesquisa qualitativa não envolve dados estatísticos, descreve o que o analisador observa, compreendendo os diversos fenômenos de acordo com sua participação direta no processo.

O estudo foi realizado num Centro de Saúde da Família, localizado numa cidade do semiárido cearense, no período de agosto de 2013 a fevereiro de 2014. Entrevista e grupo focal foram os instrumentos utilizados para apreender os dados.

A princípio, realizou-se entrevista semidirigida com dois usuários que participaram de forma recursiva do AISM e que apresentaram disponibilidade e interesse. As entrevistas foram realizadas no próprio CSF.

Para os profissionais, a opção foi pelo grupo focal. Foram realizados dois grupos focais. Para o primeiro foram convidadas quatro pessoas que participaram da construção do AISM: enfermeira residente em Saúde da Família, tutor de território, Agente Comunitária de Saúde e o Matriciador em Saúde Mental (Médico Especialista). O número restrito de participantes deveu-se ao fato de não ter sido possível localizar demais profissionais que fizeram parte da construção dessa tecnologia de cuidado. Para o segundo grupo focal foram convidados sete profissionais que atualmente participam do AISM, sendo eles: três enfermeiros, três profissionais do NASF e um profissional da RMSF.

A seleção dos sujeitos foi intencional, no sentido da escolha de atores considerados estratégicos tanto no início do AISM, quanto dentre os que atuam na operacionalização desse serviço atualmente.

Esses encontros grupais foram previamente marcados de acordo com a disponibilidade dos membros de cada grupo. O primeiro grupo focal foi conduzido pela pesquisadora que apresentava pouco vínculo com os participantes e o segundo grupo foi conduzido por uma colaboradora, para que os membros não se sentissem constrangidos e nem receosos em declarar suas opiniões. Os grupos focais também aconteceram no CSF em dias alternados.

Para dinamizar a técnica do grupo focal recorreu-se ao Jogo de Trilhas. Para o jogo utilizou-se um dado e um tabuleiro no chão da sala com uma numeração de 01 a 20. Os jogadores foram identificados por uma numeração e a cada lance do dado, o jogador responsável percorria o respectivo número de casas do tabuleiro, respondendo à pergunta correspondente ao número da casa na qual parou. As perguntas foram de acordo com o objeto de investigação, havendo também algumas atividades lúdicas. 
Buscando realizar uma reflexão sobre os conteúdos manifestos a partir dos resultados, utilizou-se nesta pesquisa a análise temática como recurso metodológico de análise de dados.

Fazer uma análise temática consiste em descobrir os núcleos de sentido que compõem uma comunicação, cuja presença ou frequência signifiquem alguma coisa para o objetivo analítico visado. Ou seja, tradicionalmente, a análise temática encaminha-se para a contagem de frequência das unidades de significação como definitórias do caráter do discurso. (MINAYO, 2004, p.209)

Assim, dosconteúdos das falas sobressaíram os núcleos de sentido, os quais foram organizados, inicialmente, a partir das categorias: potencialidades, desafios e percepções dos participantes acerca dessa tecnologia de cuidado.

A pesquisa seguiu as diretrizes e normas regulamentadoras de pesquisas envolvendo seres humanos. Para preservação da identidade, os sujeitos foram identificados sequencialmente como jogadores, e de acordo com a técnica de coleta de dados na qual participaram. Ex: Jogador 1 do Grupo Focal 1 (JG1 do GF1). Todos os sujeitos anuíram participar do estudo.

\section{Resultados e discussões}

Compreendendo que o acolhimento torna-se a porta de entrada da atenção primária, sendo esse o espaço de escuta e cuidado da pessoa que chega com algum tipo de sofrimento, os dados foram organizados seguindo os núcleos de sentido: acolhimento como espaço de troca, de escuta, criação de vínculos, cuidado integral, desafios e possibilidades.
Os discursos dos sujeitos retomam o processo de construção do AISM, já narrados na introdução deste capítulo.

[...] quando veio a Residência... que chegou foi organizando e começou o ambulatório, a gente começou a se reunir e realmente começar a procurar "catar" nas nossas áreas as pessoas que tomavam esses medicamentos controlados... a gente foi saber o que era medicamento controlado... dos pacientes que tomavam. (JG1, GF1)

A participação das ACS foi essencial para essa organização do serviço. Elas traziam os casos da comunidade, discutiam e procuravam solução para as dificuldades, compartilhando o conhecimento que têm das necessidades dos usuários e do contexto das famílias pelas quais são responsáveis.

A partir da busca ativa dos casos e direcionamento das pessoas para o ASM, também iniciou um processo de educação permanente com os profissionais e trabalhadores de saúde nessa direção. Houve encontros para compartilhamento do teor do instrumento de avaliação em saúde mental que foi desenvolvido; elaboração de genogramas e ecomapas das famílias, identificação das medicações de controle especial e dos transtornos mais comuns no território.

O ASM foi organizando-se, compreendendo encontros semanais pelas manhãs, realizados com a participação das enfermeiras e de profissionais das equipes multiprofissionais (RMSF e NASF).

[...] eu tinha na minha agenda, quando eu cheguei, um turno de atendimento pra saúde mental no território na minha 
área adscrita e aí esse turno eu sempre fazia com as residentes que compunham a minha equipe. (JG3, GF1).

Devido a essa organização dos atendimentos em saúde mental, o CSF Alto da Brasília tornou-se uma referência para outros CSF nesse município.

Permite que a equipe local... como a equipe do CSF esteja ciente sabendo o que está acontecendo e permite fazer uma espécie de triagem daqueles casos mais necessitados para o matriciamento.... faz diferença $o$ acolhimento que acontece aqui em relação a outros territórios onde não tem esse tipo de atuação da equipe. (JG1, GF1).

Uma vez apresentados os registros pertinentes ao processo de idealização e de criação do AISM, passa-se a discorrer sobre suas potencialidades.

\section{Potencialidades do AISM}

Diante das falas dos sujeitos, percebeu-se que o AISM tem se configurado como um espaço de troca que favorece o enriquecimento nas experiências de cuidado, a aprendizagem do profissional e do usuário, bem como a compreensão por parte dos envolvidos de que o cuidado à pessoa com transtorno mental não pode ser restrito à medicamentalização.

[...] eu acredito que é muito isso [...] do aspecto da aprendizagem na perspectiva de um cuidado integral que a gente pode fazer pelo usuário... da aprendizagem da gente. (JG2, GF1)
O acolhimento interdisciplinar propicia um espaço de troca de saberes entre os profissionais e destes com os usuários, respeitando os conhecimentos particulares e apresentando um compromisso ético nas relações que deverão existir.

Durante essas trocas, o profissional consegue interagir com os conhecimentos técnicos e específicos, gerando um maior aprendizado dos problemas que surgem no território e apresentando propostas de cuidado mais ampliadas.

[...] através do acolhimento a gente passa a reconhecer alguns problemas que às vezes num é nem da ação do enfermeiro, é um problema que pode ser avaliado por um psicólogo, um psiquiatra (JG8, GF2)

Para Salvador et al. (2011), a busca pela integralidade do cuidado em relação à prática de atendimento multiprofissional dá-se através da organização do trabalho, levando em conta os diversos saberes e práticas, sendo importante uma interação entre os conhecimentos na busca por uma intervenção ampliada, a qual, isoladamente, nenhum profissional conseguiria realizar.

Entende-se que nessa relação entre os profissionais e na deles com os usuários, a escuta emerge como um saber necessário e potencializador do cuidado. Os nacos de discursos apresentados, a seguir, sinalizam para a compreensão do AISM enquanto espaço de escuta.

Entende-se que o espaço de fala do usuário e a confiança no profissional da atenção primária são importantes para que o plano terapêutico construído com o usuário seja efetivo.

De acordo com Malta (2011) apud Fertig, Braga e Witt (2013, p.09) 
O ato de escuta é um momento de construção, em que o trabalhador utiliza seu saber para a construção de respostas às necessidades dos usuários, e pressupõe o envolvimento de toda a equipe que, por sua vez, deve assumir postura capaz de acolher, de escutar e de dar resposta mais adequada a cada usuário, responsabilizando-se e criando vínculos.

Os espaços de escuta proporcionam ao usuário momentos de desabafo, onde ele consegue externar o que sente, bem como sua problemática, como ressalta um usuário:

Com o acolhimento, a gente conversando, tendo conversa com as pessoas a gente vai até esquecendo, num quer mais fazer aquilo que a gente fez, é o que eu penso agora é de não fazer mais. (US2, ENT)

Para Medeiros et al. (2010), a escuta, a valorização da problemática do paciente, a atenção dada a ele no momento do acolhimento e a identificação das necessidades, tanto individuais como coletivas, também são formas de acolhimento.

[...] de uma maneira geral tanto aqui como nos outros PSFs o usuário geralmente ele é uma pessoa que tá no momento de sofrimento que tá querendo ser ouvido... querendo uma solução ou uma ajuda[...] ele deve se sentir acolhido em diversos momentos (JG1, GF1)

Então o acolhimento tem esse papel de está ouvindo [...] de não ser aquele atendimento [...] é mais uma conversa [...] é mais uma terapia [...] no sentido de tá ouvindo, de tá permitindo essa escuta do paciente (JG5, GF2)
O AISM mostra-se importante na construção e manutenção dos vínculos e dos planos de cuidados, sendo necessário considerar que essa construção se dá a partir do conhecimento do profissional acerca do indivíduo, sua família e território.

As pessoas que estão ali na sala são pessoas confiantes, que com elas que eles têm que contar. Isso pra gente como ACS, como a equipe de saúde é bem gratificante, a gente saber que o próprio paciente se sente bem lá no meio da equipe (JG4, GF1)

Medeiros et al. (2010) referem-se ao acolhimento como um espaço de criação de vínculo e compromisso entre usuário e profissionais, cujas relações favorecem um atendimento humanizado. Ainda, corroborando com a compreensão do acolhimento como espaço construtor de vínculo, Matumoto afirma que:

O acolhimento é uma forma de intervenção que propõe apoio contínuo à pessoa em todo o seu processo de atendimento na saúde e não somente no que diz respeito ao acesso do usuário ao serviço. Abrange o encontro do profissional com esse usuário, num processo de negociação das necessidades deste, promovendo acesso, buscando a produção do vínculo. (MATUMOTO, 1998 apud BORGES; CARDOSO, 2005, p.30)

Diante dos relatos, observa-se que esse é um espaço de troca, escuta e de vínculo, no qual o usuário sente-se confortado nas ações terapêuticas que são pactuadas. De acordo com Machado e Mocinho (2003 apud Morais; Tanaka, 2010), estabelecer acesso e vínculo entre equipe e usuário, no meio onde eles estão inseridos, proporciona 
uma continuidade da atenção às ações de saúde da família, permitindo aos profissionais uma maior vivência no trabalho com pessoas com transtorno mental.

O exposto tende a indicar a configuração dessa tecnologia de cuidado orientada para um cuidado integral, o que representa outra potencialidade do AISM. As ações de cuidado integral destinadas ao usuário com transtorno mental tornam-se o ponto de partida para a melhoria da situação de sofrimento no qual ele está inserido.

0 acolhimento interdisciplinar tem em suas potencialidades, a possibilidade de os profissionais dialogarem e articularem estratégias de cuidado que não necessariamente necessitem de uma terapia medicamentosa, mas que devem ser pactuadas e construídas em espaços de interação.

Consegui ser interdisciplinar [...] é o plano de cuidados que a gente consegue executar....a gente vê o impacto que isso tem[...] isso é outro grande benefício. (JG3, GF1)

Para que hajam as intervenções em saúde mental, os planos terapêuticos devem ser construídos juntos: pacientes e equipe interdisciplinar, utilizando esses espaços de escuta que são bastante importantes na construção do vínculo e das estratégias de cuidado desse indivíduo; conforme já referido e realçado neste depoimento:

Tem um envolvimento de cada profissional... os agentes de saúde principalmente ... e do resto da equipe... da equipe mínima... da equipe multi e se não fosse o envolvimento de cada um e do usuário principalmente... eu acho que não seria tão proveitoso. (JG6, GF2)
Cabral et al. (2001 apud Delfini et al., 2009, p.1485) ressaltam que essas novas iniciativas "devem possibilitar ações integradas, formando uma atuação mais completa, na qual cada equipe possa ora ser responsável direto pelo cuidado ou ação produzida, ora corresponsável, na tentativa de construir diversos dispositivos capazes de produzir saúde."

Sabe-se que, muitas vezes, os usuários de saúde mental procuram o centro de saúde em busca de tratamento medicamentoso que diminua sua sintomatologia, seus sofrimentos e dores. Segundo Tesser, Neto e Campos (2010), essa terapêutica usada de forma exclusiva, não leva em conta os modos de vida e alguns fatores sociais que são importantes no processo saúde-doença.

Ressalta-se aqui, o atendimento interdisciplinar, o qual demonstra outros modos de cuidado, não somente realizados com a presença do médico ou de uma terapêutica medicamentosa, mas com intervenções territoriais e práticas integrativas orientadas nas vulnerabilidades e potencialidades de cada usuário.

[...] é poderpensaroutras possibilidades que não as possibilidades de medicação e o processo da psicoterapia [...] não que isso não seja importante, mas que a gente possa pensar essa diversidade de cuidado e poder compartilhar esse cuidado para que o Posto todo [...] a equipe toda possa compreender a forma como se organizar a forma como acolher. (JG2, GF1)

No momento do acolhimento, a presença do profissional ACS faz-se bastante necessária para que haja esse elo de informações acerca das particularidades do 
usuário, bem como o envolvimento de todos os profissionais no processo de cuidado.

Existe essa sensibilização que é algo fantástico que o serviço, a organização do acolhimento ele concede e aí que vai desde a gerência até o vigia eu acho que ele consegue tomar todo mundo. (JG3, GF1)

Com o intuito de promover a saúde, os espaços de acolhimento na atenção primária devem oferecer um acompanhamento interdisciplinar, como também, terapias alternativas, que não as medicamentosas, sempre observando a situação na qual o usuário encontra-se durante esse atendimento, levando em conta suas questões culturais, crenças, conhecimento popular, dentre outros.

Essas outras formas de cuidado estão disponíveis no CSF Alto da Brasília. Esta unidade possui, além de equipes multiprofissionais (RMSF e NASF), duas massoterapeutas atendendo em dias alternados, bem como diversos grupos sociais e de saúde (grupo de mulheres, grupos de convivência, grupos religiosos, grupos de caminhada, dentre outros):

A gente passa a conhecer o paciente de forma holística [...] a gente passa a ter o paciente como parceiro e eu vejo o acolhimento hoje [...] como um tratamento alternativo [...] então assim, a gente oferece a massoterapia [...] a gente dá um leque de opções [...] levando aquele paciente a ter o autocuidado. (JG8, GF2)

O cuidado que se precisa ter é para que as práticas integrativas não se tornem uma espécie de medicamento, funcionando como uma obrigação, que ao serem prescritas, devem ser cumpridas, como remédio para todos os males.
[...] eu devo... vir pra massoterapia... vir pro grupo de convivência... é o que eu tou fazendo. (US2, ENT)

[...] acho bom... maravilhoso [...] gosto de ouvir [...] mudou sim.. que eu tou tomando meus remedinhos direito... vocês botaram tudo na minha cabeça direito... tome seu remedinho direito.... não esquece o remédio.... às vezes não esqueço não. (US1, ENT)

Para Sousa (2012), há uma consideração de que a terapêutica não se resume aos medicamentos e que é necessária uma ampliação do olhar do profissional para outras formas de cuidado na atenção primária.

A Estratégia Saúde da Família tem como proposta atender pessoas e famílias, através de uma abordagem multiprofissional, no sentido de facilitar a integralidade do cuidado aos usuários do SUS, mantendo viva a proposta da Reforma Psiquiátrica; garantindo uma atenção acolhedora e um cuidado às pessoas com sofrimento psíquico; e gerando vínculos entre os profissionais, a comunidade e o território.

Relacionados os núcleos de sentido: espaço de trocas, de escuta, construção/manutenção de vínculos e cuidado integral como potencialidades do AISM, registram-se os desafios presentes na incorporação dessa tecnologia de cuidado no cotidiano do serviço e, consequentemente, das pessoas.

\section{Desafios do AISM}

A formação profissional descompassada relativa às necessidades dos serviços para atender adequadamente as pessoas com transtornos mentais, o desconforto manifesto 
por algumas pessoas diante do número de profissionais presentes no AISM e a densa agenda dos profissionais, emergiram como situações que precisam ser superadas.

As ações de inclusão da pessoa com transtorno mental, na Atenção Primária, tornam-se essenciais para sua reabilitação psicossocial, porém, ainda configuramse como desafio diante da diversidade de programas da ESF. Podemos observar que, do mesmo modo, existem profissionais receosos com as ações de cuidado e a forma de atendimento a esses usuários, além do que as demandas de território muitas vezes não ajudam no sentido de que haja um atendimento/acolhimento de qualidade.

A minha formação acadêmica... eu acredito como a de muitas outras áreas ela não era voltada para saúde mental e eu tive uma experiência muito frustante com a saúde mental na faculdade e eu disse assim... eu nunca na minha vida vou trabalhar com pessoas que tenham algum tipo de sofrimento psíquico. (JG3, GF1)

Segundo Salvador et al. (2011), os profissionais de saúde não se apresentam preparados em sua formação para atender a demanda necessária existente no país (referindose a pessoas com transtornos mentais).

[...] não tinha uma formação legal pra aquilo, não sabia lidar e tinha preconceitos mesmo com a galera que tem problemas... que sofre...todos nós sofremos na realidade... foi meu primeiro aprendizado profissional pessoal... foi de derrubar mesmo essa barreira que eu construí por uma experiência individual frustante e que eu acabei condenando o resto de uma vida por determinado aspecto... abriu mesmo, aflorou o interesse e o desejo de me aprofundar... me proporcionou... me aproximar da saúde mental compreender um pouco mais de saber lidar com esses pacientes assim com esses usuários, essas pessoas acima de tudo. (JG3, GF1)

Escutando as falas, nota-se que a formação profissional tem criado obstáculos à realização das ações em saúde mental, fazendo com que profissionais não se sintam capazes de fazer parte dessa prática, mas também apontam para a potencialidade do acolhimento interdisciplinar como lugar de aprendizagem e formação.

Outro desafio no AISM é o número de profissionais participantes. Embora alguns colaboradores desta pesquisa defendam que a participação dos profissionais, durante o acolhimento interdisciplinar, gere ao paciente desconforto ao manifestar suas angústias e seu sofrimento psíquico.

[...] os usuários ficam constrangidos pelo que eu percebo com a quantidade de pessoas... de profissionais dentro da sala. (JG9, GF2)

Embora as pessoas manifestem desconforto diante da ação multiprofissional, nota-se que os encaminhamentos gerados e a avaliação coletiva realizada durante esses espaços são necessários para um plano de cuidado eficaz e de fácil acesso, gerando melhorias no atendimento e dando um suporte emocional ao usuário em situação de adoecimento.

Eles ficam assustados quando chegam que vêem aquelas pessoas que eles não tem um contato rotineiro como eles têm com a enfermeira, com o ACS, mas que ao longo da conversa eles se deixam envolver com as perguntas e com a exposição das nossas ações de cada peculiaridade, de cada caso 
e de cada profissional, que a gente tá ali pra atendê-lo e pra escutar. (JG7, GF2)

Outros profissionais acreditam que esse momento, por mais que transpareça uma insatisfação do usuário, torna-se mediador de resolutividade para a problemática de indivíduos que necessitam de escuta, de apoio, de uma palavra de conforto, e que não são vistos somente por essa ótica.

Outros desafios são apresentados, como a agenda dos profissionais da equipe mínima (enfermeiros) para realizar o acolhimento, deixando mais para a equipe multiprofissional (NASF e RMSF) o cuidado com esse momento, no qual há uma participação ativa das ACS.

Entende-se que o AISM, ao apresentar suas potencialidades e desafios, sinaliza possibilidades para um cuidado cada vez mais qualificado.

\section{AISM: Espaço de possibilidades}

Os discursos dos sujeitos sinalizam o AISM como um espaço de cuidado em saúde mental.

[...] é muito importante [...] eu vivia em casa... triste....chorando [...]então, a gente conversando com as pessoas... elas ajudam a gente a caminhar... até se alegrar [...] eu desenvolvi mais... não podia falar... não podia está no meio de gente. (US2, ENT)

[...] o acolhimento pra mim sempre foi uma estratégia muito importante em cuidado em saúde mental [...] ter este momento do acolhimento com a equipe multiprofissional era o espaço que eu preferia estar. (JG2, GF1)
Os profissionais que já atuaram nesse espaço de AISM trazem nas suas falas potencialidades que este serviço vem apresentando, sem desconsiderar, entretanto, a existência de desafios para sua concretude, a exemplo do risco desta tecnologia de cuidado ficar dependente dos profissionais da equipe multiprofissional (NASF e RMSF). Vejamos nas falas a seguir de um profissional do GF1 que fala sobre sua percepção positiva e de outro profissional do GF2 que manifesta sua percepção enquanto profissional do NASF.

[...] mas eu acho que os profissionais que participam deste momento estão muito sensíveis, estão ali trocando mesmo... é um momento muito proveitoso, apesar de saber que existem alguns profissionais que se incomodam ainda de está nesse espaço... ainda ficam apreensivos com tudo que acontece... pela questão do preconceito... o usuário... ele se sente muito à vontade mesmo sendo muitos profissionais... mas em todas as vezes que a gente participa a gente pergunta... questiona se pode ficar todos... se não pode... e ele participa. (JG3, GF1)

[...] nas quintas-feiras... nas agendas [...] posso falar pela questão de NASF nós não temos nada... só é simplesmente o acolhimento de saúde mental. (JG7, GF2)

\section{Conclusão}

Percebe-se o AISM como favorecedor de escuta qualificada, vínculo, troca de saberes, novas propostas terapêuticas e cuidado integral, princípios norteadores da Atenção Primária. Faz-se importante, portanto, no campo 
da Atenção Primária, especificamente, na organização da ESF uma lente para que as ações de saúde mental tenham a mesma importância de outras ações/programas existentes na ESF, e que haja uma maior implicação dos profissionais nesse processo.

Vale ressaltar que a participação da equipe de Saúde da Família, ou equipe de referência, durante o AISM, é essencial para o cuidado longitudinal, bem como para a realização de encaminhamentos de acordo com a necessidade de cada caso, pois esses profissionais são conhecedores do seu território de atuação, das potencialidades e riscos que a comunidade apresenta, bem como dos usuários e das famílias que serão acompanhadas durante esse processo.

Este estudo contribuiu para evidenciar as potencialidades da AISM e ésugestivo para sua continuidade, uma vez que elucida os seus potenciais e sinaliza os desafios, os quais podem ser superados.

\section{Referências}

BORGES, C.C.; CARDOSO, CL.; A Psicologia e a Estratégia Saúde da Família: compondo Saberes e Fazeres. Revista Psicologia e Sociedade, v.17, n.02, p.26-32, mai-ago 2005.

BRASIL. Conselho Nacional de Saúde. Resolução n. 466/2012. Diretrizes e Normas Regulamentadoras de Pesquisas Envolvendo Seres Humanos. Brasília, 2012.

BRASIL. Ministério da Saúde. Disponível em: http:// portalsaude.saude.gov.br/portalsaude/area/342/acoes-eprogramas.html. Data de Acesso: 03 ago 2013.

DELFINI, P.S.S.; SATO, M.T.; ANTONELI, P.P.; GUIMARÃES, P.O.S.; Parceria entre CAPS e PSF: o desafio da construção de um novo saber. Revista Ciência e Saúde Coletiva, v.14, n.01, p.1483-1492, 2009.

FERTIG, A.; BRAGA, F.S.;WITT, R.R.; A percepção do usuário da atenção primária sobre o acolhimento em unidade de saúde da família. Revista de Enfermagem. v.09, n.09, p.0113, 2013.

FRANCO, T.B.; BUENO, W.S.; MERHY, E.E. O acolhimento e os processos de trabalho em saúde: Betim, Minas Gerais, Brasil. Cad. Saúde Pública, v.2, n.15, p.345-53, 1999.

GODOY, A.S.; Introdução à pesquisa qualitativa e suas possibilidades. Revista de Administração de Empresas. São Paulo, v.35, n.2, p. 57-63, abril/1995.

LIVALTER, A.L.A. Saúde Mental na Estratégia Saúde da Família: processos de trabalho na trilha do acesso e cuidado. Sobral, CE, 2012.

MEDEIROS, F.A.; SOUZA, G.C.A.; BARBOSA, A.A.A.; COSTA, I.C.C.; Acolhimento em uma Unidade Básica de Saúde: a satisfação do usuário em foco. Revista Salud Pública, v.12, n.03, p.402-413, jun/2010.

MINAYO, M.C.S. O desafio do conhecimento: pesquisa qualitativa em saúde. 8ed. São Paulo: Hucitec, 2004.

MORAIS, A.P.P.; TANAKA, O.Y. Apoio Matricial em Saúde Mental: Alcance e Limites na Atenção Básica. Revista Saúde e Sociedade. São Paulo, v.21, n.01, p.161-170, 2010

SALVADOR, A.S.; MEDEIROS, C.S.; CAVALCANTI, P.B.; CARVALHO, R.N. Construindo a Multiprofissionalidade: um olhar sobre a Residência Multiprofissional em Saúde da Família e Comunidade. Revista Brasileira de Ciências da Saúde, v.15, n.03, p.329-338, 2011. 
SOUSA, M.L.T. Gestão, atenção e subjetividade em saúde mental: avaliando a integralidade do apoio matricial na atenção primária à saúde de Sobral. Sobral, CE, 2012.

TESSER, C.L.; NETO, P.P.; CAMPOS, G.W.S. Acolhimento e (des)medicalização social: um desafio para as equipes de saúde da família. Ciência e Saúde Coletiva. São Paulo, v.15, n.03, p.3515-3624, 2010.

TÓFOLI, L.F.; FORTES, S. O apoio matricial de saúde mental na atenção primária no município de Sobral, CE: o relato de uma experiência. Sanare, v.6, n.2, p.34-42, 2007.

\section{PROMOÇÃO DE SAÚDE AMBIENTAL NA ESTRATÉGIA SAÚDE DA FAMÍLIA}

Flávia Pinheiro da Costa Márcio Anderson Cardozo Paresque Adriano Ferreira Martins

\section{Introdução}

O movimento da Promoção de Saúde constituiuse, na década de 80 , com as crises do Estado em prover economicamente os custos da atenção médica e da sociedade em suportá-los, pois não atendiam mais as necessidades individuais e coletivas. (FREITAS, 2009) Ampliou-se, assim, a visão do processo saúde-doença explicado pela História Natural das Doenças, reagindo ao hospitalocentrismo e aos limites da abordagem médica predominante, com a emersão da Atenção Primária à Saúde, integrando perspectivas sociais, físicas, políticas e econômicas para o alcance do bem-estar das comunidades.

A Carta de Ottawa tornou-se referência básica e fundamental para o desenvolvimento das concepções de promoção da saúde, trazendo como um dos campos centrais de ação a criação de ambientes favoráveis à saúde. 
No Brasil, no ano de 2006, a Política Nacional de Promoção de Saúde trouxe o ambiente, dentre outros determinantes e condicionantes, como produtor de qualidade de vida e redutor de vulnerabilidade e riscos à saúde. (HAESER; BUCHELE; BRZOZOWSKI, 2012)

Neste sentido, esforços vêm sendo realizados para procurar compreender e definir como o ambiente afeta a saúde, sendo que Franco Netto $(2009$, p.54) aponta que esse meio "é responsável por pelo menos $5 \%$ da carga de cada doença". O ambiente, então, é compreendido como fonte primária de promoção da saúde, quando estabilizado, assim como um integrante do processo gerador das doenças que afetam a população, pois a qualidade de vida humana produz-se por componentes intrínsecos e extrínsecos ao indivíduo.

Para esse estudo, o conceito de ambiente será entendido como o descrito por Dulley (1994), segundo o qual o ambiente é definido como o conjunto dos meios ambientes de todas as espécies pensados e/ou conhecidos pelo sistema social humano, ou seja, o ambiente composto pelo meio ambiente humano e o meio ambiente das demais espécies conhecidas. Dessa forma, quando se fala em ambientes geradores de saúde e doença, refere-se aos elementos inter-relacionados indispensáveis para a sobrevivência de diversas espécies - inclusive a humana, contidos nesses ambientes.

Apesar dos problemas ambientais serem de escala regional, a maioria deles é de índole local e têm repercussão direta na saúde das comunidades onde se originam. A Estratégia Saúde da Família (ESF), ao ser concebida, não deu ênfase às questões ambientais, embora tenha sido estruturada em um período de intenso debate mundial sobre o tema. (SILVA; ANDRADE, 2013)
Tendo surgido em 1994, como modelo reorientador da rede de assistência à saúde com base na Atenção Primária à Saúde, a Estratégia Saúde da Família (ESF) trabalha com a lógica da corresponsabilização do indivíduo/ família, ou seja, uma lógica diferencial na relação usuárioprofissional. (ROUQUARYOL; GURGEL, 2013) Fundamentase em princípios de universalização do acesso à população, integralidade da assistência e equidade, trazendo consigo uma nova maneira de fazer saúde, com destaque para a prevenção de doenças e promoção de saúde.

Documentos oficiais editados pelo Ministério da Saúde que normatizam a ESF, como o Guia Prático do Programa Saúde da Família (BRASIL. MINISTÉRIO DA SAÚDE. DEPARTAMENTO DE ATENÇÃO BÁSICA, 2001) e a Política Nacional de Atenção Básica (BRASIL. MINISTÉRIO DA SAÚDE. DEPARTAMENTO DE ATENÇÃO BÁSICA, 2011), afirmam que ações com enfoque ambiental devem compor as atividades a serem realizadas pelas equipes: "Das equipes de saúde da família, espera-se o conhecimento da realidade, a identificação de problemas sanitários e socioambientais da sua área de abrangência para melhor elaboração do planejamento local." (MENDONÇA; GIATTI; TOLEDO, 2012, p.777)

A questão da promoção da saúde ambiental é algo que deve ser incorporado à promoção de saúde da população, com práticas de cuidados ambientais, visto que "a situação ambiental configura-se num processo de contínua degradação, podendo ser observado pela permanência de certas doenças infecto-parasitárias decorrentes da falta de infraestrutura urbana." (COHEN et al., 2004, p.808) Como exemplo estão as doenças diarréicas agudas, que se apresentam constantemente nos territórios, mesmo com os esforços realizados em seu combate. 
Os atores que operacionalizam a ESF devem estar sensibilizados, reflexivos e atuantes quanto às ações de saúde ambiental nas suas vivências. Por exemplo, os profissionais de saúde percebem a ligação entre a situação ambiental do território e a saúde/doença da população adscrita a ela? Contemplam, em sua atuação profissional, práticas voltadas à promoção da saúde ambiental?

Faz-se necessário conhecer, portanto, como essas questões aparecem em um território e a forma como a ESF organiza-se para fortalecer tais práticas, potencializar atores e incorporar tarefas importantes para a promoção da saúde ambiental da comunidade, na perspectiva de assegurar a integralidade do cuidado com indivíduos e coletivos no SUS.

O interesse pelo tema em questão despontou com as graduações anteriores da autora em Enfermagem e Tecnologia em Saneamento Ambiental, que contribuíram para conhecer a conexão saúde-ambiente, visto como precursora para o alcance de promoção da saúde e prevenção de doenças e agravos. Também assim, com as práticas e reflexões vividas durante a Residência Multiprofissional em Saúde da Família, foi possível corroborar a concepção de atenção integral dos sujeitos e do impacto dos condicionantes ambientais na produção de saúde das comunidades.

Objetivou-se compreender a promoção de saúde ambiental no território do Centro de Saúde da Família Alto da Brasília, em Sobral/CE. Buscou-se, para isso, descrever a situação do saneamento ambiental desse local e das doenças diarréicas agudas - entendidas como problemas de saúde intrinsecamente ligadas a essa condição - e conhecer como os ACSs percebem as relações e as práticas de saúde ambiental.

\section{Metodologia}

Os objetivos do estudo levaram à abordagens quanti e qualitativas, que embora tenham concepções distintas, não são divergentes. Minayo (2008) considera que a experiência de trabalho com as abordagens quantitativas e qualitativas mostra que uma investigação de cunho quantitativo pode ensejar questões passíveis de serem respondidas só por meio de estudos qualitativos, trazendo-lhe um acréscimo compreensivo e vice-versa, e assim, promovem uma mais elaborada e completa construção da realidade.

Quanto à tipologia, a pesquisa caracteriza-se como analítica-descritiva, cujo aspecto analítico envolve o estudo e avaliação aprofundados de informações disponíveis na tentativa de explicar o contexto de um fenômeno, enquanto o descritivo procura determinar status, opiniões ou projeções futuras nas respostas obtidas. (THOMAS; NELSON, 2013)

O estudo realizou-se no município de Sobral, que se distancia 223,3 Km da capital do Estado, localizado na zona Centro-Oeste do Ceará, contando com uma área de 2.129,00 $\mathrm{km}^{2}$ e uma população estimada em 182.431 habitantes. (IBGE, 2013) É a principal cidade do noroeste cearense e a segunda mais importante do Estado em termos econômicos e culturais. Localiza-se sob as coordenadas geográficas $3^{\circ} 41^{\prime} 10^{\prime \prime} \mathrm{S}$ e $40^{\circ} 20^{\prime} 59^{\prime \prime} \mathrm{W}$ e em altitude de $69,49 \mathrm{~m}$. O clima de Sobral é tipicamente Tropical Quente Semiárido, com uma temperatura média de 26 a 28 graus centígrados e pluviosidade média de $821,6 \mathrm{~mm}$. (CEARÁ, 2013)

$\mathrm{Na}$ área da saúde, apresenta uma sólida estrutura e rede assistencial nos níveis de atenção à saúde. Conta com 74 unidades de saúde ligadas ao Sistema Único de Saúde, sendo 28 Centros de Saúde da Família (CSFs) divididos 
organizativamente em cinco macroáreas, além das demais referências da atenção secundária e terciária.

O CSF Alto da Brasília compõe a macroárea 5 e possui duas equipes mínimas de Saúde da Família, além do apoio do Núcleo de Apoio à Saúde da Família (NASF) e da Residência Multiprofissional em Saúde da Família (RMSF). Atende uma população estimada de 7.700 pessoas. Possui em sua área adscrita, além do bairro que dá nome à unidade, as localidades de Paraíso das Flores, Coração de Jesus, Betânia e Pedra Branca (esta última constitui a zona rural do território, distante $6 \mathrm{~km}$ da sede).

A coleta dos dados quantitativos se deu a partir de dois relatórios disponibilizados pelo município, a saber: Relatório do Sistema de Informação da Atenção Básica (SIAB) e Notificações de casos de Diarreias, encontradas no SINAN (Sistema de Informação de Agravos de Notificação).

As informações qualitativas foram coletadas através de um grupo focal com sete dos onze Agentes Comunitários de Saúde (ACS) da unidade, que aceitaram participar do momento. Mais do que um momento de perguntas e respostas, o grupo focal tem sua importância pelo valor do debate disparado por essa técnica de coleta. Segundo Neves e Domingues (2007, p.63), "os membros do grupo falam livre e espontaneamente sobre certo assunto, e tem o propósito de obter informações aprofundadas sobre conceitos e ideias de um grupo". Mediante autorização através do Termo de Consentimento Livre e Esclarecido, o grupo focal foi gravado para posterior análise.

O tratamento dos dados quantitativos ocorreu por análise descritiva, entendida como o estudo da variabilidade da frequência das doenças ao nível coletivo, em função de variáveis ligadas ao tempo, ao espaço e à pessoa. Barradas (1999) afirma que "a intenção da epidemiologia descritiva seria a de conhecer padrões gerais no comportamento de doenças e identificar subgrupos populacionais mais vulneráveis". Para os dados qualitativos, a técnica utilizada para o conhecimento das percepções dos ACSs foi a Análise de Conteúdo (MINAYO, 2008), onde parte-se de uma literatura de primeiro plano para atingir um nível mais aprofundado, aquele que ultrapassa os significados manifestos.

A pesquisa ocorreu no período de agosto de 2013 a fevereiro de 2014, o que corresponde ao início da elaboração do projeto até a apresentação da pesquisa.

\section{Resultados e discussões}

Com a análise dos dados coletados nos relatórios e as informações do grupo focal com as ACSs, foi possível determinar três categorias para discussão, descritas a seguir:

Saúde X Ambiente: Compreendendo a situação do território e a percepção dos ACS

No caso dos seres humanos, o seu meio ambiente mais comum são as cidades, que podem ser vistas como natureza modificada pelo homem (...), denominado também de meio ambiente construído. (...) Os sistemas sociais humanos afastam-se gradualmente do "natural", pois, por sua própria natureza, tem por objeto conhecê-la e modificá-la. (DULLEY, 2004, p.21)

Os conhecimentos e as mudanças, descritas na citação acima, trouxeram benefícios para o ser humano, que organizou no espaço e no tempo, diferentes sistemas necessários à sua sobrevivência. Essa interferência, por 
outro lado, também acabou por trazer desequilíbrios no meio ambiente das outras espécies e acarreta, a todo momento, diversas consequências negativas, dentre elas, o aparecimento de agravos e doenças. A interface entre ambiente e saúde vem se desenhando ao longo da evolução humana, e hoje é considerada como indissociável. As ACSs do estudo expressaram essa relação nas seguintes falas:

A relação é próxima, porque se ela cuidar do meio ambiente ela vai ter um melhor nível de vida, vai ter uma prevenção de doenças na vida dela e da família, agora se ela for uma pessoa que não cooperar, não ajudar a limpar e a proteger o meio ambiente, vai ter consequência de doença tanto pra ela como pra outras pessoa. (ACS 2)

Já eu acho assim... que pra cuidar do ambiente, ela tem que começar de casa, pra partir pra rua, pros vizinhos, pro Posto. (ACS 7)

Percebe-se que os entrevistados relacionaram as questões ambientais com a situação de saúde da população. Além disso, é notável que estejam ocorrendo mudanças gradativas sobre o modo como as pessoas veem os fatores ambientais dentro do contexto da produção de saúde e, principalmente, a relação desses com o aparecimento de doenças, quando em desequilíbrio.

Sena e colaboradores (2010, p.571) corroboram essa inter-relação entre saúde e ambiente, afirmando que "a visão socioambiental é vista como uma alternativa a ser utilizada para a identificação de melhores caminhos na direção da sustentabilidade da vida."

Outro ponto de destaque, nas falas dos sujeitos, pode ser visto na percepção sobre as diferentes exposições de risco às quais as pessoas estão sujeitas, no sentido de serem infectadas: no domicílio e em espaços extradomiciliares, o que Ribeiro e Rooke (2010, p.15) definem de "domínios públicos e domésticos". Para tais autores, essa distinção torna-se de grande importância porque cada um necessita de intervenções diferentes no seu controle, citando o exemplo das diarreias, que são transmitidas nos dois domínios.

Dessa forma, torna-se evidente a percepção dos sujeitos de que as condições do meio podem afetar a saúde da população. Entende-se como condições desse meio, tanto as condições de higiene nos domicílios como o saneamento do bairro onde vivem.

O acesso aos serviços de saneamento básicoé condição fundamental para a sobrevivência e dignidade humana. 0 déficit em saneamento básico traz consequências graves em termos de saúde pública, meio ambiente e cidadania. (GALVÃO JÚNIOR; PAGANINI, 2009) Em Sobral, no ano de 2013, o abastecimento público de água atingiu 91,74\% das famílias, aumentando cerca de dois pontos percentuais em relação a 2009, aumento similar visto nos demais componentes do saneamento básico: coleta pública do lixo, sistema de esgotamento sanitário, que chegaram a $82,3 \%$ e $66,3 \%$ das famílias do município, respectivamente. (SIAB, 2013)

No território analisado, mais de $96 \%$ das famílias possuem abastecimento de água por rede pública, porém, na localidade da Pedra Branca, esse tipo de abastecimento não chega a $30 \%$ das famílias, que recorrem a outros meios para obter a água, como poços/nascentes (aproximadamente $30 \%)$ e demais soluções alternativas (41\%).

Vale a pena destacar ainda, que cerca de $52 \%$ das famílias da zona rural não fazem nenhum tipo de tratamento domiciliar dessa água, mesmo com a disponibilidade 
do Hipoclorito de sódio 2,5\% no CSF, o que aumenta as possibilidades de contaminação e disseminação de doenças por veiculação hídrica. Sobre isso, Philipp Jr. e Martins (2005) afirmam que o controle e a vigilância realizada pelas Secretarias Estaduais e Municipais de Saúde não dispensam os cuidados necessários que a população deve ter.

Quanto aos resíduos sólidos, a área tem $94,5 \%$ do seu lixo recolhido pela coleta pública, situação oposta vista na área rural, onde cerca de $70 \%$ dos resíduos sólidos é disposto a céu aberto e $22 \%$ queimado ou enterrado, pois a população não conta com serviço público da coleta de lixo. Lagrotta e colaboradores (2008) apud Flausino, SouzaSantos e Oliveira (2011, p.226) apontam que "produtos industrializados podem contribuir para a dispersão e densidade de vetores no ambiente humano", uma vez que a disposição desses artefatos no ambiente aumenta o volume de lixo e favorece o estabelecimento de populações de animais indesejáveis.

Os esgotos gerados pelas residências têm sua maior parte recolhida pelo sistema público municipal de coleta e tratamento de águas residuais: $91 \%$ das famílias utilizamse desse sistema na área, excetuando-se, mais uma vez, a localidade da Pedra Branca, que tem $81,8 \%$ das famílias lançando os dejetos diretamente sobre o solo ou nos rios, criando, desse modo, situações favoráveis à transmissão de doenças devido à presença de matéria orgânica nos esgotos.

O maior número de casas em todas as localidades do território, por sua vez, é feita de tijolo, o que diminui consideravelmente a presença de vetores de doenças, mas ainda torna-se motivo de preocupação a localidade de Pedra Branca, que possui $46 \%$ das casas fabricadas de taipa, revestidas ou não.
Portanto, percebe-se grandes diferenças entres as áreas atendidas pelo CSF, constituindo-se um grande desafio para a equipe tanto na assistência quanto nas atividades de promoção da saúde da sua comunidade. No Brasil, o déficit do setor de saneamento básico é elevado, sobretudo no que se refere ao esgotamento sanitário, com maior carência nas áreas periféricas dos centros urbanos e nas zonas rurais, onde se concentra a população mais pobre (GALVÃO JÚNIOR; PAGANINI, 2009), situação claramente ilustrada nos dados descritos acima.

Situação das Doenças Diarreicas Agudas no território do CSF Alto da Brasilia

O gráfico a seguir (Gráfico 01) demonstra o número absoluto de casos de diarreias nos anos de 2009 a 2013, no município de Sobral e no Bairro Alto da Brasília.

\section{Gráfico 01 - Série Histórica de número de Casos de Diarreia em Sobral e no Bairro Alto da Brasília, nos anos de 2009 a 2013}

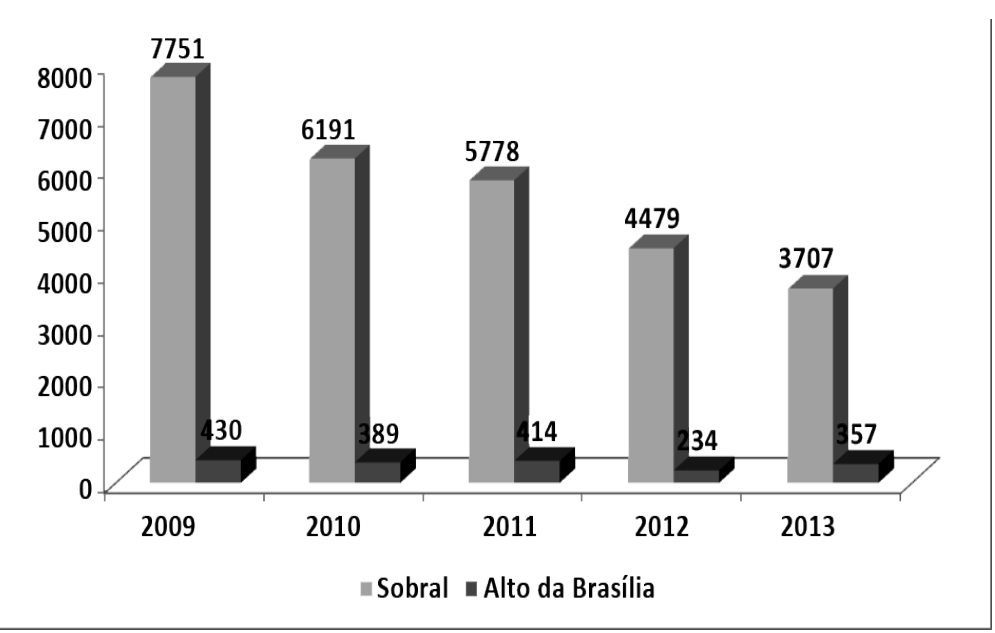

Fonte: SINAN (2013). Sobral, 2014. 
O ano de 2013 foi relativamente o maior em número de casos, do local em estudo em relação ao município, representando cerca de $10 \%$. Importante destacar a diminuição dos casos de diarreia ao longo dos anos no município, numa redução de 52\% no período de 2009 para 2013. Por outro lado, no bairro Alto da Brasília há oscilações no número de casos por ano, numa constância de 364,8 casos anuais, sem seguir a tendência do município.

Como já descrito anteriormente, as doenças diarreicas agudas têm suas causas existentes em diferentes domínios e a situação histórica em Sobral e na área em estudo devese aos cuidados de higiene e saneamento em cada um desses locais. Sobre isso, as falas das ACS convergiram principalmente para a falta de cuidados domiciliares, como visto na seguinte fala:

Às vezes, a casa é até de tijolo, mas a pessoa não cuida, não tem higiene, e acaba tendo diarreia mesmo, nas crianças mais ainda. (ACS 2)

As faixas etárias das crianças menores de 1 ano e das crianças de 1 a 4 anos representaram cerca de $27 \%$ de todos os casos de diarreia aguda do ano, sendo menor apenas que a faixa etária de 20 a 39 anos que, por sua vez, tem o maior intervalo de idade. Portanto, as crianças menores de cinco anos foram as mais afetadas pela doença, lembrando ainda, que algumas tiveram mais de um episódio de diarreia nesse período.

A tabela abaixo (Tabela 01) mostra o número absoluto e relativo de casos da doença por faixa etária, no ano de 2013:
Tabela 01: Número de casos absolutos e relativos das doenças diarreicas agudas, por faixa etária, no ano de 2013, na área adscrita do CSF Alto da Brasília.

\begin{tabular}{lll}
\hline Faixa Etária & No de casos & $\%$ \\
\hline$<1$ ano & 30 & 8,4 \\
1 a 4 anos & 66 & 18,4 \\
5 a 9 anos & 29 & 8,1 \\
10 a 19 anos & 46 & 12,9 \\
20 a 39 anos & 108 & 30,2 \\
40 a 59 anos & 50 & 14,1 \\
$>60$ anos & 28 & 7,9 \\
\hline Total & 357 & \\
\hline \multicolumn{2}{c}{ Fonte: SINAN (2013). Sobral, 2014. }
\end{tabular}

Para aprofundar mais a situação das crianças que tiveram a doença, o gráfico seguinte (Gráfico 2) mostra a quantidade de crianças, menores de dois anos, que moram no local do estudo, e tiveram diarreia, mais especificamente, quantas adquiriram a doença no âmbito da localidade da Pedra Branca, durante os meses de 2013. 


\section{Gráfico 2 - Número absoluto de crianças $<2$ anos que residem no Bairro Alto da Brasília, que tiveram diarreia, no bairro e na localidade de Pedra Branca, no ano de 2013.}

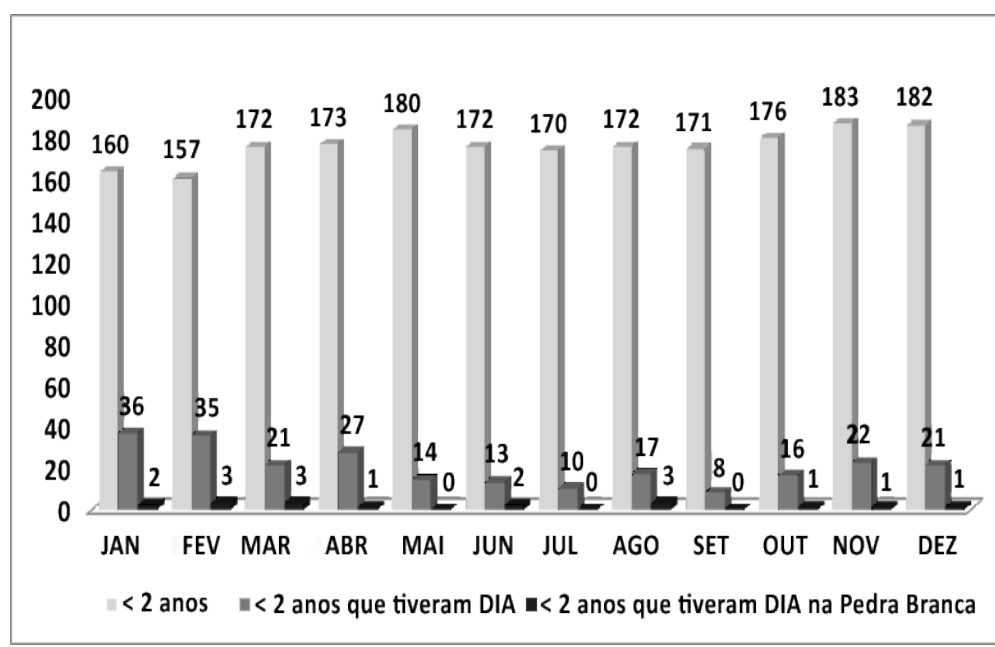

Fonte: SIAB (2013). Sobral, 2014.

Nota-se em primeiro lugar, o aumento considerável das diarreias no 1. o semestre, entre os meses de janeiro a junho, totalizando 146 casos (64\%) do ano inteiro de 2013, devido ao período da quadra invernosa. ${ }^{2}$ O mês com maior incidência de casos foi janeiro, com 36 crianças que tiveram a doença, e o menor foi setembro, com 08 casos registrados no Alto Brasília.

Quanto à situação da localidade de Pedra Branca, percebe-se a ocorrência de poucos casos em relação ao Alto da Brasília, com maior expressividade vista no mês de agosto, onde 3 das 17 crianças que tiveram diarreia são desta zona rural, equivalendo a $17,7 \%$ de menores de 02

\footnotetext{
2 No estado do Ceará, quadra invernosa corresponde ao período de quatro meses do ano (de janeiro a abril) em que, geralmente, há maior concentração de chuvas.
}

anos. No total, foram 17 casos registrados no ano, sendo 11 no primeiro semestre, contabilizando os mesmos $64 \%$ observados, nesse período, no bairro Alto da Brasília.

Resgatando-se o quadro 01, onde se tem a situação do saneamento básico das áreas atendidas no CSF Alto da Brasília e separadamente da Pedra Branca, pode-se inferir que nesta última área, o número de casos de diarreia não está relacionado diretamente ao saneamento básico inadequado, encontrado nessa zona rural. Em outras palavras, mesmo sem abastecimento público de água, sem coleta do lixo e dos dejetos, os casos registrados de diarreia seguem a mesma tendência no restante do bairro, que é provido de saneamento básico. Dessa forma, pode haver a possibilidade de que os cuidados domiciliares não estejam sendo realizados da forma esperada.

O estudo de Paz et al. (2013) aponta que o risco de ocorrência de diarreia em criança que vive em condições inadequadas de habitação e saneamento é quase 15 vezes maior do que entre aquelas que vivem em situações adequadas. Infere-se, portanto, que os dados podem não estar sendo corretamente informados, havendo uma possível subnotificação dos casos.

Processo de Trabalho das ACS na promoção da saúde ambiental

Questionadas sobre o seu trabalho na ESF, quanto à promoção da saúde ambiental, as ACSs afirmaram realizar atividades de orientação, tanto nos horários em que estão no CSF quanto nas áreas pelas quais são responsáveis. Tal relato pode ser comprovado no discurso abaixo: 
Além da orientação nas visitas domiciliares, na área, a gente trabalha também com palestras, oficinas, palestras educativas no acolhimento aqui na unidade. (ACS 1)

Silva e Andrade (2013) citam a atenção básica como nível de excelência para a inclusão da problemática ambiental e principalmente, a potencialização das práticas dos ACSs para esse fundamento.

O trabalho dos ACSs vem ao encontro de processos que envolvem seu papel ambíguo dentro do território: como morador e trabalhador da mesma área, espera-se um papel de mediador e de articulador entre o saber popular e o científico. No caso desse último, as atividades feitas a partir desse encontro tendem a ser mais eficazes, pois a comunidade percebe-se muito próxima ao ACS e encontrase mais aberta às suas orientações.

Ainda assim, foi relatada a dificuldade na realização dessas ações:

Mas é muito difícil, muitas pessoas a gente vai falar, eles não gostam, acham ruim, como teve um caso lá na minha área, que a mulher deixou de falar comigo, que eu fui orientar que olixo fazia mal, principalmente ela que tinha criança em casa. (ACS 7)

O Paulo Freire, que é um grande educador, ele fala sempre, a gente não conscientiza ninguém, a gente sensibiliza, é um processo lento, a gente tem que ter paciência, ir orientando pra que melhore, a gente vai tentando, vai criando estratégia. (ACS 4)

Como citado pela ACS, o processo de difusão de saberes e práticas constitui um desafio que cotidianamente os profissionais de saúde enfrentam. Formados em um modelo hierarquizado e tradicional de ensino, por vezes não sentem que há a reprodução de sua parte na forma de lidar com a comunidade. Essa por sua vez, não encontra sentido nas orientações que lhe são passadas, não sente seu saber valorizado, o que implica inúmeros desencontros entre esses atores.

A convivência cotidiana dos profissionais com a população, nos serviços de saúde, permite um contato muito próximo entre os vários atores envolvidos no processo educativo, permite um rico aprendizado dos caminhos de uma educação em saúde que respeite a autonomia e valorize a criatividade dos educandos. (VASCONCELOS, 2004, p.70)

O trabalho em saúde liga-se intimamente às interações entre os sujeitos, necessitando para tais relações, práticas de vínculo, humanização, comprometimento social e interdisciplinaridade, ao que Merhy (2002) denomina de tecnologia leve. Mais do que os instrumentos tecnológicos de trabalho, os saberes e ações humanas, ao nível das relações interpessoais, contribuem fortemente para a produção da saúde.

Sendo assim, mesmo com as dificuldades, os ACSs possuem caminhos no seu fazer para o fortalecimento das discussões e das práticas em saúde ambiental, ao utilizaremse das ferramentas das tecnologias leves na educação em saúde. 


\section{Considerações finais}

O estudo da situação das questões sanitárias e da percepção dos atores da ESF propiciou uma análise da condição da promoção da saúde do território, sob o ponto de vista dos cuidados ambientais.

As zonas urbana e rural do CSF Alto da Brasília apresentam disparidades em relação ao saneamento básico, requerendo da equipe da ESF estratégias diferentes em cada local. Apesar de não terem sido configuradas diferenças na ocorrência das diarreias agudas, essa ainda é uma doença preocupante, especialmente nas crianças abaixo de cinco anos de idade.

Foram encontrados, porém, profissionais sensibilizados e que relacionam o processo saúde-doença da comunidade com o meio ambiente onde vivem. Não obstante as dificuldades que enfrentam, conhecem seu fazer e envolvem e responsabilizam a comunidade com a qual trabalham. Potencializar os ACSs, nesse sentido, para a promoção da saúde ambiental, constitui-se numa das aberturas concretas para alcançar a saúde nos territórios.

As discussões sobre a temática saúde ambiental encontram-se aquém do necessário para a sua operacionalização, sendo preciso a realização de mais estudos nessa área para a mudança do quadro atual. Considera-se o saber interdisciplinar e o empoderamento da população caminhos importantes, juntos, na busca da integralidade do indivíduo e da sustentabilidade ambiental e continuação da vida.

\section{Referências}

BARRADAS, R.C.B. O Desafio das Doenças Emergentes e a Revalorização da Epidemiologia Descritiva. Informe Epidemiológico do SUS, v.8, n.1, p.7-15, 1999.

BRASIL. Conselho Nacional de Saúde. Resolução № 466/2012: Estabelece critérios sobre a pesquisa envolvendo seres humanos. Brasília (DF): Ministério da Saúde, 2012.

. Ministério da Saúde. Departamento de Atenção Básica. Guia Prático do Programa Saúde da Família. Brasília, DF, 2001.

. Ministério da Saúde. Portaria № 2.488, de 21 de outubro de 2011. Aprova a Política Nacional de Atenção Básica. Brasília: DF, 2011.

CEARÁ. Secretaria do Planejamento e Gestão. Instituto de Pesquisa e Estratégia Econômica do Ceará. Perfil Básico Municipal 2012: Sobral. Disponível em: <www.ipece.ce.gov. br> Acesso em: 15 nov 2013.

COHEN, S.C. et al. Habitação saudável no Programa Saúde da Família (PSF): uma estratégia para as políticas públicas e ambiente. Ciênc. saúde coletiva, Rio de Janeiro, v.9, n.36, set. 2004.

DULLEY, R.D. Noção De Natureza, Ambiente, Meio Ambiente, Recursos Ambientais E Recursos Naturais. Agric. São Paulo, São Paulo, v.51, n.2, p.15-26, jul./dez. 2004.

FLAUSINO, R.F.; SOUZA-SANTOS, R.; OLIVEIRA, R. M. de. Indicadores Socioambientais para Vigilância da Dengue em Nível Local. Saúde Soc. São Paulo, v.20, n.1, p.225-240, 2011. 
FRANCO NETTO et al. Impactos socioambientais na situação de saúde da população brasileira: Estudo de indicadores relacionados ao saneamento ambiental inadequado. Tempus. Actas em Saúde Coletiva, v.4, n.4, p.53-71. 2009.

FREITAS, C.M. de. A Vigilância da Saúde para a promoção da Saúde. In: CZERINA, D.; FREITAS, C.M. de. Promoção da Saúde: conceitos, reflexões, tendências. 2ed. Rio de Janeiro: Fiocruz, 2009.

GALVÃO JUNIOR, A.C.; PAGANINI, W.S. Aspectos conceituais da regulação dos serviços de água e esgoto no Brasil. Engenharia Sanitária e Ambiental, v.14, n.1, jan/mar 2009, p. 79-88.

HAESER, L.M.; BUCHELE, F., BRZOZOWSKI, F. S. Considerações sobre a autonomia e a promoção da saúde. Physis, Rio de Janeiro, v.22, n.2, p.605-620, 2012.

IBGE. Contagem da População 2010. Disponível em: <http://www.ibge.gov.br>. Acesso em: 03 ago 2013.

MENDONÇA, R.C.; GIATTI, L.L.; TOLEDO, R.F.de. A Temática Ambiental em Representações e Práticas de Profissionais de Saúde da Família no Município de Manaus - AM/Brasil. Saúde Soc. São Paulo, v.21, n.3, p.776-787, 2012.

MINAYO, M.C.S. O Desafio do Conhecimento: pesquisa qualitativa em saúde. 11ed. São Paulo: HUCITEC, 2008.

NEVES, E.B.; DOMINGUES, C.A. Manual de metodologia da pesquisa científica. Rio de Janeiro: EB/CEP, 2007.

PAZ, M.G.A. et al. Prevalência de diarreia em crianças e condições de saneamento e moradia em áreas periurbanas de Guarulhos, SP. Rev Bras Epidemiol, v.15, n.1, p.188-97, 2012.
PHILIPPI JR, A.; MARTINS, G. Águas de Abastecimento. In: PHILIPPI JR, A. Saneamento, Saúde e Ambiente: Fundamentos para um desenvolvimento sustentável. Barueri: Manole, 2005.

RIBEIRO, J.W.; ROOKE, J.M.S. Saneamento Básico e sua Relação com o Meio Ambiente e a Saúde Pública. 36p. Monografia (Curso de Especialização em Análise Ambiental), Faculdade de Engenharia da UFJF, Juiz de Fora/MG, 2010.

ROUQUARYOL, M.Z.; GURGEL, M. Epidemiologia e Saúde. 7ed. Rio de Janeiro: Medbook, 2013.

SENA, J. et al . Uma prática pedagógica através das racionalidades socioambientais: um ensaio teórico da formação do enfermeiro. Texto contexto de Enfermagem, Florianópolis, v.19, n.3, Sept. 2010.

SIAB. Sistema de Informação da Atenção Básica. Sobral, 2013

SINAN. Sistema de Informações de Agravos de Notificação. Sobral, 2013.

SILVA, N.C.; ANDRADE, C.S. Agente comunitário de saúde: questões ambientais e promoção da saúde em comunidades ribeirinhas. Trabalho Educação e Saúde, v.11, n.1, Rio de Janeiro, Jan-Abr/2013.

THOMAS, J.R.; NELSON, J.K. Tipos de Pesquisa considerando os Procedimentos Utilizados. Disponível em: <www. ergonomia.ufpr.br/TiposdePesquisa.pdff/ Acesso em: 1 ago 2013.

VASCONCELOS, E.M. Educação Popular: de uma prática alternativa a uma estratégia de gestão participativa das políticas de saúde. Physis, Rio de Janeiro, v.14, n.1, p.67-83, 2004. 


\section{SATISFAÇÃO PROFISSIONAL DO AGENTE COMUNITÁRIO DE SAÚDE NA ESTRATÉGIA SAÚDE DA FAMÍLIA}

Liduina Joyce Prado Linhares Andréa Carvalho Araújo Moreira Maria Michelle Bispo Cavalcante Thamyrys Prado Linhares

Introdução

A Estratégia Saúde da Família (ESF) surgiu como uma tentativa de transformar as práticas da atenção à saúde e o trabalho dos profissionais que nela atuam, tendo como finalidade, além de descentralizar a atenção na saúde e dar ênfase à integralidade das ações, enfocar o indivíduo como um sujeito integrado à família e à comunidade. (JARDIN; LANCMAN, 2009)

Para que os princípios do Sistema Único de Saúde (SUS) sejam efetivados na Atenção Primária à Saúde, é necessário que a equipe de Saúde da Família seja formada no mínimo por: um Médico, um Enfermeiro, um ou dois Auxiliares de Enfermagem, Cirurgião-Dentista, Auxiliar ou Técnico de Saúde Bucal e Agentes Comunitários de Saúde (ACS). Além desses, demais profissionais do Núcleo de Apoio à Saúde da 
Família (NASF) têm sido incluídos na equipe. (FIGUEIREDO et al., 2009)

Nesse sentido, destaca-se o ACS como um profissional de extrema significância no sistema de saúde brasileiro por estabelecer o primeiro contato com a família e a comunidade, bem como por garantir o acompanhamento do estado de saúde da população. (SOSAl et al., 2010) Esse profissional foi precursor da ESF quando, em 1991, o Ministério da Saúde criou o Programa de Agentes Comunitários de Saúde (PACS). A partir de 1999, o Decreto n.o 3.189 reafirmou que o trabalho do ACS era importante para a saúde no Brasil, mas somente em 2002 foi criada e regularizada a profissão, por meio da Lei Federal n. 10.507. (BRASIL. PRESIDÊNCIA DA REPÚBLICA, 2002)

Historicamente, o ACS representa uma ligação entre a equipe do CSF e a comunidade, por conviver com a realidade do bairro onde mora, trabalhar e ser formado a partir de referenciais biomédicos, tornando-se um interlocutor dos diálogos entre saberes e práticas, podendo ser um facilitador nessa mediação. (SANTOS, 2013)

Esses profissionais atualmente são amparados pela Lei $n$. .11 .350 , de 5 de outubro de 2006, que dispõe sobre suas atividades laborais, as quais são: o emprego de instrumentos para diagnóstico demográfico e sociocultural da comunidade; a realização de ações de promoção, prevençãoe de educação em saúde; o estímuloà participação da comunidade nas políticas públicas; a prática de visitas domiciliares e a participação em ações que fortaleçam os elos entre o setor saúde e outras políticas que promovam a qualidade de vida. (BRAND et al., 2010)

Essa gama de atividades realizadas pelo ACS tem proporcionado um campo privilegiado de produção de tecnologias relacionais, através da vinculação e proximidade com a comunidade. $\mathrm{O}$ uso de tecnologias ditas leves tem uma importância para a efetivação do trabalho desses profissionais, pois são produzidas no trabalho vivo em ato e condensam em si as relações de interação e subjetividade, possibilitando-lhes produzir acolhimento, vínculo, responsabilização e autonomia. (FERRI et al., 2007)

Observa-se que são delegadas a esses trabalhadores múltiplas tarefas com um alto grau de exigência, para as quais dependem do ambiente e da organização do trabalho visando realizá-las, e caso essas tarefas não obtenham a aprovação esperada podem levar à insatisfação do profissional, afetando assim, a qualidade da assistência prestada. (FIGUEIREDO et al., 2009)

Muitas vezes, diante do grande número de atribuições e devido ao fato de trabalharem no local em que habitam, esgotam-se suas habilidades para gerir o tempo, logo, face à excessiva demanda de tarefas, às críticas, à incompletude de seu trabalho e ao cansaço físico, pode surgir a frustração. (JARDIN; LANCMAN, 2009)

A vivência da autora principal deste trabalho, como fisioterapeuta da Residência Multiprofissional em Saúde da Família de Sobral - CE, permitiu identificar essa realidade, onde foi observado um número significativo de atribuições delegadas a esses profissionais, bem como a indignação desses trabalhadores diante da desvalorização profissional e sobrecarga de tarefas, fatos que geraram manifestações públicas em busca de melhores condições de trabalho.

Pode-se destacar que o autocuidado e a valorização profissional dos ACS são considerados elementos essenciais para que ocorra a motivação no trabalho, a qual, além de necessária à promoção da sua saúde física e emocional, servirá de impulso para o desenvolvimento de uma assistência de qualidade à comunidade atendida, pois um profissional valorizado produz um trabalho eficaz. (GAVALOTE et al., 2011) 
Mesquita, Moreira e Neto (2013) definem a satisfação no trabalho como sendo correspondente ao grau de contentamento do indivíduo com sua chefia, colegas, salário, promoções e tarefas realizadas considerando que os aspectos afetivos existentes na relação do sujeito com a organização é o que o leva à reação positiva ou negativa com o seu trabalho.

Desse modo, a satisfação profissional está sujeita à influência de forças internas e externas ao ambiente de trabalho, podendo afetar a saúde física e mental do trabalhador, interferindo em seu comportamento. (ESPINDOLA; OLIVEIRA, 2009)

Este estudo teve como objetivo verificar a satisfação profissional dos ACS, que é de fundamental importância para a qualidade da assistência por eles prestada à população, uma vez que o processo de trabalho desses profissionais é parte primordial do mecanismo em saúde e requer estudos, ações e formulação de estratégias com vistas ao desenvolvimento de cuidados seguros e à valorização profissional. A pesquisa pretende evidenciar como esses profissionais estão sentindo-se em relação ao seu fazer, contribuindo, desta maneira, para identificação de fatores que possam interferir na qualidade do trabalho. Assim sendo, a área de gestão poderá beneficiar-se do estudo à medida que fizer uso dos resultados desta pesquisa para estabelecer estratégias de apoio aos ACS, com vistas a garantir condições de trabalho favoráveis, que impactem na motivação profissional.

\section{Metodologia}

A abordagem escolhida para o estudo foi a quantitativa, tratando-se de um estudo tipo transversal, na perspectiva de verificar a satisfação profissional dos agentes comunitários de saúde que trabalham na zona urbana do município de Sobral - CE.

A pesquisa foi desenvolvida nesse município que possui, atualmente, 411 Agentes Comunitários de Saúde distribuídos em 57 equipes de Saúde da Família. Na zona urbana, existem 42 equipes com 285 ACS e na zona rural são 15 equipes com 126 ACS. (SOBRAL, 2013)

As equipes de Saúde da Família de Sobral são apoiadas pelo NASF e por residentes em Saúde da Família que estão inseridos em 16 Centros de Saúde da Família (CSF) da sede. Desta forma, o povo recebe assistência multiprofissional que amplia as ações de prevenção, promoção, cura e reabilitação da saúde.

A população investigada foi constituída por 259 ACS que exercem suas funções há mais de um ano nos CSF localizados na zona urbana da cidade de Sobral - CE. Os CSF selecionados para a realização da pesquisa foram os que possuíam profissionais da Residência Multiprofissional em Saúde da Família atuando em suas equipes. Foram excluídos da pesquisa os profissionais que estivessem afastados de suas atividades e aqueles que, nesse período, não estivessem presentes nos territórios. Assim, participaram dessa pesquisa 140 profissionais, pois foram excluídos do estudo: seis ACS, por motivo de afastamento do trabalho; dez em licença maternidade; vinte e cinco de férias; sessenta e sete porque não compareceram no dia da coleta de dados e onze que se recusaram a participar da amostra. 
A pesquisa ocorreu no período de dezembro 2013 a janeiro de 2014, sendo realizada nos seguintes territórios: Estação, Tamarindo, Coelce, Junco, Expectativa, Padre Palhano, Sumaré, Recanto, Uva, Caic, Vila União, Terrenos Novos, Coab II, Sinhá Sabóia, Pedrinhas e Dom Expedito. Para o desenvolvimento da pesquisa, o projeto foi apresentado aos gerentes dos CSF's, após entramos em contato com eles e explicamos como ela estava estruturada, deixando inclusive, já marcado um dia na semana para que tivéssemos o contato com os ACS.

Os encontros com os ACS ocorreram nas rodas dos CSF que acontecem geralmente às quintas-feiras, semanalmente. $\mathrm{Na}$ ocasião, foi explicado o assunto da pesquisa, bem como os objetivos da investigação e os aspectos éticos que envolvem a pesquisa com seres humanos, como a garantia da confidencialidade, do anonimato, da não utilização das informações em prejuízo dos indivíduos, do emprego das informações somente para os fins previstos na pesquisa e do retorno indireto dos possíveis benefícios obtidos através deste estudo. Após a aceitação verbal, o termo de consentimento foi assinado, constituindo-se de condição essencial para a participação no estudo.

A coleta de dados foi realizada utilizando-se um questionário contendo variáveis agrupadas em perfil socioeconômico e profissional com aplicação da Escala de Satisfação no Trabalho. (GODIN; SIQUEIRA, 2004)

Essa Escala é composta por cinco dimensões: satisfação dos colegas (itens 3, 5, 9, 15 e 25); salário (itens 8, $18,19,20$ e 21 ), chefia (itens $2,6,14,17$ e 22 ), natureza do trabalho (itens $1,7,10,13$ e 16) e promoções (itens 4, 11, 12,23 e 24); cada uma com cinco itens, num total de vinte e cinco perguntas, sobre diversas situações que medem o grau de satisfação no trabalho. A escala de resposta compreende sete pontos onde 1 (um) refere-se a um sujeito totalmente insatisfeito; 2 (dois) muito insatisfeito; 3 (três) insatisfeito; 4 (quatro) indiferente; 5 (cinco) satisfeito; 6 (seis) muito satisfeito; e 7 (sete) totalmente satisfeito. (GODIN; SIQUEIRA, 2004) Esse estudo excluiu a dimensão da promoção por não fazer parte da realidade da carreira de trabalho do ACS.

Para a obtenção dos dados, o cálculo de cada escore foi obtido somando-se os valores assinalados pelos respondentes em cada um dos itens que integra cada dimensão e tirada a média, depois, dividindo-se esse valor pelo número de itens da dimensão (que são cinco). A interpretação dos resultados considerou que quanto maior fosse o valor do escore médio, maior o grau de contentamento ou satisfação do empregado com aquela dimensão de seu trabalho. Sendo assim, os valores entre 5 e 7 tendiam a indicar satisfação, entre 1 e 3,9 insatisfação e valores entre 4 e 4,9 tendiam a indicar indiferença.

Os dados foram organizados em tabelas, conforme o perfil socioeconômico e profissional dos ACS; em seguida, foi analisado o grau de satisfação desses profissionais de acordo com a Escala de Satisfação no Trabalho referente a cada dimensão. Mediante pesquisas e estudos dispostos na literatura, foi possível aprofundar a análise dos dados sobre a satisfação profissional em foco.

A pesquisa trouxe riscos mínimos para os participantes tais como a frustração, pois contou somente com um questionário socioeconômico e a aplicação de Escala de Satisfação no Trabalho (GODIN; SIQUEIRA, 2004), precisando apenas de materiais como papel e caneta.

Esta pesquisa trouxe benefícios para os ACS, pois ofereceu subsídios para o planejamento e implantação de estratégias para melhorar a qualidade do trabalho desses profissionais. 


\section{Resultados}

Durante a pesquisa, analisamos os dados do perfil sociodemográfico, profissional e a escala de satisfação no trabalho.

\section{Perfil socioeconômico e profissional}

Na tabela 1 apresenta-se o perfil socioeconômico e profissional agrupado pelas seguintes variáveis: sexo, estado civil, idade, número de filhos, valor da renda, se tem casa própria e transporte, bem como os aspectos profissionais, tempo de serviço na atenção básica, graduação e educação permanente, tendo em vista a importância desses fatores para uma caracterização ampliada desses profissionais.

Tabela 1 - Perfil Socioeconômico e Profissional dos ACS de Sobral - CE, 2014.

\begin{tabular}{c|l|l}
\hline \multicolumn{2}{c|}{ Variáveis } & \multicolumn{1}{c}{ Frequência \% } \\
\hline \multirow{4}{*}{$\begin{array}{c}\text { Sexo } \\
\text { Civil }\end{array}$} & Feminino & 90,00 \\
\cline { 2 - 3 } & Masculino & 10,00 \\
\hline \multirow{4}{*}{} & Casado(a) & 48,57 \\
\cline { 2 - 3 } & Divorciado(a) & 6,42 \\
\cline { 2 - 3 } & Viúvo(a) & 3,57 \\
\cline { 2 - 3 } & União estável & 7,14 \\
\hline \multirow{4}{*}{ Idade } & 20 a 30 & 20,00 \\
\cline { 2 - 3 } & 30 a 40 & 45,00 \\
\cline { 2 - 3 } & $40 a 50$ & 31,43 \\
\cline { 2 - 3 } & 50 a 60 & 3,57 \\
\hline
\end{tabular}

\begin{tabular}{|c|c|c|}
\hline \multirow{3}{*}{$\begin{array}{c}\text { Número de } \\
\text { Filhos }\end{array}$} & Nenhum & 22,85 \\
\hline & 1 a 3 & 70,71 \\
\hline & 3 a 6 & 6,43 \\
\hline \multirow{3}{*}{ Renda } & 1 a 3 salários & 97,14 \\
\hline & 3 a 5 salários & 2,14 \\
\hline & mais que cinco salários & 0,72 \\
\hline \multirow{2}{*}{$\begin{array}{c}\text { Casa } \\
\text { própria }\end{array}$} & Possui & 64,28 \\
\hline & Não Possui & 35,42 \\
\hline \multirow{2}{*}{ Transporte } & Possui & 55,00 \\
\hline & Não Possui & 45,00 \\
\hline \multirow{3}{*}{$\begin{array}{l}\text { Tempo de } \\
\text { Serviço na } \\
\text { Atenção } \\
\text { Básica }\end{array}$} & 1 a 5 anos & 21,43 \\
\hline & 5 a 10 anos & 37,86 \\
\hline & mais de 10 anos & 40,71 \\
\hline \multirow{3}{*}{ Graduação } & Não Possui & 71,43 \\
\hline & Incompleta & 21,43 \\
\hline & Tem graduação & 7,14 \\
\hline \multirow{2}{*}{$\begin{array}{l}\text { Participa de } \\
\text { Educação } \\
\text { Permanente }\end{array}$} & Sim & 92,15 \\
\hline & Não & 7,85 \\
\hline \multirow{2}{*}{$\begin{array}{c}\text { Trabalha em } \\
\text { outro local }\end{array}$} & Sim & 14,29 \\
\hline & Não & 87,71 \\
\hline
\end{tabular}

Fonte: Autoria própria. 
No perfil sociodemográfico da população dos ACS analisada, pode-se observar que $90 \%$ são do sexo feminino; e apenas $10 \%$, do sexo masculino. Com relação ao estado civil, a maioria é casada, compreendendo uma porcentagem de $48,57 \%$.

A faixa etária com maior frequência é compreendida entre os 30-40 anos (45\%); e a de menor frequência (2,57\%), com idades entre 50-60 anos. Com relação ao número de filhos, $70,71 \%$ deles possuem de 1 a 3 filhos.

Foi observado que a renda dos ACS está compreendida entre 1-3 salários mínimos, valor contemplado por $97,14 \%$ dos respondentes. Verificou-se no estudo, que a maioria $(85,71 \%)$ tem um único emprego e $14,29 \%$ deles indicaram trabalhar em outras instituições e como autônomos. Já em relação à casa própria, $64,28 \%$ possuem sua moradia e $55 \%$ deles têm transporte próprio.

Com relação ao perfil profissional, destaca-se dos entrevistados, quanto ao tempo de serviço na Atenção Básica, que $60 \%$ dos ACS têm mais de 10 anos de serviço. Em relação ao curso de graduação, é possível observar que a maioria não possui nível superior, cuja representatividade é de $71,43 \%$, seguida por nível superior incompleto com $21,23 \%$ e uma minoria que tem graduação $(7,14 \%)$. Subsequentemente, foi constatado que $92,15 \%$ deles participam de Educação Permanente.

\section{Análise da Escala de Satisfação do Trabalho}

Avaliou-se a satisfação no trabalho dos ACS, na qual foi verificada a satisfação em relação aos colegas, à natureza do trabalho, à chefia e ao salário, o que possibilitou conhecer como esses profissionais sentem-se em seu ambiente de trabalho e como é sua relação com a equipe em que estão inseridos.
Ao apresentar os dados sobre a satisfação no trabalho dos agentes de saúde entrevistados, mostram-se, na Tabela 2, os resultados referentes à dimensão Satisfação com os Colegas, que contempla o relacionamento, a colaboração, a amizade e a confiança mantidos com os colegas de trabalho. (GODIN; SIQUEIRA, 2004) Obteve-se o escore médio igual a 4,8 .

Tabela 2 Dimensão satisfação dos ACS com os colegas no município de Sobral - CE, 2014

\begin{tabular}{l|l}
\hline $\begin{array}{l}\text { 3. Com a confiança que eu posso ter em meus } \\
\text { colegas de trabalho }\end{array}$ & 4,50 \\
\hline $\begin{array}{l}\text { 5. Com a maneira como me relaciono com os meus } \\
\text { colegas de trabalho }\end{array}$ & 5,15 \\
\hline $\begin{array}{l}\text { 9. Com a quantidade de amigos que tenho entre } \\
\text { meus colegas de trabalho }\end{array}$ & 4,90 \\
\hline $\begin{array}{l}\text { 15. Com o espírito de colaboração dos meus colegas } \\
\text { 25. Com o tipo de amizade que meus colegas } \\
\text { demonstram por mim }\end{array}$ & 4,62 \\
\hline Resultado Geral & $\mathbf{4 , 7 9}$ \\
\hline
\end{tabular}

Fonte: Autoria própria.

É possível afirmar que os ACS estão indiferentes, considerando a dimensão citada. Quando se analisou por item, observou-se que a "confiança que posso ter em meus colegas de trabalho" foi o menor escore, com 4,5 e com maior escore o item que se refere ao relacionamento entre os colegas de trabalho, representado por 5,15.

A Tabela 3 trata da dimensão Satisfação com a Natureza do Trabalho, que é entendida como o contentamento com 
o interesse despertado pelas tarefas, com a capacidade delas de o absorverem, a variedade das mesmas (GODIN; SIQUEIRA, 2004), preocupações exigidas pelo trabalho e a oportunidade de fazê-lo.

Tabela 3 Dimensão satisfação dos ACS com a natureza do trabalho no município de Sobral - CE, 2014

\begin{tabular}{l|c}
\hline 1. Com a capacidade de meu trabalho me absorver & 4,71 \\
\hline $\begin{array}{l}\text { 7. Com a oportunidade de fazer o tipo de trabalho que } \\
\text { eu faço }\end{array}$ & 4,92 \\
\hline $\begin{array}{l}\text { 10. Com a variedade de tarefas que realizo } \\
\text { 13. Com as preocupações exigidas pelo meu trabalho }\end{array}$ & $\mathbf{3 , 8 1}$ \\
\hline $\begin{array}{l}\text { 16. Com o grau de interesse que minhas tarefas me } \\
\text { despertam }\end{array}$ & 4,95 \\
\hline Resultado Geral & $\mathbf{4 , 4 8}$ \\
\hline
\end{tabular}

Fonte: Autoria própria.

Foi identificado que os ACS estão indiferentes à natureza do trabalho desempenhado, uma vez que o escore médio foi 4,48. A menor pontuação, com 3,81 evidencia insatisfação dos profissionais mediante as preocupações exigidas pelo trabalho. $O$ item com maior pontuação, obtendo escore 4,95, foi a oportunidade de fazerem esse tipo de trabalho, sobre o qual os profissionais apresentaramse indiferentes também.

A terceira dimensão a ser analisada é a Satisfação com a Chefia, Tabela 4, que corresponde ao contentamento com a capacidade profissional do chefe, o tratamento e o entendimento entre eles, $o$ interesse pelo trabalho dos subordinados e o modo como coordena e organiza o trabalho. (GODIN; SIQUEIRA, 2004)

Tabela 4 Dimensão satisfação dos ACS com a chefia no município de Sobral - CE 2014

\begin{tabular}{l|l}
\hline $\begin{array}{l}\text { 2. Com a capacidade profissional do meu } \\
\text { coordenador }\end{array}$ & 5,09 \\
\hline $\begin{array}{l}\text { 6. Com a maneira como meu coordenador me trata } \\
\text { eu }\end{array}$ & 5,23 \\
\hline $\begin{array}{l}\text { 14. Com o entendimento entre meu coordenador e } \\
\text { 17. Com o interesse do meu coordenador pelo meu }\end{array}$ & 5,05 \\
\hline $\begin{array}{l}\text { trabalho } \\
\text { meu trabalho }\end{array}$ & 4,73 \\
\hline Resultado Geral & $\mathbf{4 , 9 4}$ \\
\hline
\end{tabular}

Fonte: Autoria própria.

O escore médio referente a essa dimensão foi 4,94 , obtendo um resultado geral de indiferença.

A análise dos itens, isoladamente, revelou que os agentes de saúde atribuíram maior pontuação à "maneira como meu coordenador me trata" com escore 5,23 verificando-se um caso de satisfação. Enquanto a menor pontuação, com escore 4,58, indica indiferença, relacionado ao modo como o coordenador organiza o trabalho.

A Tabela 5 demonstra a Satisfação com o Salário, especificamente, o contentamento com o salário recebido, comparado ao trabalho desempenhado, aos esforços feitos na realização do mesmo, à capacidade profissional e ao custo de vida. (GODIN; SIQUEIRA, 2004) 
Tabela 5 Dimensão satisfação dos ACS com o salário no município de Sobral - CE, 2014.

\begin{tabular}{l|l}
\hline $\begin{array}{l}\text { 8. Com a quantia de dinheiro que recebo no final do } \\
\text { mês }\end{array}$ & 3,29 \\
\hline \begin{tabular}{l} 
18. Com o meu salário comparado ao custo de vida \\
\hline $\begin{array}{l}\text { 19. Com o meu salário comparado com a minha } \\
\text { capacidade profissional }\end{array}$
\end{tabular} & 2,91 \\
\hline $\begin{array}{l}\text { 20. Com o meu salário comparado o quanto eu trabalho } \\
\text { 21. Com o meu salário comparado com os meus }\end{array}$ & 2,83 \\
\hline esforços no trabalho & 3,07 \\
\hline Resultado Geral & $\mathbf{3 , 0 0}$ \\
\hline
\end{tabular}

Fonte: Autoria própria.

O escore médio obtido foi de 3,0, que aponta uma insatisfação. Os itens que denotam maiores graus de insatisfação são, pela ordem, o salário: comparado à quantidade de trabalho $(2,83)$, à capacidade profissional $(2,87)$, comparado ao custo de vida $(2,91)$, aos esforços no trabalho $(3,07)$, à quantidade de dinheiro que recebe no final do mês $(3,29)$.

\section{Análise e discussão}

Os dados verificados nessa pesquisa refletem, de forma expressiva, a tendência da feminilidade na força do trabalho em saúde. Segundo Gavalote et al. (2011), a predominância de ACS do sexo feminino caracteriza a crescente feminilização da força de trabalho nos atos em saúde, que também está presente entre outras profissões. Esse perfil está pertinente com o papel de cuidadora que a mulher sempre desempenhou na sociedade, o que contribui para a sua maior credibilidade e sensibilidade perante a população assistida.

A faixa etária representa uma maior prevalência de adultos jovens. Acredita-se que os agentes comunitários de saúde com mais idade tendem a conhecer melhor a comunidade, ter mais vínculos, porém, eles também têm suas próprias considerações sobre o processo saúdedoença, podendo ser resistentes a novos conceitos relacionados à promoção da saúde em sua comunidade. Por outro lado, os agentes mais jovens não conhecem tão bem a comunidade e seu envolvimento pode ser menor, entretanto, seus conceitos de saúde e doença podem não ser muito aprofundados, estando mais abertos às transformações. (MOURA et al., 2010)

Nesse grupo profissional, as jornadas de trabalho podem levar ao cansaço físico, mental e ao desgaste emocional podendo acarretar doenças referentes ao estresse (MESQUITA; MOREIRA; NETO, 2013), o que é bem evidenciado, pois somente $14,29 \%$ dos ACS apresentam outro emprego.

Essa baixa porcentagem pode ser explicada devido à carga horária na Atenção Básica, que compreende turno integral e, além disso, em função da predominância da atuação feminina, sendo que o complemento profissional é adicionado ao doméstico compondo a chamada jornada total de trabalho. (SILVA; ROTENBERG; FISCHER, 2011) O estudo apresentou que $48,57 \%$ de ACS são casados e $76,93 \%$ têm filhos, fatos que ampliam os deveres e a responsabilidade pessoal. 
Este estudo demonstra também que a renda dos ACS abrange a faixa de 1 a 3 salários representando um baixo salário em comparação com o salário dos outros profissionais da saúde. Mesmo com essa baixa renda é interessante destacar que $64,28 \%$ possui casa própria e $55 \%$ deles têm transporte próprio.

A renda familiar dos ACS encontrada foi muito baixa, caracterizando-os como população de baixa renda e tendo uma inserção econômica muito semelhante à da população por eles assistida, demonstrando-se, ainda, que muitos deles têm um importante papel na sustentação econômica de suas famílias. Essa precarização do salário gera um sentimento de desvalorização do seu esforço e trabalho. (MOURA et al., 2010)

Quanto ao tempo de trabalho, foi encontrada uma baixa rotatividade desses trabalhadores, de modo que esse tempo torna-se importante, principalmente para o entendimento do papel do agente, que é construído em seu cotidiano laboral e no seu tempo de permanência e vínculo de contato com a comunidade e território. (FERRAZ; AERTS, 2009)

Em relação ao curso de graduação, destaca-se que para o exercício do cargo basta que o indivíduo tenha ensino fundamental completo (BRAND; ANTUNES; FONTANA, 2010), porém, os resultados apresentados mostram que a maioria dos ACSs apresentam nível de escolaridade superior àquele exigido pela lei.

Diante disso, pode-se concluir que a escolaridade é um processo que vem sofrendo transformações com o passar dos anos de existência desses trabalhadores do SUS. Mota e David (2010) relatam em suas pesquisas que quando surgiu o PSF $9,6 \%$ dos ACS possuíam apenas o ensino fundamental e atualmente esse índice é de $2,7 \%$, sendo o ensino médio o nível de instrução predominante. Considera-se, portanto, que quanto maior o grau de escolaridade, melhor condição terá esse profissional de incorporar conhecimento e guiar as famílias sob sua responsabilidade. (FERRAZ; AERTS, 2009)

Outro ponto importante observado é que esse trabalhadores, ao serem inseridos na ESF, participam de Educação Permanente, objetivando a superação de dificuldades e a melhor qualificação de sua prática em direção ao modelo proposto pelo Sistema Único de Saúde (SUS). Esse treinamento é de extrema importância, pois o objetivo das orientações aos familiares realizadas pelo ACS é a adequada utilização dos serviços de saúde. (BARBOSA; FERREIRA; BARBOSA, 2012)

O município também incentiva a realização de frequentes momentos de formação com os ACS, poiséatravés dela que esses profissionais ampliam seus conhecimentos, qualificam seu trabalho e tornam-se multiplicadores de informações dentro da comunidade, prestando assim, uma melhor assistência à população. A capacitação de recursos humanos para o SUS é questão fundamental para a política de saúde nos níveis de macro e micro gestão. Além disso, a ESF incorporou novos elementos para a reorientação do processo de trabalho em saúde, o que requer profissionais capazes de executar propostas inovadoras.

Nesse contexto, o uso de tecnologias em saúde como: o acolhimento, a produção de vínculo e a gestão compartilhada de processos de trabalho, contribuem para a reorientação das práticas nos serviços de saúde. Esses elementos compõem uma porção subjetiva do processo de trabalho, que está intrinsecamente ligado ao produto das relações dialógicas entre o trabalhador e o usuário. Através dessas relações, as equipes podem tomar consciência dos problemas na busca por melhorias na saúde da população. (PASSARENHA; CUNHA, 2009) 
Na análise da dimensão satisfação com os colegas, esses profissionais estão indiferentes em relação à colaboração, à confiança e até com a amizade entre os parceiros de trabalho. Nesse sentido, Mesquita, Moreira e Neto (2013) ressaltam que o trabalho em equipe emerge como modalidade de trabalho coletivo, que se configura na relação de respeito e confiança, em torno da qual deveria ocorrer essa integração no cotidiano.

Em pesquisa realizada por Peres et al. (2011), foi identificado que embora pareçam dicotômicos os aspectos que representam as fragilidades e facilidades do trabalho em equipe, na ótica dos ACS, há que se considerar que no mundo do trabalho da sociedade contemporânea os processos são dinâmicos e, portanto, oscilam entre estabilidade, contradição e antagonismo, exigindo das pessoas constante criatividade e capacidade de adaptação.

Quando se analisou por item, os indicadores, observou-se que a "confiança que posso ter em meus colegas de trabalho" apresentou insatisfação por parte dos respondentes; por outro lado, a questão que se referiu ao "relacionamento entre os colegas de trabalho" demonstrou satisfação.

Peres et al. (2011) relata em sua pesquisa que as facilidades que os ACS apontam para o trabalho em equipe referem-se à construção das relações interpessoais, que se expressam por meio da possibilidade de discussão dos problemas cotidianos, liberdade para falar, comunicação e diálogo, atitudes de respeito, linguagem comum, disposição para aprender, corresponsabilização e união. Tal construção, na ótica dos sujeitos entrevistados, é favorecida pela estratégia de reunião de equipe.

Diante do que foi abordado nesta pesquisa, é perceptivel que as relações interpessoais são boas e que, para serem concretizadas com eficácia, é necessário haver espaços para discussões e debates, possibilitando desta forma, que as pessoas juntas possam construir e trocar conhecimentos, compartilhando afetos e estreitando laços de amizades.

Já em relação à confiança nos colegas de trabalho foi observada a classificação pelo indicador indiferença e isso é preocupante, pois confiança entre os membros da equipe é importante, principalmente, devido ao caráter multiprofissional e à grande responsabilidade do tipo de trabalho desenvolvido, o qual abrange a saúde de cidadãos em nível individual e coletivo. Além do que, falta de confiança entre os membros da equipe pode trazer conflitos durante as atividades e, consequentemente, comprometer o relacionamento estabelecido entre os indivíduos, prejudicando o resultado do trabalho desenvolvido entre as partes. (VALENTIM; KRUEL, 2007)

Sobre a satisfação com o trabalho, foi identificado que os ACS estão indiferentes tanto em relação à natureza do que desempenham, quanto à oportunidade de o fazerem considerando a especificidade. Quando avaliados por escores encontram-se ainda, insatisfeitos mediante as preocupações exigidas pelo trabalho.

A dinâmica de trabalho dos Agentes Comunitários de Saúde é complexa, sendo o espaço em que eles vivem o mesmo em que atuam. As pessoas de sua realidade social são as mesmas a quem dirigem suas ações de cuidado e, assim sendo, esses trabalhadores vivenciam no seu cotidiano ações permeadas por um conjunto de sentimentos que oscilam da onipotência à frustração, os quais podem traduzir-se em sentimentos de prazer e sofrimento no trabalho. (BACHILI et al., 2008)

O ACS sente prazer no trabalho quando consegue solucionar os problemas dos usuários e ajudar as famílias, o que materializa sua ação, repercutindo positivamente 
na autoestima, satisfação e identidade profissional desses trabalhadores inseridos neste contexto laboral. (JARDIN; LANCMAN, 2009)

Quanto às situações geradoras de sofrimento no trabalho, podem ser destacadas as deficiências nos serviços de saúde que são: o desconhecimento das funções dos Agentes Comunitários de Saúde, a falta de reconhecimento, o sofrimento de trabalhar em equipe, a obrigatoriedade de morar e trabalhar no mesmo local, a convivência e envolvimento com os problemas sociais da comunidade e a exposição à violência e ao medo decorrente desse processo. (LOPES et al., 2012)

É importante observar que cada território tem suas particularidades, potencialidades e fragilidades que precisam ser reconhecidas e que influenciam diretamente no processo de trabalho tornando-o prazeroso ou cansativo.

Assim, é possível dizer que a satisfação e a insatisfação com o trabalho gerada no ACS está diretamente ligada ao papel que ele desempenha dentro da comunidade e ao reconhecimento desse, aliado ao fato de que a possibilidade de ser ACS confere-Ihe novas perspectivas, tanto no âmbito pessoal, como familiar e comunitário. (LOPES et al., 2012)

$\mathrm{Na}$ avaliação da dimensão da satisfação com a chefia também foi observada uma indiferença. Isso pode ser explicado devido ao fato de o município ter passado, há pouco tempo, por um processo seletivo onde ocorreram mudanças nos cargos da gerência, demonstrando, portanto, que a descontinuidade políticoadministrativa causa rupturas pela rotatividade de pessoal e fragiliza os vínculos com a comunidade, o que se reflete, negativamente, no processo de trabalho das equipes, pois além de comprometer a qualidade da assistência prestada, causa sofrimento aos trabalhadores envolvidos. (OLIVEIRA; CHAVES; NOGUEIRA, 2010)
Esse estudo demonstra que apesar de estarem satisfeitos com a forma como as gerentes os tratam, eles estão indiferentes com relação à forma como é organizado o trabalho, pois muitas atribuições que são exigidas para os ACS não estão inclusas no âmbito das suas funções, o que sobrecarrega o profissional e faz com que o trabalho não seja realizado de maneira eficaz, gerando insatisfação tanto para ele como para a população que assiste.

De acordo com Brito (2008), o trabalho prescrito refere-se ao que é esperado no âmbito de um processo de trabalho específico, com suas singularidades locais, estando esse vinculado à regras, objetivos fixados pela organização do trabalho e às condições que são dadas.

No entanto, no ato da execução das tarefas, o trabalhador depara-se com uma discrepância entre o que é pedido e o modo de colocar em prática. Na gestão desta defasagem está o chamado trabalho real. Segundo Brito (2008), o trabalho real ou atividade é a resposta dada pelos trabalhadores às imposições determinadas externamente que são, ao mesmo tempo, apreendidas e modificadas pela ação do próprio trabalhador, ou seja, é a forma como o trabalhador "faz" em um determinado processo de trabalho.

Atualmente, um amplo contingente de trabalhadores da área da saúde, ainda, desconhece a amplitude e a importância das ações realizadas pelos ACS. (GOMES et al., 2009) Isso é evidenciado em pesquisas realizadas por Lopes et al. (2012), onde esses profissionais relataram diversas situações de sofrimento relacionadas à falta de reconhecimento do seu trabalho e do não conhecimento de suas funções, gerando insatisfação e desmotivação no cotidiano laboral.

Neste estudo, o salário foi considerado o maior fator gerador de insatisfação por parte dos agentes de saúde, 
por não ser coerente com a responsabilidade e funções desempenhadas.

Segundo Santos et al. (2013), apesar da grande importância que o ACS assume dentro da equipe, incluindo o aumento significativo de trabalho e responsabilidade, é discrepante a diferença salarial entre os membros da mesma, sendo esse fator considerado um dos principais pontos negativos da profissão, logo, também de insatisfação revelada por eles, além da falta de estabelecimento claro das funções, da inexistência de um plano de carreira e da falta de reconhecimento e de valorização.

O tema salário é constantemente questionado devido principalmente aos desníveis salariais, pois o trabalho está ligado ao retorno financeiro, que é convertido em um local para morar e condições de sobrevivência, sendo esse um dos principais motivos de insatisfação da maioria dos profissionais.

É através do trabalho que se consegue realização e satisfação pessoal, a busca da felicidade, o preenchimento da vida com atos significativos para si e para os outros. Enfim, ele significa a identificação, o reconhecimento dentro do contexto social, a inclusão na sociedade como um indivíduo produtivo. (ROSENTOCK; SANTOS, 2011)

Finalizando, pode-se reafirmar a importância da atuação do Agente Comunitário de Saúde para a consolidação do SUS, bem como a necessidade de capacitação adequada e criação de estratégias de valorização e motivação para o exercício desta atividade laboral. (GOMES et al., 2009)

\section{Conclusão}

Essa pesquisa teve uma importância fundamental para que se pudesse conhecer o perfil sociodemográfico e profissional dos ACS, além de identificar como eles estão se sentindo no ambiente de trabalho em que estão inseridos.

Em relação à satisfação no trabalho, questão central do estudo, foi observado que os ACS encontramse indiferentes no que tange à relação com os colegas, a chefia e com a natureza do trabalho. É preocupante o fato de apresentarem essas restrições em relação ao espírito de colaboração, já que esses profissionais trabalham numa equipe multiprofissional. Tal informação evidencia a necessidade de mudanças ou utilização de fatores motivacionais durante o processo de trabalho, a fim de que seja adquirida a satisfação esperada.

Diante do exposto, torna-se relevante que os serviços de saúde busquem alternativas como o uso de tecnologias leves, para que se possam minimizar os fatores que contribuem para a desmotivação e criar estratégias de incentivo à valorização do profissional e à integridade da equipe, proporcionando condições favoráveis para os indivíduos trabalharem com eficácia e segurança, valorizando assim suas potencialidades e consecutivamente melhorando a qualidade da assistência prestada à população. O prazer do trabalhador torna-se um indicador da qualidade na prestação de serviço, visto que, quando esse está satisfeito, o indivíduo envolve-se e comprometese mais.

Vislumbra-se que a satisfação profissional só ocorrerá quando esse trabalhador sentir-se realizado em relação às suas expectativas, ou seja, quando sua remuneração estiver de acordo com aquilo que esperava obter, como: salário adequado, segurança no emprego, amizade, valorização e 
reconhecimento, além da oportunidade de trabalhar em equipe.

Assim, há necessidade de se repensar a gestão do trabalho no sistema de saúde brasileiro, revendo especialmente os fatores que implicam na satisfação profissional dos trabalhadores da equipe de Saúde da Família de um modo geral, e sobretudo, estabelecendo um sistema de avaliação de políticas nessa área.

Sobre a satisfação com o salário, os ACS caracterizaram-se insatisfeitos, situação bastante explícita nesta investigação. $O$ ápice da reclamação foi quanto ao salário, quando comparado aos esforços no trabalho. Foi observado, contudo, que o trabalho não supre apenas as necessidades financeiras, mas também as emocionais, por ser uma forma de satisfação, valorização e realização pessoal e profissional.

É importante, também, que o ACS busque obter informações acerca da satisfação profissional, pois, quando bem utilizada, torna-se ferramenta fundamental para incentivar o desenvolvimento das potencialidades da sua equipe, independentemente da instituição.

\section{Referências}

BACHILLI, R.G; SCAVASSA, A.J; SPIRI W.C. A identidade do agente comunitário de saúde: uma abordagem fenomenológica. Cienc Saúde Col, v.13, n.1, p.51-60. Jan./ Fev.2008.

BARBOSA, V.B.A; FERREIRA, M.L.S.M, BARBOSA, P.M.K. Educação permanente em saúde: uma estratégia para a formação dos agentes comunitários de saúde. Rev Gaúcha Enferm, v.33, n.1, p.56-63.Mar.2012.

BRAND, C.I.; ANTUNES, R.M.; FONTANA, R.T. Satisfações e insatisfações no trabalho do agente comunitário de saúde. Cogitare Enfermagem. v.15, n.1,p.40-47, Jan./Mar/2010.

BRASIL, Ministério da Saúde. O Programa de Agentes Comunitários de Saúde (PACS). Brasília: Ministério da Saúde; 2002.

BRITO, J.C. Trabalho prescrito. In: PEREIRA IB, LIMA JCF. Dicionário da educação profissional em saúde. 2.ed. Rio de Janeiro: EPSJV, 2008, 440p. Disponível: <http://www.epsjv. fiocruz.br/beb/textocompleto/008871>. Acesso em: 20 jan 2014.

ESPINDOLA, M.; OLIVEIRA, A. Análise Comportamental: um estudo de como o comportamento organizacional pode influenciar o clima organizacional de uma indústria. SynThesis Revista Digital FAPAM, 2009.

FERRI, S.M.N., et al . As tecnologias leves como geradoras de satisfação em usuários de uma unidade de saúde da família. Interface (Botucatu), Botucatu , v.11, n.23, dez/ 2007. 
FERRAZ, L.; AERTS, D.R.G.C. O cotidiano de trabalho do agente comunitário de saúde no PSF em Porto Alegre. Ciência \& Saúde Coletiva, v.10, n.2, p. 347-355, 2009.

FIGUEIREDO, I. M., et al. Qualidade de vida no trabalho: percepções dos agentes comunitários de equipes de saúde da família. Rev. Enfermagem, Rio de Janeiro, v.17, n.2,p.262-267.2009.

GAVALOTE, H.S.; PRADO, T.N.; MACIEL, E.L.N; LIMA, R.C.D. Desvendando os processos de trabalho do agente comunitário de saúde nos cenários revelados na Estratégia Saúde da Família no município de Vitória (ES, Brasil). Ciência \& Saúde Coletiva, v.16, n.1, p. 231-240.2011.

GODIM, S.M.G; SIQUEIRA, M.M.M. Emoções e afetos no trabalho. IN: Andrade, J.E; Bastos A.V.B;Zanelli, J.C. Psicologia, organizações e trabalho no Brasil. Porto Alegre, Artmed.2004.

GOMES, G.C; FILHO, W.D.L; ERDMANN, A.L. O sofrimento psíquico dos trabalhadores de UTI interferindo no seu modo de viver a enfermagem. Rev. Enfermagem, UERJ, v.14, n.1, p.93-99, 2006.

GOMES, K.O. et al. A práxis do agente comunitário de saúde no contexto do Programa de Saúde da Família: reflexões estratégicas. Saúde Soc. v.18, n.4, p.744-55, 2009.

JARDIN, T.A; LANCMAN, S. Aspectos subjetivos do morar e trabalhar na mesma comunidade: a realidade vivenciada pelo agente comunitário de saúde. Interface Comunic. Saúde Educ.v.13, n.28, p.123-135, 2009.

LOPES, D.M.Q. et al. Agentes Comunitários de Saúde e as vivências de prazer - sofrimento no trabalho: estudo qualitativo. Rev. esc. enferm. USP, São Paulo, v.46, n.3, Jun.2012.
MESQUITA, D.T; MOREIRA, A.C.A; Neto F.R.G. Satisfação profissional do gerente na Estratégia Saúde da Família. RAS , v. 15, n.59, Abr-Jun.2013.

MOTA, R.R.A; DAVID, H.M.S.L. A crescente escolarização do Agente comunitário de Saúde: uma introdução do processo de trabalho?.Trab.Educ.Saúde, Rio de Janeiro, v.8, n.2, p.229-248, jul./out.2010.

MOURA, M.S., et al. Perfil e práticas de saúde bucal do agente comunitário de saúde em municípios piauienses de pequeno porte. Ciênc. saúde coletiva, Rio de Janeiro, v.15, supl. 1, Jun. 2010.

OLIVEIRA, A.R. et al .Satisfação e limitação no cotidiano de trabalho do agente comunitário de saúde. Rev. Eletr. Enf. v.12, n.1, p.28-36, 2010.

PESSANHA R.V, CUNHA F.T.S. A aprendizagem-trabalho e as tecnologias de saúde na Estratégia Saúde da Família. Texto Contexto Enferm [online]. v.18, n.2, p.233-40,2009.

PERES C.R.F.B., et al. O Agente Comunitário de Saúde frente ao processo de trabalho em equipe: facilidades e dificuldades. Rev Esc Enferm, São Paulo.v.45, n.4, p. 905911, 2011.

ROSENSTOCK, K.I.V. Satisfação, envolvimento e comprometimento com o trabalho: Percepção dos profissionais na Estratégia Saúde da Família. 2011. 100f. Dissertação (Mestrado em Enfermagem) - Centro de Ciências da Saúde, Universidade Federal da Paraíba, João Pessoa, 2011.

SANTOS, K.T., et al. Agente comunitário de saúde: perfil adequado a realidade do Programa Saúde da Família? Ciênc. saúde coletiva, Rio de Janeiro, 2013. 
SILVA, A.A; ROTENBERG, L.; FISCHER, F. M. Jornadas de trabalho na enfermagem: entre necessidades individuais e condições de trabalho.Rev. Saúde Pública, São Paulo, v. 45, n. 6, Dec. 2011.

SOBRAL, Secretaria de Saúde e Ação Social. Relatório da Gestão 2013. Sobral-CE, 2013.

SOSSAI, L.C.F., et al. O agente Comunitário de Saúde (ACS) e a comunidade:Percepções acerca do trabalho do ACS. Ciênc. Cuid. Saúde, v.9, n.2, p.228-237, Abr./Jun.2010.

VALENTIM, I. V. L.; KRUEL, Alexandra Jochims. A importância da confiança interpessoal para a consolidação do Programa de Saúde da Família. Ciênc. saúde coletiva, Rio de Janeiro, v.12, n.3, Junho. 2007.

\section{SISTEMA DE INFORMAÇÃO DA RESIDÊNCIA MULTIPROFISSIONAL (SIREMU): TECNOLOGIA PEDAGÓGICA E DE GESTÃO NA FORMAÇÃO MULTIPROFISSIONAL EM SAÚDE DA FAMÍLIA}

Márcia Maria Santos da Silva Maria Socorro de Araújo Dias André Luis Façanha da Silva Maristela Inês Osawa Vasconcelos

\section{Formação profissional e tecnologias em saúde}

A Estratégia Saúde da Família (ESF) tem se mostrado um espaço privilegiado para disseminação de práticas de superação do modelo de atenção à saúde curativista, a partir da reorganização da atenção primária à saúde do país, superando o conceito restrito de saúde como ausência de doença. (BRASIL. MINISTÉRIO DA SAÚDE, 2002) Em decorrência disso, o desafio de considerar o indivíduo em sua totalidade e atuar na perspectiva da integralidade emerge trazendo a necessidade de profissionais que atuem numa perspectiva interprofissional, articulando saberes 
e práticas necessárias ao enfrentamento dos problemas, considerando os determinantes sociais de saúde que se apresentam.

A atual organização da formação e do trabalho em saúde salienta a fragmentação dos saberes em campos profissionais, promovendo a divisão social do trabalho e a dificuldade do trabalhador da saúde em compreender seu papel de agente mediador na relação entre os serviços públicos e as necessidades de saúde da população. Porém, pouco se avançou na superação da lógica cartesiana e tecnicista do ensino hoje ainda oferecido pelas escolas formadoras na área. (GIL, 2005; BRASIL. MINISTÉRIO DA SAÚDE, 2005)

Importa reconhecer, porém, que a formação profissional na saúde, a partir da Reforma Sanitária e implementação do Sistema Único de Saúde (SUS), passa por intensa ressignificação e assume contornos diferentes: ao invés do foco na transferência de recursos cognitivos e tecnológicos, busca-se a formação de sujeitos comprometidos com um projeto de saúde pública relacionado às concepções de cidadania, de qualidade de vida e de trabalho. Ceccim (2009, p.445) destaca a importância de formar "Profissionais detentores (...) de habilidades, conhecimentos e valores capazes de fazer funcionar um sistema de saúde relativo à vida de todas as pessoas, estando a qualidade de vida na antecedência de qualquer padrão técnico a aprender ou exercer."

A formação em serviço, regulamentada em 2007 pelo Ministério da Saúde, aparece como alternativa para refrear a fragilidade da educação nessa área e tem nas residências multiprofissionais uma estratégia orientadora da formação nesse sentido. A Residência Multiprofissional em Saúde, ao passo que tenta articular os conhecimentos adquiridos na formação inicial com os múltiplos determinantes que perpassam o cuidado à saúde da população, possibilita, através da interdisciplinaridade, múltiplas formas de perceber e intervir nos problemas de saúde, bem como ressignificar o fazer profissional. Assim, "apresenta-se como uma alternativa para promover a mudança da prática assistencial em saúde, capaz de favorecer o trabalho em equipe, as trocas efetivas de saberes e práticas e a construção de uma nova realidade de saúde para a população." (NASCIMENTO; OLIVEIRA, 2010, p.815)

Em Sobral, desde 1999, a formação pós-graduada na modalidade Residência Multiprofissional em Saúde da Família (RMSF) vem sendo desenvolvida com a finalidade de aproximar a formação profissional em saúde da realidade social e do trabalho no SUS, qualificando os profissionais para atuarem no sistema de saúde. Nesse sentido, o Programa de RMSF do município tem como macro objetivos: a construção de novas tecnologias na ESF e a sistematização do fazer multiprofissional e de núcleo com vistas à promoção da saúde.

A concepção de tecnologias em saúde, referenciada no Programa, ancora-se nas reflexões de Merhy (1998, p.03) ao analisar a existência de tecnologias materiais e não materiais no campo da saúde. $O$ autor refere que o trabalho em saúde circunscreve-se no campo relacional e depende do trabalho vivo em ato ou "o trabalho no momento em que este está produzindo". Por isso, identifica três tipos de tecnologias em saúde, a saber: as tecnologias duras, representadas pelos instrumentos já produzidos; as tecnologias leve-duras, simbolizadas pelos conhecimentos técnicos que têm uma dimensão mais estruturada (dura), mas também apresentam uma dimensão flexível (leve) referente ao modo como cada profissional utiliza tais conhecimentos; e as tecnologias leves, representadas pelo campo das relações (o agir entre profissional e usuário), 
fundamentais para a produção do cuidado. Advoga, ainda, que somente é possível qualidade na atenção à saúde com a oferta de um sistema que contemple os três tipos de tecnologias referidas.

Em pesquisa realizada junto à RMSF de Sobral, Silva (2014) verificou que o Programa tem produzido evidências de sua efetividade no Sistema Saúde Escola local. Ao tratar das contribuições que a RMSF agrega, o estudo revela a produção de tecnologias em saúde como grande colaboração. Neste sentido, a autora aponta que "[...] a Proposta Pedagógica da Residência (considerando o referencial teórico, a dialogicidade presente e a busca pela efetivação da práxis) é a mola propulsora na abertura para a produção de tais tecnologias." (SILVA, 2014, p.109) Dentre as contribuições da RMSF evidenciadas, observa-se a predominância das tecnologias leves desenvolvidas pelos residentes em suas atividades práticas nos territórios da ESF. Não obstante, a pesquisa refere também a implantação do Sistema de Informação da Residência Multiprofissional em Saúde da Família (SIREMU), enquanto tecnologia levedura, que tem contribuído na sistematização de dados e informações sobre a atuação dos residentes nos territórios.

O SIREMU foi implantado em 2011 e surgiu a partir da necessidade de informações complementares que apontassem as atividades desenvolvidas pelos profissionais residentes nos territórios de atuação. Tendo como parâmetro a concepção de Merhy (1998), observa-se que ele configura-se como tecnologia leve-dura produzida pela RMSF:

Há uma tecnologia menos dura do que os aparelhos e as ferramentas de trabalho e que está sempre presente nas atividades de Saúde, a qual denominamos levedura. É leve um saber que as pessoas adquiram e está inscrito na sua forma de pensar os casos de Saúde e na maneira de organizar uma atuação sobre eles; mas é dura à medida que é um saber fazer bem estruturado, bem organizado, bem protocolado, normalizável e normalizado. (MERHY, 1998, p.03)

Enquanto ferramenta pedagógica e de gestão, o SIREMU reúne dados originados das ações desenvolvidas pelos residentes, organizados de maneira informatizada, e que podem subsidiar o monitoramento e avaliação do serviço, a elaboração de indicadores para melhor análise, bem como a avaliação dos processos e resultados. (CHAGAS, 2012) É uma tecnologia de caráter inovador, tendo sido reconhecido nacionalmente esse aspecto em 2014, com a premiação em 1일 lugar no Concurso InovaSUS ${ }^{1}$.

Nosso estudo pretende compartilhar a experiência de criação dessa tecnologia, que tem como principal objetivo: sistematizar dados que contribuam na gestão e na condução pedagógica da RMSF. Assim, descreveremos, a seguir, as etapas de construção do SIREMU e teceremos algumas considerações sobre a experiência.

\section{O percurso metodológico}

Trata-se de um estudo do tipo relato de experiência, onde apresentamos a construção do Sistema de Informações da RMSF. A experiência foi realizada no município de Sobral/ $\mathrm{CE}$, tendo como cenário a RMSF, programa de formação desenvolvido pela Secretaria de Saúde de Sobral (através

\footnotetext{
InovaSUS é um concurso para premiação nacional de experiências no SUS, com os objetivos de identificar, valorizar e premiar experiências inovadoras implementadas pelas esferas municipais e estaduais.
} 
da EFSFVS) em parceria com a Universidade Estadual Vale do Acaraú.

O período de realização compreende os anos de 2011 a 2012, quando foram realizadas as etapas descritas a seguir.

Identificação da demanda: a partir das reflexões feitas pelo corpo docente da RMSF, verificamos a necessidade de um registro sistemático das ações desenvolvidas pelos residentes, que produzisse dados significativos para - Programa, colaborando para analisar a atuação dos profissionais e a contribuição para o Sistema Saúde Escola de Sobral.

\section{Desenho do projeto}

Definição do esboço da proposta: elencamos nossos principais objetivos com a criação do Sistema, assegurando que o papel deste correspondesse aos âmbitos administrativo, técnico e pedagógico. Definimos também as principais estratégias para o alcance dos objetivos propostos.

Elaboração das Fichas de Registro: construímos as chamadas Ficha W, sendo uma ficha específica para cada categoria contemplada no Programa (Educação Física, Enfermagem, Farmácia, Fisioterapia, Fonoaudiologia, Nutrição, Odontologia, Psicologia, Serviço Social e Terapia Ocupacional). As informações constantes nas fichas deveriam considerar: local, data, faixa etária, sexo e perfil dos usuários atendidos pelas categorias referentes aos problemas de saúde/sociais com base na territorialização, além das atividades desenvolvidas.
Elaboração do fluxo de dados: definimos a forma de armazenamento e compartilhamento dos dados, bem como o fluxograma de funcionamento do Sistema.

Captação de financiamento: buscamos uma parceria com um Projeto do Programa Pesquisa para o SUS (PP SUS), voltado para efetividade dos Programas de Residência, a qual viabilizou a implantação do Sistema. Também fizemos articulações com a Secretaria Municipal de Saúde, com vistas a assegurar o custeio da continuidade do Sistema, inclusive para manutenção da plataforma virtual.

Implantação do Sistema: Acompanhamos a equipe técnica na criação da plataforma Web SIREMU para armazenamento das informações e realizamos testes para verificar a funcionalidade da plataforma virtual, considerando facilidade de acesso, interação, layout, agrupamento de informações, dentre outros aspectos.

Formação sobre a utilização do sistema: Realizamos (com docentes, discentes e gestão da RMSF e da EFSFVS) oficinas de apresentação da plataforma Web SIREMU, das fichas W de todas as categorias e do fluxograma de funcionamento do Sistema.

Monitoramento e Avaliação: Sistematicamente realizamos encontros para monitoramento do Sistema, bem como tivemos um momento avaliativo, onde docentes e discentes expuseram as fragilidades e potencialidades percebidas, sendo elencadas as propostas para melhoria do Sistema.

Definição e efetivação dos ajustes para aprimoramento: Analisamos e definimos a exequibilidade das propostas trazidas, verificando os ajustes necessários ao aprimoramento do Sistema, tais como a elaboração de um documento instrutivo para a utilização desse recurso. 
Sistematização escrita: Registramos textualmente a experiência, como estratégia de continuidade do Sistema, em consonância com a proposta tecida ao longo do desenvolvimento dessa tecnologia. Tal sistematização favorece ainda, que a experiência seja replicada em outros cenários, contribuindo para a difusão de tecnologias em saúde.

\section{O SIREMU em evidência}

As experiências acumuladas das categorias das turmas de Residência, pesquisas sobre sistemas de informação local/nacional, o perfil dos atendimentos e as ações desenvolvidas pelos residentes, além do referencial da territorialização em saúde foram elementos norteadores na construção do Sistema, legitimado em momentos coletivos, com a presença de discentes, docentes e da coordenação do Programa.

Os residentes são os responsáveis pelo preenchimento sistemático de cada planilha, cujos dados são oriundos das atividades coletivas e atendimentos realizados por eles, em seus territórios, diariamente. Após esse registro, a planilha é entregue ao preceptor da respectiva categoria mensalmente. O preceptor, então, analisa os dados e os encaminha para a secretaria da EFSFVS, onde um técnico de sistema de informação armazena essas infomações no Websistema. Inseridos os dados, os docentes, a coordenação da RMSF e a direção da EFSFVS podem ter acesso a eles e solicitar relatórios, de forma sistemática. A figura a seguir ilustra esse fluxo de produção de dados e alimentação do SIREMU.
Figura 01 - Fluxograma do Web SIREMU da Residência Multiprofissional em Saúde da Família de Sobral/CE.

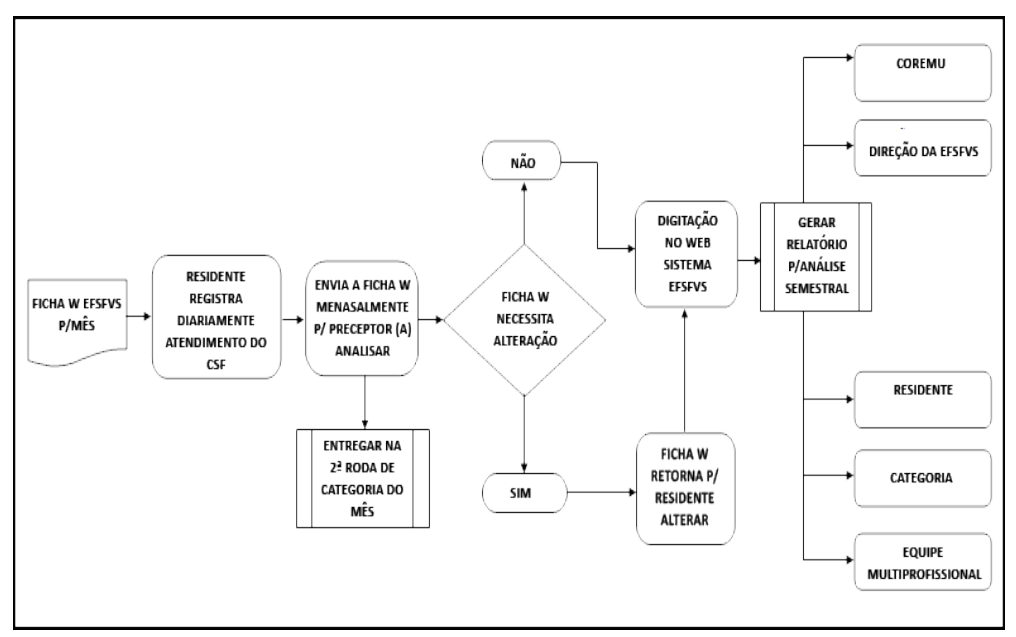

Fonte: Web SIREMU. Link: http://siremu.designmidiadigital.com/site/ logar.php

A partir das informações produzidas pelos relatórios e com a utilização de metodologias ativas, são realizadas análises por residente, por equipe multiprofissional, por categoria e por território de atuação, sendo possível obter dados que contemplam uma análise de efetividade do Programa, no que concerne às ações teórico-práticas desenvolvidas nos territórios de atuação. Além dessas análises nos espaços coletivos, é realizada uma abordagem de caráter formativo, sobre a atuação de cada residente, durante sua avaliação individual.

As informações geradas pelo Web SIREMU, provenientes das tecnologias leves utilizadas na organização dos serviços das equipes de residentes com demais profissionais das equipes de referência da Atenção Básica, desencadeiam o monitoramento de ações de matriciamento, tais como: Projeto Terapêutico Singular 
(PTS), compartilhamento de casos, intervisitas, intergrupos, educação permanente e intervenções na roda do Centro de Saúde da Família, ações coletivas, atividades de núcleo e articulação com a rede. Estas são ações que compõem o cotidiano do profissional residente e possibilitam a abordagem centrada na colaboração interprofissional, contemplando o cuidado na perspectiva da integralidade dos sujeitos.

As experiências de colaboração interprofissional trazem um aprendizado geralmente não disponível na graduação dos profissionais, em virtude da lacuna existente nos cursos de graduação, ao formar profissionais voltados para um trabalho nuclear, fragmentado. O conceito de colaboração interprofissional expressa uma integração de práticas voltadas para a solução de problemas específicos, trazendo princípios amplos como a interdisciplinaridade e seus desdobramentos na prática dos trabalhadores. (FURTADO, 2007)

Feuerwercker e Sena (1999) assinalam que, face às múltiplas dimensões do mundo, que se complementam, compreendê-lo exige um olhar que transcenda os limites disciplinares e apontam a interdisciplinaridade como uma estratégia de superação desse desafio. Acrescentam, ainda, na perspectiva da área da saúde, que: "A possibilidade de uma compreensão integral do ser humano e do processo saúde-doença, objeto do trabalho em saúde, passa necessariamente por uma abordagem interdisciplinar e por uma prática multiprofissional." (FEUERWERCKER; SENA, 1999, p.5)

Na prática da Residência, percebemos a constância do conceito de multidisciplinaridade e interdisciplinaridade, seja nas discussões do Programa, seja nos diálogos desencadeados nos territórios de atuação. No entanto, o desenho do Programa favorece o desenvolvimento de ações que coadunem com o viés interprofissional, em diversos espaços de atuação, e constatamos que as discussões advindas com o SIREMU têm provocado importantes contemplações sobre o termo e sua aplicabilidade na RMSF.

Além do campo de reflexões sobre o referencial teórico, o SIREMU traz uma singular contribuição no monitoramento, na avaliação e no planejamento do trabalho interprofissional e de núcleo. Destarte, o Web SIREMU tem produzido aprendizagens significativas, tais como: a compreensão acerca de matriciamento; a identificação das potencialidades e desafios do trabalho em equipe; a ressignificação da atuação de núcleo; e a autorreflexão sobre o processo de trabalho dos residentes, individual e coletivamente.

$\mathrm{Na}$ esfera política, o SIREMU tem contribuído significativamente ao produzir informações que possibilitam apresentar claramente as contribuições que a RMSF traz ao Sistema Saúde Escola, evidenciando dados sobre ações e atendimentos que suprem demandas locais, bem como aponta elementos para reflexões nas práticas e nos cenários de atuação dos profissionais. Com tais informações, o diálogo com gestores e Conselho Municipal de Saúde, acerca do retorno para o investimento feito na RMSF, no município, fica mais preciso e objetivo.

Para disseminação e fortalecimento do SIREMU, a cada nova turma da RMSF são realizadas sistematicamente algumas oficinas teórico-práticas, visando sensibilizar, vivenciar e refletir sobre a importância do Web SIREMU. Tais oficinas envolvem docentes e discentes e possibilitam ainda, a qualificação do Sistema, a partir das análises tecidas, trazendo importantes produtos, como a construção do instrutivo norteador, que orienta os profissionais quanto à operacionalização do Sistema (fluxos e preenchimento de fichas). 
Desta forma, compreendemos que o SIREMU encontra-se em permanente processo de aperfeiçoamento, agregando contribuições dos diversos atores envolvidos em sua efetivação (aspectos técnicos, pedagógicos e administrativos). No ano de 2012 ocorreu a ampla avaliação e reformulação da plataforma com seus fluxos, cujas alterações foram validadas pelo corpo docente e discente da RMSF, bem como pela direção da EFSFVS.

O suporte técnico, político e pedagógico para manutenção do SIREMU é assegurado pela Secretaria de Saúde de Sobral, através da EFSFVS. A sustentabilidade do Web SIREMU está associada à opção político-pedagógica vigente no Sistema Saúde Escola de Sobral, voltada para a inovação de práticas e saberes, os quais produzam conhecimentos, transformem práticas e contribuam para a qualificação da atenção à saúde no município. A condução político-pedagógica por profissionais da EFSFVS assegura a coerência com os princípios condutores da instituição, imprimindo aos processos relacionados ao SIREMU um caráter dialógico e participativo, pautado na educação permanente em saúde.

A Educação Permanente, aliás, baseia-se na aprendizagem significativa e na reflexividade das práticas reais em ação na rede de serviços, portanto, na problematização da realidade. (BRASIL. MINISTÉRIO DA SAÚDE, 2009) Visa compreender se a educação pelo trabalho contribui no "processo de reflexão que busca revelar o significado do que se fez, possibilitando, assim, repensar as experiências sob nova ótica." (FEUERWERKER et al., 2000)

O pressuposto de contínua ressignificação de práticas e experiências favorece a atuação do SIREMU, no sentido de contribuir para a produção de relatórios e análises que sejam o esteio para a gestão do programa de RMSF, bem como direcionem outros processos formativos desenvolvidos pela EFSFVS. Espera-se também que, em outra instância, o SIREMU possa contribuir na orientação da implantação, acompanhamento e avaliação do modelo de atenção à saúde e dos serviços existentes, considerando que as ações desenvolvidas pelos profissionais residentes entrelaçam-se às práticas profissionais na ESF e sinalizam importantes elementos de análise nesse contexto.

\section{Algumas considerações}

O trabalho na saúde, ou o chamado "trabalho vivo em ato" interage com fatores externos que o influenciam e são por ele influenciados, possibilitando interações com variadas tecnologias em saúde (leves, leve-duras ou duras). Os caminhos que perpassam a qualificação dos modos de produzir o cuidado em saúde, cada vez mais apontam para a formação dos profissionais, seja na graduação, na pós-graduação, ou nos serviços do SUS, na perspectiva da educação permanente.

No contexto da formação profissional para o SUS, a RMSF emerge como estratégia de formação em serviço que possibilita a vivência interdisciplinar e interprofissional, sobretudo por não se restringir a aspectos teóricos, agregando a vivacidade do processo de (re)construir saberes a partir da prática, culminando com a produção de tecnologias que aprimoram as formas de cuidar no SUS.

O SIREMU, enquanto tecnologia produzida pela RMSF, em Sobral, tem apresentado significativos resultados, tais como: redefinição de estratégias pedagógicas e de gestão na RMSF; ampliação das ações de colaboração interprofissional; maior articulação com a rede de 
cuidados; definição de um diagnóstico da formação a partir das realidades dos territórios de atuação dos residentes; estímulo à produção de práticas de cuidado na Estratégia Saúde da Família, a partir da problematização do processo de trabalho dos profissionais.

Reconhecemos, no SIREMU, a condição de evidenciar fragilidades e potencialidades, fomentando a (re)significação das práticas e, neste sentido, inferimos que sua contribuição deve ir além de qualificar a formação e o acompanhamento pedagógico dos residentes multiprofissionais. Acreditamos, portanto, que sua essência pode despertar contribuições similares em outros processos de educação em saúde, tanto no âmbito de Sobral, quanto nos diversos cenários do SUS existentes em todo o Brasil.

\section{Referências}

BRASIL. Ministério da Saúde. Revista Brasileira de Saúde da Familia. Ano II, N 5, p.10-11, 2002.

Trabalhadores de saúde e a saúde de todos os brasileiros: práticas de trabalho, gestão, formação e participação. Documentos preparatórios para a 3 a Conferência Nacional de Gestão do Trabalho e da Educação na Saúde. Brasília, 2005.

BRASIL. Ministério da Saúde. Secretaria de Gestão do Trabalho e da Educação na Saúde. Departamento de Gestão da Educação em Saúde. Política Nacional de Educação Permanente em Saúde. Brasília: Ministério da Saúde, 2009.
CECIM, R.B. "Ligar gente, lançar sentido: onda branda da guerra" a propósito da invenção da residência multiprofissional em saúde. Revista Interface (Botucatu) [online]. v.13, n.28, p. 233-235, 2009.

CHAGAS, M.I.O. Construção e Validação de indicadores de efetividade de formação nos programas de residência multiprofissional em saúde da família. Mimeo. Sobral, 2012.

FEUERWERKER, L.C.M.; SENA, R.R. Interdisciplinaridade, trabalho multiprofissional e em equipe: sinônimos? Como se relacionam e o que têm a ver com a nossa vida? Revista Olho Mágico, Londrina, v. 5, n. 18, p. 5-6, mar. 1999.

FEUERWERKER, L.C.M.; COSTA, H.O.G.; BARBOSA, N.; KHALIL, M.E. O processo de construção e de trabalho da Rede UNIDA. Revista Saúde em Debate. Rio de Janeiro, v.24, n.55, p.92-103, maio/ago, 2000.

FURTADO, J.P. Equipes de referência: arranjo institucional para potencializar a colaboração entre disciplinas e profissões. Revista Interface. v.11, n.22, p.239-55, mai/ago 2007.

GIL, C.R.D. Formação de recursos humanos em saúde da família: paradoxos e perspectiva. Cadernos de Saúde Pública, Rio de Janeiro, v.21, n.2, p.490-498, mar-abr/2005.

MERHY, E.E. A perda da dimensão cuidadora na produção da saúde uma discussão do modelo assistencial e da intervenção no seu modo de trabalhar a assistência. In: MERHY, E.E. Sistema Único de Saúde em Belo Horizonte Reescrevendo o Público. São Paulo: Xamã, 1998. 
NASCIMENTO, D.D.G.; OLIVEIRA, M.A.C. Competências profissionais e o processo de formação na residência multiprofissional em Saúde da Família. Revista Saúde e Sociedade. São Paulo, v.19, n.4, p.814-827. 2010.

SILVA, M.M.P. Efetividade da Residência Multiprofissional em Saúde da Família: uma análise a partir do quadrilátero da formação para a área da saúde. Fortaleza. Dissertação [Mestrado em Ensino na Saúde] - Universidade Estadual do Ceará; 2014.

\section{SOBRE OS AUTORES}

Adriano Ferreira Martins: Enfermeiro, Mestre em Saúde Pública (UFC), Especialista em Obstetrícia (UECE) e Especialista em Saúde da Família (UFC).Email: adrianoenfo@ hotmail.com

Ana Helena Araújo Bomfim Queiroz: Psicóloga, Doutoranda em Psicologia (UFRN). Mestre em Saúde Pública (UFC) e Especialista em Saúde Mental (UFC). Email: anahelenabqueiroz@gmail.com

Ana Karina de Sousa Gadelha: Psicóloga, Mestranda em Saúde da Família (UFC), Especialista com caráter de Residência Multiprofissional em Saúde da Família - Universidade Estadual Vale do Acaraú (UVA)/Escola de Formação em Saúde da Família Visconde de Sabóia (EFSFVS)/Secretaria Municipal de Saúde de Sobral/CE. Email: karina_gadelha@yahoo.com.br

André Luis Façanha da Silva: Professor de Educação Física, Mestre em Saúde de Família (UFC), Especialista com caráter de Residência Multiprofissional em Saúde da Família - Universidade Estadual Vale do Acaraú (UVA)/ Escola de Formação em Saúde da Família Visconde de Sabóia (EFSFVS)/Secretaria Municipal de Saúde de Sobral/ CE. Preceptor de Educação Física da RMSF/EFSFVS. Email: andre_facanha@hotmail.com 
Andréa Carvalho Araújo Moreira: Enfermeira, Mestre em Saúde Pública pela Universidade Federal do Ceará (UFC). Email: dreamoreira@yahoo.com.br

Bráulio Nogueira de Oliveira: Professor de Educação Física, Mestrando em Saúde Coletiva (PPGSC/UECE), Especialista em Saúde do Idoso (UECE), Especialista com caráter de Residência Multiprofissional em Saúde da Família - Universidade Estadual Vale do Acaraú (UVA)/Escola de Formação em Saúde da Família Visconde de Sabóia (EFSFVS)/Secretaria Municipal de Saúde de Sobral/CE. Email: brauliono08@hotmail.com

Cilene Maria Freitas: Enfermeira, Mestre em Saúde Pública (UECE), Preceptora de Educação Permanente da Escola de Formação em Saúde da Família Visconde de Sabóia (EFSFVS). Email: cilenefreit@yahoo.com.br

Danilo Sampaio Souza: Fonoaudiólogo, Especialista com caráter de Residência Multiprofissional em Saúde da Família - Universidade Estadual Vale do Acaraú (UVA)/Escola de Formação em Saúde da Família Visconde de Sabóia (EFSFVS)/ Secretaria Municipal de Saúde de Sobral/CE, Especialista em Audiologia (UNIFOR). Email: danilosampaio16@hotmail. com

Diana Cris Macedo Rodrigues: Nutricionista, Mestre em Saúde Pública, Especialista com caráter de Residência Multiprofissional em Saúde da Família - Universidade Estadual Vale do Acaraú (UVA)/Escola de Formação em Saúde da Família Visconde de Sabóia (EFSFVS)/Secretaria Municipal de Saúde de Sobral/CE. Email: diamaiscedo@ hotmail.com

Elyudienne Andressa Silva Alves: Nutricionista, Especialista com caráter de Residência Multiprofissional em Saúde da Família - Universidade Estadual Vale do Acaraú (UVA)/ Escola de Formação em Saúde da Família Visconde de Sabóia (EFSFVS)/Secretaria Municipal de Saúde de Sobral/ CE. Email: andressaalves_nutri@hotmail.com
Fátima Café Ribeiro dos Santos: Nutricionista, Especialista com caráter de Residência Multiprofissional em Saúde da Família - Universidade Estadual Vale do Acaraú (UVA)/ Escola de Formação em Saúde da Família Visconde de Sabóia (EFSFVS)/Secretaria Municipal de Saúde de Sobral/ CE. Email: fatimacafe@hotmail.com

Felipe Wachs: Professor de Educação Física, Mestre e Doutor em Ciências do Movimento (UFRGS), Especialista em caráter de Residência Multiprofissional em Saúde Mental (ESP-RS), Especialista em Pedagogias do Corpo e da Saúde (UFRGS). Email: felipewachs@gmail.com

Flávia Pinheiro da Costa: Enfermeira, Especialista com caráter de Residência Multiprofissional em Saúde da Família - Universidade Estadual Vale do Acaraú (UVA)/ Escola de Formação em Saúde da Família Visconde de Sabóia (EFSFVS)/Secretaria Municipal de Saúde de Sobral/ CE. Email: flaviap_costa@hotmail.com

Francisca Lopes de Souza: Assistente social, Mestre em Saúde da Família (UFC), Coordenadora de Ensino da Escola de Formação em Saúde da Família Visconde de Sabóia (EFSFVS).Email:fran.lopesdesouza@gmail.com

Gláucia Almeida Mapurunga de Paiva: Enfermeira, Especialista com caráter de Residência Multiprofissional em Saúde da Família - Universidade Estadual Vale do Acaraú (UVA)/Escola de Formação em Saúde da Família Visconde de Sabóia (EFSFVS)/Secretaria Municipal de Saúde de Sobral/ $\mathrm{CE}$, Especialista em Saúde Pública (ISEUB), Especialista em Educação Profissional na área da Saúde: Enfermagem (FIOCRUZ). Email: glauciamapurunga@yahoo.com.br

Hermínia Maria Sousa da Ponte: Enfermeira. Mestre em Saúde Pública (UECE). Email: herminiaponte@yahoo.com. br 
Igor Carneiro Gomes: Professor de Educação Física, Especialista com caráter de Residência Multiprofissional em Saúde da Família - Universidade Estadual Vale do Acaraú (UVA)/Escola de Formação em Saúde da Família Visconde de Sabóia (EFSFVS)/Secretaria Municipal de Saúde de Sobral/CE. Email: igoreducacaosaude@gmail.com

Janayna dos Santos Moura: Nutricionista, Especialista com caráter de Residência Multiprofissional em Saúde da Família - Universidade Estadual Vale do Acaraú (UVA)/Escola de Formação em Saúde da Família Visconde de Sabóia (EFSFVS)/Secretaria Municipal de Saúde (SMS), Sobral/CE. Email: janayna-moura@hotmail.com

Léo Barbosa Nepomuceno: Psicólogo, Doutor em Saúde Coletiva (UFC), Mestre em Psicologia (UFC), Especialista com caráter de Residência Multiprofissional em Saúde da Família - Universidade Estadual Vale do Acaraú (UVA)/ Escola de Formação em Saúde da Família Visconde de Sabóia (EFSFVS)/Secretaria Municipal de Saúde de Sobral/ CE, Docente da UFC. Email: leobnepomuceno@hotmail. com

Liduina Joyce Prado Linhares: Fisioterapeuta, Especialista com caráter de Residência Multiprofissional em Saúde da Família - Universidade Estadual Vale do Acaraú (UVA)/ Escola de Formação em Saúde da Família Visconde de Sabóia (EFSFVS)/Secretaria Municipal de Saúde de Sobral/ CE, Especialista em Saúde Pública (UECE). Email: lidujoyce@ hotmail.com

Manoel Artur Ferreira Sousa Filho: Professor de Educação Física, Especialista com caráter de Residência Multiprofissional em Saúde da Família - Universidade Estadual Vale do Acaraú (UVA)/Escola de Formação em Saúde da Família Visconde de Sabóia (EFSFVS)/Secretaria Municipal de Saúde de Sobral/CE. Email: mafsfef@gmail. com
Márcia Maria Santos da Silva: Assistente Social, Mestre em Ensino na Saúde (UECE). Especialista com caráter de Residência Multiprofissional em Saúde da Família Universidade Estadual Vale do Acaraú (UVA)/Escola de Formação em Saúde da Família Visconde de Sabóia (EFSFVS)/ Secretaria Municipal de Saúde de Sobral/CE. Coordenadora da RMSF (EFSFVS). Email: marciamss@yahoo.com.br

Márcio Anderson Cardozo Paresque: Odontólogo, Mestre em Saúde da Família (UFC), Especialista com caráter de Residência Multiprofissional em Saúde da Família - Universidade Estadual Vale do Acaraú (UVA)/Escola de Formação em Saúde da Família Visconde de Sabóia (EFSFVS)/Secretaria Municipal de Saúde de Sobral/CE. Email: marcioparesque@gmail.com

Maria da Glória dos Santos Ribeiro: Psicóloga, Especialista com caráter de Residência Multiprofissional em Saúde da Família - Universidade Estadual Vale do Acaraú (UVA)/ Escola de Formação em Saúde da Família Visconde de Sabóia (EFSFVS)/Secretaria Municipal de Saúde de Sobral/ CE. Email: gloriasr8@gmail.com

Maria das Graças Sousa: Terapeuta Ocupacional, Especialista com caráter de Residência Multiprofissional em Saúde da Família - Universidade Estadual Vale do Acaraú (UVA)/Escola de Formação em Saúde da Família Visconde de Sabóia (EFSFVS)/Secretaria Municipal de Saúde de Sobral/CE. Email: gracinha_lumen@hotmail.com

Maria José Galdino Saraiva: Pedagoga, Mestre em Ensino na Saúde. Especialista em Gestão Pedagógica para Escolas Técnicas do SUS, Coordenadora Pedagógica do Núcleo de Educação Profissional da Escola de Formação em Saúde da Família Visconde de Sabóia (EFSFVS). Email: mariajosegaaldinosaraiva@gmail.com 
Maria Lidiany Tributino de Sousa: Psicóloga, Doutoranda em Saúde Coletiva (UECE), Mestre em Saúde da Família (UFC), Especialista com caráter de Residência Multiprofissional em Saúde da Família - Universidade Estadual Vale do Acaraú (UVA)/Escola de Formação em Saúde da Família Visconde de Sabóia (EFSFVS)/Secretaria Municipal de Saúde de Sobral/CE. Email: tribudiany@gmail.com

Maria Michelle Bispo Cavalcante: Enfermeira, Mestre em Saúde da Família (UFC), Especialista com caráter de Residência Multiprofissional em Saúde da Família - Universidade Estadual Vale do Acaraú (UVA)/Escola de Formação em Saúde da Família Visconde de Sabóia (EFSFVS)/Secretaria Municipal de Saúde de Sobral/CE. Email: michellebispoc@yahoo.com.br

Maria Rocineide Ferreira da Silva: Enfermeira, Doutora em Saúde Coletiva (UFC), Mestre em Saúde Pública (UECE), Docente da Universidade Estadual do Ceará (UECE). Email: rocineideferreira@gmail.com

Maria Socorro de Araújo Dias: Enfermeira, Doutora em Enfermagem (UFC), Mestre em Enfermagem (UFC). Especialista em Ativação Processos de Mudança na Formação em Saúde (Escola Nacional de Saúde Pública, ENSP), Docente da Universidade Estadual Vale do Acaraú, Diretora da Escola de Formação em Saúde da Família Visconde de Sabóia. Email: socorroad@gmail.com

Maristela Inês Osawa Vasconcelos: Enfermeira, Doutora em Enfermagem (UFC), Mestre em Enfermagem (UFC), Docente e Pró-Reitora de Extensão e Cultura da Universidade Estadual Vale do Acaraú. Email: miosawa@gmail.com

Odemir Pires Cardoso Júnior : Fisioterapeuta, Especialista com caráter de Residência Multiprofissional em Saúde da Família - Universidade Estadual Vale do Acaraú (UVA)/ Escola de Formação em Saúde da Família Visconde de Sabóia (EFSFVS)/Secretaria Municipal de Saúde de Sobral/ CE. Email: odemirjunior@yahoo.com.br

\section{Publicações da Editora Rede UNIDA}

\section{Séries}

Clássicos da Saúde Coletiva

Micropolítica do Trabalho e o Cuidado em Saúde

Arte Popular, Cultura e Poesia

Interlocuções: Práticas, Experiências e Pesquisas em Saúde

\section{Atenção Básica e Educação na Saúde}

Saúde Coletiva e Cooperação Internacional

Vivências em Educação na Saúde

Cadernos da Saúde Coletiva

Economia da Saúde e Desenvolvimento Econômico

\section{Saúde \& Amazônia}

\section{Periódicos}

Revista Saúde em Redes

Revista Cadernos de Educação, Saúde e Fisioterapia

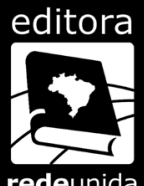

redeunida

www.redeunida.org.br 